This report was prepared as an account of work sponsored by an agency of the United States Government. Neither the United States Government nor any agency thereof, nor any of their employees, makes any warranty, express or implied, or assumes any legal liability or responsibility for the accuracy, completeness, or usefulness of any information, apparatus, product, or process disclosed, or represents that its use would not infringe privately owned rights. Reference herein to any specific commercial product, process, or service by trade name, trademark, manufacturer, or otherwise does not necessarily constitute or imply its endorsement, recommendation, or favoring by the United States Government or any agency thereof. The views and opinions of authors expressed herein do not necessarily state or reflect those of the United States Government or any agency thereof.

\title{
ASSESSMENT OF ENVIRONMENTAL PROBLEMS ASSOCIATED WITH INCREASED ENHANCED OIL RECOVERY IN THE UNITED STATES: 1980-2000
}

\author{
E. Kaplan, M. Garrell, ${ }^{1}$ B. Royce,
} E.F. Riedel, ${ }^{2}$ and J. Sathaye ${ }^{3} \quad$ BNL-- 51528

DE8 3016770

BHL 51528

UC-92a

(Petroleum and Natural GasProduction - TIC-4500]

January 1983

1. Adelphi University, Garden City, New York 11530

2. Formerly at Pacific Northwest Laboratory, Richland, Washington 99352

3. Lawrence Berkeley Laboratory, Berkeley, California 94720

\author{
Prepared for \\ DR. GEORGE J. ROTARIU \\ OFFICE OF ENVIRONMENTAL PROGRAMS \\ UNITED STATES DEPARTMENT OF ENERGY
}

\author{
DIVISION OF ENERGY AND ECONOMIC ANALYSIS \\ NATIONAL CENTER FOR ANALYSIS OF ENERGY SYSTEMS \\ DEPARTMENT OF ENERGY AND ENVIRONMENT
}

\section{BROOKHAVEN NATIONAL LABORATORY \\ ASSOCIATED UNIVERSITIES, INC.}

UNDER CONTRACT NO. DE-AC02-76CH00016 WITH THE 


\section{DISCLAIMER}

Portions of this document may be illegible in electronic image products. Images are produced from the best available original document. 


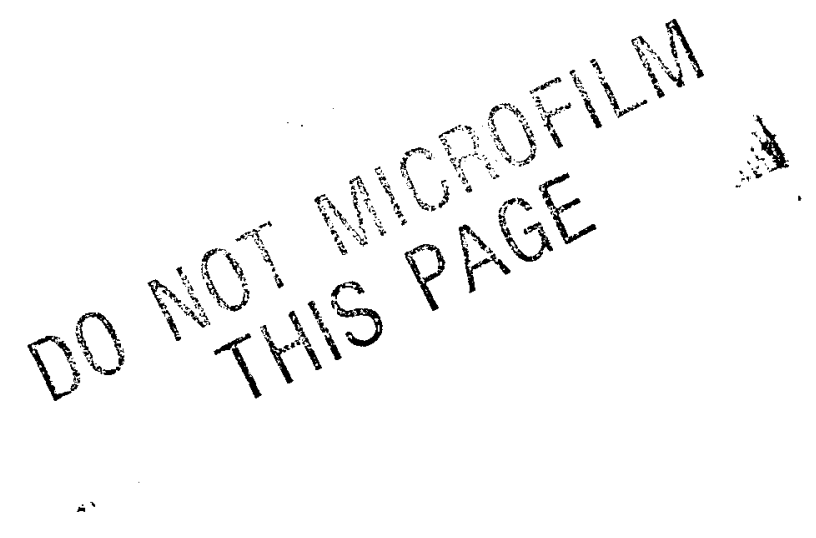

DISCLAIMER

This report was prepared as an account of work sponsored by an agency of the United States Government. Neither the United States Government nor any agency thereof, nor any of their employees, nor any of their contractors, subcontractors, or their employees, makes any warranty, express or implied, or assumes any legal liability or responsibility for the accuracy, completeness, or usefulness of any information, apparatus, product, or process disclosed, or represents that its use would not infringe privately owned rights. Reference herein to any specific commercial product, process, or service by trade name, trademark, manufacturer, or otherwise, does not necessarily constitute or imply its endorsement, recommendation, or favoring by the United States Government or any agency, contractor or subcontractor thereof. The views and opinions of authors expressed herein do not necessarily state or reflect those of the United States Government or any agency, contractor or subcontractor thereof.

Printed in the United States of America Available from

National Technical Information Service

U.S. Department of Commerce

5285 Port Royal Road

Springfield, VA 22161

NTIS price codes:

Printed Copy: A08; Microfiche Copy: A01

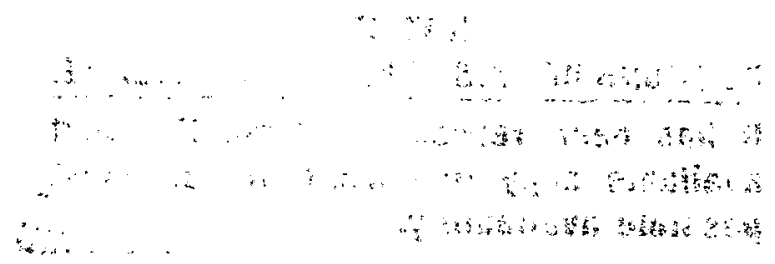


The U.S. Department of Energy, Office of Environmental Assessments, Office of Environmental Protection, Safety and Emergency Preparedness, has been conducting technology assessments of the evolving energy technologies to evaluate as quantitatively as possible the potential environmental, health, and socioeconomic impacts of each technology as it moves towards commercialization. The assessments identify where further information is needed; provide an analysis of potential environmental, health, and socioeconomic consequences of each developing technology; and define research and development needed to ensure environmentally acceptable commerclalization. This report on enhanced oil recovery is such an assessment. 


\section{EXECUTIVE SUMMARY}

An assessment was performed of environmental problems associated with the commercialization of enhanced oil recovery (EOR) in the United States. of particular importancel were estimates of impact which might be expected during the next twenty years. This study involved participants from several national laboratories and was commissioned by the office of Environmental Programs, U.S. Department of Energy.

Estimates of U.S. EOR by the year 2000 were made on a county-by-county basis using information derived primarily from industrial sources. A fieldby-field scenario was produced with estimates of daily production from the EOR technology (or technologies) most likely to be employed at each site.

Water requirements and uncontrolled air emissions from well vents and steam generators were estimated for each technology based upon available 1iterature. Estimates of best air emission control technologies were made using data for EOR steam generators actually in use, as well as control technologies presently available but used by other industries. Amounts of solid wastes were calculated for each air emission control technology. Estimates were also made of the heavy metal content of these solid wastes, particularly important insofar as these wastes may be classified as being hazardous and thus requiring special handling and disposal. The study also included environmental residuals which may be expected should coal be used instead of lean crude to produce steam for thermal EOR.

It was concluded that from an environmental prospective tertiary oil is preferable in many respects to shale ofl, coal and synfuels. Alternative sources of oil such as syncrude, new exploration, and primary production could cause far more environmental damage than incremental EOR. Future EOR in specific regions may be constrained because of environmental issues: air emissions, solid waste disposal, water availability, and aquifer contaminators. Competition for water and the scarcity of surface water or groundwater which are low in total diminutive solids will impede some EOR projects. Risks of groundwater contamination should be minimized particularly because of requirements of the Environmental Protection Agency's new underground injection control program.

A quantitative environmental assessment will require a complete and consistent data base for all fields for which EOR is planned out in which tertiary production is taking place. This is particularly true for EOR which will occur in Alaska or in offshore areas, where environments are fragile and where operating conditions are severe. 
Executive Summary.................................... iv

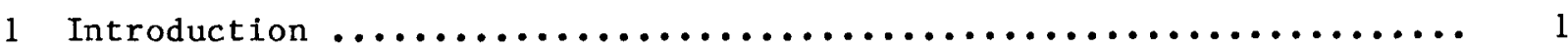

References...........................................

2 Resource Description and Production Scenarios.................. 5

2.1 Future Production................................... 5

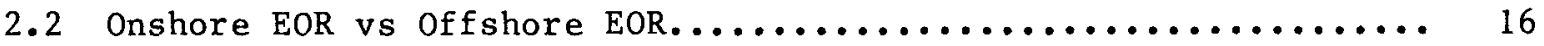

2.3 Alaskan EOR....................................... 16

References.......................................... 17

3 Current EOR Recovery Techniques............................. 19

3.1 Techniques........................................ $\ldots \ldots$

3.2 Chemical Recovery Methods............................. 20

3.2.1 Alkaline Flooding............................... 20

3.2 .2 Polymer Flooding................................ 20

3.2.3 Micellar-Polymer Flooding........................ 21

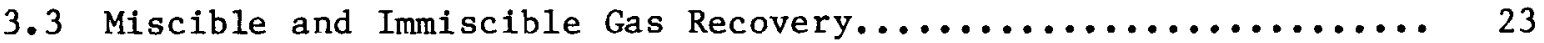

3.4 Thermal Recovery...................................... 25

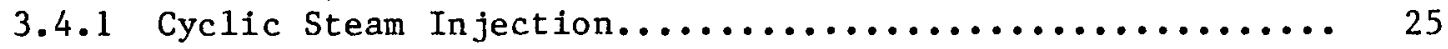

3.4 .2 Steam Drive................................... 26

3.4 .3 In Situ Combustion............................. 27

References........................................... 28

4 Potential Technological Advances.............................. . . 29

4.1 Downhole Steam Generation............................... 29

4.2 Fracture-Assisted Steam Technology (FAST) ................. 30

4.3 Other Advances In Steam Injection Methods.................. 30

4.4 Cheaper Carbon Dioxide Generation....................... 31

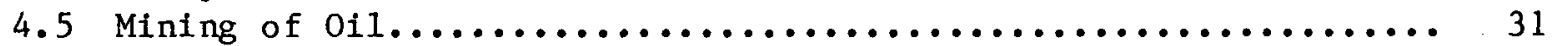

4.6 Advances in Polymer Research........................... 33

4.7 Microbial Enhanced $0 i 1$ Recovery (MEOR) .................... 33

4.8 Tar Production by Radio Frequency Heating................... 34

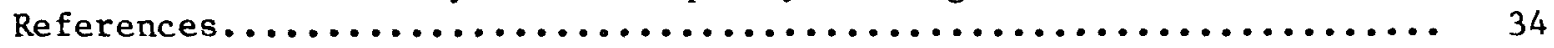

5 Assessment of Potential Environmental Impacts and Problems........ 37

5.1 Introduction....................................... 37

5.2 The Problems....................................... 37

5.3 Regional Environmental Issues........................... 38

5.4 Mitigation of Impacts: Controls and Regulations.............42

5.5 Scaling Impacts to Production Bases...................... 43

5.6 Water Impacts of Enhanced $0 i 1$ Recovery..................... 46

5.6 .1 Water Requirements.............................. 46

5.6 .2 Water Sources.................................. 49

5.6 .3 Water Quality................................. 52

5.6 .4 Groundwater Contamination........................ 62

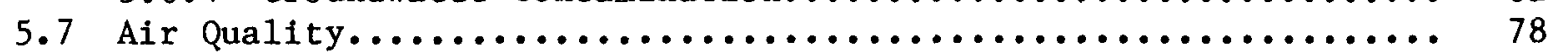

5.7 .1 Sources of Pollution.......................... 78

5.7 .2 Emission Controls............................ 71

5.7 .3 Regulations and Issues.......................... 90

5.7 .4 Scenario....................................... 95

5.7 .5 Conclusions.................................. 102 
5.8 Solid Waste Impacts.............................. 104

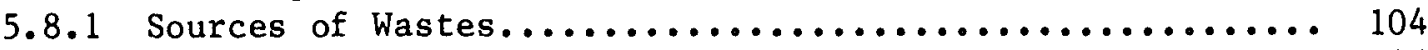

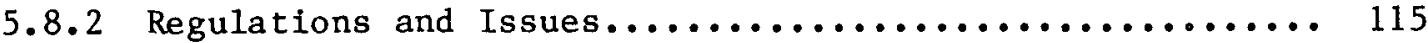

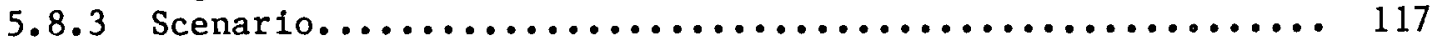

5.8 .4 Implications of Solid Wastes Scenario................ 119

References....................................... 120

6 Secondary Impacts: Land Use and Reclamation.................. 127

6.1 Land Use in Tertiary Recovery........................ 127

6.2 Land Requirements................................. 127

6.2 .1 Abandonment............................... 127

7 Conclusions....................................... 131

Appendix: Groundwater Contamination.......................... 133

Example 1: Short-Term Release.......................... 137

Example 2: Continuous Release.......................... 138

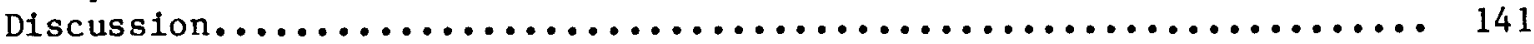

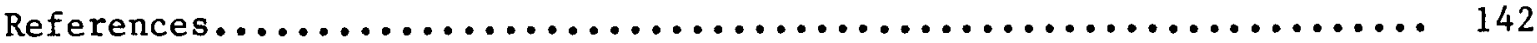

LIST OF TABLES

Table 2.1 Field-by-Field Production....................... 7

Table 2.2 Total Production by State....................... 12

Table 5.2 Water Requirements for EOR in bb1 of Water per bb1 of Tertiary 011 Produced........................ 47

Table 5.3 General Guidelines for Injection Water Quality.......... 55

Table 5.4 Water Consumption and Groundwater Overdraft............

Table 5.5 Relative Importance of Different Sources of Groundwater

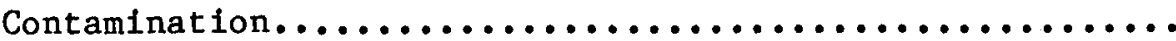

Table 5.6 Total Dissolved Solids in Oil Field Brine Samples in the

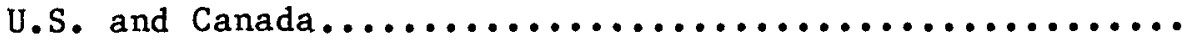

Table 5.7 Survey Chemicals Arranged by General Use in EOR......... 70

Table 5.8 Primary Drinking Water Quality Standards............... 74

Table 5.9 Noncompliance Summary, $1980 \ldots \ldots \ldots \ldots \ldots \ldots \ldots \ldots \ldots \ldots \ldots$

Table 5.10 Well Failure Summary, $1980 \ldots \ldots \ldots \ldots \ldots \ldots \ldots \ldots \ldots \ldots \ldots$

Table 5.11 Steam Generator Emission Rates...................... 80

Table 5.12 Uncontrolled Emission Factors for Major Pollutants from 50-MBtu/hr 011 Field Steam Generators............... 


\section{LIST OF TABLES continued}

Table 5.13 Particulate Composition (\% weight) from 50-MBtu/hr

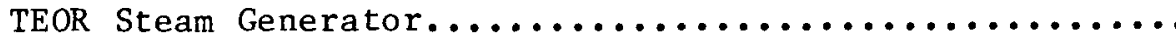

Table 5.14

Air Emissions from Compressors at Kern County, CA

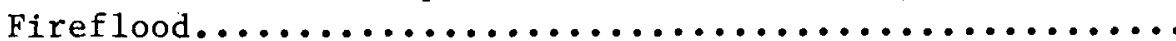

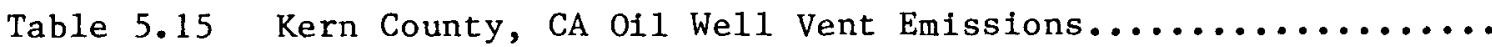

Table 5.16

Steam Generator Emissions.

Table 5.17

$\mathrm{NO}_{\mathbf{x}}$ Control Technologies.

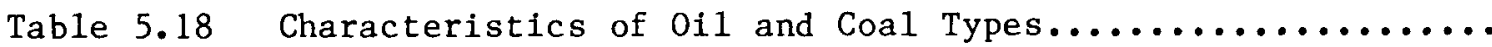

Table 5.19A

EPA 1979 Industrial Boiler FGD Survey Thermal EOR

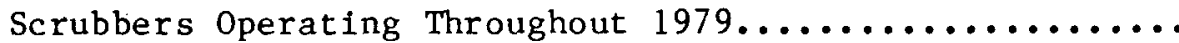

Table 5.19B EPA 1979 Industrial Boiler FGD Survey Thermal EOR Scrubbers Planned, Under Construction, or Started Up in 1979.

Table 5.20

National Ambient Air Quality Standards.

Table 5.21

New Source Performance Standards for Fossil-Fue1-Fired Steam Generators of More Than 250-MBtu/hour Heat Input

C.F.R. $\$ 60.40-46$.

Table 5.22

Guidelines for Significant Emission Rates.

Table 5.23

Air Emissions from EOR Environmental Scenario (Steamflood

Fields).

Table 5.24 Controlled Emissions From Steamflood Fields for

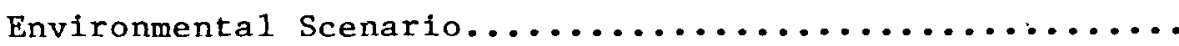

Table 5.25

Worst Case Estimates of Point Source Air Quality Impacts...

100

Table 5.26

Estimated Maximum 24-Hour Concentrations $\left(\mu \mathrm{g} / \mathrm{m}^{3}\right)$ at Distance 200 to $400 \mathrm{~m}$ from Controlled Emissions...

Table 5.27 Uncontrolled Air Emissions from EOR Environmental Scenario Using Coal to Generate Steam....................

Table 5.28

Types of Coa1 Which Might. Be Used in P1ace of 0t1 for Scenario TEOR.

Table 5.29 Controlled Emissions from EOR Environmental Scenario Using

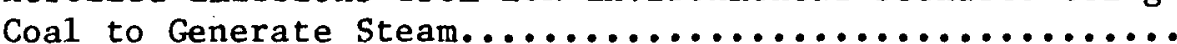

Table 5.30 Compositional Analysis of Drilling Mud Grade Barite (Barium Sulfate), Calcite (Calcium Carbonate), and Siderite (Iron Carbonate)....................... 


\section{LIST OF TABLES continued}

Table 5.31 Typical Drilling Mud Compositions (lb/bbl)............ 106

Table 5.32 Miscellaneous Materials Sometimes Used in Drilling Fluids.. 107

Table 5.33 Leachate Analysis of Experimental Mud Solidification

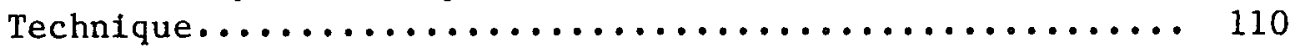

Table 5.34 Experimental Leachate Solidifications Process Using High Concentration of Heavy Metal Irons............... 110

Table 5.35 Comparison of FGD Systems on TEOR Oil-Fired Steam

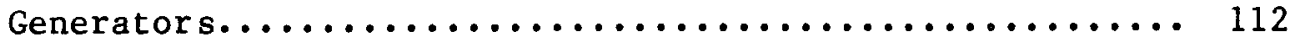

Table 5.36 Concentration Ranges for $\mathrm{B}$, Co, Na, Ni, Se, V, and Total Dissolved Solids in Four Different Samples of Liquid Wastes from FGD Systems Operating in Kern County....... 113

Table 5.37 Chemical Composition of Sludge from a Double-Alkali

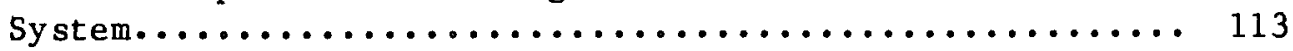

Table 5.38 Discharge of Major Constituents in the Waste from a Reference Atmospheric Fluidized-Bed Combustion Process... 115

Table 5.39 Oil Production Wastes Which May Be Controlled by Oklahoma Law.................................... 118

Table 5.40 Chemicals Which May Cause Tertiary Oil Production Wastes to be Controllable Under Oklahoma Law............. 118

Table 5.41 Solid Wastes from EOR Environmental Scenario (Steam Flood)

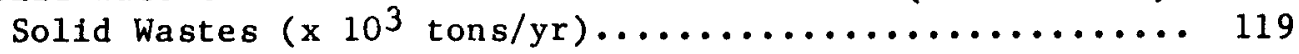

Table 6.1 Land Needs vs Recovery Techniques................. 128

Table 1 Proposed Water Quality Tolerances of Dissolved Solids for Livestock............................. 136

Table 2 Suggested Total Dissolved Solids Levels (mg/l) for Irrigation Waters......................... 136

Table $3 \quad$ Range of Values of Porosity $\ldots \ldots \ldots \ldots \ldots \ldots \ldots \ldots \ldots \ldots \ldots \ldots$

Table 4 Brine Concentration for Three Time Periods from Slug Release with an Initial Concentration of $50,000 \mathrm{mg} / \ell \ldots \ldots 138$

LIST OF FIGURES

Figure 2.1 Production, reserves, and residual oil in place......... 6

Figure 2.2 Fields and counties included in Scenarios A and B from

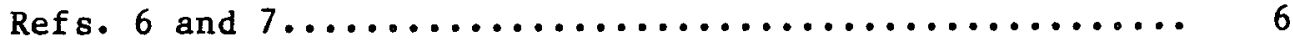




\section{LIST OF FIGURES continued}

F1gure 2.3 Windfall Profits $T a x$ and EOR.................... 15

Figure 3.1 Improvement of vertical sweep efficiency by polymer

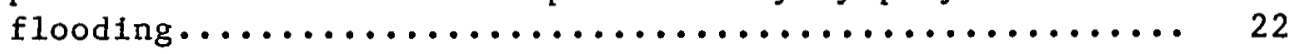

Figure $3.2 \quad$ Surfactant flooding process...................... 22

Figure 3.3 Schematic of the $\mathrm{CO}_{2}$ miscible process............... 24

Figure 3.4 Cyclic steam stimulation process................... 26

Figure 3.5 Schematic of the steamflooding process.............. 27

Figure 3.6 In situ combustion process - wet combustion........... 28

Figure 5.1 Regional EOR in petroleum provinces of the United States... 39

Figure 5.2 Fields where steamflood or cyclic steam or stean in combination with other methods is, has been, or is expected to be applied......................... 39

Figure 5.3 Fields where $\mathrm{CO}_{2}$ flood is, has been, or is expected to be

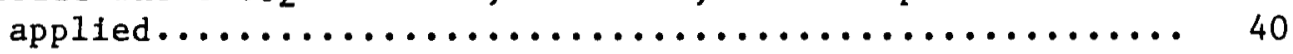

Figure 5.4 Fields where micellar-polymer flood is, has been, or is expected to be applied....................... 40

Figure 5.5 Fields where in situ combustion is, has been, or is expected to be applied...................... 41

Figure 5.6 Fields where polymer flood or caustic flood is, has been, or is expected to be applied................... 41

Figure 5.7 Choice of production figures for environmental scenarios... 45

Figure 5.8 Groundwater overdraft and related problems........... 47

Figure 5.15 Assessment subareas........................ 57

Figure 5.16 Groundwater overdraft within each subregion in millions of gallons/day in the year $1975 \ldots \ldots \ldots \ldots \ldots \ldots \ldots \ldots \ldots \ldots . \ldots \ldots$

Figure 5.17 The contamination of freshwater through bypass of the natural filter system........................... 64

Figure 5.18 The migration of petroleum products in soil \& groundwater.. 65

Figure 5.19 Residual oil saturation....................... 66

Figure 5.20 Results of Swiss experiments on oil saturation distribution

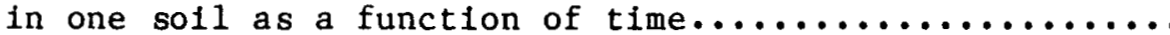




\section{LIST OF FIGURES continued}

Figure 5.21 Underground source drinking water contamination (USDW) by date of occurrence........................ 77

Figure 5.22 Options for managing wastes from FGD systems........... 111

Figure 1 Brine concentration from a slug release with an initial chlorides concentration of $50,000 \mathrm{mg} / \ell \ldots \ldots \ldots \ldots \ldots \ldots . \ldots 139$

Figure 2 Brine concentration 365 days after a continuous release of chlorides directly into the aquifier............ 140

Figure 3 Brine concentration 1095 days after a continuous release directly into the aquifier..................... 140

Figure 4 Brine concentration 1945 days after a continuous release directly into the aquifier..................... 141 


\section{INTRODUCTION}

From 1970 to the present, the Nation's known ofl reserves, which can be developed through conventional technology, have dwindled to some 27 billion barrels, 1 and domestic production has shrunk from a peak of $9.6 \mathrm{million}$ barrels a day ${ }^{2}(\mathrm{~b} / \mathrm{d})$ to the current level of $8.6 \mathrm{million} \mathrm{b} / \mathrm{d} .{ }^{3}$ Consequently, crude imports of $4.3 \mathrm{million} \mathrm{b} / \mathrm{d}$ and product imports of $1.6 \mathrm{million} \mathrm{b} / \mathrm{d}$ are required to bridge the gap between domestic production of $8.6 \mathrm{million} \mathrm{b} / \mathrm{d}$ and consumption of $15.6 \mathrm{million} \mathrm{b} / \mathrm{d} .3$

Because of the vulnerability of the U.S. to disruptive embargoes like the one instigated by the Organization of Petroleum Exporting Countries (OPEC) in 1973-1974, and because of the severe effects that a three- to four-fold increase in world oil prices in the past decade has had on the U.S. economy, every administration since 1970 has sought ways to increase domestic oil production. Increased exploration for primary sources, stimulation of synthetic fuels production, and increased production of ofl through enhanced recovery (tertiary) techniques have been the three principal means discussed by government and industry. The last is considered particularly attractive by many because it could produce as much as one-quarter to onethird of the 312 million barrels ${ }^{l}$ in place after conventional recovery has been exhausted. (For comparison, the unproven primary reserves on the whole 1.8-million-square-mile outer continental shelf of the U.S. are guessed to be substantially less than 35 billion barrels. ${ }^{4}$ )

The distinction between primary, secondary, and tertiary production, the last known as enhanced ofl recovery (EOR), is important. When a petroleum reservoir is first discovered, it is usually put on primary production. During primary production, ofl, gas, and other reservoir flufds flow through the reservoir when the in situ reservoir pressure is greater than the pressure in the wellbore. This pressure difference provides the driving energy of the reservolr. Driving energy can be supplied by the expansion of gas (free or solution), by water influx, or by gravity drainage. If this energy is Insufficient, artificial lift methods may be needed. Once the reservolr's natural energy is depleted, energy must be added to produce o11, and other recovery methods are required.

After reservolr pressures have become depleted by production, it is common to replace gas or water in the formation to help maintain or increase natural pressures. . This process is termed pressure maintenance. Either gas (alr, carbon dioxide, or natural gas). or water may be 1 injected for pressure maintenance. Both methods usually require the drilling of new wells. To be most efficient, groups of producers often work together so that the injection rates and pressures may be monitored for the entire reservolr. Th1s process is called unitization.

Secondary recovery methods are very similar to pressure maintenance techniques. They are also used when natural pressures have been depleted. However, instead of simply maintaining those pressures, secondary recovery methods actually replace declining natural pressures by repressuring a reservoir through the injection of water or gas. 011 recovery by a 
combination of primary and secondary recovery usually averages about $40 \%$ of the original oil in place.

Today, waterflooding is the most widely used secondary recovery technique. This procedure was first employed over 100 years ago but was not widespread until the late 1940 s and early 1950s. A common pattern for waterflooding is the five-spot; four injection wells are drilled forming a square with a single producing well at the center. The injection operation must be carefully controlled and monitored to maintain an even advance of the water front. When secondary recovery methods become ineffective, other techniques called tertiary, or enhanced, recovery methods may be applied. These methods, discussed in detail in Chapter 3, include: thermal recovery using steam or in situ combustion, chemical flooding with micellar-polymer, caustic, or polymer solutions, and miscible gas flooding, primarily with $\mathrm{CO}_{2}$.

Promise for boosted domestic production from EOR depends to a very large extent on economic factors. With oil costs ranging anywhere from $\$ 21$ to $\$ 39$ per barrel, 5 1.e., from $\$ 3.82$ to $\$ 7.09$ per million Btu in 1981 dollars, tertiary ofl is generally considered to be a costlier fuel than either coal or price-controlled natural gas. Hence, incentives programs like the now defunct Tertiary Incentives Program, administered by the U.S. Department of Energy (USDOE), through 1981; federal excise taxes like the Windfall Profits Tax currently in force; total decontrol of crude ofl, effected by the Reagan Administration in 1981; the tax status (currently under debate) of some of the heavier crudes recovered through thermal EOR; and proposed slashes in EOR research funds, e.g., from $\$ 15.5$ million in fiscal 1982 to $\$ 5.3$ million in fiscal $1983^{6}$ all can profound by affect production of tertiary oil in coming decades. Nevertheless, the Reagan Administration's National Energy Policy Plan predicts that by the year 2000 EOR will increase to some $1.8 \mathrm{million}$ $\mathrm{b} / \mathrm{d} 7,8$ from the current level of nearly 400 thousand $\mathrm{b} / \mathrm{d}$.

The environmental impacts of such dramatically increased EOR have been treated before in many documents, including studies by consultants, ${ }^{9}$ a Project Planning Document, 10 an Environmental Readiness Document, 11 and Environmental Development Plans, 12 but more quantitative estimates of environmental effects were requested by the USDOE, Offices of Energy Technology and the Environment, in 1979 (currently the Office of Environmental Programs). With that goal in mind, a group from three national laboratories, Brookhaven, Lawrence Berkeley, and Pacific Northwest, undertook this environmental assessment. In the course of gathering information for this report, the group invited participants from industry, private consulting companies, and government agencies, along with environmentalists, scientists, and engineers, to a DOE-sponsored workshop on "Enhanced 011 Recovery: Problems, Scenarios, and Risks," held in Bozeman, Montana, August 24-27, 1980.13 Many helpful suggestions and some useful information from that workshop have been incorporated into this document.

Projecting from industry figures for the 226 active projects listed in a 1980 survey conducted by the 011 and Gas Journal, 14 and from subsequent information in that publication as well as in Enhanced Recovery Week, this report derives production estimates for U.S. $\overline{E O R}$ by the year 2000 in two scenarios contained in Chapter 2. One scenario produces a result similar to the one found in the National Energy Policy Plan, while the other uses a 
lower number. Chapters 3 and 4 present brief discussions of current EOR techniques and anticipated technological advances.

Because the production scenarios in Chapter 2 are based on numbers for each field, it was possible to calculate environmental parameters on a fieldby-field of county-by-county basis simply through the application of scaling factors. This methodology is used in Chapter 5, the core of the report, which assesses environmental impacts and problems from increased EOR over the next 20 years. Chapter 6 on land use illustrates the impacts associated with the changes in production status of typical oil fields, i.e., going from primary and secondary to tertiary production. An appendix on aquifer contamination was added in order to augment the material in Chapter 5.

\section{REFERENCES}

1. T.M. Doscher, Enhanced Recovery of Crude 011, Am. Sci. 69, No. 2, 193-9 (1981).

2. Enhanced Oil Recovery Potential in the United States, Congress of the United States, Office of Technology Assessment 1978. Lib. Congr. No. 77-600063.

3. Newsletter, 0i1 Gas J., December 28, 1981.

4. M.T. Halbouty, Requirements for a strong domestic energy policy, 58th Ann. Mtg., Int. O11 Scouts Assoc., 1981.

5. Consultant gives gloomy EOR forecast, Enhanced Recovery Week, p. 5, May 11,1981 .

6. EOR research funds slowly disappear, Enhanced Recovery Week, December $21,1981$.

7. National Energy Policy Plan III, DOE 1981, p. 35.

8. J.H. Jennrich, Reagan's national energy policy anchored firmly in free market, 0il Gas J., pp. 97-100, July 27, 1981.

9. R. Beck, R. Shore, T. Scriven, and M. Lindquist, Potential Environmental Problems of Enhanced 011 and Gas Recovery Techniques, Energy Resources Co., EPA Report IERL-CI-706, April 1980.

10. E.C. Donaldson, Environmental Compliance for EOR, Project Planning Document - FY 1979, DOE, Div. of Fossil Fuel Extraction and Bartlesville Energy Technology Center.

11. Environmental Readiness Document - Enhanced Oil Recovery, DOE/ERD-0013, September 1978.

12. Environmenta1 Development P1an (EDP) - DOE/EDP-0024, May 1978; Enhanced O11 Recovery, DOE/EDP-0048, November 1979. 
13. E. Kaplan, M. Garrell, E.F. Riedel, and J. Sathaye, Proceedings of DOE/Office of the Environment Workshop on Enhanced Oil Recovery: Problems, Scenario, Risks, BNL 51406, 1980.

14. S.L. Matheny, Jr., EOR methods help ultimate recovery, $0 i 1$ Gas J., pp. 79-124, March 31, 1980. 
This chapter describes the tertiary oil target from which production scenarios are derived. Observations qualifying the scenarios are included along with a brief discussion of the need for detailed study of EOR from offshore and Alaskan reservoirs.

\subsection{FUTURE PRODUCTION}

Estimates for United States enhanced oil recovery (EOR) in coming decades vary so widelyl-5 that they frustrate planners at all levels. Pessimists, noting the conservatism of the petroleum industry and applying strict economics with front-end payoffs, calculate production in the range of 0.75 to 1.25 millions of barrels per day $(\mathrm{Mb} / \mathrm{d})$. Optimists, looking at approximately 300 billion barrels as a potential tertiary target (Figure 2.1), feel that three to four million barrels per day of production is well within grasp by the year 2000 .

Some of the pessimistic predictions were made in the mid-1970's, before OPEC prices reached the $\$ 30$ to $\$ 40$ per barrel level and before the Tertiary Incentives Program, the Windfall Profits Tax, and oil price decontrol changed the equations of American petroleum economics, but other pessimistic predictions are more recent. The high estimates, on the other hand, are generated from calculations that appear oversimplified and gloss over the difficulties of tertiary production. For example, if one-fourth the estimated 312 billion barrels of remaining oil in place (ROIP) in U.S. reservoirs could be recovered over a 40 year period, the predicted mean production would be approximately:

$$
\begin{aligned}
\frac{\text { ROIP }}{4} & \times \frac{1}{40 y r \times 365 \mathrm{~d} / \mathrm{yr}}=\frac{312 \times 10^{9}}{5.84 \times 10^{4}} \mathrm{~b} / \mathrm{d} \\
& =53.4 \times 10^{5} \mathrm{~b} / \mathrm{d} \\
& =5.34 \mathrm{Mb} / \mathrm{d} .
\end{aligned}
$$

In order to give a balanced picture, this report uses two scenarios which are based on estimates of field-by-field petroleum production. Both scenarios appear in Tables 2.1 and 2.2. All current recovery techniques, described in Chapter. 3, apply to the fields in the two scenarios. Locations of fields included in these scenarios are shown in Figure 2.2.

The first scenario, labeled $A$, is based on production from fields of interest to oil companies through 1981. These are fields which have been the subjects of tertiary pilots or studies, fields which were currently producing substantial amounts of tertiary oil, and fields which were sufficiently promising to merit planned pilots or fieldwide projects by 1981. Approximately 150 fields, described in the International Petroleum Encyclopedia 6 and the 0 il and Gas Journal, ${ }^{7}$ provided the starting point for Scenario $A$. 


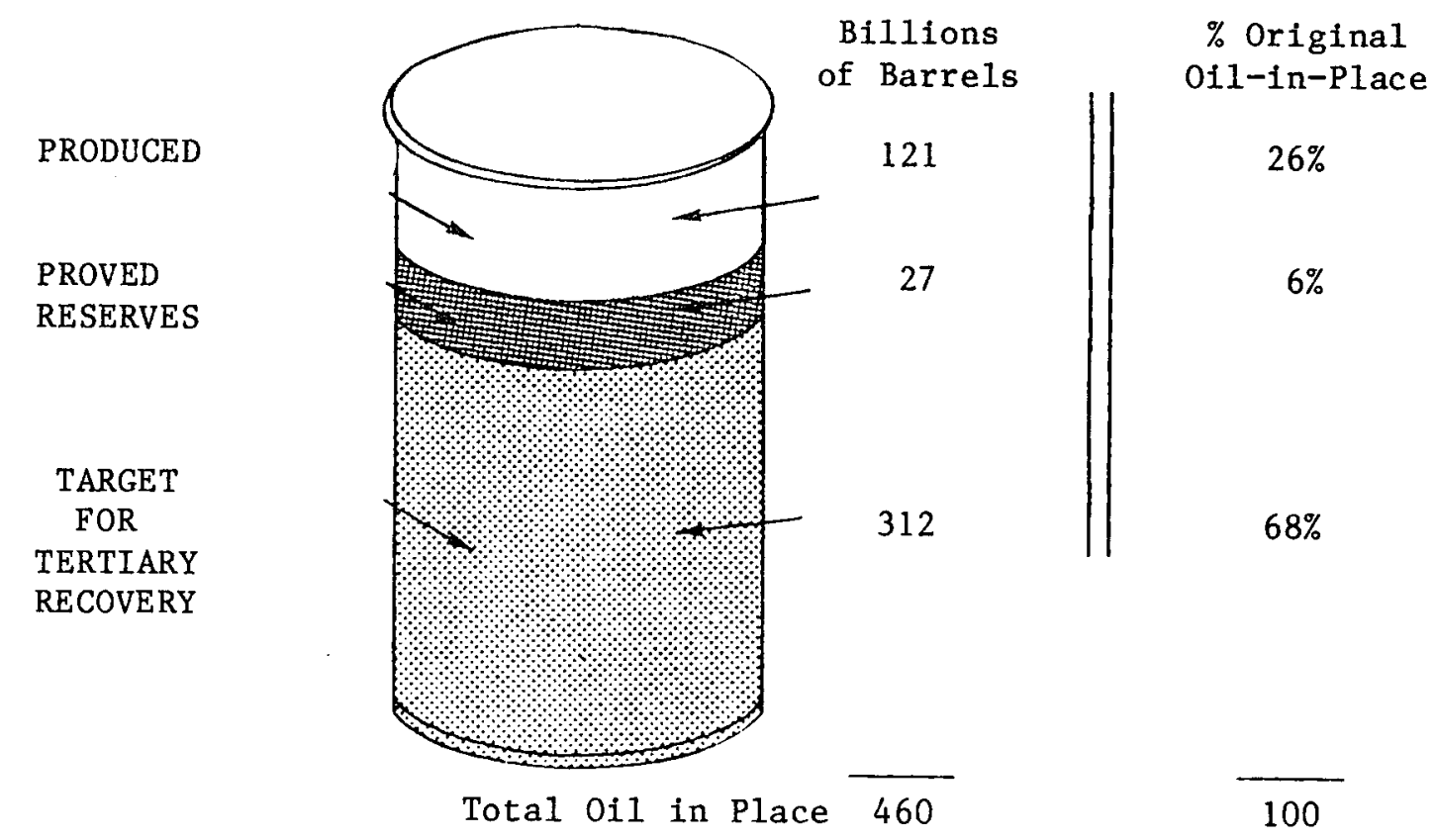

Figure 2.1. Production, reserves, and residual oil in place. Total U.S. (includes offshore and Alaska). (References 1 and 5.)

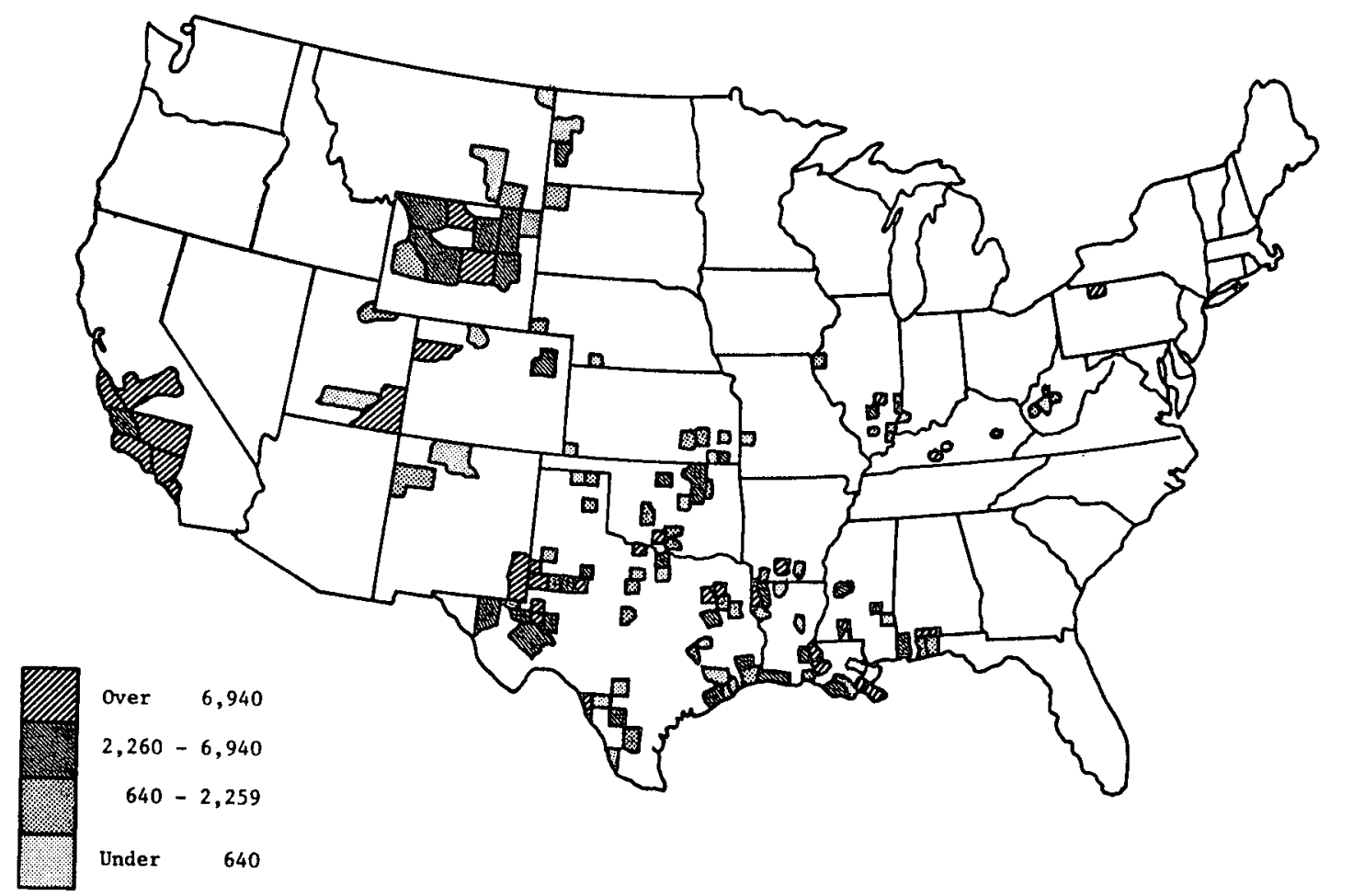

Figure 2.2. Fields and counties included in Scenarios A and B from references 6 and 7 . 
Table 2.1

Field-by-Field Production

\begin{tabular}{|c|c|c|c|c|c|}
\hline State & County & Field & EOR Method & $\begin{array}{l}\text { Scenario A } \\
\text { Est. Incre- } \\
\text { ment Pro- } \\
\text { duced over } \\
40 \text { years b/d }\end{array}$ & $\begin{array}{l}\text { Scenarlo B } \\
\text { Year } 2000 \\
\text { b/d Est. } \\
\text { Production }\end{array}$ \\
\hline $\begin{array}{l}\text { Al abama } \\
\text { (Flor ida) }\end{array}$ & $\begin{array}{l}\text { Escambia } \\
\text { (Escambia \& } \\
\text { Santa Rosa, } F L) \\
\text { Mobile }\end{array}$ & $\begin{array}{l}\text { Jay-Lit+le } e^{+} \\
\text {Escambria Creek } \\
\text { Citronelle }\end{array}$ & $\begin{array}{l}\mathrm{N}_{2} \\
\mathrm{CO}_{2}\end{array}$ & $\begin{array}{l}3,430 \\
4,110\end{array}$ & $<5,000$ \\
\hline Arkansas & $\begin{array}{l}\text { Bradley \& Union } \\
\text { Quachita \& Union } \\
\text { Lafayette }\end{array}$ & $\begin{array}{l}\text { Lick Creek }{ }^{+}+ \\
\text {Smackover* } \\
\text { Spirit Lake }\end{array}$ & $\begin{array}{l}\mathrm{CO}_{2} \\
\text { Steam } \\
\mathrm{CO}_{2}\end{array}$ & $\begin{array}{r}102 \\
34,700 \\
43\end{array}$ & 30,000 \\
\hline \multirow[t]{7}{*}{ Cal ifornia } & Fresno & Coal inga* & $\begin{array}{l}\text { Pol ymer } \\
\text { Steam }\end{array}$ & 135,000 & $\begin{array}{r}5,000 \\
10,000\end{array}$ \\
\hline & Kern & $\begin{array}{l}\text { Asphal to } \\
\text { Buena Vista Hil ls } \\
\text { South Belridge } \\
\text { Coles Levee } \\
\text { Cymric* } \\
\text { Edison* } \\
\text { Fruitvale* } \\
\text { Jasmint } \\
\text { Kern Bluff } \\
\text { Kern Front* } \\
\text { Kern River* } \\
\text { Lost Hills* } \\
\text { McKittrick* } \\
\text { Midway-Sunset* } \\
\text { Mount Poso* } \\
\text { Poso Creek } \\
\text { Round Mountain } \\
\text { Tejon-Grapevine }\end{array}$ & $\begin{array}{l}\text { Steam } \\
\text { Polymer } \\
\text { Steam } \\
\mathrm{CO}_{2} \\
\text { Steam } \\
\text { Steam } \\
\text { Steam } \\
\text { Steam } \\
\text { Steam } \\
\text { Steam } \\
\text { Steam } \\
\text { Steam } \\
\text { Steam } \\
\text { Steam } \\
\text { Steam } \\
\text { Steam } \\
\text { Steam } \\
\text { Steam }\end{array}$ & $\begin{array}{r}4,340 \\
4,450 \\
11,410 \\
7,530 \\
5,350 \\
20,000 \\
11,100 \\
239 \\
1,450 \\
22,400 \\
109,000 \\
10,800 \\
15,300 \\
130,000 \\
11,200 \\
9,930 \\
12,800 \\
4,220\end{array}$ & $\begin{array}{r}10,000 \\
100,000 \\
10,000 \\
10,000 \\
75,000 \\
<5,000\end{array}$ \\
\hline & Los Angeles & $\begin{array}{l}\text { Placerita } \\
\text { Torrence-Jough fin } \\
\text { Wayside Canyon } \\
\text { Wilmington* }\end{array}$ & $\begin{array}{l}\text { Steam } \\
\text { Caustic } \\
\text { Steam \& gas } \\
\text { Micel lar-polymer } \\
\text { Caustic } \\
\text { Steam }\end{array}$ & $\begin{array}{r}5,840 \\
207 \\
19 \\
263,000 \\
\text { or } \\
271,000\end{array}$ & $\begin{array}{l}<5,000 \\
<5,000 \\
100,000\end{array}$ \\
\hline & Monterey & $\begin{array}{l}\text { Lynch Canyon }{ }^{+} \\
\text {Marport } \\
\text { Paris Val ley } \\
\text { San Ardo* }\end{array}$ & $\begin{array}{l}\text { In situ } \\
\text { Steam } \\
\text { In situ } \\
\text { Steam }\end{array}$ & $\begin{array}{r}328 \\
8,260 \\
1,130 \\
22,100\end{array}$ & 45,000 \\
\hline & \rfloor$^{\text {Orange }}$ & $\begin{array}{l}\text { Brea Ol inda* } \\
\text { Huntington Beach* } \\
\text { Newport-Banning } \\
\text { Richfiel }{ }^{*} \\
\text { Yorba Linda }\end{array}$ & $\begin{array}{l}\text { Steam } \\
\text { Caustic } \\
\text { In situ } \\
\text { Polymer } \\
\text { Steam }\end{array}$ & $\begin{array}{r}26,200 \\
4,950 \\
9,110 \\
1,240 \\
12,700\end{array}$ & $<5,000$ \\
\hline & $\begin{array}{l}\text { San Luis Obispo } \\
\text { San Luis Obispo and } \\
\text { Santa Barbara }\end{array}$ & $\begin{array}{l}\text { Arroyo Grande } \\
\text { Guadal upe }\end{array}$ & $\begin{array}{l}\text { Steam } \\
\text { Steam }\end{array}$ & $\begin{array}{r}780 \\
4,940\end{array}$ & $<5,000$ \\
\hline & $\bigcup^{\text {Santa Barbara }}$ & $\begin{array}{l}\text { Brad ley Canyon } \\
\text { Casmal ia } \\
\text { Cat Canyon* } \\
\text { Santa Maria Valley } \\
\text { Orcutt }\end{array}$ & $\begin{array}{l}\text { Steam } \\
\text { Steam } \\
\text { Steam } \\
\text { Steam } \\
\text { Caust ic }\end{array}$ & $\begin{array}{r}6,600 \\
10,700 \\
31,700 \\
1,110\end{array}$ & $\begin{array}{r}<5,000 \\
10,000 \\
100,000 \\
<5,000\end{array}$ \\
\hline
\end{tabular}




\begin{tabular}{|c|c|c|c|c|c|}
\hline State & $\begin{array}{l}\text { County } \\
\text { or Parlsh }\end{array}$ & Fleld & EOR Method & $\begin{array}{l}\text { Scenario A } \\
\text { Est. Incre- } \\
\text { ment Pro- } \\
\text { duced over } \\
40 \text { years b/d } \\
\end{array}$ & $\begin{array}{l}\text { Scenario B } \\
\text { Year } 2000 \\
\text { b/d Est. } \\
\text { Production }\end{array}$ \\
\hline $\begin{array}{l}\text { California } \\
\text { (cont.) }\end{array}$ & $\downarrow^{\text {Ventura }}$ & $\begin{array}{l}\text { Oxnard } \\
\text { Santa Miguelito } \\
\text { Shiell's Canyon }\end{array}$ & $\begin{array}{l}\text { Steam } \\
\text { Polymer } \\
\text { Steam }\end{array}$ & $\begin{array}{r}4,890 \\
15 \\
4,080\end{array}$ & 50,000 \\
\hline Colorado & $\begin{array}{l}\text { Jackson } \\
\text { Rio Blanco } \\
\text { Washington }\end{array}$ & $\begin{array}{l}\text { McCal lum } \\
\text { Rangely } \\
\text { Plum Bush* }\end{array}$ & $\begin{array}{l}\mathrm{CO}_{2} \\
\mathrm{CO}_{2} \\
\text { In situ COFCAW }\end{array}$ & $\begin{array}{r}122 \\
44,000 \\
469\end{array}$ & \\
\hline Florida & Santa Rosa & 8lackjack Creek ${ }^{+}$ & Water/miscible gas & 342 & \\
\hline \multirow[t]{2}{*}{ IIIInois } & $\begin{array}{l}\text { Crawford } \\
\text { Crawford } \\
\text { Effingham \& } \\
\text { Fayette }\end{array}$ & $\begin{array}{l}\text { Robinson } \mathrm{M}-1^{+} \\
\text {Robinson } \mathrm{Al}^{-3} \\
\text { Louden* }\end{array}$ & $\begin{array}{l}\text { Micellar-polymer } \\
\text { In situ } \\
\text { Misclble gas } \\
\text { or } \\
\text { Micellar-polymer }\end{array}$ & $\begin{array}{r}164 \\
20 \\
6,770 \\
\text { or } \\
13,600\end{array}$ & $<5,000$ \\
\hline & $\begin{array}{l}\text { Franklin } \\
\text { Gallat in } \\
\text { Hancock \& McDonough } \\
\text { Lawrence } \\
\text { Marion } \\
\text { White }\end{array}$ & $\begin{array}{l}\text { Benton } \\
\text { East Inman } \\
\text { Colmar-PIymouth } \\
\text { Main Consol idated } \\
\text { Salem Consol lidated } \\
\text { Storm's Pool }^{+}\end{array}$ & $\begin{array}{l}\text { Micel lar-polymer } \\
\text { Micel lar-polymer } \\
\text { Micel lar-polymer } \\
\text { Micell lar-polymer } \\
\text { Micel lar-polymer } \\
\text { Polymer }\end{array}$ & $\begin{array}{r}2,020 \\
1,140 \\
125 \\
18,200 \\
3,420 \\
63\end{array}$ & $<5,000$ \\
\hline Indiana & Gibson & Griffin & Micel lar-polymer & 3,750 & \\
\hline \multirow[t]{2}{*}{ Kansas } & $\begin{array}{l}\text { Allen } \\
\text { Butler } \\
\text { Greenwood } \\
\text { Greenwood } \\
\text { Labette }\end{array}$ & $\begin{array}{l}\text { Bronson-Xeniat } \\
\text { El Doradot } \\
\text { Madison } \\
\text { Teeter } \\
\text { Chetopa }\end{array}$ & $\begin{array}{l}\text { Steam } \\
\text { Micel lar-polymer } \\
\text { Micel lar-polymer } \\
\text { Polymer } \\
\text { Mining, hot water, } \\
\text { \& surfactants }\end{array}$ & $\begin{array}{r}17 \\
1,790 \\
503 \\
165 \\
123\end{array}$ & $\begin{array}{l}<5,000 \\
<5,000\end{array}$ \\
\hline & $\begin{array}{l}\text { Montgomery } \\
\text { Morton }\end{array}$ & $\begin{array}{l}\text { Tyro Field Overlook } \\
\text { Berryman-Richtiel d }\end{array}$ & $\begin{array}{l}\text { Polymer } \\
\mathrm{CO}_{2}\end{array}$ & 137 & \\
\hline Kentucky & $\begin{array}{l}\text { Warren \& Butler } \\
\text { Hart } \\
\text { Lee }\end{array}$ & $\begin{array}{l}\text { Big Clifty } \\
\text { Bonnievllile } \\
\text { Big Sinking \& } \\
\text { Ida May }\end{array}$ & $\begin{array}{l}\mathrm{CO}_{2} \& \text { steam } \\
\mathrm{CO}_{2} \\
\mathrm{CO}_{2}\end{array}$ & $\begin{array}{r}4,790 \\
47 \\
1,370\end{array}$ & \\
\hline \multirow[t]{3}{*}{ Louisiana } & $\begin{array}{l}\text { Bossier } \\
\text { Caddo } \\
\text { Cameron } \\
\text { Clalborne } \\
\text { DeSoto } \\
\text { Iberla } \\
\text { lberville } \\
\text { LaFourche } \\
\text { LaSalle }\end{array}$ & $\begin{array}{l}\text { Bellevue } \\
\text { Caddo* } \\
\text { Black Bayou } \\
\text { Old Lisbon }{ }^{+} \\
\text {Bull Bayou } \\
\text { Weeks Island } \\
\text { White Castle } \\
\text { Clovelly } \\
\text { Nebo-Hemphill }\end{array}$ & $\begin{array}{l}\text { In situ } \\
\text { Steam } \\
\mathrm{HC} \text { miscible } \\
\text { Polymer } \\
\text { Polymer } \\
\mathrm{CO}_{2} \\
\text { Steam } \\
\text { Caustic } \\
\text { Caustic \& polymer }\end{array}$ & $\begin{array}{r}2,310 \\
31,600 \\
2,480 \\
410 \\
528 \\
1,780 \\
7,790 \\
55 \\
5\end{array}$ & $\begin{array}{l}<5,000 \\
<5,000\end{array}$ \\
\hline & P|aquemines & $\begin{array}{l}\text { Quarantine \& } \\
\text { West Bay }{ }^{+} \\
\text {(Offshore) } \\
\text { South Pass Block } \\
61^{+} \text {(Offshore) } \\
\text { South Pass Block } \\
27^{*} \text { (Offshore) }\end{array}$ & $\begin{array}{l}\mathrm{CO}_{2} \text { \& polymer } \\
\mathrm{HC}-\mathrm{misclble} \\
\text { Miscel lar-polymer }\end{array}$ & $\begin{array}{r}123 \\
500 \\
7,380\end{array}$ & \\
\hline & $\begin{array}{l}\text { Pointe Coupee } \\
\text { Sainte Landry } \\
\text { Terrebonne }\end{array}$ & $\begin{array}{l}\text { Fordochef } \\
\text { Port Barre } \\
\text { Bay Ste Elaine }\end{array}$ & $\begin{array}{l}\mathrm{N}_{2} \\
\mathrm{Steam} \\
\mathrm{CO}_{2}\end{array}$ & $\begin{array}{l}2,030 \\
5,250 \\
3,120\end{array}$ & $<5,000$ \\
\hline
\end{tabular}




\begin{tabular}{|c|c|c|c|c|c|}
\hline \multicolumn{6}{|c|}{ Table 2.1 cont inued } \\
\hline State & County & Field & EOR Method & $\begin{array}{l}\text { Scenario A } \\
\text { Est. Incre- } \\
\text { ment Pro- } \\
\text { duced over } \\
40 \text { years b/d }\end{array}$ & $\begin{array}{l}\text { Scenar io B } \\
\text { Year } 2000 \\
\text { b/d Est. } \\
\text { Product ion }\end{array}$ \\
\hline Mississippi & $\begin{array}{l}\text { Jasper } \\
\text { Lincoln } \\
\text { Pike } \\
\text { Wayne } \\
\text { Yazoo }\end{array}$ & $\begin{array}{l}\text { West He idel berg* } \\
\text { Mal lall leu } \\
\text { Little Creek* } \\
\text { West Yellow Creek* } \\
\text { Tinsley }\end{array}$ & $\begin{array}{l}\text { In situ } \\
\mathrm{CO}_{2} \\
\mathrm{CO}_{2} \\
\mathrm{Pol}_{\text {ymer }} \\
\mathrm{CO}_{2}\end{array}$ & $\begin{array}{r}4,840 \\
3,700 \\
889 \\
210 \\
3,010\end{array}$ & $<5,000$ \\
\hline Missouri & Vernon & Cheroke ${ }^{+}$ & $\mathrm{N}_{2}, \mathrm{CO}_{2} \&$ steam & 60 & \\
\hline Montana & $\begin{array}{l}\text { Powder River } \\
\text { Rosebud } \\
\text { Sheridan }\end{array}$ & $\begin{array}{l}\text { Bell Creek }{ }^{+} \\
\text {Rosebud (Sawyer) } \\
\text { Raymond }\end{array}$ & $\begin{array}{l}\text { Micel lar-polymer } \\
\text { Caustic } \\
\mathrm{Pol}_{\text {ymer }} \\
\mathrm{CO}_{2}\end{array}$ & $\begin{array}{r}1,500 \\
17 \\
5 \\
46\end{array}$ & $<5,000$ \\
\hline Nebraska & $\begin{array}{l}\text { Hitchcock } \\
\text { Kimball }\end{array}$ & $\begin{array}{l}\text { Dry Creek } \\
\text { Sloss }\end{array}$ & $\begin{array}{l}\text { Caust lc } \\
\text { Micel lar-pol ymer }\end{array}$ & $\begin{array}{r}21 \\
832\end{array}$ & $<5,000$ \\
\hline New Mexico & $\begin{array}{l}\text { Lea } \\
\text { Lea } \\
\text { McKinley } \\
\text { Rio Ariba }\end{array}$ & $\begin{array}{l}\text { North El Mar }{ }^{+} \\
\text {Mal jamar* } \\
\text { Lower Hospah } \\
\text { Puerto Chiqui to } \\
\text { Mancos }\end{array}$ & $\begin{array}{l}\mathrm{CO}_{2} \\
\mathrm{CO}_{2} \\
\text { In situ } \\
\text { Caustic }\end{array}$ & $\begin{array}{r}34 \\
6,810 \\
205 \\
27\end{array}$ & $\begin{array}{l}<5,000 \\
<5,000\end{array}$ \\
\hline North Dakota & $\begin{array}{l}\text { Billings, Dunn \& } \\
\text { McKenzie } \\
\text { McKenzie }\end{array}$ & $\begin{array}{l}\text { Little Knife } \\
\text { Charlson* }\end{array}$ & $\begin{array}{l}\mathrm{CO}_{2} \\
\mathrm{HC}-\mathrm{miscible} \& \\
\text { water }\end{array}$ & $\begin{array}{r}3,970 \\
638\end{array}$ & \\
\hline Oklahoma & $\begin{array}{l}\text { Caddo } \\
\text { Caddo } \\
\text { Creek } \\
\text { Garfield } \\
\text { Garvin } \\
\text { Garvin } \\
\text { Lincoln } \\
\text { Osage } \\
\text { Carter } \\
\text { Sfephens } \\
\downarrow \\
\text { Tulsa \& Wagoner }\end{array}$ & $\begin{array}{l}\text { Cement } \\
\text { East Binger } \\
\text { Glenn Pool } \\
\text { Garber } \\
\text { Purdy } \\
\text { Panther Creek } \\
\text { Stroud* } \\
\text { North Burbank } \\
\text { Hewitt } \\
\text { Hoco } \\
\text { Loc }^{+} \\
\text {Sho-Vel-Tum* } \\
\text { Velma } \\
\text { Stonebluft }\end{array}$ & $\begin{array}{l}\text { Polymer } \\
\mathrm{HC}-\text { mi scible } \\
\mathrm{CO}_{2} \\
\mathrm{CO}_{2} \\
\mathrm{CO}_{2} \\
\mathrm{Caustic} \\
\mathrm{Pol} \text { ymer } \\
\text { Micel lar-pol ymer } \\
\text { Polymer } \\
\text { Polymer } \\
\text { Steam-fracture } \\
\text { assist } \\
\text { Micel lar-polymer } \\
\text { Micel lar-polymer } \\
\mathrm{N}_{2}\end{array}$ & $\begin{array}{r}29 \\
1,510 \\
6,290 \\
2,530 \\
1,160 \\
700 \\
370 \\
3,850 \\
165 \\
1,570 \\
2,050 \\
60,400 \\
449 \\
240\end{array}$ & $\begin{array}{l}<5,000 \\
<5,000\end{array}$ \\
\hline Pennsy I vania & McKean & Brad ford ${ }^{+}$ & - Micel lar-polymer & 50,000 & $<5,000$ \\
\hline South Dakota & Harding & Buffalo $0^{+}$ & In situ & 110 & \\
\hline Texas & $\begin{array}{l}\text { Anderson \& Henderson } \\
\text { Anderson } \\
\text { Bordon \& Howard } \\
\text { Brazorla } \\
\text { Brazos } \\
\text { Crane } \\
\text { Crane \& Ector } \\
\text { Crane } \\
\text { Crane \& Upton } \\
\text { Culberson \& Reeves } \\
\text { Dawson }\end{array}$ & $\begin{array}{l}\text { Fairway } \\
\text { Slocum } \\
\text { East Vealmoor } \\
\text { Manvel } \\
\text { Kurten-Woodbine } \\
\text { Block } 31^{+} \\
\text {Jordan } \\
\text { Kite } \\
\text { North Cross } \\
\text { Geraldine Ford } \\
\text { South Wel ch }\end{array}$ & $\begin{array}{l}\mathrm{HC}-\mathrm{m} \text { iscible } \\
\text { In situ } \\
\mathrm{N}_{2} \\
\mathrm{Micel} \text { lar-polymer } \\
\mathrm{CO}_{2} \\
\mathrm{CO}_{2} \& \mathrm{~N}_{2} \\
\mathrm{CO}_{2} \& \mathrm{~N}_{2} \\
\mathrm{CO}_{2} \& \mathrm{~N}_{2} \\
\mathrm{CO}_{2} \& \mathrm{~N}_{2} \\
\mathrm{CO}_{2} \& \mathrm{~N}_{2} \\
\mathrm{CO}_{2} \& \mathrm{~N}_{2}\end{array}$ & $\begin{array}{r}1,580 \\
445 \\
856 \\
3,400 \\
1,120 \\
2,950 \\
931 \\
68 \\
596 \\
1,440 \\
664\end{array}$ & $\begin{array}{r}5,000 \\
<5,000\end{array}$ \\
\hline
\end{tabular}


Table 2.1 cont inued

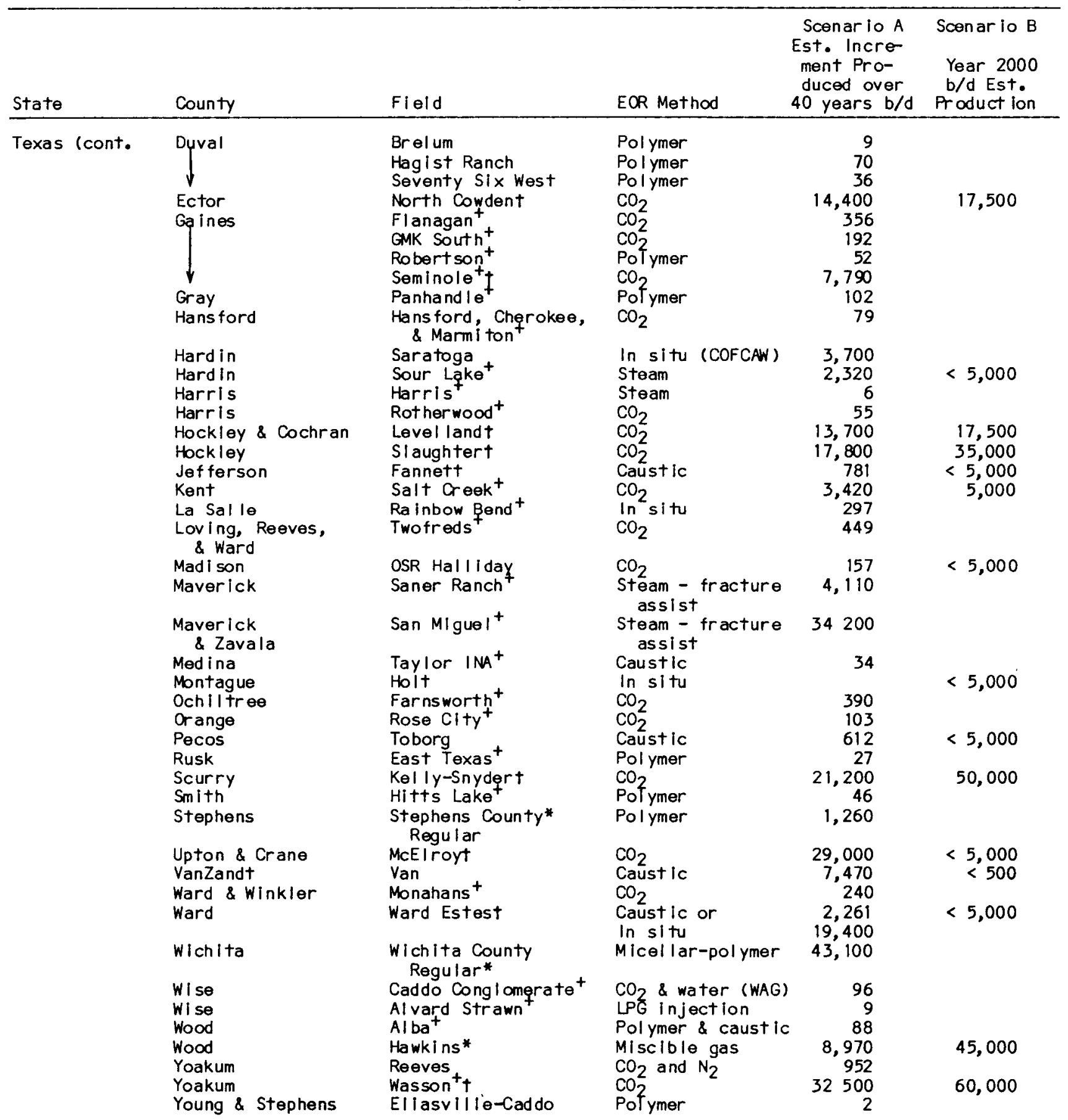




\begin{tabular}{|c|c|c|c|c|c|}
\hline \multicolumn{6}{|c|}{ Table 2.1 cont inued } \\
\hline State & County & Field & EOR Method & $\begin{array}{l}\text { Scenar io A } \\
\text { Est. Incre- } \\
\text { ment Pro- } \\
\text { duced over } \\
40 \text { years b/d }\end{array}$ & $\begin{array}{l}\text { Scenar io B } \\
\text { Year } 2000 \\
\text { b/d Est. } \\
\text { Product ion }\end{array}$ \\
\hline $\begin{array}{l}\text { Texas } \\
(\text { cont.) }\end{array}$ & $\begin{array}{l}\text { Zapata } \\
\text { Zavala \& Dimmit }\end{array}$ & $\begin{array}{l}\text { Charco Redondo } \\
\text { San Miguel-Elaine }\end{array}$ & $\begin{array}{l}\text { Caust ic } \\
\text { Polymer }\end{array}$ & $\begin{array}{l}11 \\
16\end{array}$ & \\
\hline Utah & $\begin{array}{l}\text { Garfield } \\
\text { San Juan } \\
\text { San Juan } \\
\text { Summit }\end{array}$ & $\begin{array}{l}\text { Upper Val ley } \\
\text { Aneth* } \\
\text { Lisbon } \\
\text { Bridger Lake* }\end{array}$ & $\begin{array}{l}\mathrm{Pol} \text { ymer } \\
\mathrm{CO}_{2} \\
\mathrm{CO}_{2} \\
\mathrm{HC}-\text { miscible }\end{array}$ & $\begin{array}{r}158 \\
5,220 \\
512 \\
909\end{array}$ & \\
\hline $\begin{array}{l}\text { West } \\
\text { Virginia }\end{array}$ & $\begin{array}{l}\text { Clay \& Roane } \\
\text { Kanawha } \\
\text { Lincoln } \\
\text { Roane }\end{array}$ & $\begin{array}{l}\text { Granny's Creek } \\
\text { Blue Creek+ } \\
\text { Griffithsvil let } \\
\text { Rock Creek (Walton) }\end{array}$ & $\begin{array}{l}\mathrm{CO}_{2} \\
\mathrm{CO}_{2} \\
\mathrm{CO}_{2} \\
\mathrm{CO}_{2}\end{array}$ & $\begin{array}{r}194 \\
86 \\
815 \\
1,750\end{array}$ & \\
\hline \multirow[t]{8}{*}{ Wyom ing } & $\begin{array}{l}\text { Big Horn } \\
\text { Big Horn }\end{array}$ & $\begin{array}{l}\text { Big Horn Bas in } \\
\text { Torchlight }\end{array}$ & $\begin{array}{l}\text { Steam } \\
\text { Micel lar-pol ymer }\end{array}$ & $\begin{array}{r}21,600 \\
557\end{array}$ & $<5,000$ \\
\hline & Campbel I & $\begin{array}{l}\text { Dillinger Ranch } \\
\text { Hartzog Draw } \\
\text { Kuehne, Hamm, \& } \\
\text { Simpson Ranches } \\
\text { Sharp } \\
\text { Stewart Ranch }^{+} \\
\text {Ute Muddy }\end{array}$ & $\begin{array}{l}\mathrm{CO}_{2} \\
\mathrm{CO}_{2} \\
\text { Pol ymer } \\
\text { Caustic } \\
\text { Pol ymer } \\
\text { Polymer }\end{array}$ & $\begin{array}{r}219 \\
1,300 \\
39 \\
21 \\
34 \\
42\end{array}$ & \\
\hline & $\begin{array}{l}\text { Converse } \\
\text { Crook } \\
\text { Crook } \\
\text { Fremont } \\
\text { Fremont }\end{array}$ & $\begin{array}{l}\text { Big Muddy* } \\
\text { Burnt Holl low+ } \\
\text { Kummerfield } \\
\text { Bison Basin } \\
\text { Winkelman Dome }\end{array}$ & $\begin{array}{l}\text { Micel lar-polymer } \\
\text { Caustic } \\
\text { Polymer } \\
\text { Caustic } \\
\text { Steam }\end{array}$ & $\begin{array}{r}6,500 \\
17 \\
27 \\
14 \\
3,080\end{array}$ & $\begin{array}{l}<5,000 \\
<5,000\end{array}$ \\
\hline & Johnson & $\begin{array}{l}\text { West Sussex \& } \\
\text { Dugout Creek+ } \\
\text { North Tisdale }\end{array}$ & $\mathrm{Oi}_{2}$ mining & $\begin{array}{r}285 \\
3,310\end{array}$ & \\
\hline & Natrona & $\begin{array}{l}\text { Salt Creek }{ }^{+} \\
\text {South Casper Creek } \\
\text { East Teapot }\end{array}$ & $\begin{array}{l}\text { Micellar polymer } \\
\text { Steam } \\
\text { Caustic }\end{array}$ & $\begin{array}{r}20,800 \\
1,330 \\
56\end{array}$ & $<5,000$ \\
\hline & $\begin{array}{l}\text { Park \& Hotsprings } \\
\text { Park }\end{array}$ & $\begin{array}{l}\text { Little Buffalo Basin }{ }^{+} \\
\text {Tensleep-Spring \& } \\
\text { Spring Creek }\end{array}$ & $\begin{array}{l}\text { Micel lar polymer } \\
\text { Steam }\end{array}$ & $\begin{array}{l}2,840 \\
2,330\end{array}$ & \\
\hline & Park & Willow Draw & Air injection & 35 & \\
\hline & Syblette & $\begin{array}{l}\text { Greater LaBarge } \\
\text { Long Is land } \\
\text { McDonald } \\
\text { Ruben } \\
\text { Sadd le Ridge } \\
\text { Tip Top Shal low }\end{array}$ & $\begin{array}{l}\text { Pol ymer } \\
\text { Pol ymer } \\
\text { Pol ymer } \\
\text { Pol ymer } \\
\text { Polymer } \\
\text { Pol ymer }\end{array}$ & $\begin{array}{r}146 \\
4 \\
53 \\
29 \\
39 \\
30 \\
\end{array}$ & \\
\hline \multicolumn{6}{|c|}{$\begin{array}{l}\text { *alculated from ref. } 8 \text { and } 9 . \\
{ }^{+} \text {Extracted from Enhanced Recovery Week. } \\
\text { FCurrent b/d in 011 \& Gas Journal 3/31/ }\end{array}$} \\
\hline
\end{tabular}


Table 2.2

Total Production by State

\begin{tabular}{|c|c|c|}
\hline & $\begin{array}{c}\mathrm{b} / \mathrm{d} \\
\text { Scenario A }\end{array}$ & $\begin{array}{l}\text { b/d Maximum } \\
\text { Scenario B }\end{array}$ \\
\hline $\begin{array}{l}\text { Alabama } \\
\quad \& \text { Florida }\end{array}$ & 7,680 & 5,000 \\
\hline Arkansas & 34,800 & 30,000 \\
\hline California & 955,000 & 620,000 \\
\hline Colorado & 44,600 & \\
\hline Illinois & 38,800 & 15,000 \\
\hline Indiana & 3,750 & \\
\hline Kansas & 2,740 & 10,000 \\
\hline Kentucky & 6,200 & \\
\hline Louisiana & 65,400 & 20,000 \\
\hline Mississippi & 12,700 & 5,000 \\
\hline Missouri & 60 & \\
\hline Montana & 1,570 & 5,000 \\
\hline Nebraska & 850 & 5,000 \\
\hline New Mexico & 7,080 & 10,000 \\
\hline North Dakota & 4,610 & \\
\hline Oklahoma & 80,600 & 15,000 \\
\hline Pennsy1vania & 50,000 & 5,000 \\
\hline South Dakota & 110 & \\
\hline Texas & 286,000 & 280,000 \\
\hline Utah & 6,800 & \\
\hline West Virginia & 2,850 & \\
\hline Wyoming & 64,700 & 20,000 \\
\hline Tota1 b/d & 1677,000 & $1,045,000$ \\
\hline
\end{tabular}

Some fields for which data were inadequate had to be dropped from the data base, and newer EOR projects, namely, projects in fields described in 1980 in the Oil and Gas Journal (OGJ) and Enhanced Recovery Week (ERW), were then added. However, because a few giant fields* that are also prime candidates for EOR slipped through the screening of the first two references mentioned above, additions from OGJ and ERW 1980-1981 data were few, at least insofar as national production figures are concerned. However, some of the more recent projects were important for the assessment of potential local environmental impacts and problems (Chapter 5 of this report).

Production estimates for the fields in Scenario A were based on two assumptions. The first was that an approximate estimate of a tertiary increment (i.e., recoverable tertiary oil) was possible for every field within the data base; the second was that each field and those reservoirs which were currently candidates for EOR might produce their entire increment during the

*A giant field is one with at least $10^{9}$ barrels of oil in place at the time of discovery. 
next 40 years. Some small fields and a few large ones could conceivably go into fieldwide production, producing four to ten times the 40-year average in peak years and then dropping out, exhausted, after a decade or two. However, most large fields (which form the major part of the production base) appear destined for section-by-section development. Thus, time averaging is a rational approach for a production scenario. Again, a production scenario like A, based on smoothing out development of fields in time, is relatively insensitive to the fluctuations from smaller fields. However, an environmental scenario should not skip blithely over effects from projects where EOR rapidly does go fieldwide. This problem is discussed in Chapter 5.

In most cases, the Estimated Tertiary Increments (or ETI's) from which the time averaged production of Scenario $A$ is derived are obtained from three quantities: a) tertiary target or remaining oil in place (ROIP), b) residual oil saturation before enhanced recovery $\left(S_{O R}\right)_{i}$, and $\left.c\right)$ residual oil saturation after enhanced recovery $\left(\mathrm{S}_{\mathrm{OR}}\right)_{\mathrm{f}}$. For each reservoir undergoing steam, miscible gas, or micellar-polymer flood:

$$
\operatorname{ETI}=\operatorname{ROIP}\left[1-\left(\mathrm{S}_{\mathrm{OR}}\right)_{\mathrm{f}} /\left(\mathrm{S}_{\mathrm{OR}}\right)_{\mathrm{i}}\right]=\operatorname{ROIP} \times \mathrm{F}\left(\mathrm{S}_{\mathrm{OR}}\right) \text {. }
$$

For fields subjected to improved waterflood or caustic flooding, ETI's are assumed to be 0.1 times cumulative production from primary and secondary techniques, as suggested by ref. 8. Time-averaged production for each field over 40 years (in $\mathrm{b} / \mathrm{d}$ ) is simply obtained by dividing the ETI's by the product, $365 \times 40$.

ETI's for the large fields and reservoirs in Scenario A are derived from data contained in refs. 8 and 9 . Theoretically, $\left(\mathrm{S}_{\mathrm{OR}}\right)_{\mathrm{f}}$ is a function of $\left(\mathrm{S}_{\mathrm{OR}}\right)_{\mathrm{i}}$ and it depends upon EOR technique. [I.e., $\left(\mathrm{S}_{\mathrm{OR}}\right)_{\mathrm{f}}$ depends upon API degrees for steamflood and the effectiveness of primary and/or secondary production for miscible gas.] For example, using steam on a field with $13^{\circ}$ API oil in place, an approximate formula ${ }^{8}$ gives:

$$
\left(\mathrm{S}_{\mathrm{OR}}\right)_{\mathrm{f}}=(0.35 \times 0.08)+(0.35 \times 0.30)+\left[0.30 \times\left(\mathrm{S}_{\mathrm{OR}}\right)_{i}\right]
$$

where 0.35 is taken to be the sweep efficiency in both the steam-swept and hot water-swept zones, and where the fractional unswept volume is 0.30 . The residual oil saturations in the steam-swept and hot water-swept zones after flooding are assumed to be 0.08 and 0.30 , respectively. Arithmetic for steam flood shows that the factor $F\left(S_{O R}\right)=\left[1-\left(S_{O R}\right)_{f} /\left(S_{O R}\right)_{i}\right]$ has values of 0.434 and 0.560 when $\left(\mathrm{S}_{\mathrm{OR}}\right)_{1}=0.500$ and 0.950 , respectively. Similar calculations were performed to obtain $F$ for fields undergoing chemical and miscible gas floods.

ETI's for many other fields and reservoirs relied upon past production data10-16 as follows. The Energy Information Agency (EIA) data base ${ }^{9}$ includes remaining oil in place, ultimate primary and secondary production for each field, and cumulative production through 1976. For three "regions" of the United States (California, Texas, and all other areas), the ratios of total remaining oil in place to cumulative production for EIA big fields were calculated. These ratios - 3.90 for California, 2.31 for Texas, and 1.46 for all other areas - are then used to estimate remaining ofl in place in small 
fields, given cumulative production figures. $O G J^{7}$ data provided the $\left(S_{O R}\right)_{i}$ 's needed to calculate the factors $F\left(S_{O R}\right)$ in some cases. Again, the product of F's and ROIP's gives ETI's for such small fields.

For many of the fields described in Enhanced Recovery Week and by the U.S. Department of Energy, 17 however, ROIP's or ETI's (or both) are given by industry sources and these data are used straightforwardly in Scenario $A$. Fields which fall into this category are specially denoted in the tables. In cases in which only the ROIP or tertiary target appeared in ERW, recent1y published 18 conservative $F$ factors (i.e., 0.35 as the average for steam, 0.33 for in situ, 0.17 for $\mathrm{CO}_{2}, 0.365$ for micellar-polymer, and 0.04 for polymer) are used to produce the ETI's from which production figures are calculated. A small number of fields currently undergoing EOR and mentioned in ref. 6 and 7 had to be excluded from Scenario A because neither production figures nor Estimated Tertiary Increments were available.

Scenario B was devised as an "oilman's best estimate" of EOR from major U.S. oil fields in the year 2000. Production estimates reflect actual current production rates, the state of development of the fields involved, and engineering judgment about the success of various EOR methods in different regions. It should not be surprising that overall production figures seem lower for Scenario B than for Scenario A, because A includes [theoretically] high production from many fields with vast potential but few encouraging results to date. As an example, the Bradford field in McKean County, Pennsylvania, may have $2000 \mathrm{Mb}$ ROIP, 19 but the secret for obtaining optimum production from that target, i.e., $50,000 \mathrm{~b} / \mathrm{d}$ averaged over 40 years, is still locked up in its relatively impermeable $(7$ millidarcy) sands. Thus, Scenario B's production estimate of $<5000 \mathrm{~b} / \mathrm{d}$ may be better than Scenario A's. As a further note, opinions on Scenario B were solicited at a 1980 workshop on EOR, 20 where the estimates were accepted as reasonable at that time.

Some observations about Tables 2.1 and 2.2 and the Scenarios A and B are in order:

1. Giant reservoirs are the dominant producers in both scenarios.

2. Recoverable tertiary oil (as the estimated tertiary increment) for each reservoir in each field can be estimated only within a factor of 2 because of uncertainties in two factors: tertiary target or remaining oil in place as determined by the residual oil saturation, and residual ofl saturation after enhanced recovery.

3. Enhanced recovery techniques in this report include steam drive and steam soak; in situ combustion, miscible gas injection (including $\mathrm{N}_{2}$ and hydrocarbons as well as $\mathrm{CO}_{2}$ ); micellar polymer flooding; polymer and/or caustic flooding. In other words, we use the term "tertiary recovery" in the same traditional way as does industry (e.g., see ref. 7).

4. The tertiary increment for each field and reservoir is defined to be that ofl over and above a declining production curve that 


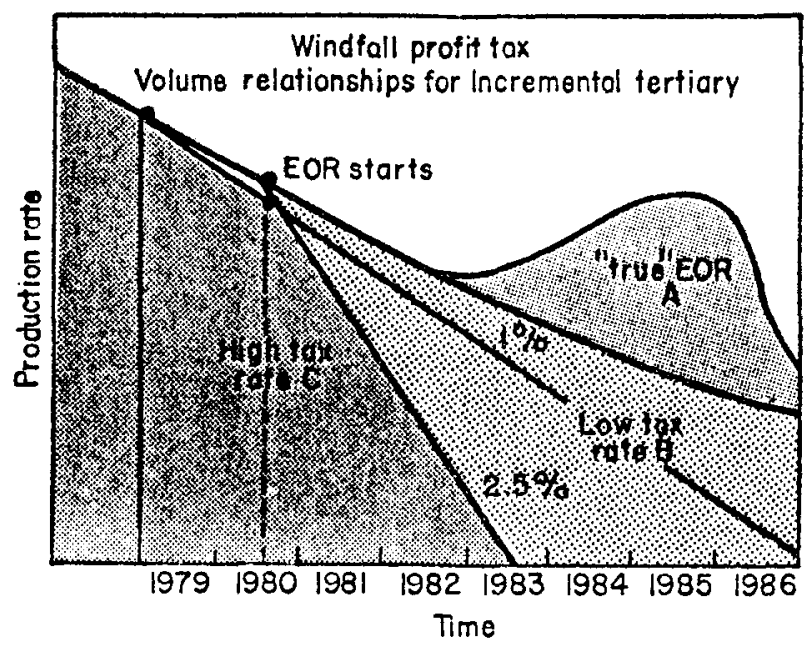

Figure 2.3. Windfa11 Profits Tax and EOR. True EOR is represented only by the area $A$, although existing regulations define EOR to be $A+B$. (Reference 20.)

would be assumed or projected if a typical waterflood or secondary recovery were extended to its economic limit. The distinction between true tertiary oil and tertiary oil as defined by existing regulations is shown in Figure 2.3.

5. The number of barrels of oil per day for steam fields is the gross production, including approximately one barrel of oil in three burned to generate steam. Thus, the net oil production is only about two-thirds of the gross production. If in the future a way is found to produce steam without burning crude oil, e.g., using coal, 21 net production would then be the same as production.

6. Because of the procedures and assumptions used in this chapter, the oil production estimates of Scenarios A and B may be regarded generally as "high" and "low" estimates, respectively, for tertiary production by the turn of the century. Where the EOR data base is fairly complete, as it is for Texas, the production figures appear to converge quite well. On the other hand, the large potential of some California, Wyoming, and oklahoma fields contrasts with their relatively slow development, and explains the factor of 2 or 3 by which the production scenarios differ.

7. It should be emphasized that the scenarios are designed only as an exercise to produce input for assessments. of environmental impacts and problems (Chapter 5). A truly predictive production model would require better input data and more detailed economic analysis than is called for in this report. 
8. In fields where several EOR methods were being tried, only the most common method in that region was assumed in production for Table 2.2.

\subsection{ONSHORE EOR VS OFFSHORE EOR}

This report was intended from the outset to treat only onshore or mainland EOR in the lower 48 states. However, it is obvious that certain reservoirs in California (e.g., in the Huntington Beach field) lie offshore as well as onshore, and that other reservoirs in Louisiana (e.g., Grand Isle and South Pass), considered to be ripe for EOR, lie in the Gulf of Mexico. Those fields were included in our scenario because they are either producing currently or are the subjects of pilot studies and future plans for enhanced recovery.

Although it would be tempting to extrapolate further and include such areas as the Texas and Louisiana offshore fields 22 and all reservoirs off the California cost, such fields have been excluded because the class of environmental risks is sufficiently different for offshore production (i.e., platform space availability, well spacing, etc.) that they should be the subject of another report. Moreover, the question of enhanced recovery from the resources off the outer continental shelves (OCS) is largely speculation pending better estimation of oil in place. Nevertheless, it should be mentioned that some participants at the 1980 Workshop on EOR2O estimated that OCS enhanced recovery could make a considerable contribution to our nation's oil supply after most onshore targets have been exploited.

The matter of proper timing becomes crucial for offshore EOR operations because decisions must be made early in the primary production phase of fields. Unlike land-based operations in which previously abandoned wells can be recompleted without too much difficulty, offshore wells must be maintained through the tertiary stage without abandonment. Once platforms are in place, they remain there throughout the entire development, including primary, secondary, and tertiary stages. Consequently, industry sources feel that environmental assessments for offshore EOR should be undertaken as soon as possible in the production cycle.

\subsection{ALASKAN EOR}

Like offshore EOR, tertiary recovery in the fragile Alaskan environment may also present special problems beyond the scope of this report. Even though the physical changes incurred in bringing an oil field into tertiary phase of production are incremental (i.e., these caused by construction, drilling, road building, etc.), and even though they may appear infinitesimal for most projects in the lower 48 states, their impacts on the Alaskan tundra are much greater than in other places. Alaska will probably be the scene of substantial enhanced recovery by the year 2000. For example, much of the production from the Prudhoe Bay field, currently running over one million $\mathrm{b} / \mathrm{d}$, might come from $\mathrm{CO}_{2}$ floods by the end of the century, and thus Alaskan fields could contribute a large fraction of total US EOR at that time. 
Therefore, at some point soon, an Alaskan EOR production scenario and its related environmental risk assessment should be considered in detail.

\section{REFERENCES}

1. The Potentials and Economics of Enhanced 0il Recovery, Federal Energy Administration Report, Lewin and Assoc., Inc., B-76/221, April 1976.

2. J. Heinkel, Projections of Enhanced Oil Recovery, 1985-1995, DOE-Energy Information Administration, Oil and Gas Analysis Div., Office of Energy Source Analysis, TR/ES 79-30, September 1979.

3. Enhanced Oil Recovery Potential in the United States. Office of Technology Assessment, January 1978.

4. Enhanced Oil Recovery; National Petroleum Council, December 1976.

5. T.M. Doscher, Enhanced recovery of crude oil, Am. Sci., 69, No. 2, 193-9 (1981).

6. International Petroleum Encyclopedia, the Petroleum Publishing Co., pp. 257-273, Tulsa, 1979 .

7. S.L. Matheny, Jr., EOR methods help ultimate recovery; 0il Gas J., pp. 79-124, March 31, 1980.

8. Enhanced Oil Recovery Model. Technical Memorandum TM/ES/79. Energy Information Administration, DOE.

9. Big Fields File for Enhanced Oil Recovery. Candidate Reservoirs, Energy Information Agency, DOE.

10. Internationa1 0il and Gas Development. Yearbook 1977. Int. Oil Scouts Assoc. Part II, Vol. XLVII, 1977.

11. The Railroad Commission of Texas, Oil and Gas Div., Annual Report 1979.

12. J. VandenBerg, Petroleum Industry in Illinois, 1978, Illinois State Geological Survey, Illinois Petroleum 16, 1980.

13. D.H. Cardwel1, 011 and Gas Fields of West Virginia, West Virginia Geological and Economic Survey, Mineral Resources Ser. No. 7, 1977.

14. Wyoming Oil and Gas Statistics 1978. Wyoming 011 and Gas Conservation Commission, Casper.

15. Summary of Field Statistics and Drilling Operations Louisiana 1978, Office of Conservation, Geological 0il and Gas Division, Louisiana Dept. of Nat1. Resources, Baton Rouge. 
16. 65th Annual Report of the State Oil and Gas Supervisor, Publ. No. PR 6. California Div. of Oil and Gas, Sacramento, 1980.

17. J. Goodrich, and R. Watts, Target Reservoirs for $\mathrm{CO}_{2}$ Miscible Flooding Final Report. Report by Gruy Federal Inc. for DOE, DOE/MC/08341-17.

18. Consultant gives gloomy EOR forecast, Enhanced Recovery Week, p. 5, May 11,1981 .

19. Pennzoil has headaches and high hopes at Bradford, Ibid, p. 3 .

20. E. Kaplan, M.H. Garre11, E.F. Riede11, and J. Sathaye, Proceedings of Department of Energy/Office of the Environment Workshop on Enhanced 0il Recovery: Problems, Scenarios, Risks, BNL 51406, abbreviated version in Oil Gas J., pp. 157-64, October 5, 1981.

21. Researcher says coal to make cheaper steam, Enhanced Recovery Week, p. 5, May 18, 1981 .

22. Gulf of Mexico liquids, gas reserves rise, 0il Gas J., p. 65, February 16,1981 . 
This chapter describes currently used tertiary recovery techniques. Brief descriptions of thermal EOR, chemical flooding, and miscible gas flooding are given.

\subsection{TECHNIQUES}

Enhanced oil recovery methods are broadly categorized as: (1) chemical flooding; (2) miscible gas displacement; and (3) thermal. Each technique has unique advantages and disadvantages. Its application may require specific reservoir conditions, such as certain rock, fluid, temperature, and pressure characteristics. All of these methods differ in complexity and the amount of experience that has been derived from field applications varies widely.

Chemical recovery processes include micellar-polymer, polymer, and alkaline flooding. In micellar or surfactant flooding, detergent like materials are injected to modify the chemical interaction of oil with its surroundings, and partially dissolve the oil. Much of the remaining oil is produced along with fluids from the reservoir. In polymer flooding, chemicals such as polyacrylamides or polysaccharides are added to the injected water to improve the total amount of pore volume swept (i.e., sweep efficiency) during oil displacement by improving the mobility ratio and increasing the swept pore volume. Alkaline solutions react with the acid components of crude oil to form detergent like materials which reduce the ability of the formation to retain oil and thereby improve recovery efficiency.

In miscible gas recovery techniques, the injected gas dissolves in the contacted oil, forming a single-phase* fluid that flows through the reservoir more easily than the original crude oil. In various immiscible gas recovery techniques, the injected gas only partially dissolves in the contacted oil and a single phase does not form. A variety of injection fluids may be used to achieve miscibility, including carbon dioxide, petroleum hydrocarbons such as propane, and nitrogen. In the future, hydrocarbon miscible techniques will probably not be used because of the rising expense and general unavailability of propane and ethane. The use of carbon dioxide miscible floods is constrained by operational problems, as we11 as by the scarcity of $\mathrm{CO}_{2}$ supplies in close proximity to potential project sites. Nitrogen is being tried in a number of areas and may prove useful. In addition to miscible single-phase displacement, both nitrogen and carbon dioxide are used immiscibly with good results.

Thermal recovery methods are designed to reduce the viscosity of oils and thus to increase the flow within the reservoir and toward the production wells. Steam soak and steam injection processes utilize steam as the injected fluid and the heat source. In situ combustion injects air and water, burning part of the crude ofl in the reservoir to generate heat. Thermal methods are usually considered best suited to the recovery of viscous crude oils, although they are not limited exclusively to use with heavier

*There may also be a second aqueous phase present. 
crudes. These techniques are not applicable to all reservoirs, however, because of the required formation porosity for a successful project.

Steamflooding and miscible carbon dioxide flooding are the two most promising tertiary techniques currently used. The choice of which tertiary recovery process to use for a particular oil reservoir is determined by the viscosity of the crude oil; reservoir properties such as porosity and rock type; the avallability of injection materials; economic considerations; and potential environmental impacts. Local environmental regulation and costs of injection materials also influence the choice of recovery process.

Therma1 recovery applications are responsible for an estimated $30 \%$ (1980) of the total oil produced in the state of California, 1 the major thermal oil-producing state. Steam methods currently produce $295,700 \mathrm{~b} / \mathrm{d}^{4}$ ( $77 \%$ of all EOR), while all thermal methods combined produce $307,900 \mathrm{~b} / \mathrm{d}$ ( $80 \%$ of all EOR). For comparison, chemical methods account for $2400 \mathrm{~b} / \mathrm{d}(0.6 \%)$; $\mathrm{CO}_{2}$ miscible methods account for $21,500 \mathrm{~b} / \mathrm{d}(6 \%)$ with other gas methods accounting for the remainder.1

\section{2 CHEMICAL RECOVERY METHODS}

Chemical flooding is the most complex and sophisticated of the three broad categories of EOR methods. It is also the least understood with the highest degree of uncertainty in field performance. However, if used with proper design and control, it could provide the greatest opportunity for maximum oil recovery. The three methods of chemical recovery (alkaline, polymer, and micellar-polymer) produce oil by different mechanisms.

\subsubsection{Alkaline Flooding}

Alkaline, or caustic flooding with sodium hydroxide ( $\mathrm{NaOH}$ ), sodium carbonate $\left(\mathrm{Na}_{2} \mathrm{CO}_{3}\right)$, or sodium silicate $\left(\mathrm{Na}_{2} \mathrm{SiO}_{3}\right)$ improves oil recovery by reducing interfacial tension, by spontaneous emulsification, and by wettability reversal (that is, changing the reservoir rock from oil-wet to waterwet). Each of these mechanisms requires somewhat different initial conditions with respect to reservoir ofl, rock, and injection water properties. Not all of these mechanisms may be important in any single caustic flood operation.

These recovery mechanisms are governed by the in situ formation of surfactants from the neutralization of petroleum acids by the alkaline chemicals. The acid content is normally higher in lower API gravity crude ofls. Hence, this process works best for moderately viscous, naphthenic crudes with low API gravity.

Emulsification also provides some mobility control, although other chemicals (polymers) may be required as well for good mobility control.

\subsubsection{Polymer Flooding}

Polymer flooding differs from all the other tertiary methods in that the incremental oil comes only from improved sweep efficiency. In an ideal 
homogeneous reservoir, polymer flooding would not recover any more oil than a waterflood. However, all real reservoirs are inhomogeneous and thus polymer flooding can achieve additional oil recovery over that recovered from use of a waterflood.

Polymer flooding improves sweep efficiencies by reducing the mobility contrast between the in-place and injected fluid. A fluid's mobility is defined by the ratio of the permeability of formation to the fluid's viscosity. The mobility ratio is the mobility of the injected fluid divided by the mobility of the crude oil; a favorable ratio is 1 or less. Polymers are chemicals which increase the viscosity of water and can also decrease the effective permeability of reservoir rock to water. More of the reservoir area is thus swept by the fluid, and oil recovery is increased.

Reservoirs do not have uniform permeabilities and porosities, and fluid that is injected into a vertical interval will seldom travel through that zone with a uniform flood front. The fluid will preferentially traverse those areas of higher permeability, leaving oil behind in the less permeable areas. As shown in Figure 3.1, polymer injection can redistribute the flow of injected fluids relative to waterflooding by reducing the permeability in more conductive sections and achieving a more uniform distribution profile for maximum oil recovery.

A polymer is a large chain molecule formed by thousands of repeating blocks called monomers. Polysaccharide biopolymers and partially hydrolyzed polyacrylamides are the two polymers most commonly used in polymer flooding operations. Polysaccharides are grown by microorganisms, whereas polyacrylamides are synthetically produced by the combination of carbon, hydrogen, and oxygen into basic monomer units. Both types of polymers are provided in dry powdered forms or as concentrated water/oil emulsions.

\subsubsection{Micellar-Polymer Flooding}

Micellar-polymer flooding is a multiple-slug or multiple-stage process. Typically, four or more different chemical slugs are used. These are the preflush, the micellar solution, the polymer, and the drive water (see Figure $3.2)$.

The first slug injected is the preflush. Its function is to adjust the reservoir's salinity to provide maximum compatibility between the micellar solution and the reservoir fluids. The salinity balance also serves as a chemical tracer which can be used to obtain information about reservoir flow characteristics. The difficulty of matching salinities is a major constraint to the application of micellar-polymer flooding in many reservoirs.

The micellar or surfactant solution is the second of the chemical slugs injected. The surfactant lowers the interfacial tension between the injected fluid and the reservoir oil and water to almost zero. Capillary forces are minimized, improving the displacement efficiency.

To ensure good sweep efficiency, the micellar slug is followed by a polymer solution. The polymer slug may be either polysaccharide or polyacrylamide and functions in the same manner as in a polymer-augmented waterflood. The polymer solution develops a favorable mobility displacement and 

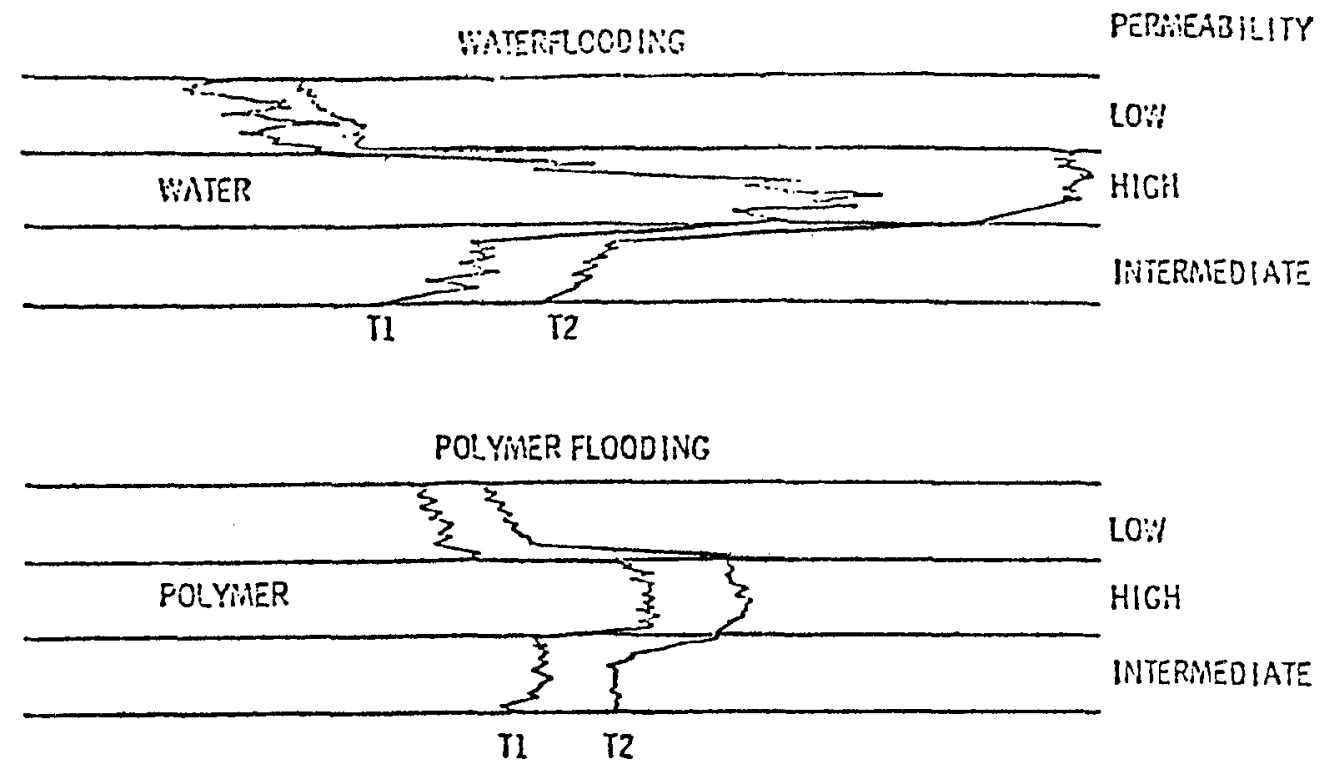

Figure 3.1 Improvement of vertical sweep efficiency by polymer flooding. $\mathrm{T} 1$ and $\mathrm{T} 2$ are time intervals following initiation of flood.

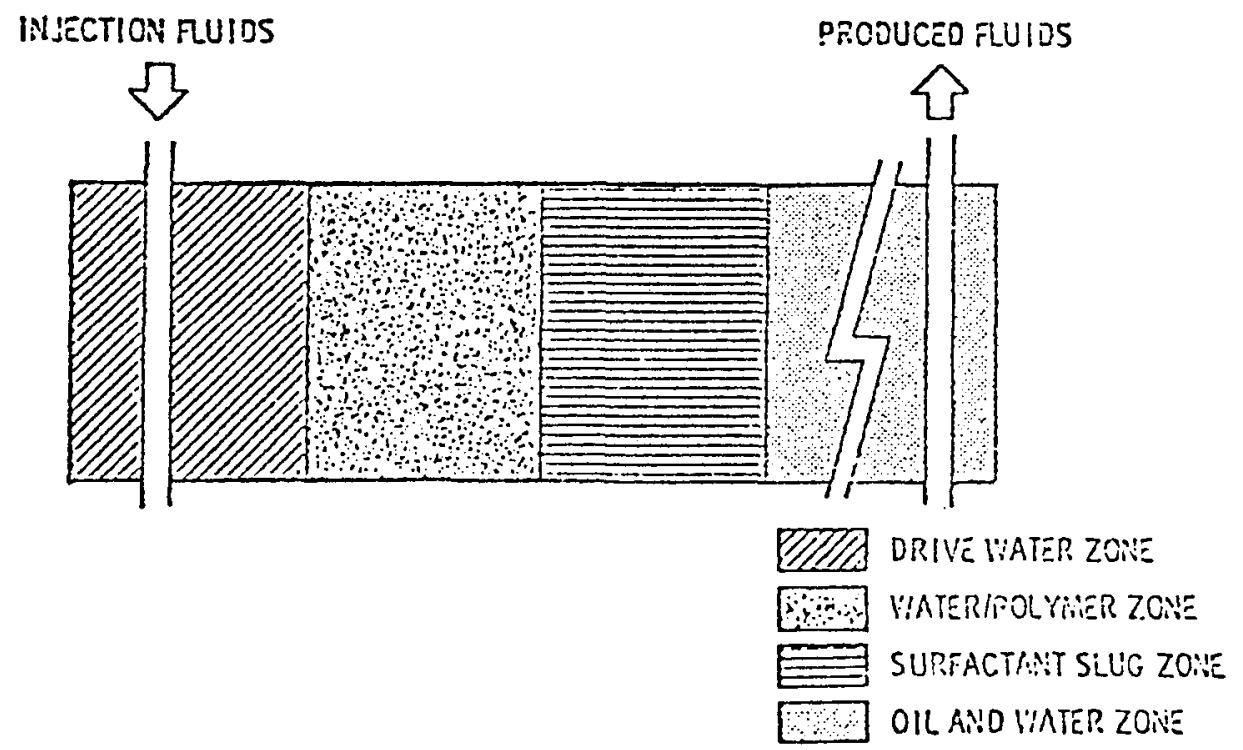

Figure 3.2. Surfactant flooding process. 
improves sweep efficiency. In addition, it preserves the integrity of the costly slug of surfactant chemicals, and prevents invasion of the slug by the drive water.

The final fluid of the series is drive water, which is usually identical to the water used for a waterflooding operation.

Crude oil and water are displaced ahead of the micellar slug, forming a stabilized oil and water bank. The movement of the slug through the reservoir is stabilized by the mobility buffer. Drive water pushes the mobility buffer through the desired reservoir zone to producing wells.

The efficiency of micellar-polymer flooding is dependent upon a number of complex factors. Among the most important variables are the amount of oil which will actually be contacted by the surfactant and how uniformly the mobility buffer pushes the preceding fluids through the reservoir. Other factors affecting process efficiency include the extent of surfactant adsorption and retention in reservoir rock (loss of surfactant chemical), deterioration of the micellar slug as a result of aging or excessive formation salinity (loss of surfactant activity), and nonhomogeneity of the reservoir rock (poor sweep efficiency).

The combined use of a micellar fluid followed by polymer buffer seems to be an ideal displacement process. It provides the high oil displacement of a miscible flood, combined with an optimal and highly efficient areal sweep. Laboratory core tests frequently recover $100 \%$ of the oil in place. A number of technically successful pilot tests have been performed. Surfactant flooding takes place on a limited commercial basis.

\subsection{MISCIBLE AND IMMISCIBLE GAS RECOVERY}

Improved recovery of crude oil by miscible displacement was first researched and tested in the early 1950s. The method generally involves the injection of a gaseous material whose composition acts as a solvent for the crude oil. The interfacial and capillary forces between the gas and the oil are eliminated by miscibility, thereby increasing the flow of oil through the reservoir. Four gases which are commonly used in the techniques are liquefied petroleum gas, carbon dioxide, nitrogen, and flue gases. Not all of these gases yield a true miscible displacement. The miscible flooding techniques may be divided into those which employ hydrocarbon gases as injection materials and those which use other gases.

In an actual gas flood, both miscible and immiscible displacement probably occur in different portions of the reservoir and at different times during the flood. The distinction between these mechanisms is possible only in carefully controlled laboratory tests. Therefore, the two mechanisms will not be discussed separately, and the partially miscible (immiscible) flood will be considered to be part of the miscible displacement mechanism in this document.

Liquefied petroleum gas (LPG) flooding was one of the first miscible techniques. Beginning in 1956, LPG was used to increase both oil recovery 
and production rates. LPG at that time was cheap and was viewed as a useful, economical injection material. However, it was found that variations in reservoir structure and poor mobility ratios of the injected fluids resulted in poor economics; the ratio of produced oil to injected gas was too low to achieve economic success. Because of its increased cost, LPG is not currently considered as a feasible injection gas.

Flue gases are highly variable mixtures and may contain nitrogen, argon, carbon oxides, sulfur oxides, hydrogen, oxygen, nitrogen oxides, water, and uncombusted gases. These gases are relatively cheap and easy to obtain, and they have been used successfully in field tests (e.g., Hawkins field in Texas and East Binger field in Oklahoma).

Both carbon dioxide $\left(\mathrm{CO}_{2}\right)$ and nitrogen $\left(\mathrm{N}_{2}\right)$ are miscible with some crude oils under proper conditions. Both gases are also used for immiscible displacement as well as miscible displacement. The recovery process is shown schematically in Figure 3.3. The discussion here will focus on the use of $\mathrm{CO}_{2}$ as an injected gas since more is known about its behavior, although nitrogen has been successfully used in field tests (e.g., Fordoche in Louisiana).

The injection of carbon dioxide in an oil reservoir can increase oil recovery and production rates by a variety of mechanisms. $\mathrm{CO}_{2}$ is highly soluble in some crude oils, and also causes these oils to swell. The added volume and energy of the expanded oil helps push it through the reservoir. As the oil becomes saturated with $\mathrm{CO}_{2}$, its viscosity is also reduced, improving its flow to producing wells. A larger percentage viscosity reduction occurs with the more viscous crudes. Carbon dioxide is also highly soluble in water and expands the reservoir brine (from perhaps 2 to $7 \%$ ) when it goes into solution, adding even more energy to the reservoir. The densities of oil and water are similar when saturated by $\mathrm{CO}_{2}$, minimizing gravitational segregation of the fluids.

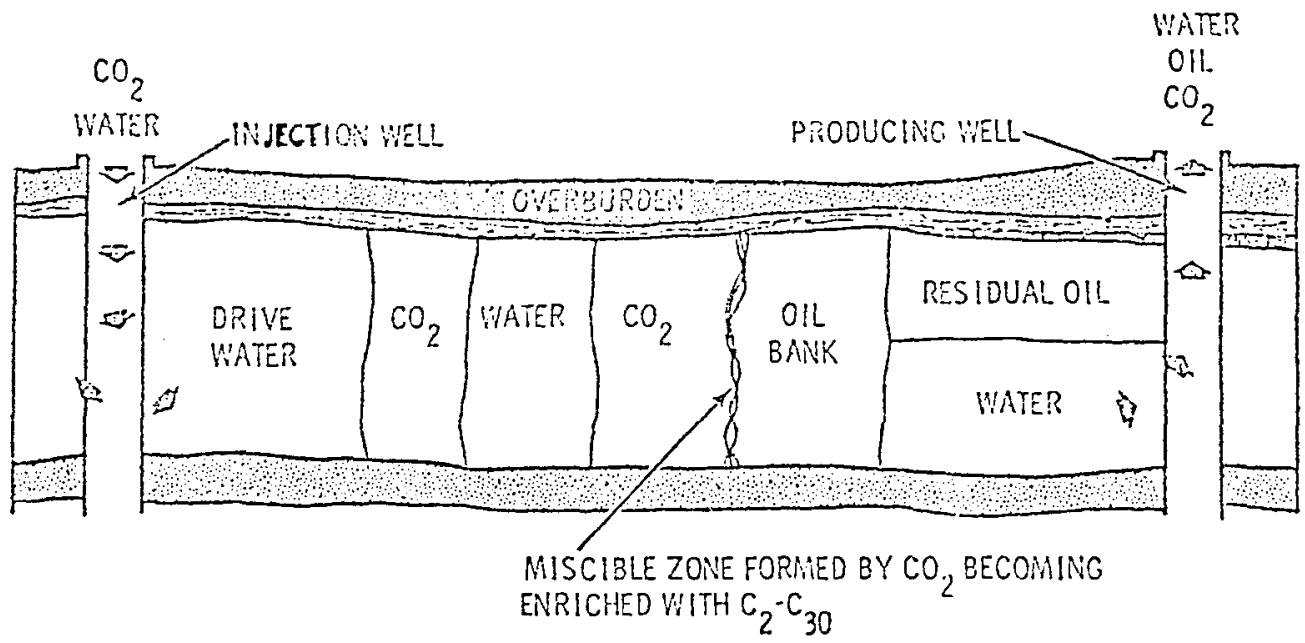

Figure 3.3 Schematic of the $\mathrm{CO}_{2}$ miscible process. 
In $\mathrm{CO}_{2}$ miscible flooding, the reservoir pressure must be maintained above the miscibility pressure. Impurities in the $\mathrm{CO}_{2}$ stream such as nitrogen and methane increase the pressure required to achieve miscibility. In the field both miscible and immiscible displacements may occur simultaneously in different portions of the reservoir.

The volume of carbon dioxide injected ranges from 25 to $50 \%$ of swept pore volume. The $\mathrm{CO}_{2}$ slug may be driven by water or inert gases. More of the reservoir pore volume is swept when using alternate water and $\mathrm{CO}_{2}$ cycles. Premature breakthrough of carbon dioxide is a normal occurrence. Thus, separation and reinjection facilities for $\mathrm{CO}_{2}$ must be included in plant design of the gas flood.

\subsection{THERMAL RECOVERY}

Thermal recovery has been used extensively since the early 1950s and is a major method of production. ${ }^{2}$ Thermal recovery processes may be divided into two main categories: steamflooding, using either cyclical injection or drive methods, and in situ combustion. Thermal recovery methods rely upon heat to reduce the viscosity of crude oil and facilitate its flow to producing wells. Heat can be supplied from an external source by injecting hot water or steam into a reservoir, or it can be generated directly within the reservoir by burning some of the in-place crude oil (in situ combustion).

Steam injection recovery methods generate heat at the surface in the form of steam and inject this heat into the reservoirs via well casings. Part of the recovered crude oil is normally used to generate steam. Cost considerations make the use of a cheaper fuel, such as coal, desirable, but this option may be precluded by environmental constraints. (See Chapter 5.) The ratio of steam to water injected may vary from mostly steam (high quality) to mostly water (low quality). The quality of the steam is the weight fraction of water converted to steam, and is typically maintained at $80 \% .3$

There are a variety of mechanisms in operation during reservoir steaming which improve the displacement efficiencies of oil recovery. Besides the reduction of oil viscosity, which facilitates the flow of oil to producing wells, crude oil expansion and steam distillation also help increase oil recovery. 3

\subsubsection{Cyclic Steam In jection}

Cyclic steam injection, also variously known as steam soak, huff and puff, or steam stimulation, involves a period of steam injection, followed by a waiting period. The well is then placed on production (see Figure 3.4). This method is particularly important in California where it is used in a number of steeply dipping reservoirs. The main method of recovery here is gravity drainage.

The use of steam as an injection fluid has two important advantages. First, it reduces the crude oil viscosity so that it will flow more easily; and second, it causes the oil to swe11, resulting in additional energy to push the oil through the reservoir. Furthermore, it has an effect on the 


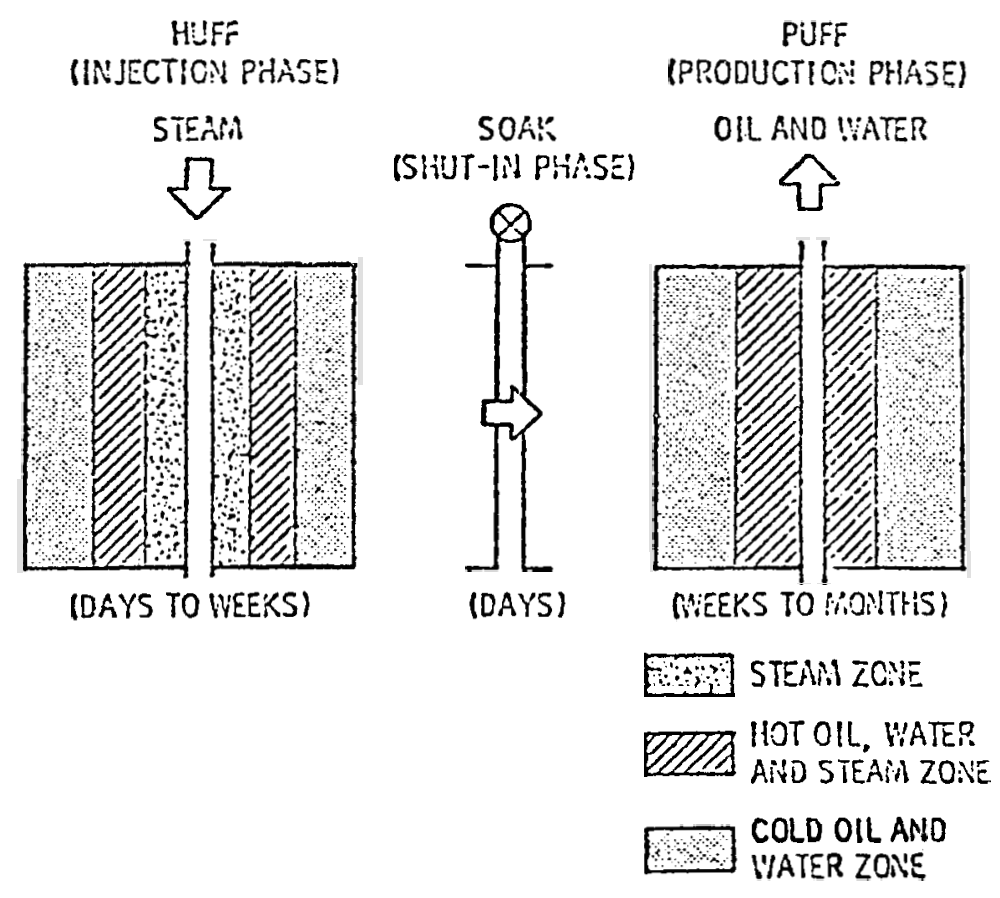

Figure 3.4. Cyclic steam stimulation process.

overall wettability of the reservoir, causing oil-wet reservoirs to be changed into water-wet, at least where the steamflood has been operational.

Cyclic steam injection, like most methods, generally becomes less efficient as the number of cycles increases. Thus, cyclic steam injection is frequently used as a precursor to steamflooding. It is quite common for a heavy oil reservoir to have very low net permeability. Although the absolute permeability may be very high, the resistance to internal flow is frequently very low because of the viscous crude oil present, and the reservoir is stimulated cyclicly with steam in order to remove some of the oil. This provides better communication between adjacent injector-producer pairs, and allows conversion from cyclic steam injection to steam drive.

\subsubsection{Steam Drive}

Steam drive, steam displacement, or steamflooding entails continuous injection of steam into a reservoir to displace oil into a nearby producer we11. Conceptually, this is exactly the procedure that is used in the waterflooding process except that steam is used instead of water. This process is shown schematically in Figure 3.5. Steam drives normally yield a higher recovery of oil in place in a shorter time than cyclic steam injection, 


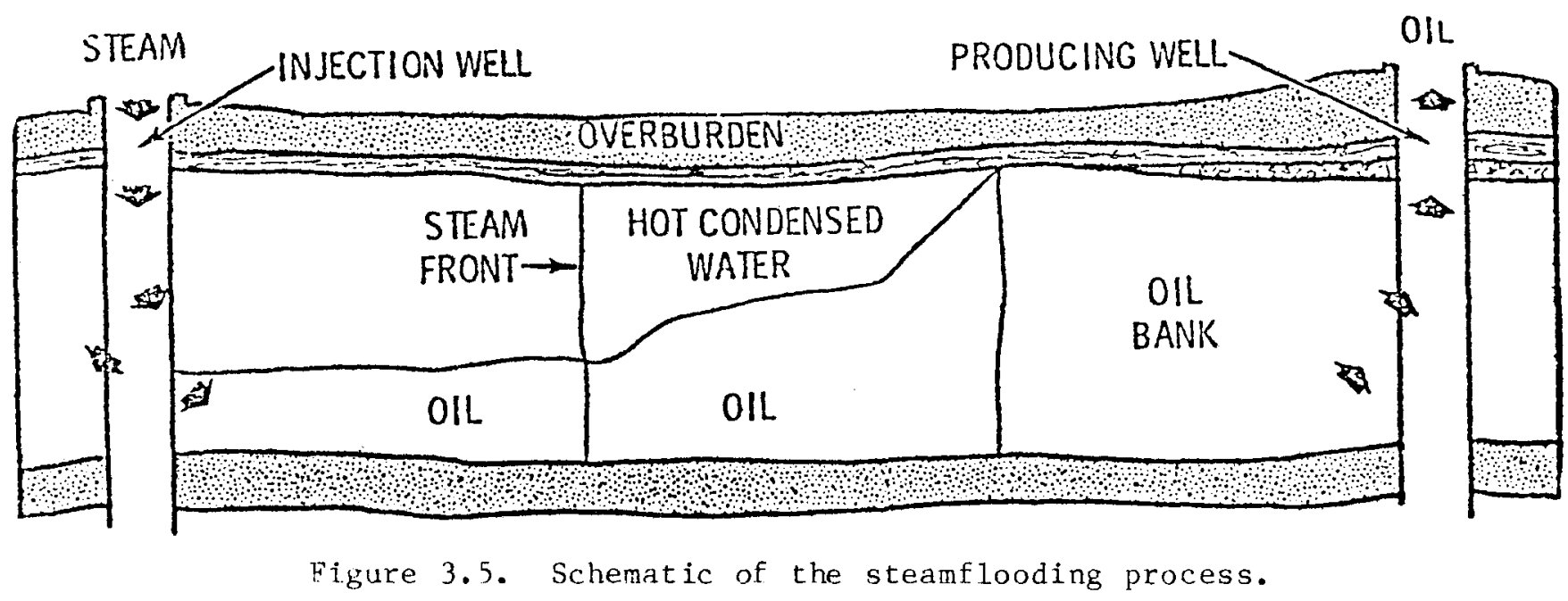

although there may be exceptions. As in any displacement process, such as waterflooding or steamflooding, continuity of the reservoir is required between pairs (injection-production) of wells.

\subsubsection{In Situ Combustion}

In situ combustion, also known as fireflooding, is the name applied to a broad category of recovery processes in which part of the crude oil is burned within a reservoir to produce heat. ${ }^{4}$ The heat of combustion partially vaporizes the remaining oil and reduces its viscosity. Separate production and injection wells are employed in this process. Normal1y, air is injected to support the combustion process. There are three types of in situ processes: dry forward combustion, counter current combustion, and wet combustion. The principal method now being used is COFCAW (combination of forward combustion and waterflooding). The wet or combination combustion processes were developed to maximize the temperature propagation within a given reservoir and to cut down on the net quantity of air which needs to be injected, as well as to maximize overall sweep efficiency. The wet combustion process is shown schematically in Figure 3.6.

The efficiency of in situ combustion is improved by the alternate injection of air and water. The water, as steam, transfers the heat left in the rock behind the burning zone to the rock immediately ahead of that zone, resulting in better heat distribution and reduced air requirements. The injected water also improves the mobility control, and thus the sweep efficiency, of the process.

In wet forward combustion, the amount of coke left behind to be burned as a fuel by the flame front is substantially decreased. More oil is thus displaced from the reservoir with less air required to burn a unit volume of the reservoir. Water injection in a ratio of 0.3 to 0.5 barrels of water per thousand cubic feet of air can reduce fuel and air requirements by as much as 30 to $50 \%$. The water-air ratio chosen moves the heat forward at about the same rate as the combustion front, while maintaining high combustion temperatures. Water can be injected with air at ratios of up to 1000 to 2000 


\section{OIL AND WATER}

\section{AIR AND WATER}
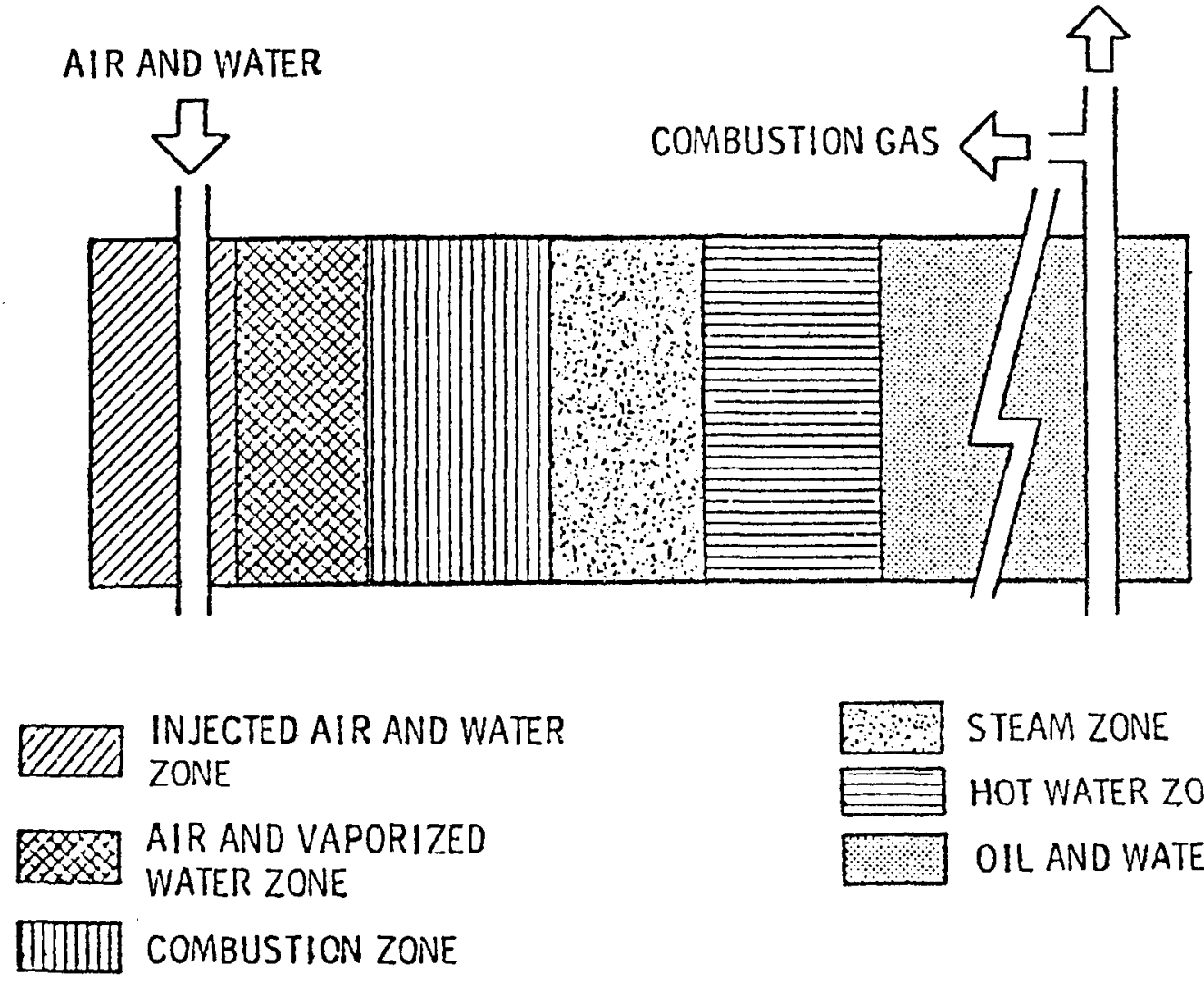

2 STEAM ZONE

HOT WATER ZONE

? OIL AND WATER ZONE

Figure 3.6. In situ combustion process - wet combustion.

scf of air per barrel of water without completely quenching the fire front. The injected water develops a steam zone in front of the combustion zone. The major benefit of the COFCAW process is that there can be a threefold reduction in the air required to produce one barrel of crude oil.

\section{REFERENCES}

1. Summary of Operation, California Oil Fields, Div. of Oil and Gas Production Statistics, Vol. 54, No. 2. Annual Reports for years 1959 through 1971.

2. B.G. Grant, and S.E. Szasy, Development of an underground heat wave for oil recovery, Trans. Soc. Min. Pet. Eng. AIME 201, 108 (1954).

3. C.A. Geffen, Tertiary Oil Recovery: Potential Application and Constraints, PNL- $\overline{\mathrm{RAP}-25,1978 .}$

4. C.S. Kuhr and R.L. Koch, In situ combustion, Oil Gas J., p. 91, August $10,1953$. 
This chapter discusses the prospects of technological advances to increase production of petroleum in the near term (15 to 20 years). Enhanced oil recovery is such a rapidly growing technology that the forecasting of recoveries and future production levels is difficult. However, a variety of areas with the potential for expansion of future production include:

- Downhole steam generation

- Fracture-assisted steam technology

- Other advances in steam injection methods

- Cheaper and more abundant $\mathrm{CO}_{2}$

- Mining of oil

- Advances in polymer research

- Microbial EOR

- Tar production by radio-frequency heating

Actual oil recoveries will be much greater than now predicted if rapid advances occur in any of these areas. Each of these possibilities will be discussed very briefly in this section.

\section{1 DOWNHOLE STEAM GENERATION}

Downhole steam generation may lead to a rapid expansion of steamflooding operations for two reasons. First, the current depth 1 imitation of 3000 feet on steamflooding operations may be removed, thus greatly increasing the number of potential reservoirs. Secondly, the need for controlling air emissions from surface steam generators would be reduced because combustion gases will be injected directly into the reservoir along with the steam.

Most experts believe that downhole stean generators will be useful in deep low pressure reservoirs possessing high permeabilities. They might also be useful in deep high pressure formations. Downhole steam generation eliminates most of the heat loss which occurs in the transportation of the steam. Thus, if a successful method is found for downhole steam generation, a number of new projects will begin which might increase the present estimates of tertiary oil production. $1^{1}$

Conventional steamflooding is limited to depths of 2500 to 3000 feet. Heat losses to the wellbore in deep formations consume too much steam to allow the process to be used below these depths. It is estimated that $15 \%$ of the steam's energy is lost when it is injected to depths of only 2000 feet. This loss of energy reduces the steam quality from 80 to $50 \%$ which is below the levels desired for economical steamflooding operations.

Because downhole steam generation is the process of generating the steam within the wellbore at the formation face, it has many obvious advantages:

- No heat loss during transmission

- Use of the heat contained within the combustion gases

- Reduction of environmental problems 
A downhole steam generator has been tested in several areas in California. Some of the tests have been successful. Other generators are now being tested in other California fields. Some technical problems of downhole steam generation include the plugging of the formation by ash and damage to the generator by sand. However, preliminary studies have indicated that these major problems are solvable.

Downhole steam generation offers exceptionally high thermal efficiencies while ameliorating air pollution by injecting the combustion gases into the formation. Future advances are required however, before this class of thermal recovery becomes economically and technically feasible.

\subsection{FRACTURE-ASSISTED STEAM TECHNOLOGY (FAST)}

This technique appears well suited to the recovery of oil from very lowgravity tar sands. ${ }^{1}$ A flat horizontal fracture is created from a single injection well using high pressure steam, and a rapid rate of steam injection keeps the fracture open. After the steam expands into the surrounding reservoi $r$, the fracture is allowed to close, and lower pressure steam then pushes the liquid tar toward the producing wells.

The FAST process aims to produce $50 \%$ of the residual oil in place in only one-third the time required for a conventional steamflood and has been applied with promising results to the Loco field (Stephens County, Oklahoma) and to the Saner Ranch (Maverick County, Texas). ${ }^{2}$

\subsection{OTHER ADVANCES IN STEAM INJECTION METHODS}

Many variations in the standard processes of cyclic steaming or steamflooding have been proposed and tried, and some have yielded encouraging results. A recent study ${ }^{3}$ shows that steamflooding should work well in light oil reservoirs and could conceivably be considered as an alternative to costly chemical flooding. Steam distillation yield is a key factor to determining the success of a steamflood in a light oil reservoir. Project success depends directly on the amount of ofl vaporized by steam heating. Texaco has operated a light oil steam drive in Shiell's Canyon (Ventura County, California) since 1973 and now plans two projects in Texas.

The use of foams and inert gases could also increase EOR in heavy oil projects by better mobility control and the prevention of steam breakthrough due to channeling and thief zones. Industry now appears to be solving the problems of developing a stable foam, according to recent reports. 1,4

Although not exactly a technological advance in the true sense of the word, the use of alternative fuels (rather than lease crude) in firing steam generators could immediately put up to one-third more tertiary oil in the marketplace, particularly in California. Solid fuels ranging from highsulfur petroleum coke to low-Btu lignite have been tested in fluidized-bed combustors with excellent results.5,6 A solar energy test using parabolic collectors is underway in the McKittrick Field (Kern County, California), and cogeneration systems and nuclear energy have also been proposed. 1 In fact, 
the potential for generating electric power in connection with cogeneration of steam for thermal EOR was recently evaluated. 7 The authors concluded that the potential electric power, if all the steam used in the process were cogenerated, is estimated to be between 10 and 17 GWe in 1985, assuming that most of the electricity would be generated from gas turbines.

\subsection{CHEAPER CARBON DIOXIDE GENERATION}

Carbon dioxide $\left(\mathrm{CO}_{2}\right)$ is demonstrably effective for use in EOR. Currently, its two drawbacks are availability and cost, which are potential limitations on the widespread usage of this type of recovery.

Carbon dioxide comes either from natural sources (reservoirs) or from exhaust gases of industries. Both of these sources can require expensive purification before the $\mathrm{CO}_{2}$ is suitable for injection into oil reservoirs. Current practices seem to favor the utilization of $\mathrm{CO}_{2}$ from reservoirs as the best and cheapest source. However, these reservoirs often require expensive and lengthy pipelines to bring the $\mathrm{CO}_{2}$ to particular oil fields. If costs can be reduced for $\mathrm{CO}_{2}$ and the availability problem is solved, the use of this gas could yield large amounts of additional tertiary oil. A recent proposal ${ }^{8}$ by scientists at Brookhaven National Laboratory indicates that the production of electricity using a $\mathrm{CO}_{2}$-diluted coal-oxygen process releases copious amounts of high-quality $\mathrm{CO}_{2}$.

\subsection{MINING OF OIL}

As pointed out previously, primary and secondary production leave large amounts of oil still in the ground, typically two-thirds of the estimated original oil in place. Tertiary (EOR) processes also leave much of the oil behind. Thus, at the conclusion of a successful recovery, there may be as much as a third of the original oil still left behind. The United States once had more than 460 billion barrels of oil in place. However, only about 148 billion barrels of that is considered to be recoverable by primary and secondary methods. That leaves 312 billion barrels as a potential target for other recovery processes. Some experts believe that it may be possible to recover almost half that amount by mining techniques.l

The two basic approaches used in the mining of oil are the traditional technique of strip mining (now used for Athabasca tar sands) and the less conventional technique (for oil) of shaft and tunnel mining.1,6 Strip or surface mining consists of three basic steps: overburden removal and disposal; ore mining and transport to a separation facility; and separation of the oil or bitumen from the sand. This technique represents a proven technology and its utilization depends only on cost effectiveness. As long as the oil sand contains sufficient bitumen and the overburden is roughly no more than twice as thick as the oil sand, this technique is feasible. It is now used commercially, primarily in Canada and California.

A large strip mining operation is beginning in California. One operator is spending $\$ 30,000,000$ on two pilot projects to mine oil in McKittrick 
field, California. One pilot will use a solvent extraction process, in which the mined diatomaceous rock is run through a series of tanks and the oil is dissolved by solvent. In the second pilot, the Lurgi (retort) process separates the oil from the rock. In both cases, the reservoir rock is first mined. No mining has begun yet. The operator hopes to eventually produce $26,000 \mathrm{~b} / \mathrm{d}$.

Shaft and tunnel mining for oil is essentially the same as shaft and tunnel mining for any other ore body. It entails drilling or cutting a main entry tunnel with secondary shafts going outward from the main tunnel. In this technique either the oil flows into a collection network or steam may be used (in site) to help it flow. This technique, sometimes referred to as a "fourth phase" of oil recovery, can be applied following conventional oil recovery operations. ${ }^{9}$

One very effective method of shaft and tunnel mining, known as drip drainage, can be used on any oil field that is shallower than about 1500 meters and underlain by competent (unfractured) rock. Drip drainage cannot be used at depths greater than 1500 meters because of the heat from the earth's interior. The process is begun by sinking a shaft into the rock which lies below the oil reservoir. Tunnels are drilled into the rock from the main shaft. Small holes are drilled into the reservoir at frequent intervals from these lateral tunnels. The oil then drains through these holes into the lateral tunnels and is pumped from there to the surface. Sometimes the process may be speeded up by slowly introducing water into the reservoirs either from the surface or from other tunnels above the oil reservoir. Some experts believe that as much as $50 \%$ of the remaining oil in place may be recovered by these techniques in fields whose depths are no greater than 2000 to 4000 feet.

The mining of surface rock outcrops for oil has been recorded since antiquity. This type of operation supported many small communities prior to the industrial revolution. Efforts to mine petroleum have been conducted in California, Kansas, Kentucky, Ohio, Pennsylvania, and Texas. Many of these efforts were reviewed in 1932. It was concluded that the techniques used then were technically sound but could not compete economically with conventional petroleum recovery methods. The situation was not the same elsewhere. Mining of outcrops has been done in Europe for some time. One such mine was opened in 1917 at Pechelbronn in the Alsace region of France. Germany began mining outcrops for oil in 1919 in the Wietze field near Hanover, where more than five million barrels of oil were obtained by 1950 . Japan has also used this technique to produce oil.

The Soviet Union has the largest oil mining operation in the world. It began in 1917 in the Yarega field, which is located about 1200 kilometers northeast of Moscow. This is a combined operation which also uses steam and the modified-drip drainage process. (Steam is needed here since this is a heavy oil reservoir and the oil has very low mobility under reservoir conditions.) The first mine had a production rate of just under one million barrels per year. The Soviets, now producing an annual 1.5 million barrels of oil from Yarega, plan to increase production to 6.7 million barrels and intend to use these methods in other reservoirs in the future. 
One current oil mining project in the United States, located in the Lakota field in Johnson County, Wyoming, produces about 50 barrels a day from an oil-bearing zone on a hillside outcrop. The operator has driven an adit directly into the reservoir and drilled five 600-meter holes further into the reservoir.

Petroleum mining generally has received a mixed reception among government officials. The Bureau of Mines is optimistic about its prospects. 10 It commissioned two reports on the subject and concluded that petroleum mining was a feasible operation that could produce a cumulative total of 200 billion barrels of oil.

\subsection{ADVANCES IN POLYMER RESEARCH}

Better polymers for surfactant-polymer floods and polymer floods could substantially increase EOR and make the economics of chemical floods more appealing as well. One such polymer, 11 a synthetic, has caused a production jump of $143 \%$ in 38 of 61 tests on unconsolidated sandstone and even a few carbonate reservoirs. This polymer appears more resistant to shear degradation (from high injection rates and/or reservoir brines) than conventional polymers, e.g., polyacrylamides.

In addition, some researchers at New Mexico Institute of Technology have treated polymer with acid and heat, 12 and have come up with compounds which are more effective ir increasing water viscosity in brine solutions up to 20,000 ppm. Brine-resistant polymers have long been sought after by industry; the advantages of using less of these expensive substances in chemical flooding are obvious.

\subsection{MICROBIAL ENHANCED OIL RECOVERY (MEOR)}

It has been estimated that MEOR has the potential of producing as much as 1.4 million b/d of tertiary oil by 1994,13 if workable microbes for EOR can be developed. However, a number of studies must precede the development of MEOR on anything more than a theoretical basis. To be viable for EOR, a microbe which breaks down oil components must withstand reservolr temperatures above $60^{\circ} \mathrm{C}$, salinities above 15,000 parts per million, and pH values down to 2. Such a microbe must be able to move through low-permeability formations (less than 1000 millidarcy), use sugar-based feedstocks or ofl as an energy source, reproduce in situ, and produce chemicals or gases that loosen the trapped oil.

Early investigation has aimed at genetic development of aerobic microbes which would satisfy the above requirements, but some researchers 14 now believe that pumping air into reservoirs to keep aerobic microbes alfve is not worth the effort. Hence anaerobic species may be more valuable than aerobic ones in the future. 


\subsection{TAR PRODUCTION BY RADIO-FREQUENCY HEATING}

The use of $r f$ heating to produce tertiary oil recently passed DOE-sponsored field tests 15 and has the potential of recovering 50 to $70 \%$ of residual tar in place, using about one barrel of equivalent energy for every three to five barrels of tar produced. Rf energy (similar to microwave cooking) from electrodes is used to heat a volume of tar sand, and heated oil is produced through gravity drive or subsequent surfactant flooding. In a recent field test, the Illinois Institute of Technology Research Institute 16 recovered $35 \%$ of the oil in place from some 60 tons of tar sands, and commercial-scale equipment should be capable of heating up to 20,000 tons in a single operation. Cost estimates were not given.

\section{REFERENCES}

1. R. Williams, New methods show promise to boost heavy oil recovery, Oil Gas J., pp. 17-21, August 1981.

2. Conoco process aims for low gravity tar sands, 0il Gas J., p. 22, June 1981.

3. Chevron study boosts light-oil steaming, Enhanced Recovery Week, p. 6, October 1981 .

4. 1980 Annual Heavy Oil/EOR Contractor Presentations - Proceedings, CONF-800750, DOE.

5. J. Davis, W. Young, and C. Lyons, Use of solid fuel possible for field steam generation, Dil Gas J., pp. 129-34, June 1981.

6. H.M. Wilson, California operators push production of heavy crude oil, Oi1 Gas J., p. 47, April 6, 1981.

7. R.M. Rodder and J.L. Boyde, Cogeneration Potential -- Enhanced Oil Recovery, EPRI-EM-1966, 1981.

8. F.L. Horn and M. Steinberg, A Carbon Dioxide Power Plant for Total Emission Control and Enhanced Oil Recovery, Brookhaven National Laboratory, BNL 30046, 1981.

9 Tetra systems looks to EOR's "Fourth Phase," Enhanced Recovery Week, p. 1 , November 30,1981 .

10. G. Rick, U.S. Bur. Mines Bull. 351 .

11. Synthetic polymer gets high marks, Enhanced Recovery Week, p. 7, September 1981.

12. Acid said to give polymers more punch, Enhanced Recovery Week, p. 1, August 1981. 
13. Use of microorganisms in enhanced oil recovery, Contracts for Field Projects, Progress Review No. 26, p. 138, DOE/BETC 81/2, March 31, 1981 .

14. Report outlines microbial EOR work, Enhanced Recovery Week, p. 1, September 1981.

15. Tar produced by radio frequency heating, 0il Gas J., p. 57, September 1981.

16. Illinois radio-wave technique awaits an investor, Enhanced Recovery Week, p. 4, September 1981. 
$\bullet$

$\theta$ 


\subsection{INTRODUCTION}

Many reports ${ }^{1-5}$ have addressed the potential environmental risks and impacts associated with various EOR technologies. Some of them have gone into greater detail than others, but most have succeeded in identifying and categorizing the environmental impacts of EOR and in qualitatively evaluating those impacts. The following chapter attempts a semi quantitative analysis of impacts based on possible U.S. EOR production scenarios described in Chapter 2.

\subsection{THE PROBLEMS}

of the many potential environmental problems associated with petroleum production in general, and with tertiary ofl production in particular (Table 5.1), most are solvable. Analysis shows that certain impacts are much more important than others for a given technology. Air quality problems, for example, seemingly outweigh all others in steamflooding because of the sheer volume of air pollutants produced from a typically large project. Should

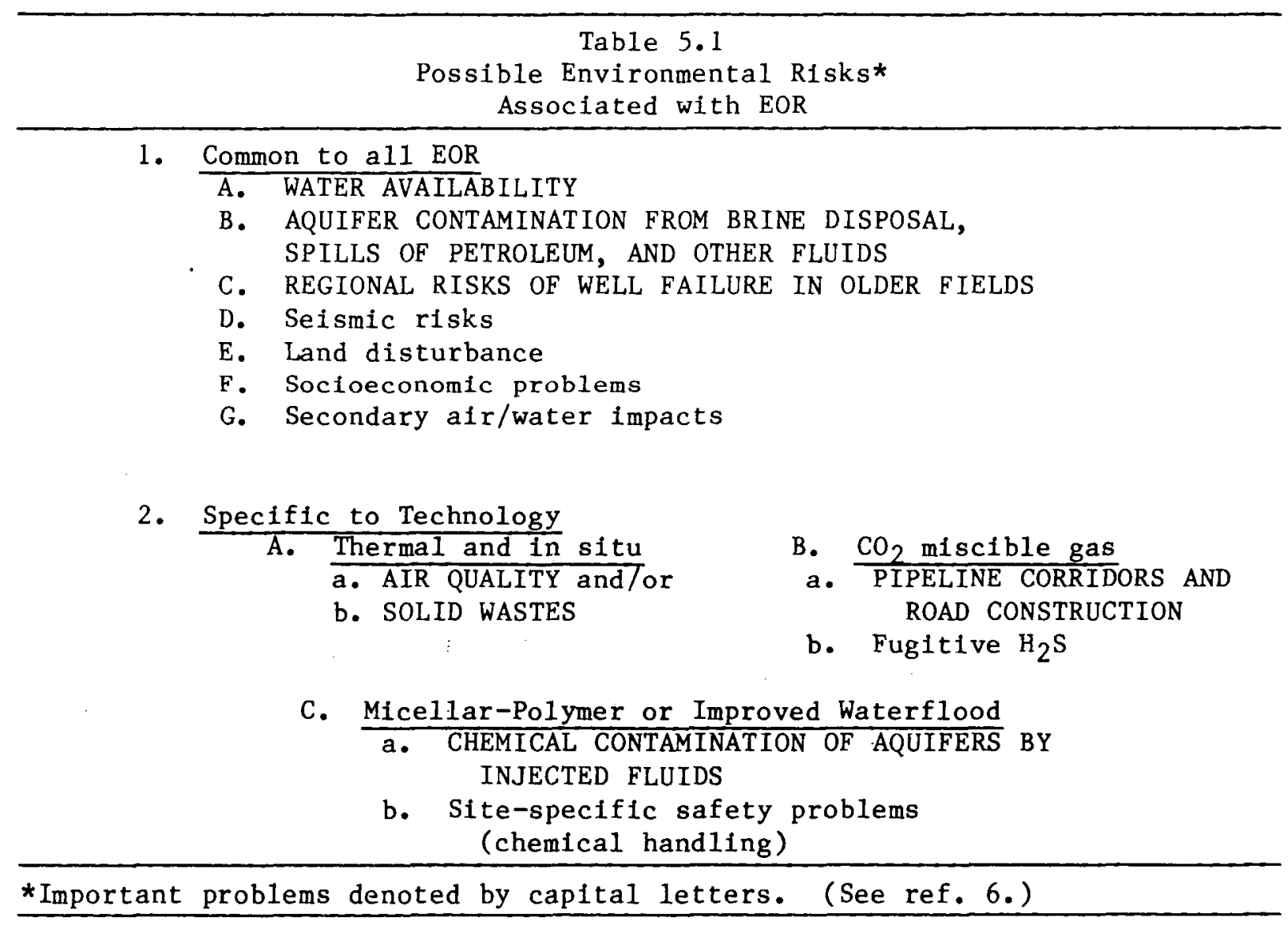


scrubbers and $\mathrm{NO}_{x}$ controls be put in place on steam generators in a steam field, however, $\mathrm{SO}_{\mathrm{x}}$ emissions would then be greatly diminished, to be replaced by solid waste (fly ash and scrubber waste) disposal as the major problem.

Carbon dioxide or miscible gas floods and micellar-polymer floods present problems involving specific reservoirs and possible communication between oil zones and aquifers. In relatively new fields where all wells have been meticulously logged and where all previously abandoned wells have been properly cemented, injection of fluids under pressure should cause little trouble; but, in older fields where these conditions may not obtain, aquifer contamination is a realistic concern.

These are only examples. There are, of course, fugitive or uncontrolled air emissions from in situ combustion projects and occupational health and safety hazards for workers exposed to irritating, toxic, or caustic chemicals, particularly on micellar-polymer, caustic, and polymer floods. Brine disposal is a problem common to all oil recovery operations, particularly important in tertiary projects for which the ratio of produced water to produced oil can run as high as 10:1 or more. Because produced fluids are often utilized if their salinity is low and if their chemical makeup is appropriate, the ratio of fluids actually disposed of to produced oil will vary even more. In the Kern River field in California, for example, only about $14 \%$ of the produced freshwater is disposed of, and the overall Kern County ratio for disposed water to produced oil is approximately $4: 1$.

Finally, all EOR operations require water. Wherever the water consumed and the water required are of the same magnitude, the question of supply becomes extremely important. Although it has been indicated that no EOR project to date has ever been abandoned because of water supply problems, 6 competing regional uses for water, drought situations, and scarcity of highquality (e.g., low total dissolved solids) surface and ground water could be impediments to certain projects in the near future.

Land disturbances, secondary impacts, and socioeconomic effects certainly bear consideration, but this report considers these as lesser issues compared to air and water problems. Issues associated with general petroleum production such as the use of chemicals for well cleaning and treatment, and the disposal of drilling muds will be discussed principally in the context of their incremental use in tertiary recovery.

\subsection{REGIONAL ENVIRONMENTAL ISSUES}

Figures 5.1 through 5.6 illustrate the various EOR technologies now used in the United States. It is clear from this variation that each region has its own important issues (in addition to brine disposal and water availability which ought to be considered important in many places across the entire nation).

Steamflood and steam soak are currently the dominant EOR technologies in California and are expected to remain so for the next 20 to 40 years. Air quality and solid waste disposal are therefore of major concern in that 


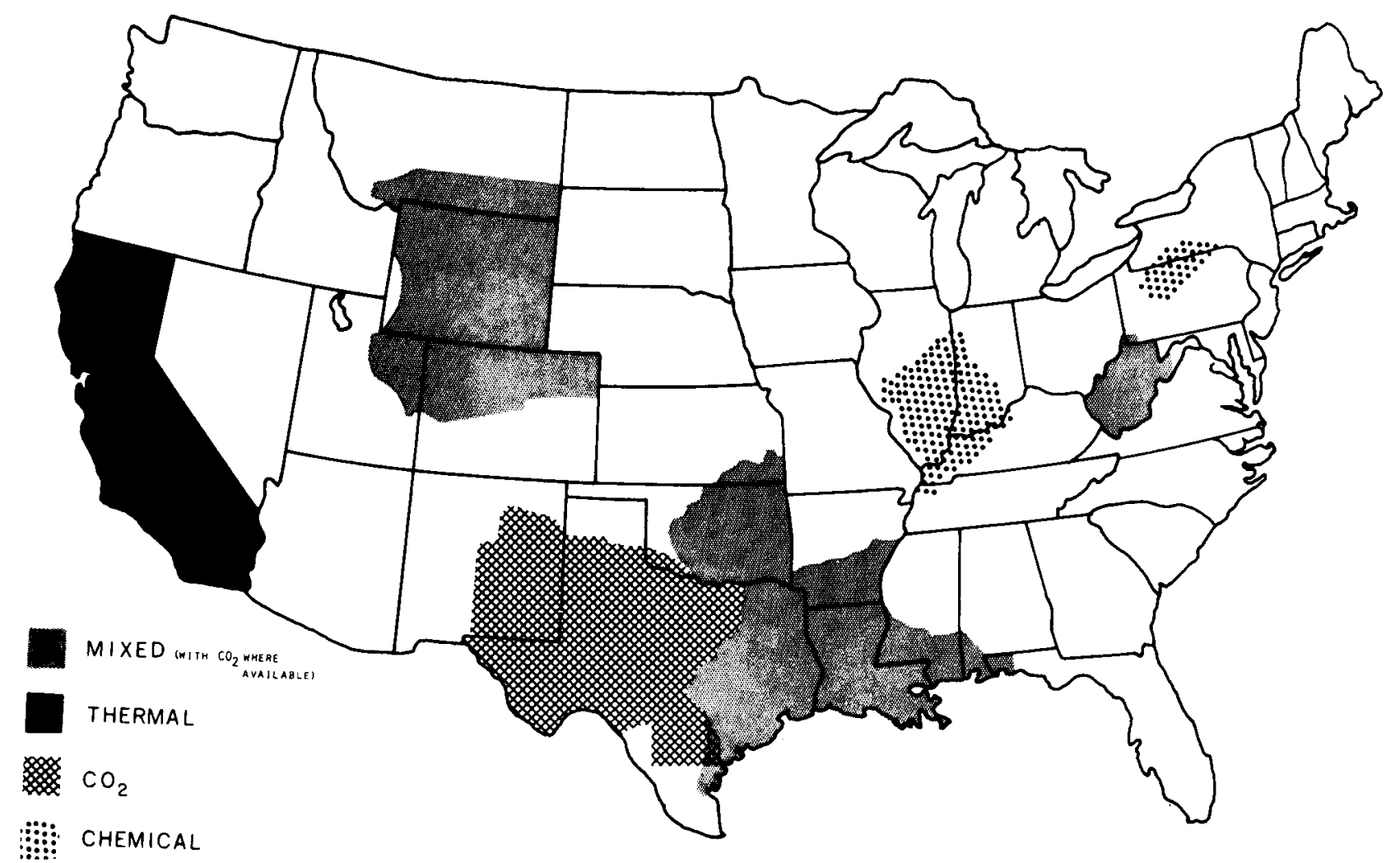

Figure 5.1. Regional EOR in petroleum provinces of the United States.

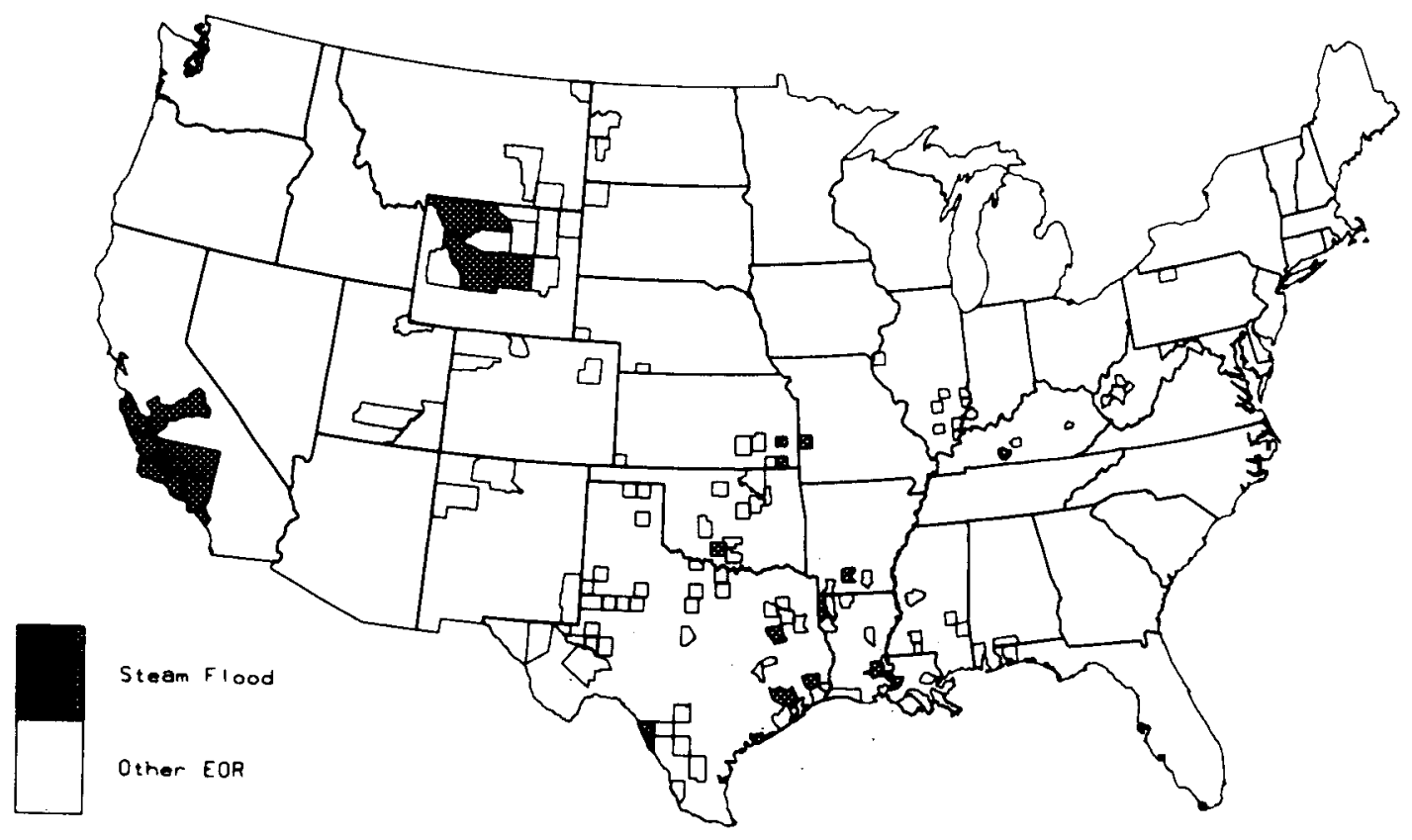

Figure 5.2. Fields where steam flood or cyclic steam or steam in combination with other methods is, has been, or is expected to be applied. 


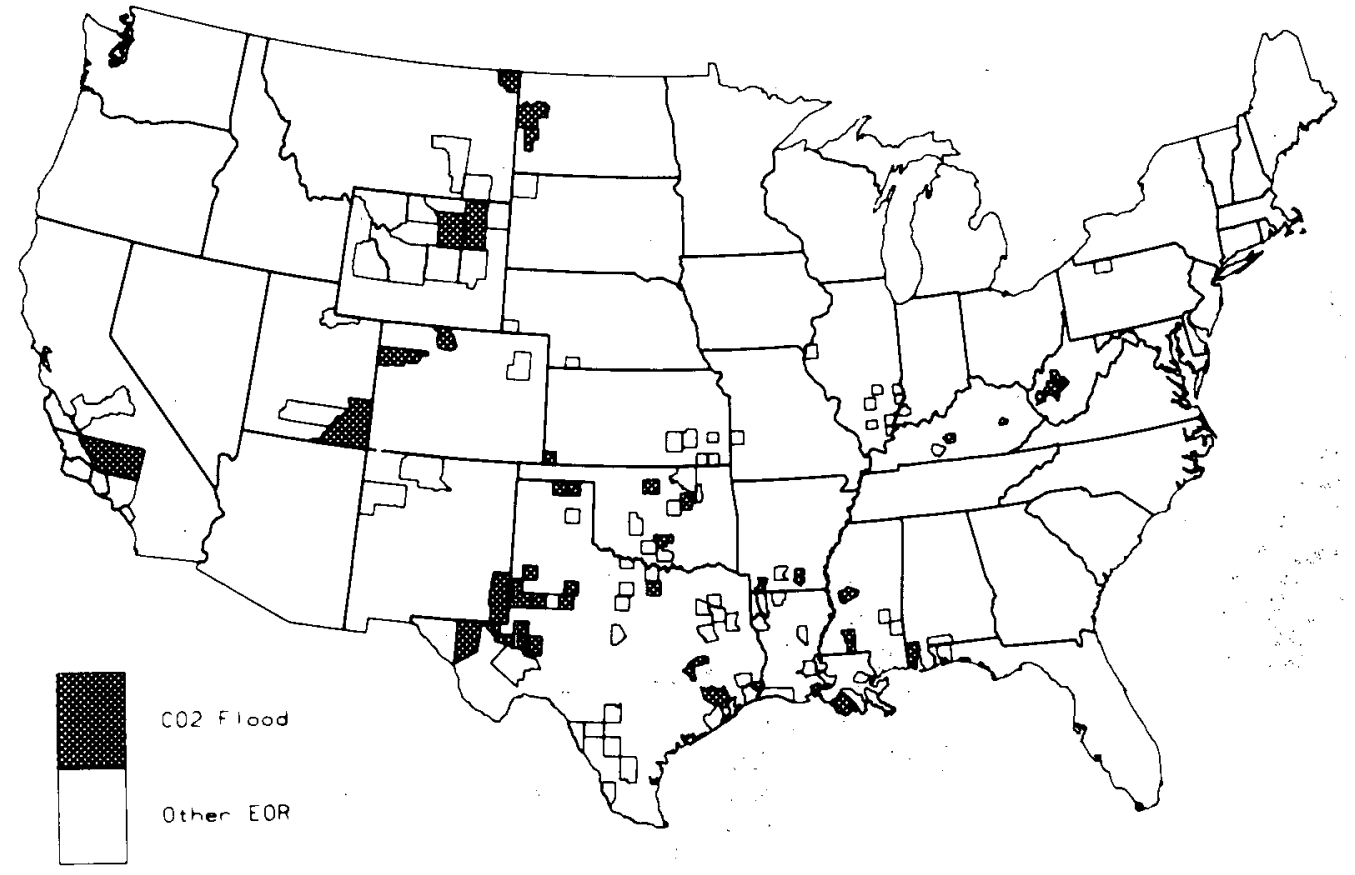

Figure 5.3. Fields where $\mathrm{CO}_{2}$ flood is, has been, or is expected to be applied

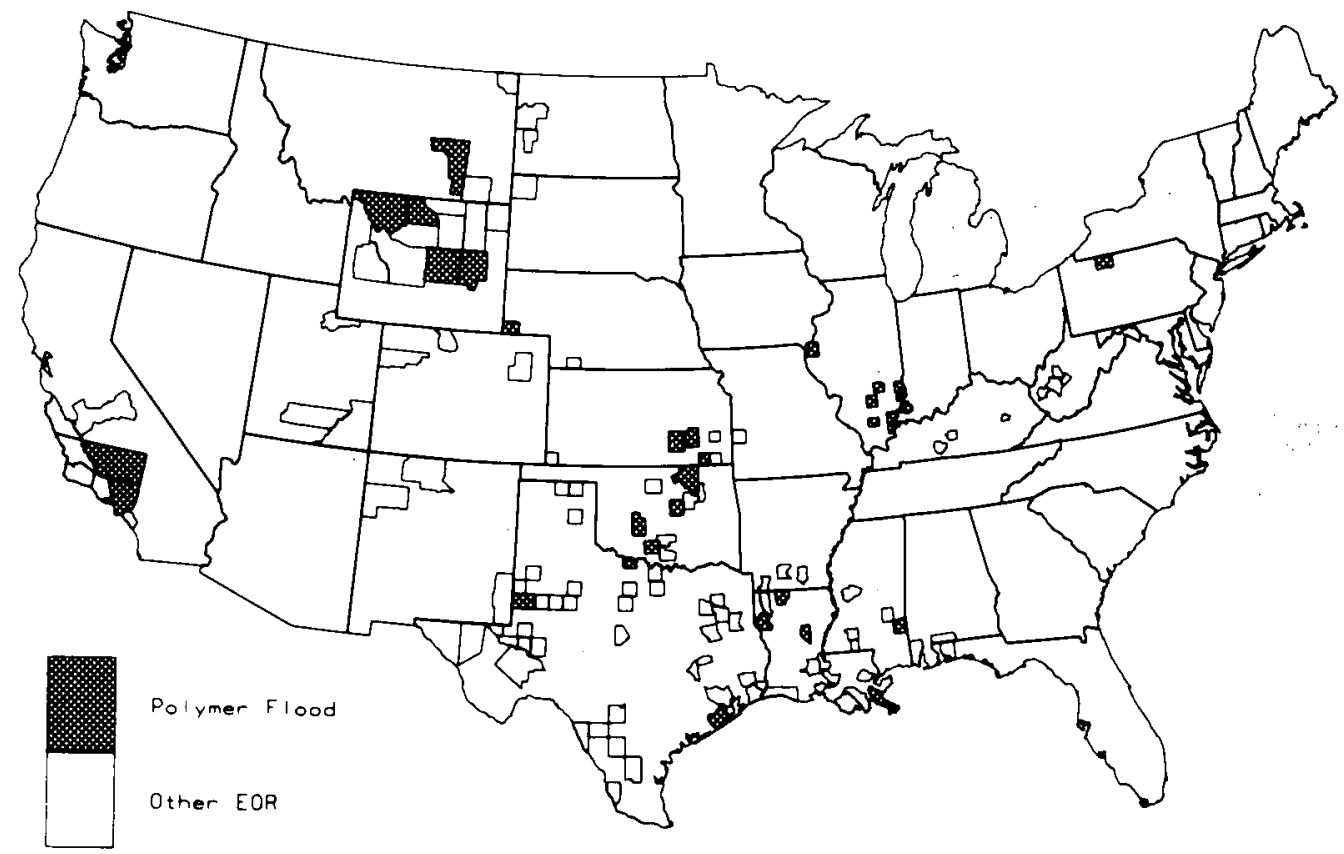

Figure 5.4. Fields where surfactant (micellar-polymer) flood or polymer flood is, has been, or is expected to be applied. 


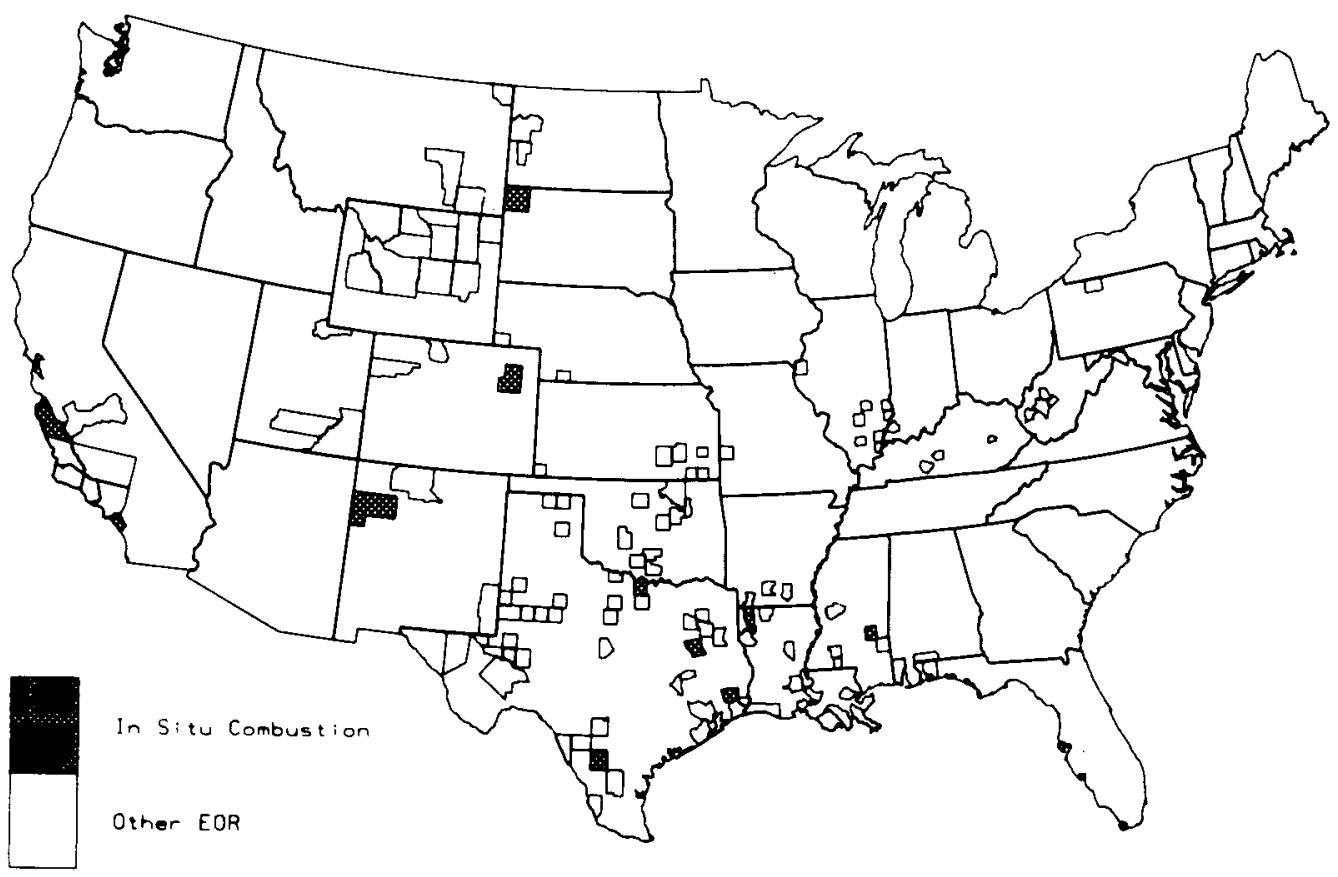

Figure 5.5. Fields where in situ combustion is, has been, or is expected to be applied.

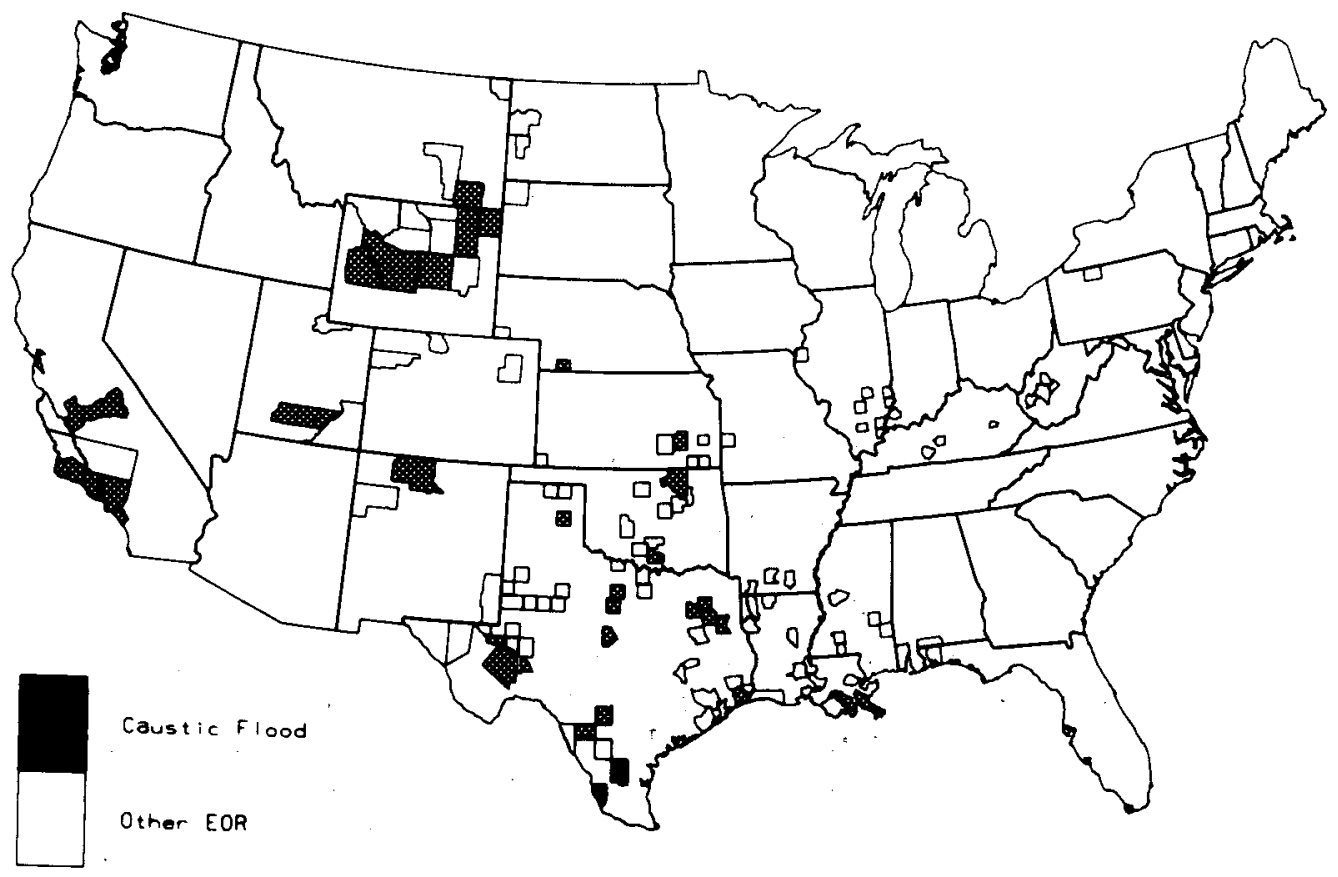

Figure 5.6. Fields where caustic flood is, has been, or is expected to be applied. 
state. In the Gulf Coastal region, $\mathrm{CO}_{2}$ use represents a fairly problem-free technology which presents few environmental risks, except for brine disposal and pipeline construction. When compared to other EOR technologies, miscible gas requires fairly small amounts of water which are generally recycled. However, in regions where several different technologies include micellar-polymer, caustic, and polymer floods, large amounts of freshwater will be consumed; this could produce dramatic conflicts where water rights are hotly contested.

Chemical floods of any sort appear risky in certain older fields in the Eastern United States (the Appalachian region), simply because of the large number of abandoned, unlogged wells per acre in those locations. The spectre of unplugged, abandoned, unlogged wells haunts EOR production for Pennsylvania and West Virginia fields, where the risk of aquifer contamination from migrating fluids is particularly high.

Offshore EOR and Alaskan EOR present peculiar environmental hazards, mentioned only briefly because a detailed discussion is beyond the scope of this report. Offshore wells using $E O R$ might require special precautions in the transportation of $\mathrm{CO}_{2}$ and other chemicals and in chemical or oil spillage. Still, some of these problems are similar to those encountered in primary production from offshore platforms, even though the particular chemicals handled are different for tertiary recovery operations.

Alaskan EOR, most likely using available $\mathrm{CO}_{2}$, would entail an incremental increase in oil field activity in the sensitive tundra environment where any activity is cause for concern. Alaska might therefore be one of the few places where land disturbance would become the major problem rather than a secondary one.

\subsection{MITIGATION OF IMPACTS: CONTROLS AND REGULATIONS}

It has often been claimed that existing or new regulations adequately address the problem of environmental protection in EOR. A more complete discussion of EOR regulations is contained in ref. 7 , and only a brief summary is presented here. It should be noted that several applicable regulations, such as those related to the Clean Air and Clean Water Acts, may be undergoing change at this moment because of Congressional oversight hearings.

The Clean Air Act (42 U.S.C. $\$ \$ 7401-7642$ ) as amended in 1977 and 1981 governs emissions, according to the various State Implementation Plans (SIPs), which attempt to keep air quality within the limits set by National Ambient Air Quality Standards. In the next section, the extent to which thermal and in situ production contribute to air pollution in the California region is discussed. However, the New Source Performance Standards are rather strict in California because of State regulations imposed by the California Air Resources Board, and it is anticipated that most thermal operations need emission controls (flue gas desulfurization, nitrogen oxide controls, etc.). The reduction from uncontrolled emissions to controlled emissions will be dramatic. 
The underground injection control (UIC) program, which is derived from a directive in the Federal Safe Drinking Water Act (S.1421,42 U.S.C. $\$ \$ 300 \mathrm{~h})$, is an extremely important set of regulations for EOR. During 1979, EPA proposed technical 8 and procedural ${ }^{9}$ requirements for issuing injection control permits; and most of the states with EOR in progress are now in the process of obtaining primacy for issuance and administration of injection control regulations. In theory, UIC regulations in most states, if properly enforced, should prevent groundwater contamination from chemicals used in EOR and from brines generated in petroleum production, but enforcement of regulations is a major problem. Because of conflicts between those agencies charged with promoting petroleum production and those charged with protecting groundwater resources, documentation of groundwater contamination is extremely spotty. There are indications, though, especially in the Southwest and the East, that brine disposal wells have been the source of substantial aquifer contamination in the past. This is discussed in detail later in Section 5.6.2 and in Appendix A on groundwater contamination.

If the air quality problem turns into a solid waste management problem (e.g., in California fields, where strict emission controls result in copious amounts of scrubber wastes), regulations of the Resource Conservation and Recovery Act [42 U.S.C. $\$ \$ 6901-6987$ ] apply, depending on how EPA decides to classify scrubber wastes. Even if such wastes are not classified "hazardous," the difficulty of simply finding adequate landfill space remains for both EPA and the state agencies.

Spills and spill prevention are regulated according to the Clean water Act [33 U.S.C. \$ 1251-1376] with regard to facilities from which oil can enter U.S. waters 10 and according to EPA rules on spills of hazardous substances.li Attempts to evaluate the toxicity, carcinogenicity, or mutagenicity of all chemicals used in petroleum production are still in progress, but many of the chemicals tested by these analyses may have little or no application for EOR. Nevertheless, it is likely that some EOR facilities will be required to adopt "best-management practices" to prevent runoff, drainage, or spills of certain chemicals. These best-management practices will probably be implemented through National Pollutant Discharge Elimination System permits, administered by EPA.

The direct effects of the above-mentioned environmental regulations on commercial production are unknown, but it is assumed here that they will not alter the production scenarios on which this environmental assessment is based. Clearly, there will be costs related to pollution control. However, an analysis of what these costs might be and their effects on expected production is beyond the scope of this study.

\subsection{SCALING IMPACTS TO PRODUCTION. BASES.}

Estimates of most of the parameters necessary to predict environmental impacts are made from the production levels in the scenarios described in Chapter 2. Among these parameters are air emissions (tons/yr of pollutants), brine production, solid wastes (assuming emission controls), water requirements, and chemical requirements. 
Actually, some choices between the production levels of Scenarios $A$ and $B$ are necessary in order to develop a meaningful environmental scenario. For example, where a field is small [e.g., where its Estimated Tertiary Increment (ETI) produced over 40 years and defined according to Chapter 2 would be less than $500 \mathrm{~b} / \mathrm{d}$ average for thermal, miscible gas, and micellarpolymer floods or less than $100 \mathrm{~b} / \mathrm{d}$ (average) for a polymer or caustic flood] the chances for fieldwide production are quite good. In such a case, the maximum b/d production becomes an important number on which to base estimates of air emissions, water requirements, quantities of disposed brines, etc. The maximum $\mathrm{b} / \mathrm{d}$ can be calculated 12 from the ETI by using the following approximate multipliers: 1) ETI $x 0.22 / 365$ for steam and in situ; 2) ETI $x$ $0.1 / 365$ for $\mathrm{CO}_{2}$ and miscible gas; 3) ETI $\times 0.32 / 365$ for micellar-polymer; and 4) ETI $x 0.2 / 365$ for caustic and polymer floods.

Accordingly, calculations were made for maximum b/d production from "sma11" fields and from larger fields which are undergoing full-field development. Comparisons were made between Scenario A production (A), Scenario B production (B), and Maximum production (MAX). For large fields undergoing stepwise development, comparisons were made between $A$ and $B$ only. Logical choices were then made for production figures used to develop the environmental scenarios, according to Figure 5.7. Calculation of water requirements, brine production, air pollutants, and solid wastes then followed from the oil production figures ${ }^{1-5}$ and the scaling factors.

For example, a typical steamflood might require seven barrels of water for every barrel of oil produced, and the barrels of brine produced and ultimately disposed of might be approximated as $75 \%$ of the water required. Hence oil production figures can be used in a rough fashion to scale parameters for environmental scenarios. Such figures were calculated on a field-by-field and county-by-county basis for all the flelds 1isted in Table 2.1. Accordingly, the scaling factors of Table 5.2 were used in conjunction with estimated EOR production figures to produce the maps of water requirements in Section 5.6.1, Figures 5.12 and 5.13. Likewise, air emissions scenarios similar to the one displayed in Table 5.23 can be derived by applying the scaling factors found in Tables $5.11,5.13,5.18$, and 5.19 along with est1mated EOR production figures.

Naturally, the estimates of environmental parameters are no better than the ofl production estimates, and, as stated earlier, the estimated tertiary increments from which the production estimates must be derived are often good to within a factor of 2 at best. Nevertheless, the estimated parameters are reasonable numbers for productive fields. More realistic production scenarios might be derived from expanded data bases like those now being developed by Petroleum Data System and the Bartlesville Energy Technology Center. In certain cases, it ought to be possible to get more accurate numbers for the parameters necessary to predict environmental impacts. For example, where field operators supply figures for target oll from private communication or in industry publications and also give development schedules for the projects as well as figures for expected volumes of injection fluids and produced brines, the environmental impact parameters can be determined more precisely. 


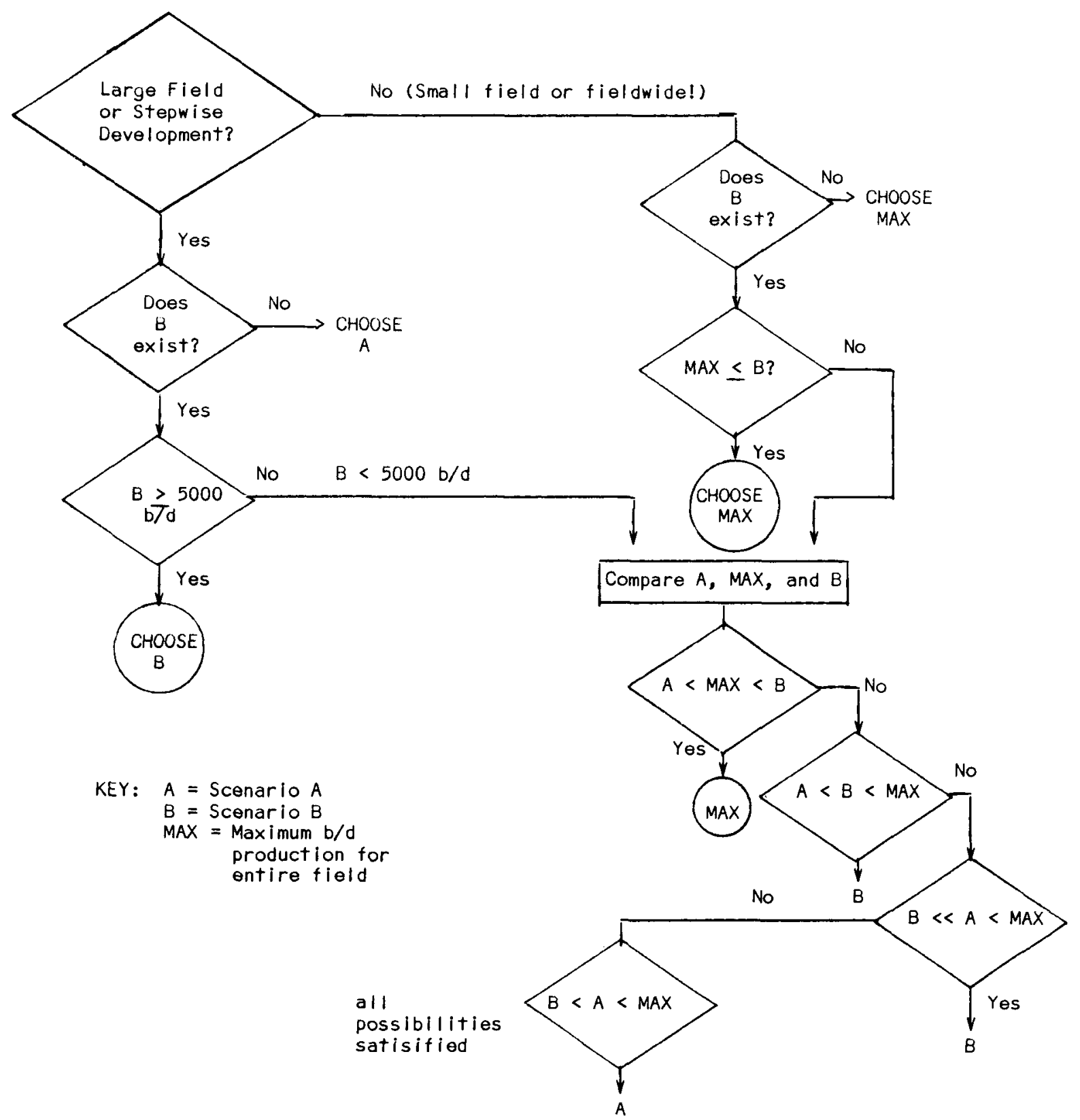

Figure 5.7. Choice of production figures for environmental scenarios.

As EOR projects expand to more fields, new areas and counties will be affected, but the same scaling factors can be applied to their estimated production figures to generate parameters necessary for assessment of potential environmental impact. Because most of the fields not considered here will be small (less than 5000 b/d production), their wastes and their requirements will usually be moderate when considered in terms of the overall national picture. However, the local impacts might still be important and, of course, many small contributions can add up to a significant total.

Because the sheer numbers of EOR projects are expected to expand rapidly within the next two: decades and because technological improvements such as downhole steam generation and use of saline fluids in chemical EOR techniques could alter the picture of environmental impacts drastically, this report 
should not be viewed as the ultimate assessment. However, it is the best quantitative assessment possible at this time, subject to current limited knowledge and data.

\subsection{WATER IMPACTS OF ENHANCED OIL RECOVERY}

Groundwater quality has become a major concern in recent years. Aquifers have been used as repositories for industrial waste without due consideration to their regenerative capacity. Groundwater flows quite slowly (typically, measurements are in feet per year). Aeration and biodegration, important self-purification mechanisms in surface streams, play reduced roles in groundwater decontamination, which, moreover, may not be detected for many years.

Overdraft and deteriorating quality are the two major problems associated with groundwater use in many states. Groundwater overdraft is caused by removing or "mining" groundwater faster than it can be naturally recharged. Large overdrafts are common in the central and south central parts of the country (see Figure 5.8), and in parts of central California and the Gulf Coast. Often these overdrafts are accompanied by land subsidence.

Groundwater contamination from pollutant releases occurs nationwide and is particularly important where drinking waters are affected (see Figure 5.9). Groundwater overdrafts can increase the risk of contamination. Any pollutant releases can further exacerbate the situation. Contamination can occur because of improper oil and gas field operations, improper disposal of toxic wastes, leaching of landfills, runoff of irrigation waters, improperly completed injection wells, and natural or induced saltwater intrusion into groundwater aquifers. Along the Southern California coast, seawater intrusion and irrigation return flows are two major problems. In the South Central region, groundwater generally has a high salt content; overdrafts have resulted in water so brackish as to terminate some agricultural activity in the Trans-Pecos area of Texas. 13

Enhanced oil recovery could add to these overdraft and contamination problems. If leakages occur, or if water is in short supply, EOR might result in significant local problems in several counties in the U.S. At present, tertiary recovery is planned in over 90 counties from California to Pennsylvania. Section 5.6.1 examines questions of groundwater contamination, how widespread the contamination could be, how much water would be needed for EOR, and the availability of sufficient water. Section 5.6 .2 looks at groundwater contamination from the injected chemicals, brines, and other materials associated with EOR.

\subsubsection{Water Requirements}

Water requirements depend on the EOR technology used (Table 5.2). The quality of water required for oil recovery can vary among the technologies and even within a technology for specific types of processes. It should be noted that these water requirements are total volumes injected, not necessarily consumptive use. More recent estimates have been made by Collins 14 


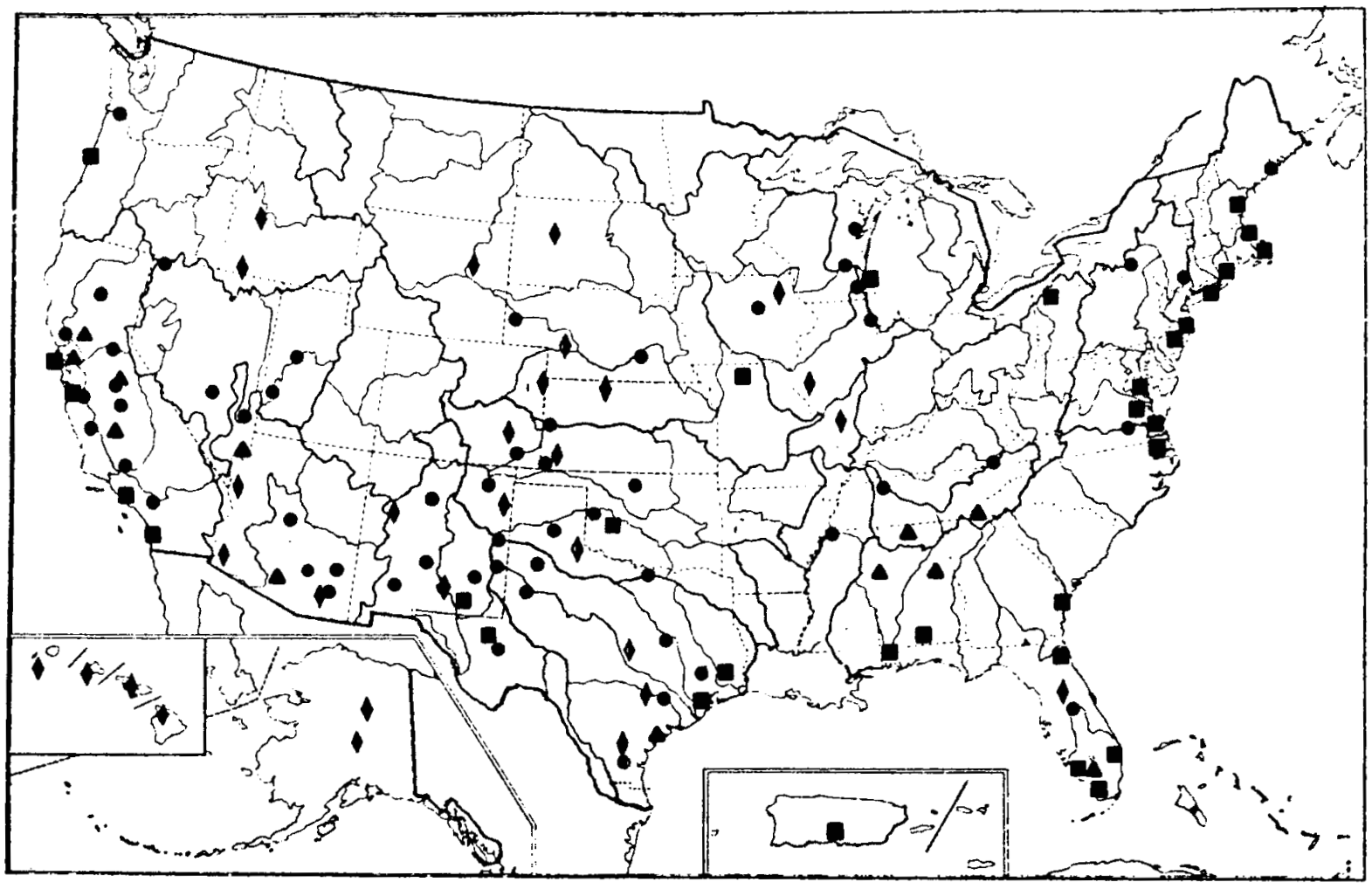

Explenation

Aree problem

Area in which significant ground-water overdratt is occurring

Unshaded area may not be problem-free, but the problem was not considered major

Spocific probliom (as identified by Federal and Staze/Regional study teams)

- Declining ground-water levels

- Diminished springtiow and stroumflow

- Formation of fissures and subsidence

- Saline-woter intrusion into fresh-water oquifers

Boundaries

Water resources region

Subregion

Figure 5.8. Groundwater overdraft and related problems (ref. 23).

Table 5.2

Water Requirements for EOR in bbl of Water per bbl of Tertiary Oil Produced

\begin{tabular}{lr} 
Steam soak & 7 \\
Steam drive & 7 \\
Improved waterflood & 10 \\
$\mathrm{CO}_{2}, \mathrm{~N}_{2}, \mathrm{HC}$, miscible & 4 \\
Caustic & 10 \\
Micellar-polymer & 10 \\
In situ & $<1-5.5$ \\
\hline
\end{tabular}



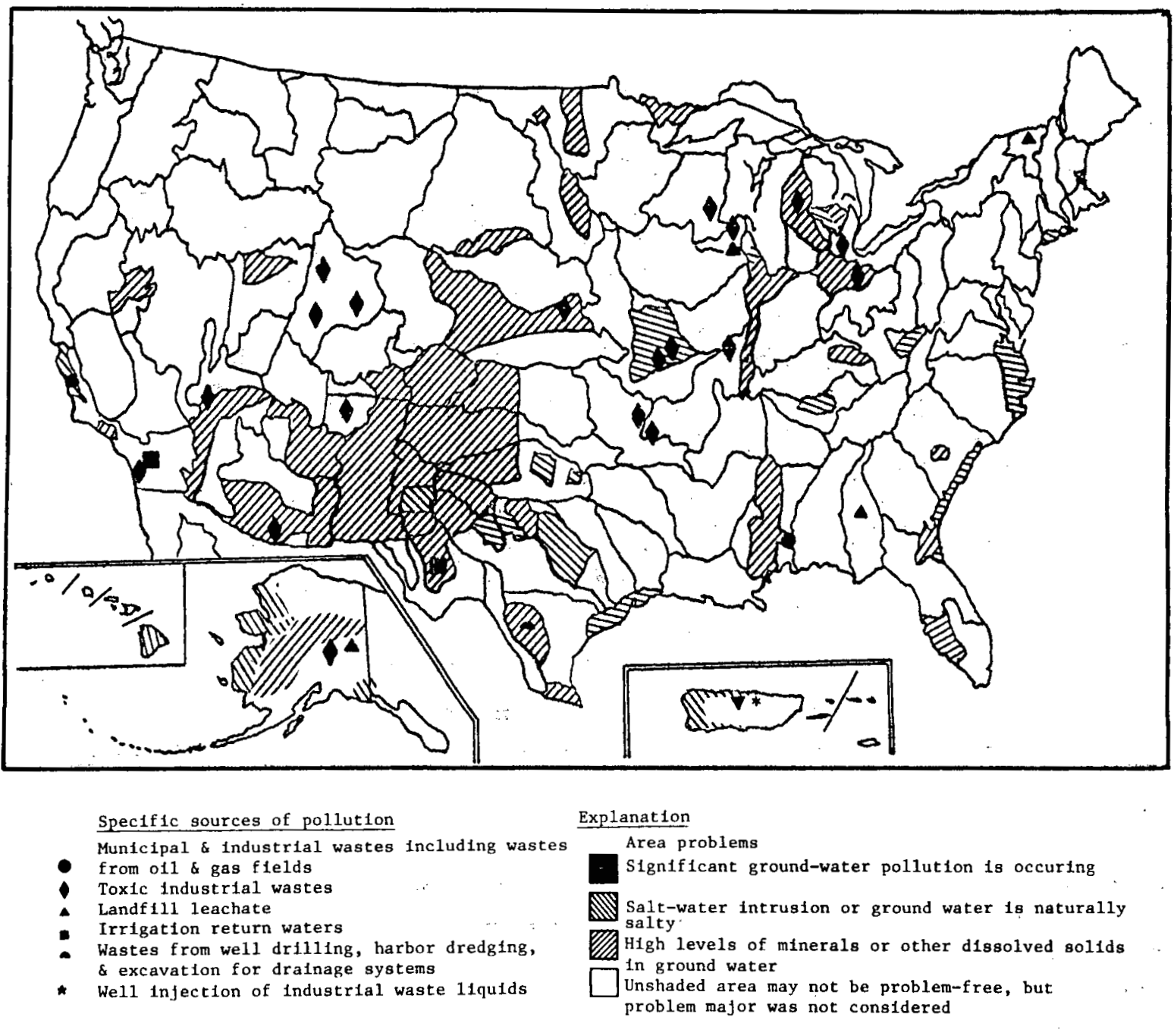

Boundaries

Water resources region Subregion

Figure 5.9. Groundwater pollution (ref. 13).

and by the Mittelhauser Corporation, 15 but these were not available at the time our data were in preparation.

For steam injection, water requirements depend on the reservoir characteristics and the type of steam injection process used. Water usage is generally expressed as the ratio of steam injected to oil produced. It varies from 4 to $10 \mathrm{bbl}$ of water per bbl of oil produced. For cyclic steam injection, the water requirements are lower and vary during the life of the project.

In $\mathrm{CO}_{2}$ injection, processed water is required to reach and maintain desired reservoir pressure and to mix with $\mathrm{CO}_{2}$. The first requirement is 


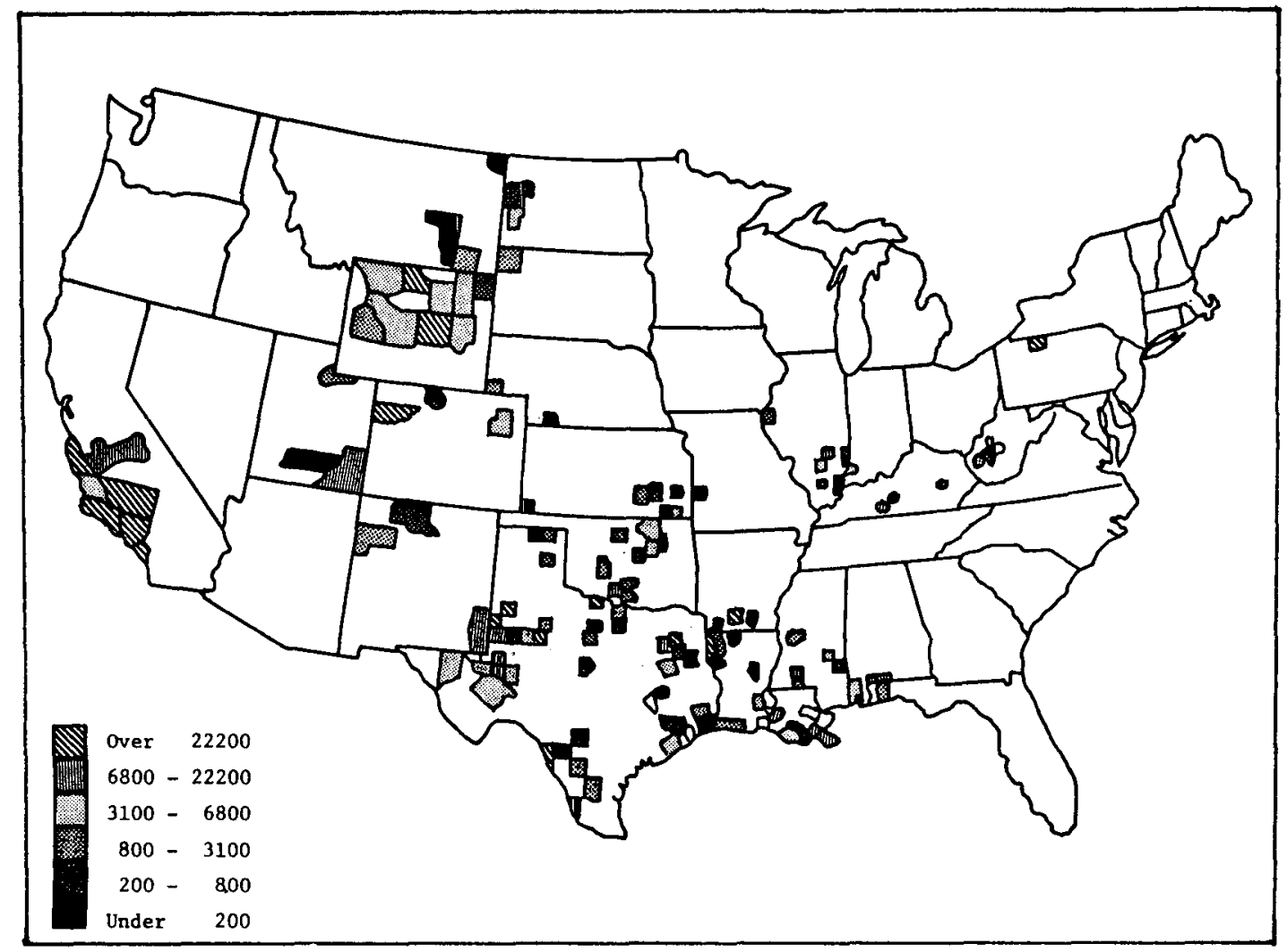

Figure 5.10. Average enhanced oil production by county as projected for the year 2000 in units of barrels per day.

reservoir specific, whlle the second depends on the amount of $\mathrm{CO}_{2}$, usually in the range of 20 to $30 \%$ of the hydrocarbon pore volume.

Water requirements for micellar-polymer projects may be as much as 20 bb1 of water per bb1 of oil, but will probably decline as the process is improved.

Figure 5.10 shows the oil production projected for the year 2000, and Figure 5.11 shows the corresponding water requirements by county based on the projected EOR production levels for each field. These requirements are based on the 40-year average production levels.

\subsubsection{Water Sources}

There are three main sources of water used in EOR: (1) produced water, (2) surface water, and (3) groundwater.

Water is produced with oil, generally in large quantities. Not uncommonly, $90 \%$ or more of the fluid in producing oil fields is water. A survey by the California Division of $0 i 1$ and Gas shows produced waters ranging from 80 to $93 \%$ of total production. 16 In theory, this constitutes a large resource available for reinjection to the formation. The fraction of this 


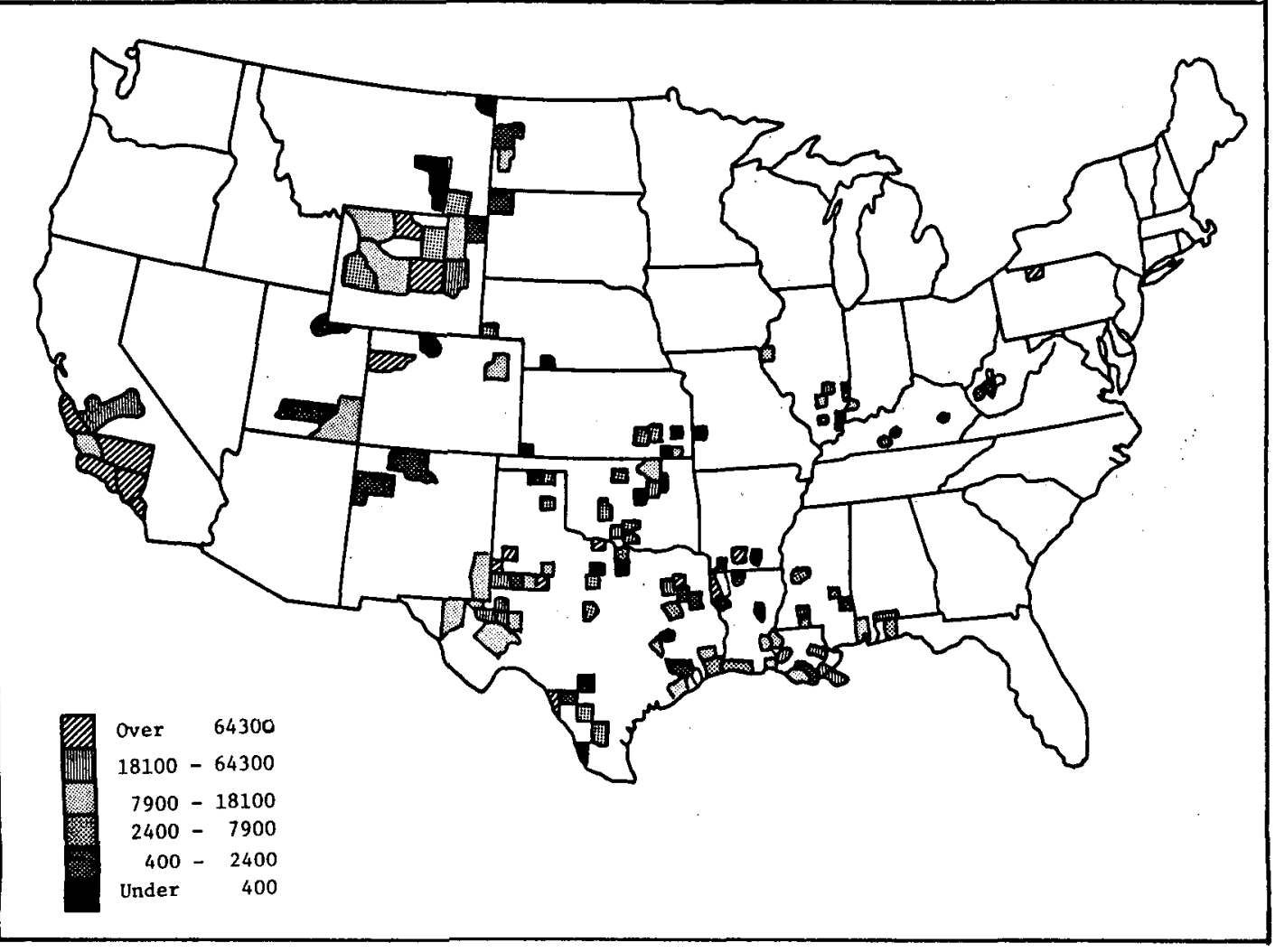

Figure 5.11. Average water requirements for enhanced ofl recovery as projected for the year 2000 in thousands of barrels of water per year.

water which will be reused in a field depends on its quality, the costs of its treatment, and the availability of other water alternatives. $\mathrm{CO}_{2}$ injection, in situ combustion, and some phases of micellar-polymer processes often use produced water without treatment. Boiler feedwater for steam injection may require extensive pretreatment of produced water.

Surface water for EOR is often transported many miles from its source. In California, fields on the west side of Kern County obtain water from the California Aqueduct several miles away.

Pumping of groundwater is another means of acquiring injection water. Poor groundwater quality and water use conflicts in many areas may make this an undesirable alternative.

During the past several months legislation has been introduced in the Oklahoma Congress to prohibit the use of fresh groundwater for EOR by defining such use as waste. Another amendment was introduced which would allow groundwater use for EOR without the "waste" approbation, but only up to a prescribed limit. These deliberations resulted from a case brought by residents in the Oklahoma Panhandle against an oil company. Although the company owned water rights to 3442 acres of land in the Oklahoma Panhandle, its use 
of these freshwaters was challenged by a district judge because the waters were held to be limited resources shared by the landowners.

Wherever water resources are scarce, alternative development options are being proposed. These alternatives include the reuse of waste waters, the recycling of water from the field after additional treatment, and the use ocean waters when found close to the field.

Produced water is the most accessible source of water for EOR projects. In the Kern River field in Kern County, California, the quality of the produced water is exceptionally good and can supply all the water requirements for injection in a large part of the field. Some of the water is made available for agricultural development and subsequently treated for use by the city of Bakersfield for domestic purposes. The quantity of produced water depends on the reservoir characteristics and the age of the field.

It is not possible to identify the exact amount of produced water that will be reinjected into an oil field except on an ad hoc basis. Produced water quality and the treatment process available at the time will determine the requirements for additional water. Figure 5.12 shows the estimated amounts of water required for EOR injection in the year 2000. Counties with

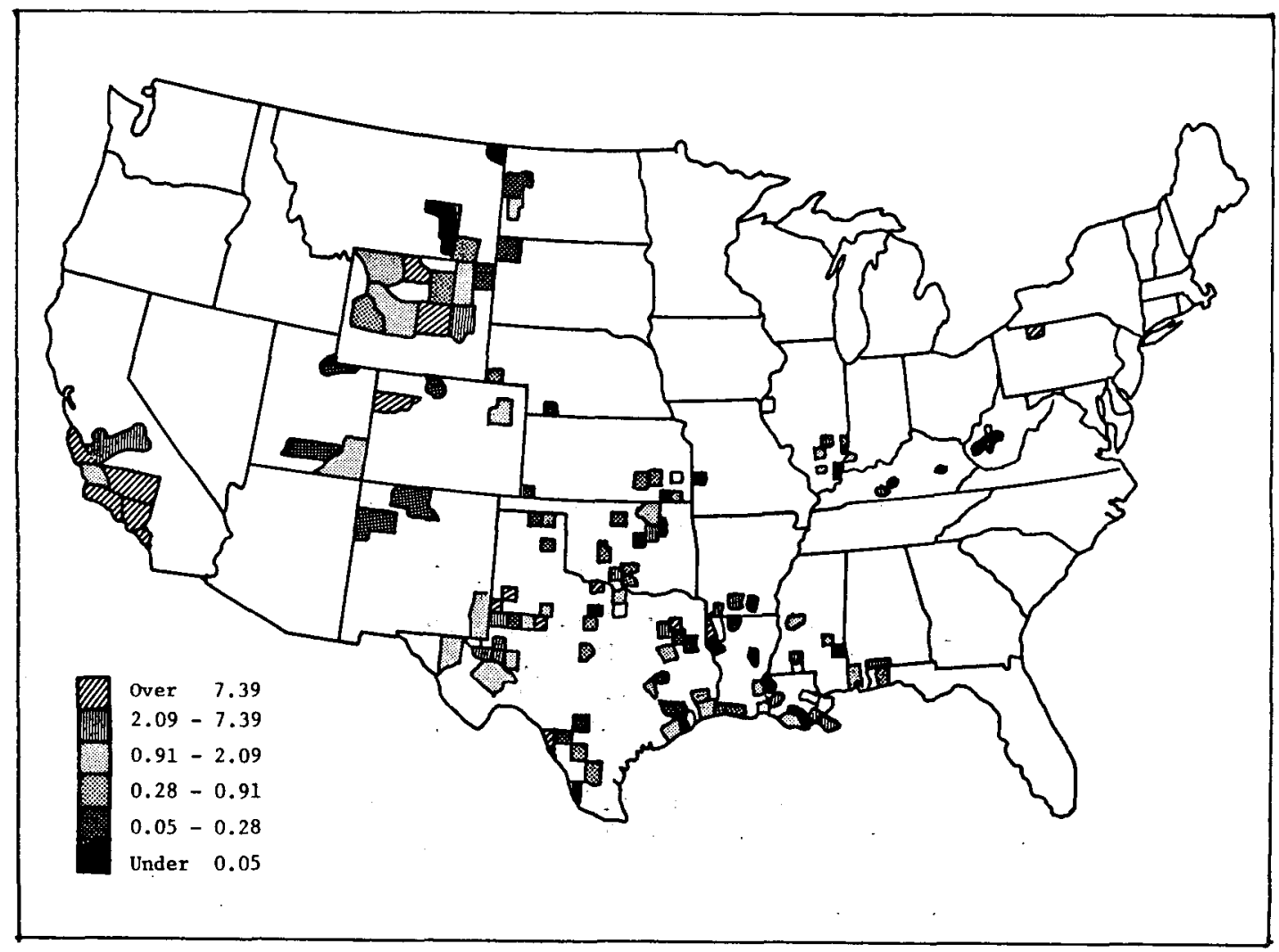

Figure 5.12. Water Requirements in millions of gallons per day for enhanced oil production as projected for the year 2000. 
larger water requirements, in excess of $7.4 \mathrm{Mgd}$, can be found across the U.S, including several counties in California and Texas, Natrona in Wyoming, Rio Blanco in Colorado, McKean in Pennsylvania, Stephens in Oklahoma, Quachita in Arkansas, and Caddo in Louisiana.

The quantity of produced water available for injection depends on the quality of produced water and the type of EOR process. Figure 5.13 shows a hypothetical situation where $75 \%$ of the produced water can be used for EOR processes with the remaining $25 \%$ supplied by freshwater. Steam generation requires cleaner water than other processes. It is likely that less than $75 \%$ of produced water could be used to generate steam. Estimated freshwater requirements for counties where $50 \%$ of the produced water is to be used for generating steam are shown in Figure 5.14 .

In these figures the solid areas show counties where the water requirements will exceed roughly $1.9 \mathrm{Mgd}$. In Figure 5.13 there are 19 counties and in Figure 5.14 there are 20 that exceed these requirements.

\subsubsection{Water Quality}

Water used for injection in oil reservoirs has to be compatible with the chemistry of the formation water, with the chemistry of injected fluids, and with the formation itself. Waters are usually considered compatible if they can be mixed without producing chemical reactions between the different fluids in contact. Precipitation of insoluble compounds is undesirable and may reduce the permeability in the formation. Some fluids may react with the formation clays causing swelling and a reduction of permeability and production from a reservoir.

Suspended and dissolved solids concentration must be very low for steam operation and for micellar-polymer injection. The concentration is not a factor in $\mathrm{CO}_{2}$ and in situ combustion. Microbes, dissolved oxygen, and iron can cause undesired chemical reactions to occur.

The goal of EOR processes is to maintain an (overa11) fluid injection/ production ratio of 1.0 . A decrease in this ratio would indicate fluid encroachment into the reservoir and an increase would indicate escape of injected fluids from the formation.

The quality of produced waters varies enormously from fields such as the Kern River field, where the total dissolved solids (TDS) are <1000 ppm, to Lost Hills, where the TDS content is $30,000 \mathrm{ppm} .17$ The extent to which these waters will be used for reinjection will depend on the EOR process. Table 5.3 shows some general guidelines for injection water quality. Steam injection and micellar-polymer flooding are two technologies that require much higher water quality than $\mathrm{CO}_{2}$ and wet in situ combustion. Steam injection also requires lower $\mathrm{CaCO}_{3}$ concentration in order to reduce scaling of boiler tubes. The micellar-polymer process can use lower quality water for the final drive water than is indicated in Table 5.3.

$\AA$ more complete discussion of water quality requirements for EOR can be found in the literature. 18 


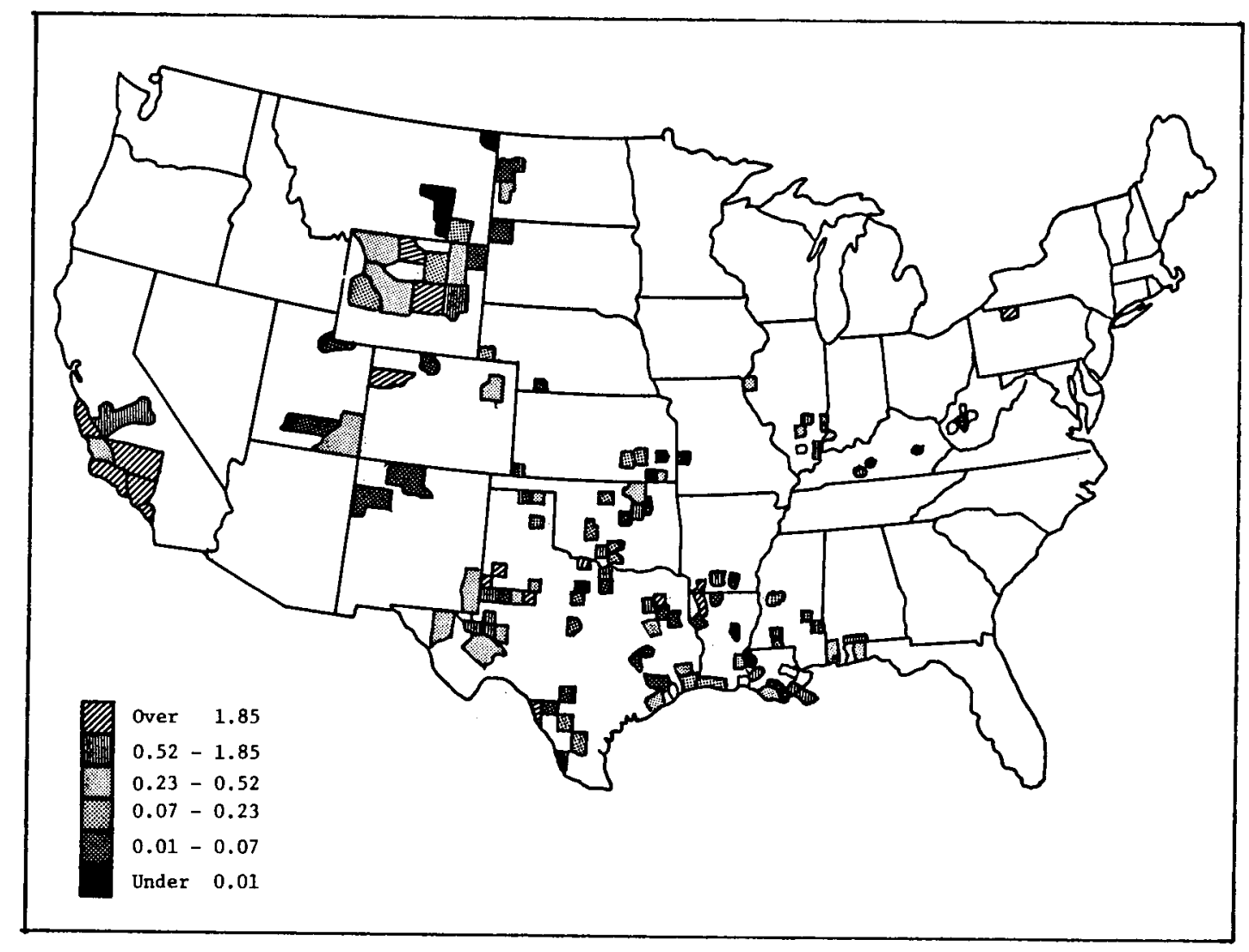

Millions of gallons per day

$\begin{array}{ll}\text { CA } & \text { Kern } \\ \text { CA } & \text { Santa Barbarta } \\ \text { CA } & \text { Los Angeles } \\ \text { TX Yoakum } \\ \text { TX } & \text { Wichita } \\ \text { TX } & \text { Wood } \\ \text { TX } & \text { Scurry } \\ \text { CA } & \text { Monterey } \\ \text { CA } & \text { Orange } \\ \text { CA } & \text { Ventura } \\ \text { CO } & \text { Rio Blanco } \\ \text { PA } & \text { McKean } \\ \text { TX Maverick } \\ \text { TX Hockley } \\ \text { AR } & \text { Quachita } \\ \text { WY } & \text { Ntrama } \\ \text { IA } & \text { Caddo } \\ \text { WY } & \text { Big Horn } \\ \text { IL Lawrence }\end{array}$
34.134
9.103
8.853
5.459
4.526
4.260
4.195
4.039
3.790
3.480
3.354
3.056
2.816
2.771
2.550
3.329
2.323
2.113
1.911

Acre-ft

per year
38258.974
10208.009
9934.288
6118.916
5072.405
4774.759
4701.884
4526.992
4247.313
3900.456
3759.464
3424.756
3156.072
3105.818
2858.671
2610.700
2603. 286
2367.907
2141.944

Figure 5.13. Freshwater requirement in millions of gallons per day in the year 2000, assuming $75 \%$ of produced water is reused. 


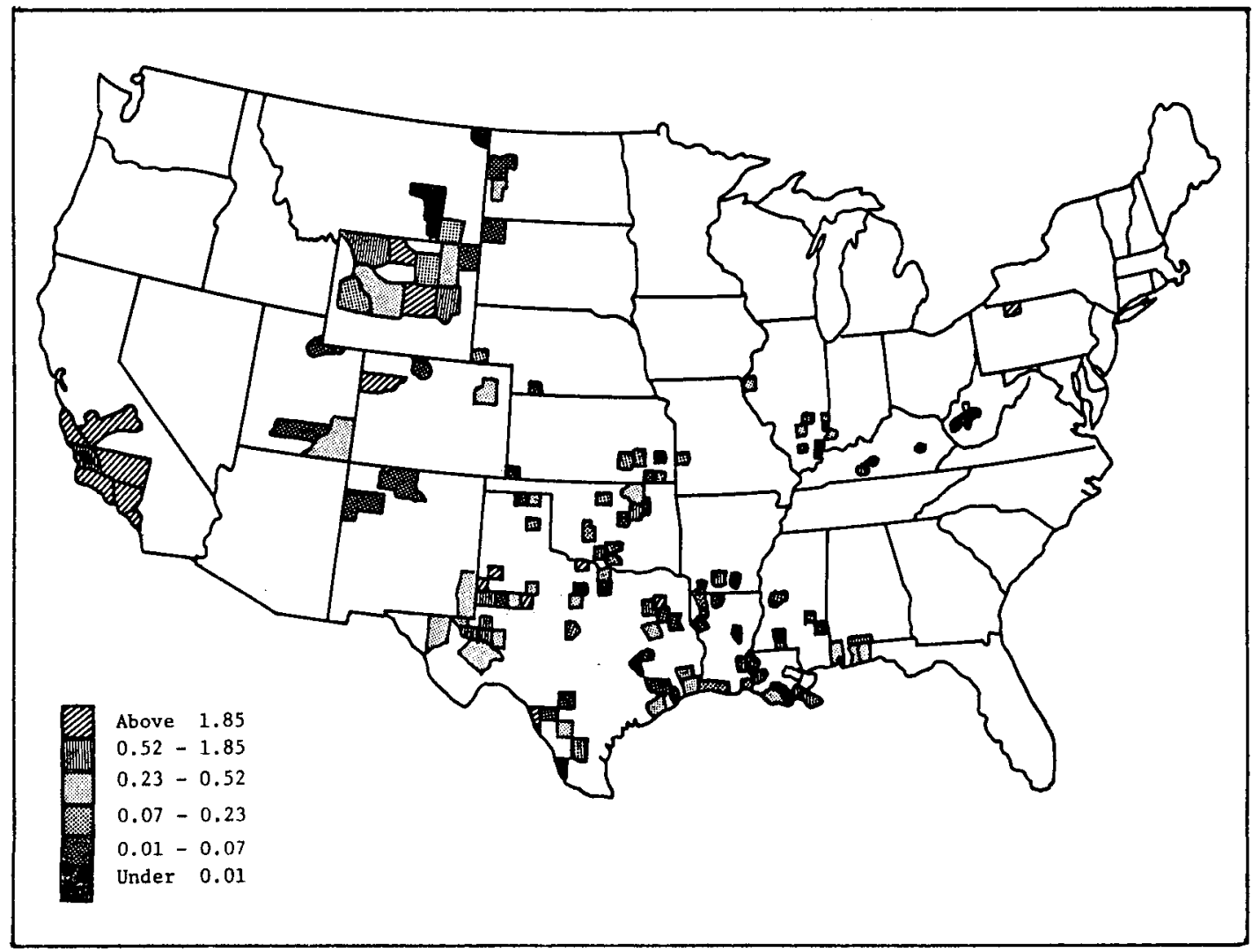

\section{Millions of gallons per day}

$\begin{array}{ll}\text { CA } & \text { Kern } \\ \text { CA } & \text { Santa Barbarta } \\ \text { CA } & \text { Los Angeles } \\ \text { TX Yoakun } \\ \text { TX Wichita } \\ \text { TX Wood } \\ \text { TX Scurry } \\ \text { CA } & \text { Monterey } \\ \text { CA } & \text { Orange } \\ \text { CA } & \text { Ventura } \\ \text { CO } & \text { Rio Blanco } \\ \text { PA } & \text { McKean } \\ \text { TX } & \text { Maverick } \\ \text { TX Hockley } \\ \text { AR Quachita } \\ \text { WY N N troma } \\ \text { LA Caddo } \\ \text { WY Big Horn } \\ \text { IL Lawrence }\end{array}$

$\begin{array}{rr}57.226 & 75350.849 \\ 18.095 & 20281.383 \\ 16.655 & 18667.323 \\ 7.954 & 5914.662 \\ 6.945 & 7787.260 \\ 6.549 & 7451.991 \\ 5.632 & 6312.144 \\ 5.459 & 6116.916 \\ 5.101 & 5717.342 \\ 4.545 . & 5206.571 \\ 4.526 & 5072.405 \\ 4.260 & 4774.789 \\ 4.195 & 4701.664 \\ 3.700 & 4147.368 \\ 3.454 & 3759.484 \\ 3.056 & 3424.756 \\ 2.771 & 3105.616 \\ 2.427 & 2720.269 \\ 1.911 & 2141.944\end{array}$

Figure 5.14. Freshwater requirement assuming $50 \%$ of produced water is reused for steam recovery and $75 \%$ of produced water is reused for other EOR processes. 
Table 5.3

General Guidelines for Injection Water Quality

\begin{tabular}{|c|c|c|c|c|c|}
\hline & $\begin{array}{c}\text { Total } \\
\text { Dissolved } \\
\text { Solids } \\
\end{array}$ & $\begin{array}{c}\text { Total } \\
\text { Suspended } \\
\text { Solids }\end{array}$ & $\begin{array}{c}\text { Total } \\
\text { Hardness } \\
\left(\text { as } \mathrm{CACO}_{3}\right)\end{array}$ & $\begin{array}{c}\text { Dissolved } \\
\text { Gases } \\
\left(\mathrm{CO}_{2}, \mathrm{H}_{2} \mathrm{~S},\right. \\
\left.\mathrm{O}_{2}\right)\end{array}$ & $\begin{array}{l}\text { Microbio- } \\
\text { logical }\end{array}$ \\
\hline $\begin{array}{l}\text { Steam } \\
\text { injection }\end{array}$ & $\begin{array}{l}\text { Less than } \\
5000 \mathrm{mg} / 1\end{array}$ & $\begin{array}{l}\text { Less than } \\
1.0 \mathrm{mg} / 1\end{array}$ & $\begin{array}{l}\text { Less than } \\
1.0 \mathrm{mg} / 1\end{array}$ & $\begin{array}{l}\text { Less than } \\
1.0 \mathrm{mg} / 1\end{array}$ & $0 \mathrm{mg} / \mathrm{l}$ \\
\hline $\begin{array}{l}\text { In situ } \\
\text { combustion }\end{array}$ & $\begin{array}{l}\text { Up to } \\
100,000 \\
\mathrm{mg} / 1\end{array}$ & $\begin{array}{l}\text { Less than } \\
1.0 \mathrm{mg} / 1\end{array}$ & $\begin{array}{l}\text { Less than } \\
500 \mathrm{mg} / 1\end{array}$ & $\begin{array}{l}\text { Less than } \\
1.0 \mathrm{mg} / 1\end{array}$ & $0 \mathrm{mg} / \mathrm{l}$ \\
\hline $\mathrm{CO}_{2}$ & $\begin{array}{l}\text { Up to } \\
100,000 \\
\mathrm{mg} / 1\end{array}$ & $\begin{array}{l}\text { Less than } \\
1.0 \mathrm{mg} / 1\end{array}$ & $\begin{array}{l}\text { Less than } \\
500 \mathrm{mg} / 1\end{array}$ & $\begin{array}{l}\text { Less than } \\
1.0 \mathrm{mg} / 1\end{array}$ & $0 \mathrm{mg} / 1$ \\
\hline $\begin{array}{l}\text { Micellar- } \\
\text { polymer } \\
\text { flooding }\end{array}$ & $\begin{array}{l}\text { Less than } \\
5000 \mathrm{mg} / 1\end{array}$ & $\begin{array}{l}\text { Less than } \\
1.0 \mathrm{mg} / 1\end{array}$ & $\begin{array}{l}\text { Less than } \\
500 \mathrm{mg} / 1\end{array}$ & $\begin{array}{l}\text { Less than } \\
1.0 \mathrm{mg} / 1\end{array}$ & $0 \mathrm{mg} / \mathrm{l}$ \\
\hline
\end{tabular}

California Fields. The average requirement is based on a 40-year average production level for each field. For our projected average oil production levels, Kern County fields will require by far the largest amount of water, rough1y $34 \mathrm{Mgd}$ of freshwater each year even if $75 \%$ of the water requirements are met by produced water. Santa Barbara County fields will require another $8.9 \mathrm{Mgd}$ of freshwater under the same conditions. Water requirements for other counties in the area, such as Los Angeles, Monterey, Orange, and Ventura, are projected at $8.8,4.0,3.7$, and $3.5 \mathrm{Mgd}$ by the year 2000 .

It is assumed that $25 \%$ of the water demand would be met by freshwater. This figure may be lower--perhaps as low as $10 \%-$-depending on the quality of produced water. The range of freshwater requirements is fairly wide. To put these projected figures into perspective, data obtained from the California Department of Water Resources as to the expected freshwater needs of three oil companies for tertiary oil production show a variation from complete recycling of produced water to $100 \%$ freshwater use. In the Kern River field, the ratio of freshwater to produced water is currently less than $0.5 \%$ but is expected to increase to $8 \%$ by the year 2000. In the Cat Canyon field freshwater accounts for $100 \%$ of the current water use. This proportion is expected to decline to $10 \%$ of the produced water by the time the field is fully developed. Another example is the Midway field in Kern County where freshwater use is $400 \%$ of the produced water. This ratio is expected to decline to $52 \%$ by the year 2000 .

The sources of water are equally varied. Produced water from the same formation will be the first choice. Surface water, where avallable, will be 
the second choice. Groundwater is not available at every field site. Fields on the west side of Kern County have no groundwater reservoirs to rely on. Fields such as Midway and Sunset, with freshwater requirements on the order of $6.5 \mathrm{Mgd}$, will have to rely on the California Aqueduct. 19 Although the total amount is small when compared with the expected capacity of the aqueduct to carry $1200 \mathrm{Mgd}$ to the surrounding Tulare Basin, 20 it is not clear if freshwater requirements for such fields were considered in estimating the aqueduct capacity. If freshwater requirements of all the fields in the Tulare Basin (Kern County) are totaled for the major oil producers, they amount to $9.8 \mathrm{Mgd}$ in the year 2000. These major producers accounted for $1.356 \times 10^{5} \mathrm{bbl}$ of EOR oil production out of a total of $2.464 \times 10^{5} \mathrm{bbl}$, or roughly $55 \%$ of the total production in 1978. Using this same fraction, the freshwater requirement for all EOR production is estimated to be $18 \mathrm{Mgd}$, less than the average of $34 \mathrm{Mgd}$ estimated earlier. If, on the other hand, the major producers represent a smaller share of oil production in the year 2000 , then the 18-Mgd estimate may actually be low.

If, as most oil companies expect, California EOR production peaks circa 1990, with many of the fields peaking at the same time, freshwater requirements could exceed the above estimates considerably because the estimates were based on averaged production over 40 years.

Part of the freshwater requirements for these fields may be met by groundwater sources because aqueduct supplies are used primarily for agriculture. Groundwater overdrafts, already a serious problem in the Tulare Lake and Kern County Basins where they are 38 and $535 \mathrm{Mgd}$ respectively, are expected to continue in the future in both areas. Major problems of overdraft relate to increased salinity and increased pumping costs. 21

U.S. (except California). Large freshwater requirements are found in 13 counties outside California (Figure 5.13), where water requirements range from $5.5 \mathrm{Mgd}$ in Yoakum County, Texas, to $1.9 \mathrm{Mgd}$ in Lawrence, Illinois. Table 5.4 shows the water consumption and the groundwater overdraft in each Water Resources Council Subregion. 22 The subregions are shown in Figure 5.15 , and the groundwater overdraft is illustrated in Figure 5.16. Except in parts of the South Atlantic, Gulf Region, Ohio Region, and the Upper Colorado, groundwater overdraft is common across all the EOR oil-producing subregions. Groundwater will not be plentiful by 2000; on the contrary, groundwater quality is so poor that further overdrafting cannot continue in the year 2000 .

Water requirements for oil production in Texas ranged from 268 to 357 Mgd during the late $1960 \mathrm{~s}$ and throughout the $1970 \mathrm{~s}$. Freshwater requirements for al1 oil production amounted to roughly $89 \mathrm{Mgd}$ of this amount.23 Freshwater use has continued to decline during the last ten years. The availability of freshwater and the need to dispose of increasing volumes of brackish and saline water have contributed to this trend. It is assumed that $25 \%$ of the water injected in Texas will be fresh water.

Stephens County, Oklahoma, and Wichita County, Texas, are both part of subregion 1106, where groundwater overdraft is $1300 \mathrm{Mgd}$. Incidentally, groundwater quality is relatively poor because of high salinity levels in this area. Caddo County, Louisiana, is in region 1107 with a groundwater 


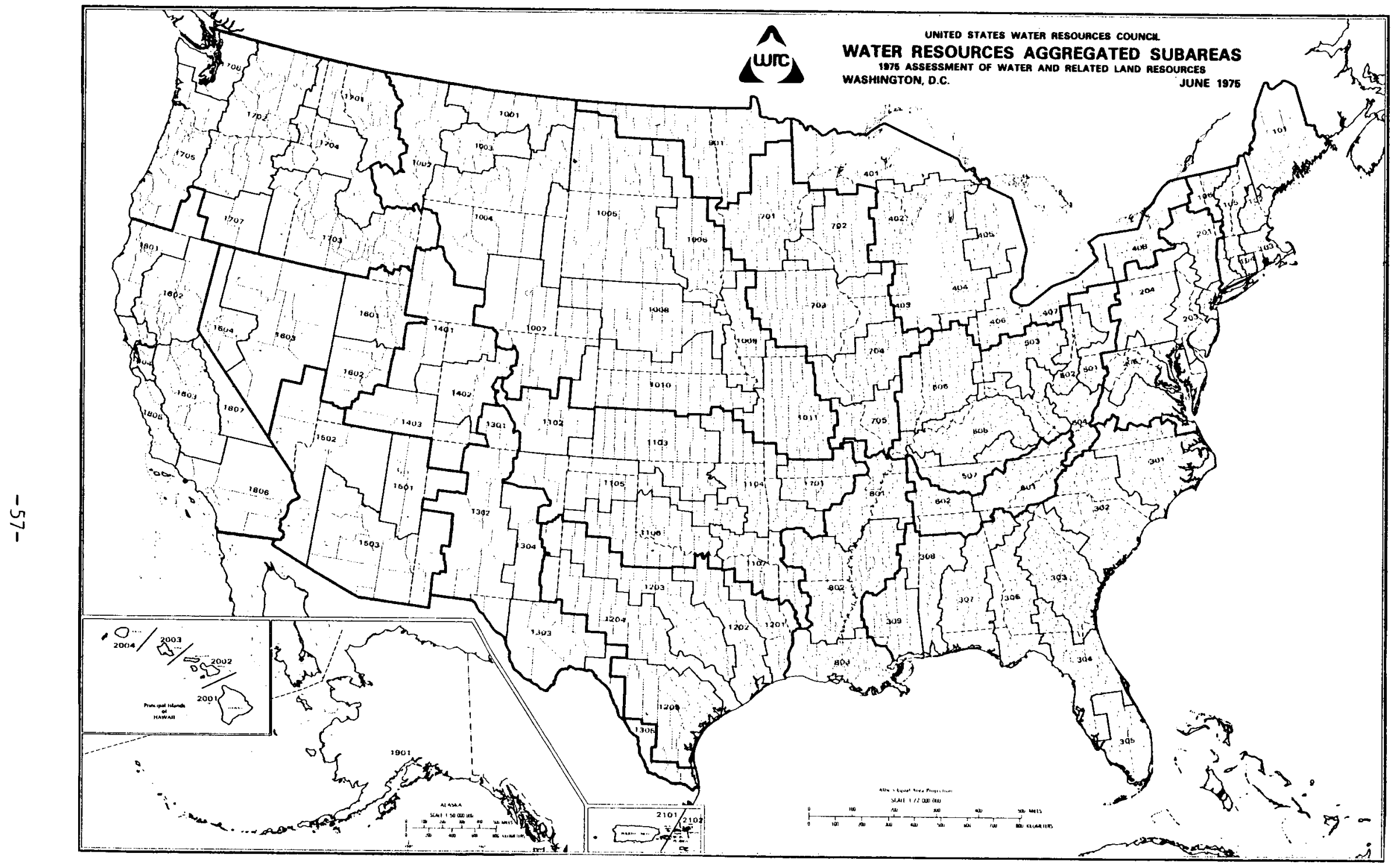

Figure 5.15. Assessment subareas (county approximations of assessment subregions).

Source: Reference 23. 


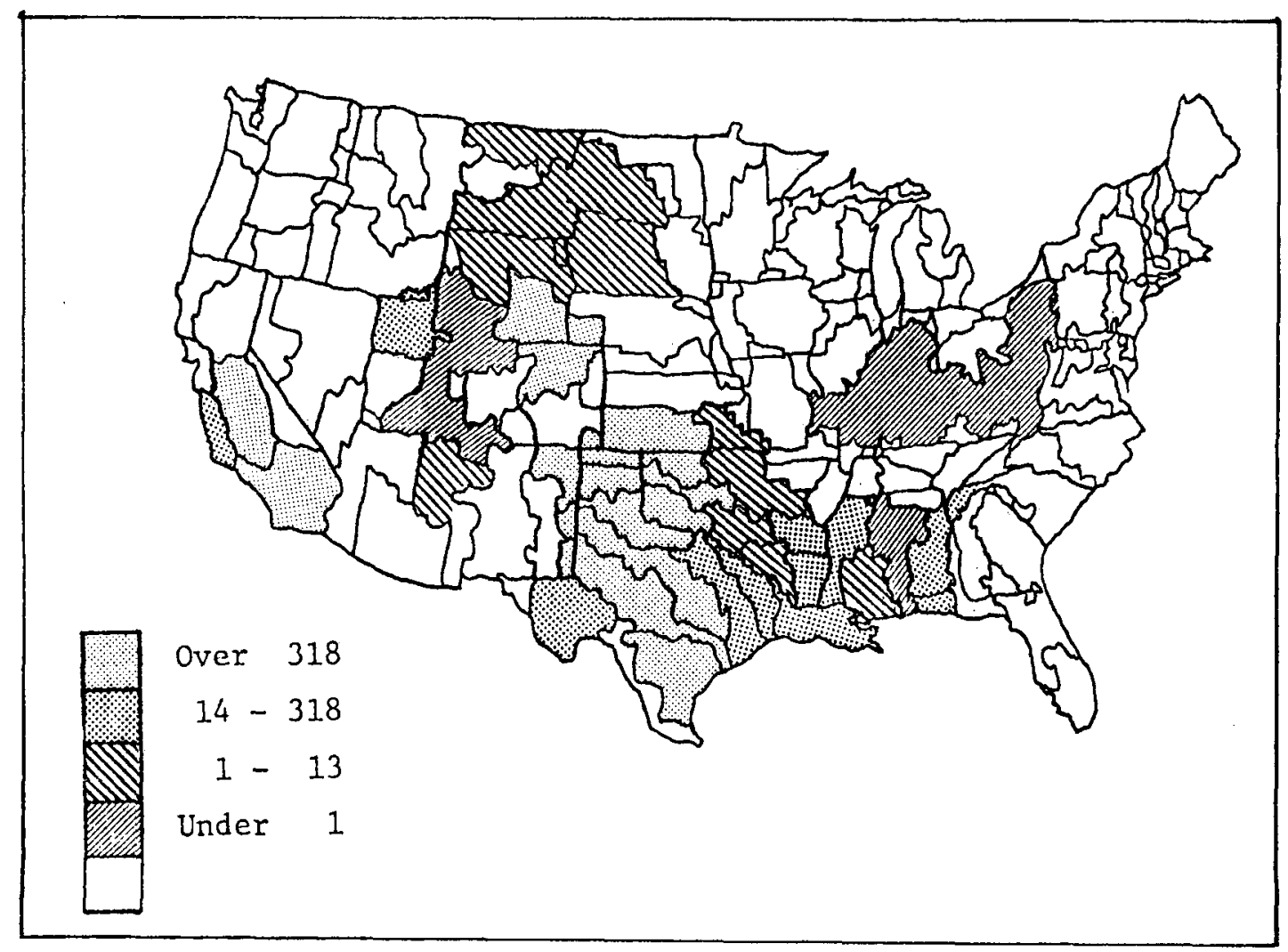

Figure 5.16. Groundwater overdraft within each subregion in millions of gallons per day in the year 1975 .

overdraft of $2 \mathrm{Mgd}$ compared to a consumption of $179 \mathrm{Mgd}$. Groundwater quality problems have been reported in this area.

Osage, Tulsa, Creek, Lincoln, and Garfield are other Oklahoma counties where EOR production will require freshwater. Throughout this portion of region 11 , severe water problems have been reported, relating to groundwater quantity, groundwater quality, and conflicting water use. The quantity of available water is inadequate for many needs, and cities and industries may have to change their patterns of water use. Large irrigation requirements in this region often exacerbate the situation by creating groundwater depletions.

Yoakum and Wood Counties in West Texas are EOR counties in which oil fields may require $9.7 \mathrm{Mgd}$. Yoakum County is at the boundary of regions 1204 and 1203. Both these regions of the Texas High Plains underlain by the Ogallala and Edward - Trinity Aquifers have large groundwater overdrafts of 1157 and $3767 \mathrm{Mgd}$, respectively. Because of the overdrafts, the water table has been dropping rapidly in the High Plains. 24 The deeper water is more brackish, thus precluding its use for agriculture, municipal needs, and ofl production. Water supply may become critical in this region, even though recycling of water for $\mathrm{CO}_{2}$ projects is extensive. 
Table 5.4

Water Consumption and Groundwater Overdraft

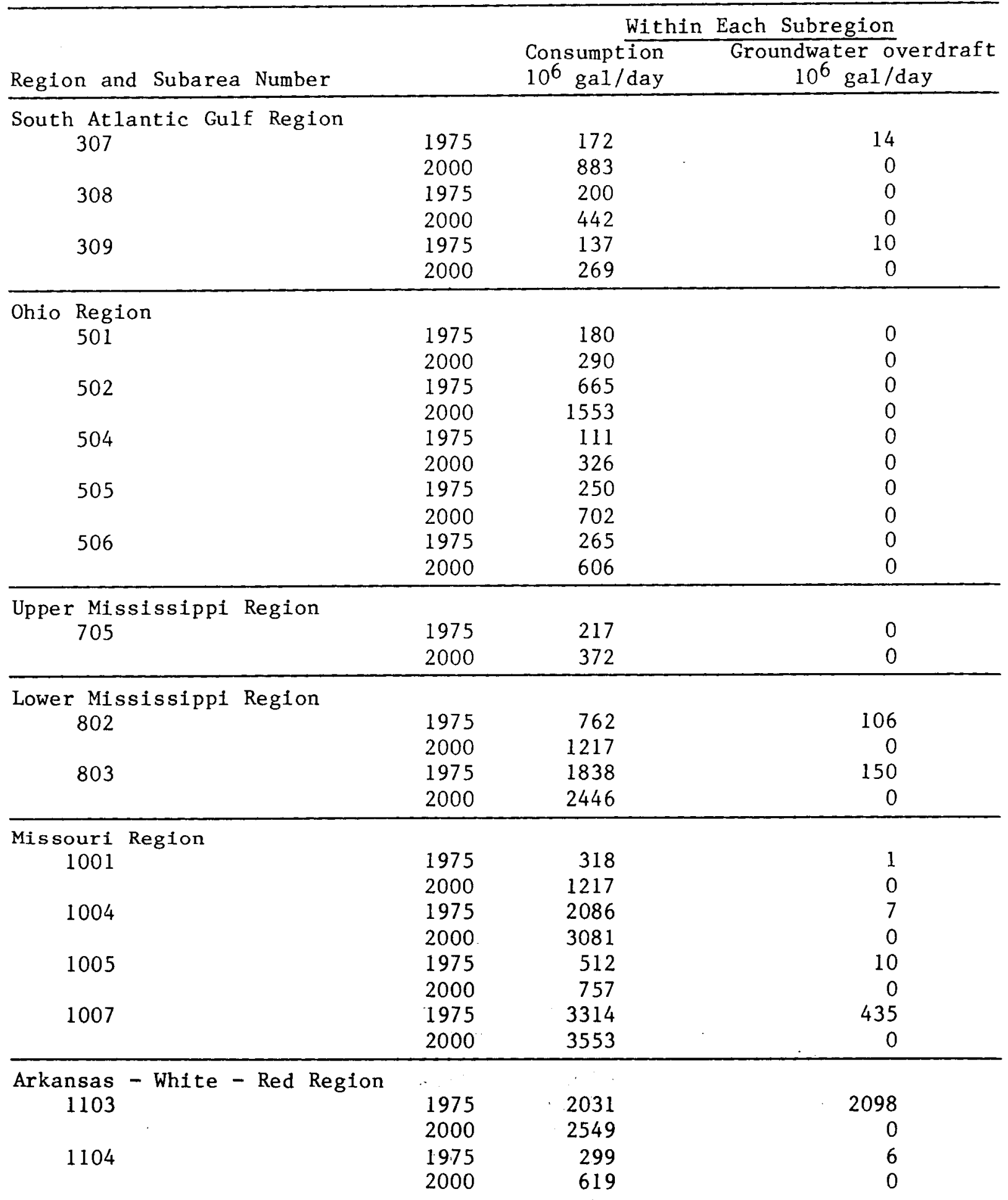


Table 5.4 (continued)

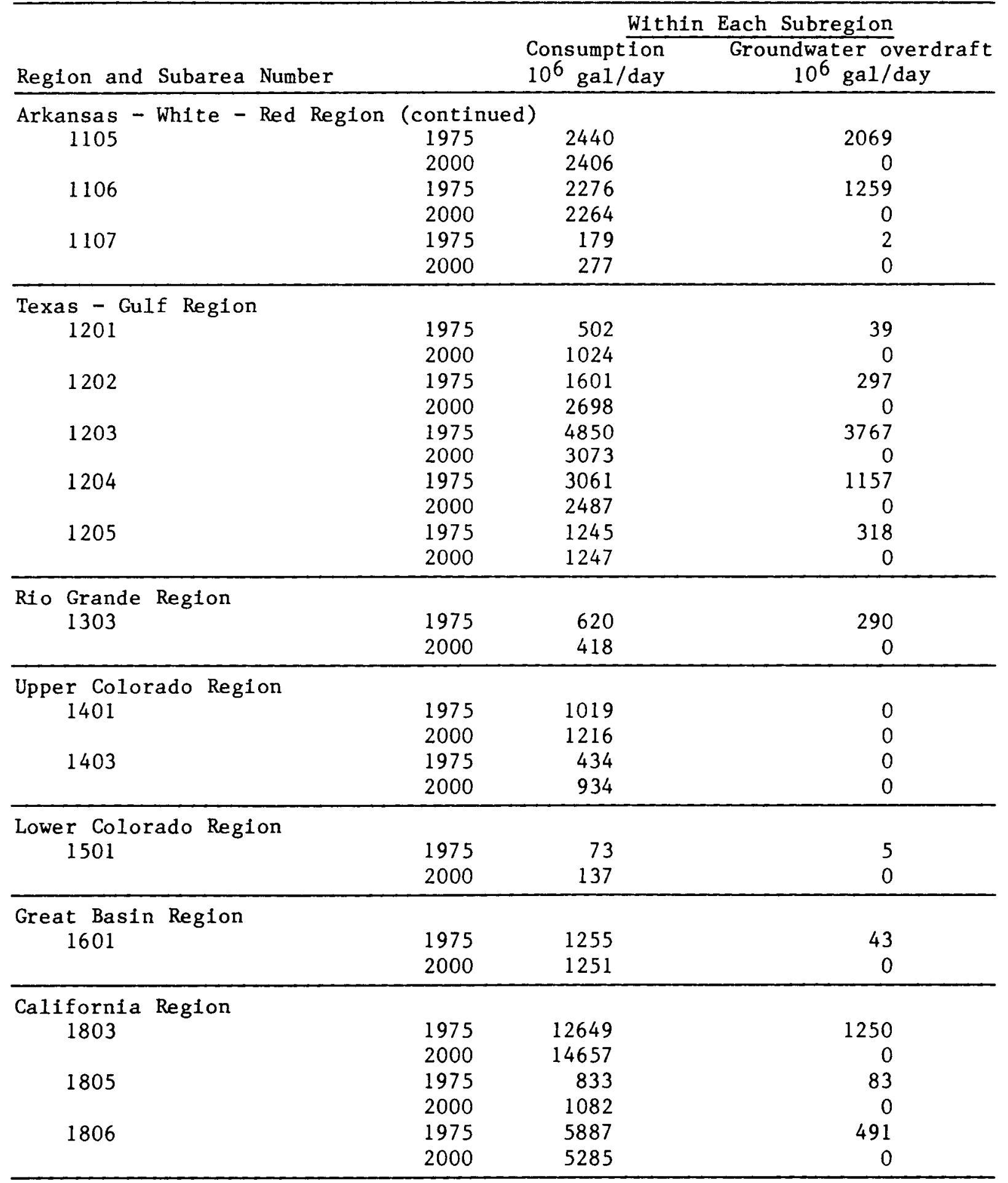

Source: Reference 22. 
Ward County is also in the High Plains area at the boundary of regions 1204 and 1303. Region 1303 also includes Maverick County, which has an overdraft of $290 \mathrm{Mgd}$. Both groundwater quantity and quality problems are reported in this Trans-Pecos region of Texas. 25 The existing supply is completely appropriated by current demands, and no surplus water is available. EOR water requirements in Ward, Culbertson, Ector, Upton, Pecos, and Loving Counties will amount to $4.9 \mathrm{Mgd}$, including water recycled for $\mathrm{CO}_{2}$ projects, thus adding to the burden placed on groundwater.

Quachita County, Arkansas, in region 802 has an overdraft of $106 \mathrm{Mgd}$, but no problems are reported in this area. Natrona and Converse Counties, Wyoming, are part of region 1007; parts of both counties are in the Middle North Platte River Basin. Groundwater quality and major water use conflicts have been reported, but groundwater overdraft is minimal compared with consumption. EOR freshwater requirements in these two counties are estimated at $3.1 \mathrm{Mgd}$. Extensive EOR development is projected for region 1004 which includes Big Horn County, Wyoming. Although no major groundwater quantity problems are identified for this subregion, water use conflicts and water quality degradation due to brine contamination are both possible.

Conclusion. Severe groundwater problems may or may not constrain the development of fields for increased EOR production because of difficulties in acquiring water, delay of projects, and pressure on developers to use more produced and recycled water. Each development by itself requires a unique set of decisions, partly institutional and partly economic. If the price of water is relatively low, the developer will probably purchase it as long as it is cheaper than treating produced water.

Kern County, California, is an interesting example of an area with all the attendant problems. Groundwater overdraft is very large in the basin, where all the water is already allocated. A new oil producer faces the following choices (not necessarily in this order of priority): (1) use produced water directly, (2) use treated produced water, (3) contact the local water agency for additional water, (4) tap into groundwater reservoirs, (5) buy land in anticipation of expansion, and (6) buy water from other users. If freshwater is not readily available, and this may be the case in Kern County, 26 producers will resort to the last two options. Many producers have already resorted to option (5). Both options (5) and (6) require additional initial capital to start a project. Large producers, or those already having access to water, will be less affected, but in regions where water is in short supply, small EOR operators may be adversely affected and even squeezed out of the market.

In many locations, however, the rights to groundwater may not be clear. Multipurpose use of groundwater from the same reservoir for agriculture, industry, and ofl production can create legal problems when the freshwater supply is shrinking. In Gaines County, Texas, for example, the rights to groundwater are undergoing legal challenge. 27 The outcome may help clarify such rights nationally. Similar problems may be expected in other areas as EOR production expands and conflicts with rights of other users to the same groundwater. 


\subsubsection{Groundwater Contamination}

Numerous reports and studies have demonstrated that groundwater contamination is a widespread problem affecting every region of the country. Contamination may result from petroleum production, injection wells, surface impoundments, agriculture, landfills, leaks and spills, septic tanks, and mining activities. An EPA report 28 to Congress identified the disposal of industrial wastes at industrial impoundments and solid waste disposal sites as the most important source of nationwide contamination. In many regions, petroleum activities are the primary cause of contamination, but such sources are located farther from population centers than industrial sources, and are therefore harder to detect.

Table 5.5 shows the regional ranking of contamination problems by source. Petroleum-related problems predominate in the South Central, Southwest, and Northwest regions. In other areas, industrial waste and domestic sewage disposal have the largest impacts on groundwater owing to substantial manufacturing activity and high population densities.

In the dry areas (e.g., the South Central, the Southwest, and parts of the Northwest regions) evaporation exceeds precipitation, and groundwater problems are related to overdrafts and to the buildup of total dissolved solids. In wetter regions, landfill leaching is a major problem.

Groundwater impacts related to petroleum development are not well documented. In some areas the extent of contamination has been quantified, but data are not generally available. Several different activities have caused contamination in the South Central and Southwest regions. In Texas 23,000 cases of ground- and surface-water contamination have been reported. Formerly a major cause of contamination, the use of unlined pits to dispose of brines is now banned in many producing states. An EPA report 29 estimates that oil and gas and mining impoundments may have contaminated $0.1 \%$ of the nation's usable aquifer area.

Brine is now disposed of by underground injection into deep saline formations and occasionally into lined pits. Underground injection will be regulated by the EPA's Underground Injection Control (UIC) Program. The Safe Drinking Water Act (1974) established the UIC program to prevent underground injection of wastes that endanger drinking water sources. States may assume primary enforcement responsibility for operating effective programs. One such state, California, and its contamination data for brine injection wells are discussed later in this report.

There are an estimated $5 \times 10^{5}$ operational injection wells nationwide, of which $1.4 \times 10^{5}$ are wells for disposal of fluids brought to the surface in connection with oil and gas production or for injection of fluids to increase oil and gas recovery (Class II wells). It is also estimated that $1.2 \times 10^{6}$ abandoned wells are located near the review areas for underground injection wells. Often wells have been improperly abandoned with no trace on the surface. Brines from EOR oil operations may leak from these improperly abandoned wells and contaminate aquifers. 
Table 5.5

Relative Importance of Different Sources of Groundwater Contamination

\begin{tabular}{|c|c|c|c|c|c|c|}
\hline & National & $\begin{array}{c}\text { North- } \\
\text { east }\end{array}$ & $\begin{array}{c}\text { South- } \\
\text { east }\end{array}$ & $\begin{array}{l}\text { South- } \\
\text { Central }\end{array}$ & $\begin{array}{c}\text { South- } \\
\text { west }\end{array}$ & $\begin{array}{c}\text { North- } \\
\text { west }\end{array}$ \\
\hline $\begin{array}{l}\text { Industrial } \\
\text { impoundments } \\
\text { Land disposal } \\
\text { sites }\end{array}$ & $a$ & $a$ & a & c & c & $\mathrm{a}$ \\
\hline Septic tanks & a & a & a & $\mathrm{b}$ & $\mathrm{b}$ & $\mathrm{b}$ \\
\hline and cesspools & a & a & a & $c$ & c & a \\
\hline $\begin{array}{l}\text { Municipal waste } \\
\text { water }\end{array}$ & $\mathrm{b}$ & $\mathrm{b}$ & $c$ & $\mathrm{~b}$ & c & $\mathrm{a}$ \\
\hline $\begin{array}{l}\text { exploration } \\
\text { Mining }\end{array}$ & $\begin{array}{l}\mathrm{b} \\
\mathrm{b}\end{array}$ & $\begin{array}{l}\mathrm{c} \\
\mathrm{b}\end{array}$ & $\begin{array}{l}\mathrm{c} \\
\mathrm{b}\end{array}$ & $\begin{array}{l}\mathrm{a} \\
\mathrm{b}\end{array}$ & $\begin{array}{l}\mathrm{a} \\
\mathrm{c}\end{array}$ & $\begin{array}{l}\mathrm{a} \\
\mathrm{b}\end{array}$ \\
\hline $\begin{array}{l}\text { Other important } \\
\text { contamina- } \\
\text { tion sources, } \\
\text { including } \\
\text { nondisposal } \\
\text { sources }\end{array}$ & $\begin{array}{l}\text { Spills; } \\
\text { leaks; } \\
\text { road sa1t; } \\
\text { storage } \\
\text { tanks }\end{array}$ & $\begin{array}{l}\text { Spills; } \\
\text { leaks; } \\
\text { storage } \\
\text { tanks; } \\
\text { agricul- } \\
\text { tural } \\
\text { activi- } \\
\text { ties }\end{array}$ & $\begin{array}{l}\text { Natural } \\
\text { leaching; } \\
\text { irriga- } \\
\text { tion re- } \\
\text { turn; } \\
\text { aban- } \\
\text { doned } \\
\text { wells }\end{array}$ & $\begin{array}{l}\text { Natural } \\
\text { leach- } \\
\text { ing; irri- } \\
\text { gation re- } \\
\text { turn; sea- } \\
\text { water en- } \\
\text { croach- } \\
\text { ment }\end{array}$ & $\begin{array}{l}\text { Irriga- } \\
\text { tion re- } \\
\text { turn; } \\
\text { aban- } \\
\text { doned } \\
\text { wells }\end{array}$ & \\
\hline \multicolumn{7}{|c|}{$\begin{array}{l}\text { Note: Relative importance ratings (a-high; b-moderate; c-low) are based on } \\
\text { the typical health hazard of the contaminants, the typical size of the } \\
\text { area affected, and the distribution of the waste disposal practice } \\
\text { across the U.S. A waste disposal practice may be a serious problem in } \\
\text { certain areas, but if the number of such areas is relatively small, } \\
\text { then the practice would not be given a high national rating. A very } \\
\text { widespread practice which does not create serious problems even where } \\
\text { sources of contamination are concentrated would also be given a low } \\
\text { rating with regard to national importance. } \\
\text { Source: Reference 29. }\end{array}$} \\
\hline
\end{tabular}

There are two major underground sources of groundwater contamination common to primary, secondary, and tertiary production of oil: oil from oil wells and brine from injection or disposal wells. In tertiary recovery the chemicals used for oil recovery are an additional hazard. Surface spills of these contaminants and leakage from storage tanks and ponds and from pipelines are other major sources of contamination.

Figure 5.17 shows the various ways by which groundwater contamination can occur. There are three pathways through which undesired fluids might leak into groundwater aquifers. One pathway occurs in a surface spill (not shown); either actual spills or leaky equipment may cause soil and water contamination. A second pathway occurs in the well casing, usually the result of damage caused by corrosion of the casing, with fluid reaching the aquifer by direct contact. The third pathway is available through in fissures, fractures, and semfpermeable layers. Brine or other fluids 


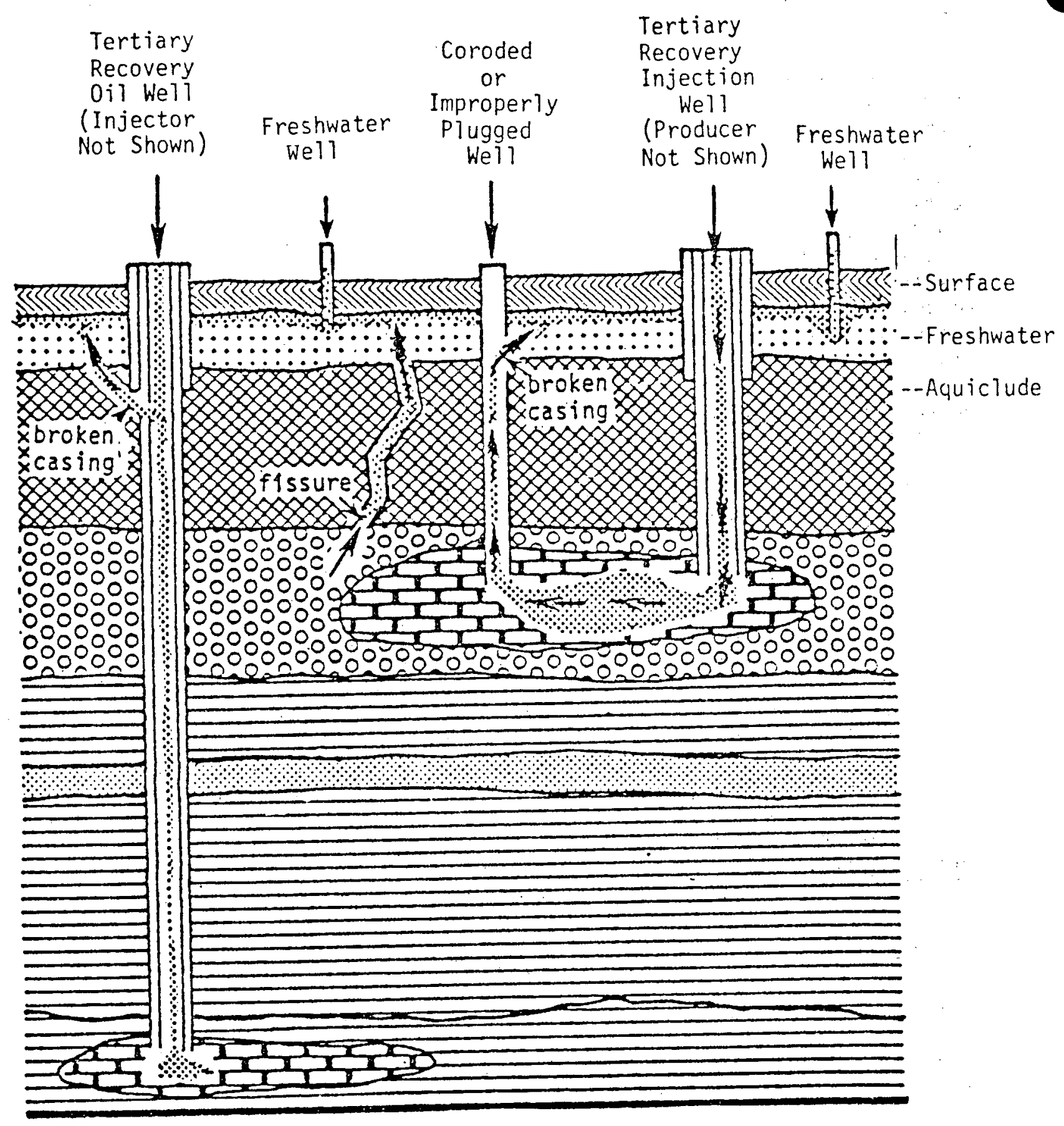

\section{Contaminant}

Figure 5.17. The contamination of freshwater through bypass of the natural filter system (ref. 1). 
injected in the aquifer or into the reservoir under pressure can migrate through this pathway to the potable water aquifer.

Oil Contamination. Oil infiltrating into the ground tends to move downward because of gravitational forces, coating the grains of the soil until a residual saturation is established. Excess oil then flows downward until it reaches the water table. Capillary forces and the water table gradient govern the horizontal flow of this oil. Oil and water have different densities and are relatively immiscible. As a result, most of the oil forms a film on top of the water table before it begins to flow, because of capillary action at the water table (Figure 5.18). Because oil is sparingly soluble in water, hydrocarbons migrate from the oil layer into the water layer, resulting in significant contamination of waters with organic material. Although concentrations are low (e.g., $\mathrm{ppb}$ to $\mathrm{ppm}$ ), they exceed water quality standards and criteria for many key constituents.

The likelihood of an oil spill reaching groundwater depends on several factors. The oil spill must first reach the groundwater table. This possibility depends on (1) the residual oil saturation (Figure 5.19); (2) the soil characteristics, particularly the porosity and permeability; ( 3 ) the

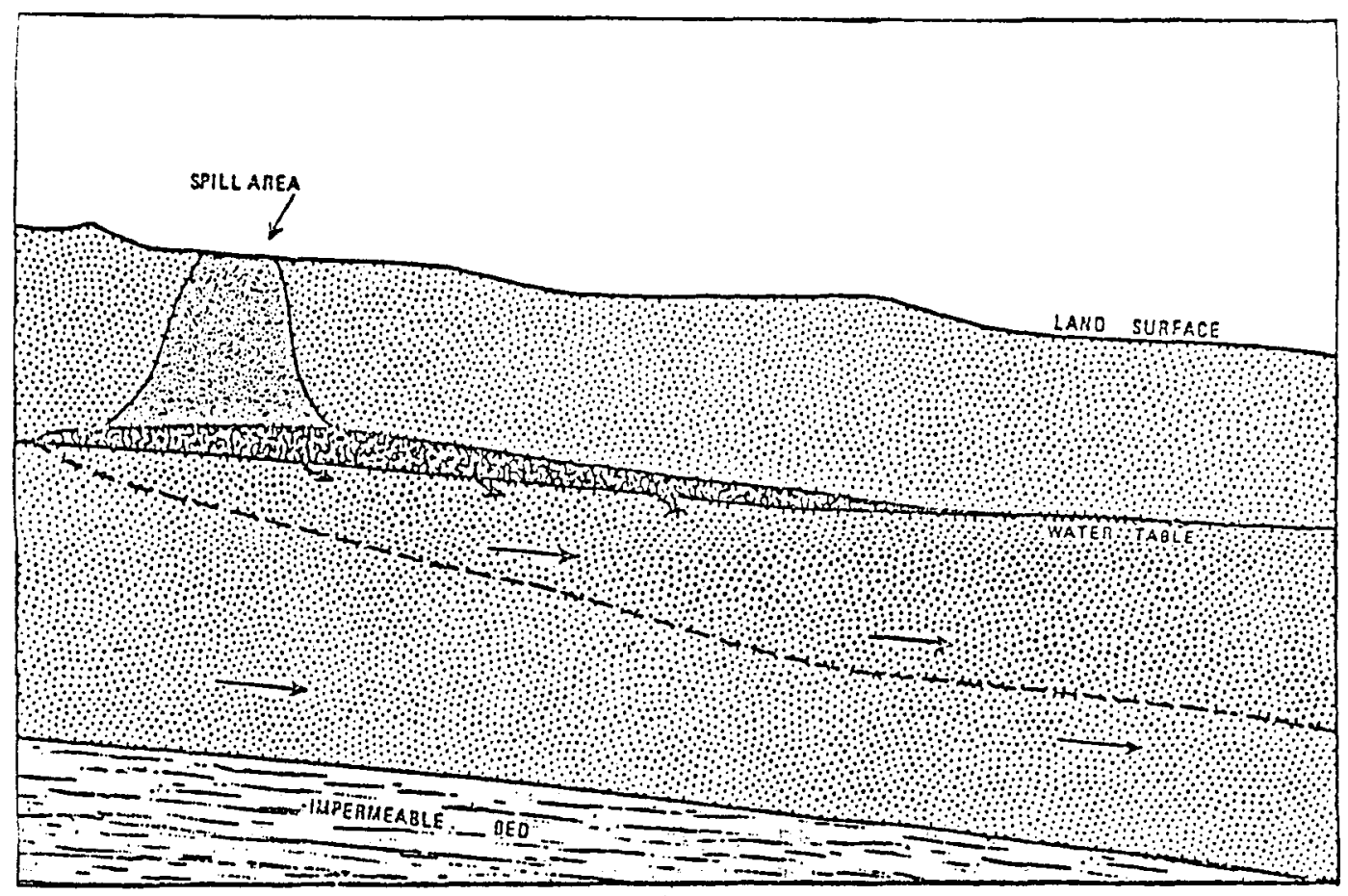

Groundwater contaminated by soluble components

Cir Floating on water table

Residual saturation

Figure 5.18. The migration of petroleum products in sol1 and groundwater (ref. 30 ). 


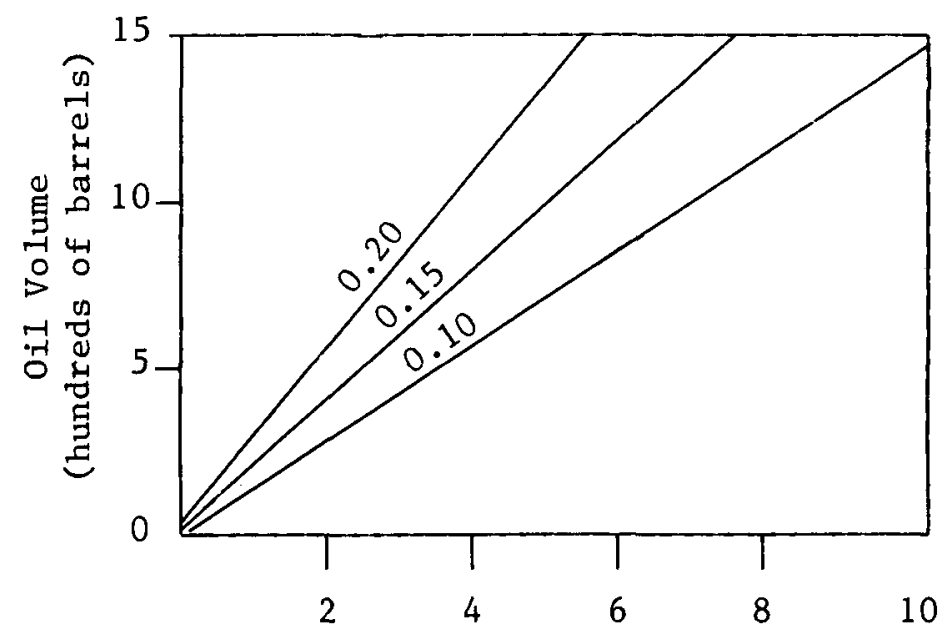

Volume of Contaminated Soil

(thousands of cubic yards)

Figure 5.19 Residual ofl saturation (ref. 30 ).

presence of air and water, which tends to reduce the migration velocity of oil; and (4) the depth to the water table. Once the oil reaches an aquifer, it tends to flatten and spread out. Down gradient of the spill location, the chances of the ofl reaching a user are relatively high.

If an aqueous phase and oxygen are present, most oils will degrade biologically. However, case histories indicate that in high concentrations, oll biodegradation is a slow process.30,32 0i1-contaminated areas can render groundwater unusable for dozens of years. Figure 5.20 shows the spread of oil saturation over time for one soil type.

Two methods exist for cleaning up groundwater contaminated by oil spills. One is to create a local depression in the water table, forcing water to flow towards the depression. Oil floating on the water table within the depression can be pumped from groundwater surface for disposal. The second method, applicable only for shallow water tables, is the construction of a ditch intersecting the water table across the front of a migrating body of o11.

Brine Contamination. The major difference between oil and brine contamination is that brines are completely miscible with water, whereas ofl is not. Brines mix with water and are carried towards the user far more easily than oil. Brine contamination and the release of inorganic and organic compounds and trace metals can be far more serious than ofl contamination because of the amounts of brine involved. Although numbers vary between 1 to 20 barrels of brine for disposal per barrel of tertiary oil produced, depending on EOR technique and on individual projects, a rough estimate would be 4 barrels of brine (requiring disposal) for every barrel of tertiary oil. Hence the "average" brine production for the year $2000 \mathrm{might}$ be derived from Figure 5.11, simply by multiplying the numbers for oil production by 4. In tertiary recovery, brines are injected under pressures 


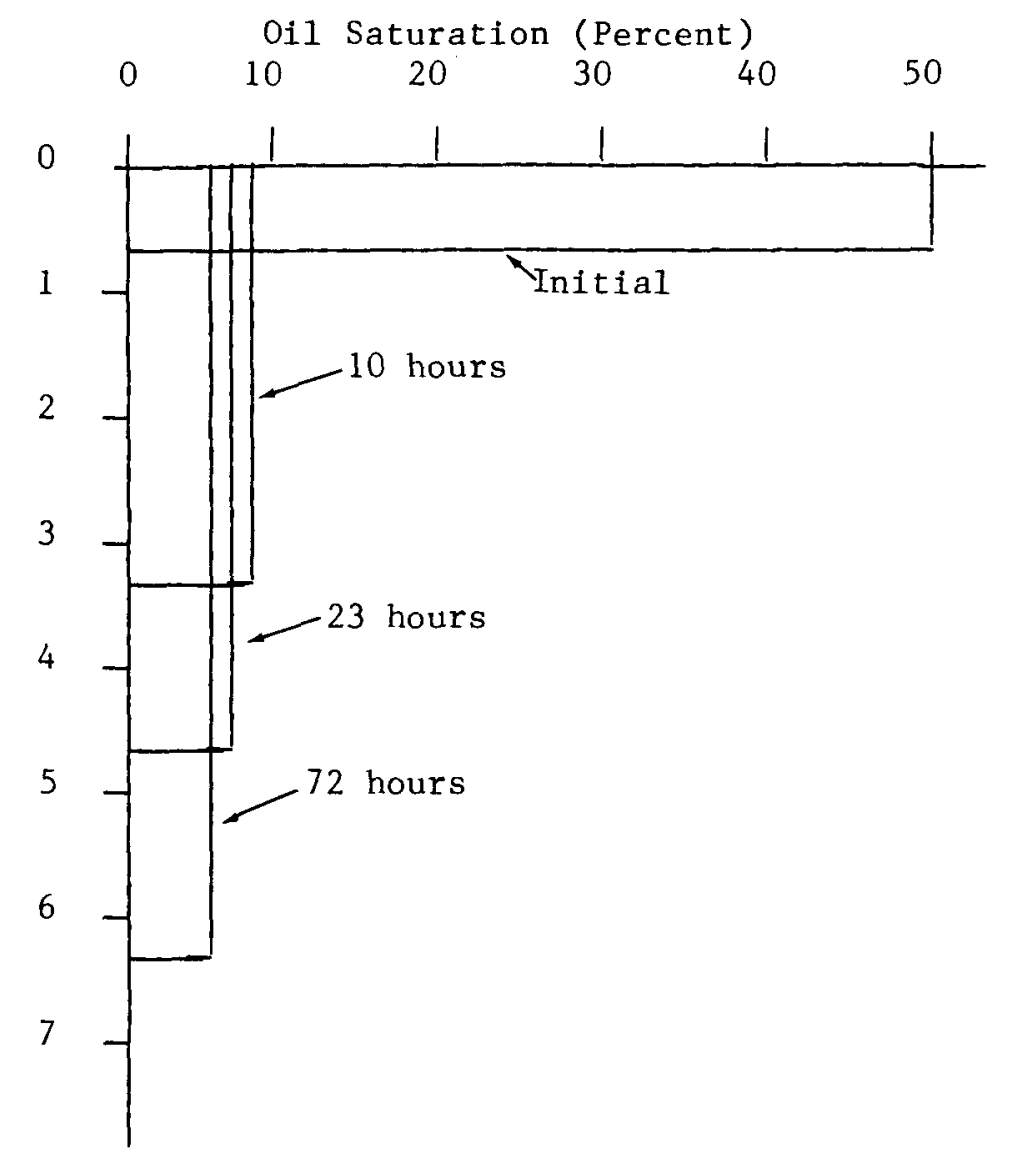

Figure 5.20. Results of Swiss experiments on oil saturation distribution in one soil as a function of time (ref. 31 ).

ranging from 500 to $1500 \mathrm{psi}$. Injection pressures are equal to or slightly greater than the natural formation pressure, but excessively high pressures are not used indiscriminately. A high pressure can cause fractures and fissures and can also cause brines to overwhelm semipermeable layers which lead to freshwater aquifers once a fracture occurs.

Flow of brine into aquifers depends on basically the same variables that control oil flow. For surface spills, the adsorption coefficient, soil porosity, rate of brine leakage, and distance to the aquifer play important roles in determining how fast brines will reach an aquifer. The extent to which brine can pollute an aquifer depends on the brine concentration and the chemical characteristics of the aquifer.

In direct releases from wells to aquifers, the pollutant concentration in the aquifers is a function of the distance traveled, the seepage velocity, aquifer porosity, dispersion constants, and the pollutant decay rate. Equations governing these cases and for brine travel through fissures and fractures may be found in ref. 33 . 
Chemical Characteristics of Brines. Rittenhouse et al. 34 suggest that elements in oil field waters commonly are present in the following concentration ranges.

Chemical Elements or Ions
$\mathrm{Na}, \mathrm{Cl}$
$\mathrm{Ca}, \mathrm{SO}_{4}$
$\mathrm{~K}, \mathrm{Sr}$
$\mathrm{Al}, \mathrm{B}, \mathrm{Ba}, \mathrm{Fe}, \mathrm{Li}$
$\mathrm{Cr}, \mathrm{Cu}, \mathrm{Mn}, \mathrm{Ni}, \mathrm{Sn}, \mathrm{Ti}, \mathrm{Zr}$,
$\mathrm{Be}, \mathrm{Co}, \mathrm{Ga}, \mathrm{Ge}, \mathrm{Pb}, \mathrm{V}, \mathrm{W}, \mathrm{Zn}$

Concentration
$>1000 \mathrm{ppm}$
up to $1000 \mathrm{ppm}$
$>100 \mathrm{ppm}$
$1-100 \mathrm{ppm}$
$\mathrm{ppb}$ (most brines)
$\mathrm{ppb}$ (some brines)

No significant relationship was found between brines and the minerals in aquifer rocks. The amounts and ratios of these constituents depend on the origin of the water and on the effects of human actions. During tertiary recovery, injection of organic chemicals in chemical floods increases the chemical concentration of certain constituents in brines to a small extent. The amount of dissolved constituents found in oil field brines range from less than $1 \times 10^{4} \mathrm{mg} / 1$ to over $3.5 \times 10^{5} \mathrm{mg} / 1$. Within a field the concentration can vary by a factor of 2 or more. 35 The exact locations of production wells affect the concentration of pollutants in brine. Although it is not possible to provide exact data on brine constituents, some inferences can be drawn from the geologic ages of oil fields. Table 5.6 shows the total dissolved solids values found in various parts of the U.S. and Canada.

Table 5.6

Total Dissolved Solids ${ }^{a}$ in Oil Field Brine Samples in the U.S. and Canada

\begin{tabular}{lcrrr}
\hline & $\begin{array}{c}\text { Number } \\
\text { of } \\
\text { Samples }\end{array}$ & \multicolumn{2}{c}{ Dissolved Solids $(\mathrm{g} / 1)$} \\
\hline Illinots Basin & 22 & 70 & 98 & 119 \\
Louisiana and Texas Gulf Coast & 79 & 30 & 69 & 131 \\
East Texas & 88 & 27 & 66 & 116 \\
North Texas & 24 & 173 & 222 & 241 \\
West Texas and New Mexico & 148 & 61 & 111 & 173 \\
Permian only & 74 & 70 & 143 & 215 \\
Pennsylvanian only & 34 & 80 & 115 & 168 \\
Silurian and Devonian only & 15 & 42 & 55 & 72 \\
Ordovician and Cambrian only & 21 & 53 & 67 & 128 \\
Anadarko Basinb & 118 & 51 & 137 & 203 \\
Wiliston Basin, post-Paleozoic & 25 & 9 & 59 & 88 \\
Williston Basin, Paleozoic & 55 & 115 & 173 & 296 \\
Powder River Basin & 22 & 3 & 5 & 11 \\
Other Wyoming & 28 & 4 & 5 & 11 \\
Colorado & 18 & 3 & 5 & 15 \\
California & 116 & 5 & 18 & 30 \\
Seawater & $?$ & $?$ & 35 & $?$ \\
\hline
\end{tabular}

a See ref. 34.

bIncludes Oklahoma Platform and Ardmore Basin.

Source: ref. 36. 
Chemicals Used in Tertiary Recovery. (Also see Section 5.8.) The potential exists for contamination of surface waters and aquifers by spills and leaks of EOR chemicals. Several reports have addressed environmental issues related to EOR chemicals, concluding that of the large list of substances which may be applicable, only a few will actually find widespread use. $1-7,37$ The most comprehensive review thus far of potential problems associated with the use of EOR chemicals has been published by the DOE Bartlesville Energy Technology Center (BETC). 38 More than 200 chemicals proposed for use in EOR were evaluated for toxicity and potential health effects based upon existing literature. The survey defined five groups of chemicals "whose members are of primary concern because of their widespread use and commercial availability" (see Table 5.7).38 It was generally concluded that health hazards could be posed to field personnel and to populations whose water sources may originate in aquifers underneath EOR fields. These hazards could be substantially reduced by close attention to safe handling and disposal praciices, and by strict adherence to appropriate regulations (e.g., for occupational health and safety; for underground injection control). It was also concluded that some chlorinated hydrocarbons used as biocides are sufficiently toxic such that their use should be avoided "if it can be shown that [their] exposure to either man or environment could occur despite all precautions." 38

The remainder of this section reports in condensed form the summary of findings published by the BETC. (The authors thank BETC Technical Project Officer, Michael Crocker, for permission to quote liberally from ref. 38, to which the reader is referred for detailed information.)

A. Micellar/Polymer Flooding Technology:

Mobility Control Agents (MCA's). Both the polysaccharide and polyacrylamide polymers used as MCA's can be considered to be essentially non-toxic. However, some health effects may occur due to the physical nature of the compounds used (i.e., broth or powder). Both polyacrylamide and polysaccharide powders are implicated as respiratory hazards because exposure to the polymer powders occurs at EOR facilities. Contamination from fermentation process residues and other debris in the powder may enhance the toxicity of these airborne dusts.. In addition, the physical nature of the powder particles themselves may allow adsorption of ambient toxic vapors with the particles, possibly providing a convenient vehicle for transporting toxic materials into the lungs.

Toxic stabilizing additives used to control biodegradation and subsequent loss of viscosity may be present at concentrations as high as $2000 \mathrm{ppm}$ in manufactured polymer broths. Acrolein, formaldehyde, and glutaraldehyde, which are primary irritants, are the most common of these. Contact with polymer broths should therefore be avoided.

Other MCA's (carboxymethylcellulose, hydroxyethylcellulose) are slightly irritating to eyes, skin, and mucus membranes. Butyl cellusolve (polyethylene glycol monobutyl ether) is a primary irritant by inhalation, although its low volatility reduces this 
Table 5.7

Survey Chemicals Arranged by General Use in EOR 38

Mobility Control Agents

Polyacrylamides

Xanthan gums

Carboxymethylce1lulose

Hydroxye thylcellulose

Polyethylene glycol monobutyl ether

Polyethylene oxide

Consurfactants

1-hexano1

2-hexano1

1 -octanol

2-octanol

n-butanol (and tert-, sec-, iso-isomers)

Cyclohexanol

Polyethoxya1kylphenol

Biocides, Chelating Agents, Oxygen Scavengers

Quaternary ammonium chloride

2,4,5-trichlorophenol

Pentachlorophenol

Phenol

2,2-dibromo-3-nitrilopropionamide

Copper sulfate

Glutaraldehyde

Formaldehyde

Sodium hypochlorite

Acrolein

EDTA

1,6-hexanediamine

Surfactants

Alky aryl sulfonates

e.g., Alkyl benzene sulfonate

Octadecyltoluene sulfonate

Tridecyl benzyl sulfonate

Decyl benzyl sulfonate

Alkyl naphthenic sulfonates

Petroluem sulfonates (toxiclty as groups)

Alkaline Flooding Agents, Preflush Agents, Thermal Enhancers

Sodium nitrate

Sodium hydroxide

Sodium orthosilicate

Sodium carbonate

Sodium borate

Sodium hydrosulfite

Sodium bisulfite

Sodium sulfate

Hydrazine

Quinoline

Toluene

Xylidine

Aniline 
hazard. Laboratory animals injected with subcutaneous implants of water-soluble polymer chemicals have developed localized skin tumors, but normal EOR applications should not involve this kind of contact, and these effects have never been reported in humans.

Cosurfactants. The most commonly used chemical cosurfactants are alcohols of $\mathrm{C}_{5}-\mathrm{C}_{12}$ fatty acids. The toxicity of this group is well documented and probably does not pose any real toxic hazard on site if the chemicals are handled properly and are not abused. The irritating nature of the vapors of these alcohols would most likely prevent overexposure and therefore reduce the likelihood of toxic hazards associated with these chemicals. However, inhalation of these vapors in conjunction with exposure to other chemicals may enhance or otherwise alter the toxicological effects of those chemicals.

Surfactants. Surfactants are used as component parts of micellar slugs used in micellar polymer flooding. The most commonly used surfactants are long chain linear alkyl sulfonates, alkyl aryl sulfonates, and petroleum sulfonates. Surfactants are toxic if ingested and are irritating to both eyes and skin. It is possible that the sulfonates could provide an efficient vehicle for the uptake of hazardous chemicals into the body because of their solubilizing ability. Thus, exposure to harmful chemicals may occur despite the most fastidious precautions. The sulfonates themselves are not fully characterized toxicologically. Both the petroleum and aryl species which are components of the sulfonates have demonstrated tumorigenicity. What this might mean to chronic toxicity of these chemcials is unclear.

Generally, sulfonation of petroleum and alkyl aryl fractions are carried out on the EOR site. This might result in unacceptably high amounts of worker contact with sulfonates. However, the epidemiological studies necessary to substantiate this conjecture remains to be performed. If trends continue towards maintaining surfactant mixing and injection in enclosed systems, then toxic hazards may be reduced commensurately. Nevertheless, the health hazard posed by this group of compounds may present a difficult problem to assess. The potential for synergistic actions with other chemicals included as part of micellar slugs may result in complex toxic hazards to exposed individuals. It has been suspected that petroleum sulfonates may react with polynuclear aromatic hydrocarbons (PAH's) thus presenting the possibility of introducing carcinogenic compounds into the recovery system. Besides, the sulfonation reaction used to produce these surfactants is reversible, therefore presence of the toxic parent compounds in produced fluids should be suspected.

Biocides and Bactericides. The toxicity to man and the environment of the various biocides and bactericides that are currently in use today is the subject of continuing research. The dangers of certain of these compounds are just coming to light. Particularly hazardous are the chlorinated phenols. Other phenolic compounds 
and most cyanogen-based compounds should also be considered as unusua1ly hazardous. The reason the phenolic compounds pose such problems is that both they and their metabolites are toxic. Their contaminants, such as dioxins and furans have potential long-term consequences in man and the environment. The high rate of bioaccumulation of these compounds in the fatty tissues of mammals and fishes suggests the possibility of long-term chronic effects. The chronic effects of the compounds in the body over years of exposure may eventually cause severe health problems including cancer, heart failure, and systemic disease. Phenol derivatives have been implicated in the etiology of several cancers. Al1 of these compounds persist in the environment and accumulate in fish and sediments. In addition, the contaminating species that are inherently present in pentachlorophenol and 2,4,5-trichlorophenol are probably more toxic than the parent compounds themselves. These include (generically): tetracholorophenols, chloroquinones, chlorodibenzodioxins, chlororesorcinols, and polychlorinated dibenzofurans. The dioxins have been implicated in several disorders including cancer, sterility, and retardation and malformation of of fspring.

Attempts are being made to "engineer" biocides and bactericides which are specific to enhanced oil recovery applications. If adequate substitutes can be synthesized which are not characterized by the high toxicity and carcinogenic potential of biocides like the chlorinated phenols, then every effort should be made to utilize these other agents.

\section{B. Miscible Carbon Dioxide Technology}

$\mathrm{CO}_{2}$ gas injected as part of the liquid slug may contain toxic $\mathrm{H}_{2} \mathrm{~S}$ and $\mathrm{SO}_{2}$ in concentrations of approximately 1 to $3 \%$. Both pose health hazards to personnel at the site if direct exposure were to occur. However, because the injection slug is already selfcontained mixed liquid gas composition, risk from this even occurring is low. Generally, the ancillary use of other chemicals such as surfactant foams appears to be minimal in the' application of this kind of we11-treatment because of the poor results expected in field trials.

\section{In Situ Combustion Technology}

Combustion agents such as hydrazine and quinoline used in this technology are either demonstrated or implicated carcinogens in rats and mice. It is extremely difficult to make valid quantitative judgement of the human carcinogenic risk associated with the use of these chemicals, although policy making princlples have been defined by the Environmental Protection Agency. Nevertheless, extreme care and consideration should be exercised in the handing and utilization of these chemicals.

Alkaline Flooding and Pre-Flush Technologies. Chemicals involved in these processes are caustic or acidic in nature and substantially toxic to humans. Most of the chemicals used in these 
processes have been utilized extensively in industry; however, the effects of long-term low-level exposure to these chemicals have not been evaluated. Major examples of caustic flooding agents are high $\mathrm{pH}$ alkalis (i.e., sodium hydroxide, sodium hydrosulfite, sodium bisulfite, sodium hypochlorite). Pre-flush agents include inorganic and organic acids, bases, and salts such as hydrochloric acid, sulfuric acid, sodium hydroxide, quaternary ammonium chlorides, sodium nitrate. Handling practices and working conditions in compliance with federal regulations at the EOR facility are critical to the safety of personnel coming into contact with these types of chemicals.

Steam Soak and Steam Drive Technology. Generally, chemicals used in this technology are restricted to use in $\mathrm{SO}_{\mathrm{x}}$ scrubbers and corrosion control. Because these functions are not unique to EOR but are utilized widely in the petroleum industry, the toxic hazards of these chemicals as associated with steam drive technology were not addressed. However, some thermal efficiency enhancers such as quinoline, which is sometimes involved in steam drive operations, are suspected carcinogens. Chronic inhalation exposure to toluene, also used to enhance thermal efficiency, has resulted in severe liver and kidney damage.

Water Standards and EOR Contamination. Drinking water standards proposed by EPA list several elements of concern (Table 5.8). The standards specify the acceptable concentration for these minerals in drinking water except for certain aquifers. The UIC program exempts aquifers which have been used previously for extensive injection, aquifers which are oil producers, and aquifers which are so badly contaminated that their rehabilitation and use as a drinking water supply would be impractical.

Barium and chloride are the two minerals of concern found in ofl field brines. Total dissolved solids are present in large concentrations also. Brine concentrations of chloride exceed the drinking water standards by several orders of magnitude; barium concentrations may of ten also exceed standards by a factor of 10 or more.

Sodium and boron concentrations become important if groundwater is being used for agriculture. Irrigation limits on boron are $0.75 \mathrm{mg} / 1$ and for sodium the limitation is based on a high sodium adsorption ratio. Boron and sodium can be major contaminants in cases of brine leakage to aquifers.

0il field brines contain several minerals which can sometimes be extracted economically. 18 Brines have been the principal source of lodine and bromine in the form of iodide and bromide salts. Magnesium and calcium are two other minerals which are currently recovered from brines. Production of Iithium for batteries is also being explored in the Smackover Formation. EOR production is generally accompanied by the production of large volumes of highly concentrated brines which may not all be used for reinjection and which could be a potential source of such minerals. Local economics and brine characteristics would dictate project feasibility, and each EOR field needs to be evaluated for its potential in this regard. 
Table 5.8

Primary Drinking Water Quality Standards

Parameters Maximum Levelt

Inorganic chemicals

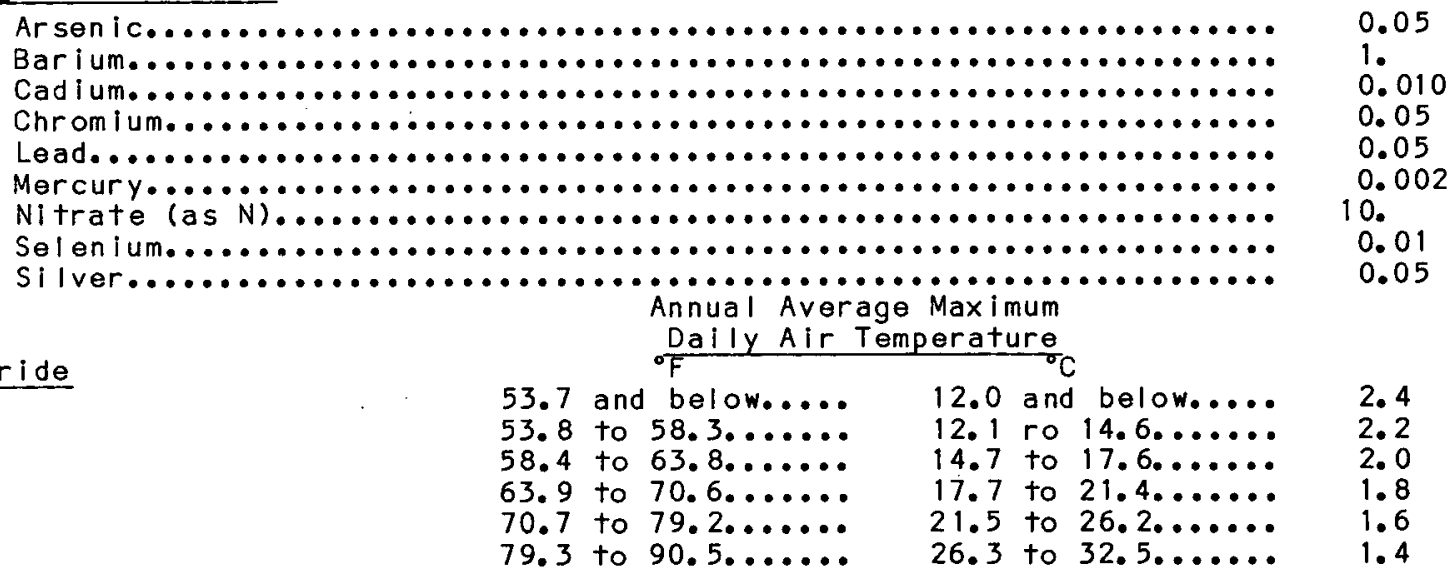

Chlorinated hydrocarbons

79.3 to $90.5 \ldots$

26.3 to $32.5 \ldots \ldots$

Endrin $(1,2,3,4,10,10$-hexachloro-6, 7-epoxy-1, 4,

$4 a, 5,6,7,8,8 a-o c t a h y d r o-1$,

4-endo-5, 8-dimethano naphthal ene

Lindane $(1,2,3,4,5,6$-hexachlorocyclohexane, gamma isomer)

Methoxychlor $(1,2,1$-trichlorethane) 2, 2-bits (p-methoxyphen 1$)$

Toxaphene ( $\mathrm{C}_{1} \mathrm{H}_{10} \mathrm{C} \mathrm{i}_{8}$-technical chlorinated camphene, 67-69\% chlorine) $(2,4,5-t r i c h l o r o p h e n o x y-p r o p i o n i c ~ a c i d)$

Turbidity (for surface water sources)

Collform bacteria

Membrane filter

technique:

$1 / 100 \mathrm{ml}$ mean/month

$4 / 100 \mathrm{ml}$ in one sample if $<20$ samples/month

$4 / 100 \mathrm{ml}$ in more than $5 \%$ if $>20$ samples/month

no coliforms in $<10 \%$ of portions/mongh

Fermentation tube with 10-ml portions:

no colliforms in $>3$ portions/sample if $<20 \mathrm{samples/month}$

no collforms in $>3$ portions of $5 \%$ of samples if $<20$ samples/month

Fermentation tube with 100-ml portions:

no collform bacterla in $>60 \%$ of portions/month

no colliform in 5 portions in one sample if $<5$ samples/month

no collform in 5 portions in $20 \%$ of samples if $>5$ samples/month

Radioactive material

Combined radium-226 and radium-228

Gross al pha-particle activity**

Beta-particle and photon radioactivity from man-made radionuclides

Tritium for total body

strontium-90 in bone marrow

Chlor ide

Color

Copper

MBAS***

$\mathrm{H}_{2} \mathrm{U}$

Iron

Manganese

Odor

$\mathrm{pH}$

Sulphate

Total dissolved solids

Zinc

Corrosian

$t_{\text {mg/l unless }}$ gtherwise stated.

* Includes Ra226 excludes radon, uranlum.

* If meet speclal requirements.

* * Methylene blue active substances.

Seurce: ref. 39 
Incidents of Contamination. Well failures and consequent groundwater contamination have been reported over the past few decades. The Texas Railroad Commission has 23,000 reports of surface- and ground-water contamination.1,2 However, at a workshop held in Bozeman, Montana, 6 it was suggested that the contamination caused by oil field activity has declined significantly in Texas since 1973. This is also confirmed by the Texas Water Development Board.25 Since 1973, brine disposal has been permitted into impervious subsurface pits only, thus reducing surface discharge from unlined brine pits.

Nevertheless, recent data gathered by the California Division of $0 i 1$ and Gas (CDOG) 26 would suggest that local incidents of groundwater contamination might be increasing rather than declining as suggested by Montana workshop participants.

Data were gathered by the CDOG as part of their application to the EPA for primacy over Class II injection wells. During 1980, they reported 124 deficiencies and seven violations (Table 5.9). A deficiency is defined as the failure of a we11's mechanical integrity; failure of an operator to perform required tests; failure to file data; or problems caused by injection operations in adjacent wells. A violation occurs when an operator fails to correct the deficiency within a specified period of time.

In 1980, packer problems accounted for two-thirds of all mechanical failures. As indicated in Table 5.10 a total of 36 failures occurred in 22,046 injection wells, a relatively sma11 number.

Table 5.9

Noncompliance Summary, 1980

\begin{tabular}{|c|c|c|c|c|c|c|c|}
\hline \multirow{2}{*}{$\begin{array}{c}\text { Type of } \\
\text { Noncompliance }\end{array}$} & \multicolumn{6}{|c|}{$\begin{array}{c}\text { Number of Deficiencies and Violations } \\
\text { Districts }\end{array}$} & \multirow{2}{*}{$\begin{array}{l}\text { State } \\
\text { Total }\end{array}$} \\
\hline & 1 & 2 & 3 & 4 & 5 & 6 & \\
\hline Excessive injection pressure & 52 & -- & 2 & -- & -- & -- & 54 \\
\hline Interference & -- & -- & 3 & -- & -- & -- & 3 \\
\hline \multicolumn{7}{|l|}{ Mechanical failure - } & 5 \\
\hline casing & 1 & -- & -- & 2 & 1 & 1 & 5 \\
\hline tubing & -- & -- & $:--$ & 3 & 1 & -- & 4 \\
\hline packer & 7 & -- & 1 & 9 & 3 & -- & 20 \\
\hline shoe & -- & -- & -- & 1 & -- & -- & 1 \\
\hline cement & 3 & -- & -- & -- & 2 & -- & 5 \\
\hline injection line & -- & -- & -- & 1 & -- & -- & 1 \\
\hline No injection survey & -- & 26 & $6 *$ & -- & -- & -- & 32 \\
\hline Data filing & -- & -- & $1 *$ & -- & -- & -- & 1 \\
\hline Totals & 68 & 26 & 13 & 16 & 7 & 1 & 131 \\
\hline $\begin{array}{l}\text { *Violations. } \\
\text { Source: Reference } 21 .\end{array}$ & & & & & & & \\
\hline
\end{tabular}


Table 5.10

Well Failure Summary, 1980

\begin{tabular}{|c|c|c|c|c|c|c|c|}
\hline \multirow{2}{*}{$\begin{array}{l}\text { Type of } \\
\text { Failure }\end{array}$} & \multicolumn{6}{|c|}{$\begin{array}{l}\text { Number of Well Fallures } \\
\text { California Oil Districts }\end{array}$} & \multirow{2}{*}{$\begin{array}{l}\text { State } \\
\text { Total }\end{array}$} \\
\hline & 1 & 2 & 3 & 4 & 5 & 6 & \\
\hline Casing & 1 & -- & -- & 2 & 1 & 1 & 5 \\
\hline Tubing & -- & -- & -- & 3 & 1 & - & 4 \\
\hline Packer & 7 & -- & 1 & 9 & 3 & -- & 20 \\
\hline Shoe & -- & -- & -- & 1 & -- & -- & 1 \\
\hline Cement & 3 & -- & -- & -- & 2 & -- & 5 \\
\hline Injection line & -- & -- & -- & 1 & -- & -- & 1 \\
\hline Total failures & 11 & 0 & 1 & 16 & 7 & 1 & 36 \\
\hline Total injection wells* & 2,431 & 691 & 1,474 & 16,561 & 771 & 28 & 22,046 \\
\hline Failures per 100 wells & 0.5 & 0 & 0. & 0 & & & 0. \\
\hline
\end{tabular}

*Active and shut down as of November 1980.

Source: References 21 .

In the last 40 years, CDOG records indicate that 32 cases of contamination have occurred in underground source drinking water (USDW) as a result of Class II well operations. Discovery of these cases resulted from CDOG surveillance work and from citizen and well operator complaints. In all but one case, the elapsed time from discovery to correction was less than one year.

A histogram of the number of contamination cases versus the years of occurrence appears in Figure 5.21. From 1940 to 1955, only two cases were reported--both in 1941. The source of this contamination was "improper practice." Between 1956 and 1960, five cases of cement failure and casing deterioration were reported. Since 1966, however, the number of cases has increased. During the past five years, 13 cases of contamination were reported.

Conversations with CDOG staff reveal several reasons for the increase in contamination, including improved monitoring techniques, the ages of wells, and the proximity of water users to ofl fields. These reasons have a direct bearing on EOR operations.

0il field operators prefer to use old oil wells for reinjection of disposal fluids. The well is usually cemented off below the brine injection zone, the casing is perforated at the injection formation, and the well is ready for brine injection. Although these old wells are supposed to be inspected to ensure that the seal is tight and acceptable, they are more likely to have casings corroded by ofl operations and to fail when corrosive brines are injected at high pressures.

In several Texas counties where the rights to groundwater by municipal, agricultural, and ofl producers are contested, water users are closer to ofl field operations and are affected by contamination before pollutants can be 


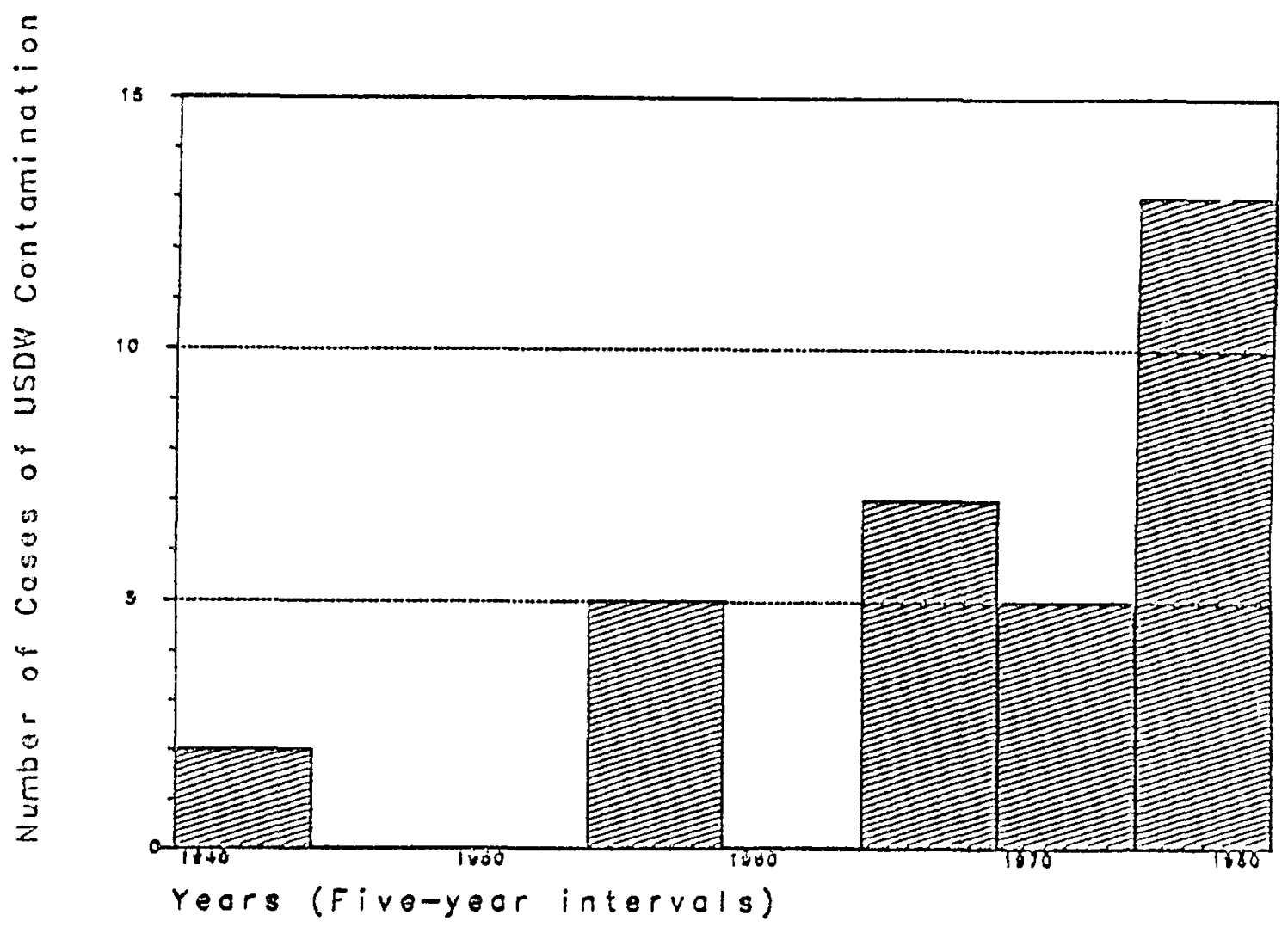

Figure 5.21. Underground source drinking water contamination (USDW) by date of occurrence (ref. 41).

diluted or degraded. Corrective measures are frequently urged by nearby users and required by state regulations before pollutants spread.

Similar data on USDW contamination are not now readily available in other states. Conversations with staff at the Texas Railroad Commission (TRC) revealed that the number of such cases is reportedly on the decline. 40 The injection pressure and volume of injected fluids are monitored monthly and reported annually to the TRC by the well operator. Between July 1979 and June 1980, 99 cases were investigated by TRC staff. Only one of these cases could be attributed to localized contamination from brine leakage.

Ground- and surface-water problems associated with oil production have also been observed in Pennsylvania. The most severe problems are in McKean, Warren, Forest, and Venango Counties. 42 Numerous complaints have been filed by Derrick City residents regarding groundwater contamination caused by oil drilling activity. Groundwater samples taken in 1979 in Foster Township in the vicinity of Derrick City showed : unusually high concentrations of chlorides, calcium, and sodium, apparently the result of inadequate disposal of the produced water (salt brines) from oil wells and water flooding operations. High concentrations of iron and manganese above the maximum contaminant levels established in the National Secondary Drinking Water Regulations are also indicated. 43 All water samples also contained petroleum in concentrations great enough to affect taste and odor. 
Some conclusions can be drawn from detailed examination of causes of contamination. Age of injection wells and proximity to users should be evaluated carefully to reduce the potential for contamination. Other factors, such as aquifer characteristics, types of disposal formation, and geological characteristics, also play a part in determining contamination potential. A more detailed discussion of groundwater contamination is found in Appendix A.

Conclusions. Groundwater contamination can be caused by spill and leakage of brine, oil, and chemicals used in enhanced oil recovery. The mechanisms by which contamination may occur are easily understood. The likelihood that contamination may occur during enhanced oil recovery is site or well specific. No generalizations can be drawn that may be applicable to an entire oil field or reservoir, or aquifer, because of the site-specific nature of the contamination mechanism.

Anecdotal information on contamination incidents is available in every oil-producing state. Some verifiable quantitative data on groundwater contamination by oil field activity are available for California and Pennsylvania where contamination is primarily due to leakage of brine from disposal wells. Data for California and Pennsylvania indicate an increasing number of contamination cases each year in old wells used for brine disposal. With increasing EOR production more brine will have to be disposed of, thereby increasing the risk of contamination.

\subsection{AIR QUALITY}

\subsubsection{Sources of Pollution}

Steam generators currently used in oil fields produce 75 to $85 \%$ quality steam and differ from typical industrial boilers in that they are fired with crude oil produced at the site. These generators are commonly once-through units burning lease crude at 80 to $91 \%$ efficiency. 44 Three barrels of oil are usually produced for each barrel burned; net production is thus two barrels. It is expected that some EOR steam generators will use coal in the future. Hence, each barrel of crude replaced by an equivalent amount of coal would result in a $50 \%$ increase in net oil production. Most steam injection projects are now located in Kern and Monterey Counties in California, where crude contains 1 to $2 \%$ sulfur and is relatively high in trace metals. 45 Using either oil or coal, these generators emit nitrogen oxides, sulfur oxides, particulate matter (including trace metals), carbon monoxide, hydrocarbons, and hydrogen sulfide.

Individual steam generator units commonly used in thermal enhanced oil recovery (EOR) operations come in two sizes: $20 \mathrm{MMBtu} / \mathrm{hr}\left(\mathrm{MM}=10^{6}\right)$ and 50 MMBtu/hr. They are usually manifolded together into a common forced draft fan leading to emission control units. A typical combination of units would result in a target heat output of $300 \mathrm{MMBtu} / \mathrm{hr}$, operating at close to full load ( 80 to $95 \%$ of rated capacity). Excess $0_{2}$ levels vary between 3 and $8 \%$ (see paragraph below on $\mathrm{NO}_{\mathrm{x}}$ control). Thermal enhanced oil recovery (TEOR) steam generators are designed to operate satisfactorily with zero hardness feedwater, containing up to $12,000 \mathrm{mg} / 1$ ( $\mathrm{ppm}$ ) of total dissolved solids (TDS) at temperatures ranging from $60^{\circ}$ to $220^{\circ} \mathrm{F}$. Water quality is a major factor 
for TEOR (as well as for all other applications) steam generators; vaporization of waters with high TDS concentrations consistently leads to boiler tube burnouts. TEOR steam generators must respond to dramatic changes in load demand due to injection requirements and must operate largely unattended.

Emissions from typical 10 and $50 \mathrm{MMBtu} / \mathrm{hr}$ steam generators were determined by Ryckman et al.44 (Table 5.11). Emissions for the larger unit are compared with data from other sources (Table 5.12), expressed in pounds of pollutant per 1000 gallons of burned fuel. Particulate compositions are shown in Table 5.13. These tables report information for specific steam generators using lease crudes from several oil fields in Kern and Monterey (CA) Counties. Emissions from other equipment using different lease crudes (or coal, see below) will, of course, be different.

As discussed previously, one barrel of crude is typically burned to produce three barrels of tertiary oil, for a net production of two barrels. Eventually, the cost for the equivalent energy content in one bbl of crude (approximately $6 \mathrm{MMBtu}$ ) will probably become lower for other fossil fuels such as coal. However, the cost advantage not withstanding, the abundance of U.S. coal compared to the decreasing domestic supplies of oil would tend to favor substitution of coal for oil in TEOR steam generators. Coal-fired generators are not new to oil production. Thus burning one-quarter ton of coke or bituminous coal, or one-half ton of lignite would place an additional barrel of tertiary crude in the marketplace. Uncontrolled emissions for coa1-fired burners comparable in size to those now used for TEOR are shown in Tables 5.12 and 5.13. With an ash content of approximately $10 \%$, emissions of total suspended particulates from coal would be comparable with those emitted by crude with $1 \%$ sulfur content. All other emissions from coal are greater than those for oil. The use of coal would entail additional environmental issues (e.g., coal storage; coal pile runoff; land disturbances and other problems for transportation systems; emissions regulations) and emission control equipment (e.g., precipitators). These items are discussed below. Potential coal-firing systems include fluidized bed combustors (FBC). A recently published report47 discussed the application of a multi-solid fluidized combustor (developed by Battelle Columbus Laboratories) to a small existing steam generator of the generic type widely used in TEOR.

Other sources of air pollution from TEOR involve compressors and well vents. Compressors, used in fireflooding to inject air into the producing formation, are usually driven by electric motors or natural gas-fired reciprocating engines. Heat and steam are produced when the injected air and in situ gas and oil are ignited. Both firefloods and steamfloods produce well vent emissions which are primarily water vapor (containing condensible and noncondensible hydrocarbons), particulates, hydrogen sulfide, and mercaptans. Sulfur pollutants vary according to the producing formation undergoing EOR.

Fireflood compressor emissions shown in Table 5.14 are based upon very limited field data 45 as well as EPA information. 46

Typical well vent emissions in Kern County, CA, are shown in Table 5.15. Larger TEOR operators, using a network of collection lines which connect to each wellhead, pipe escaping steam and gas into a cooling tower 


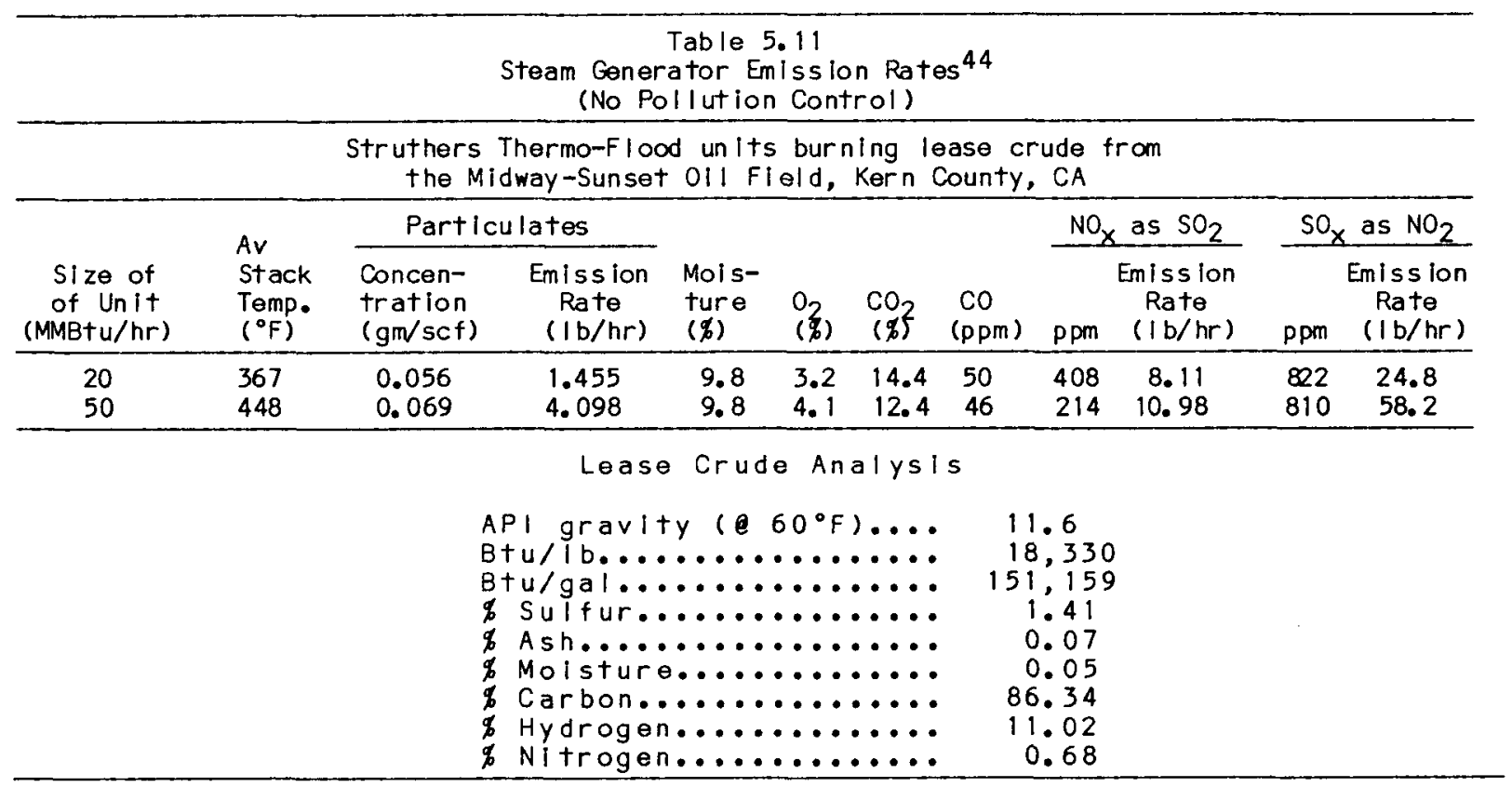

\section{Table 5.12}

Uncontrolled Emission Factors for Major Pollutants from 50-MMBtu/hr Oil Field Steam Generators

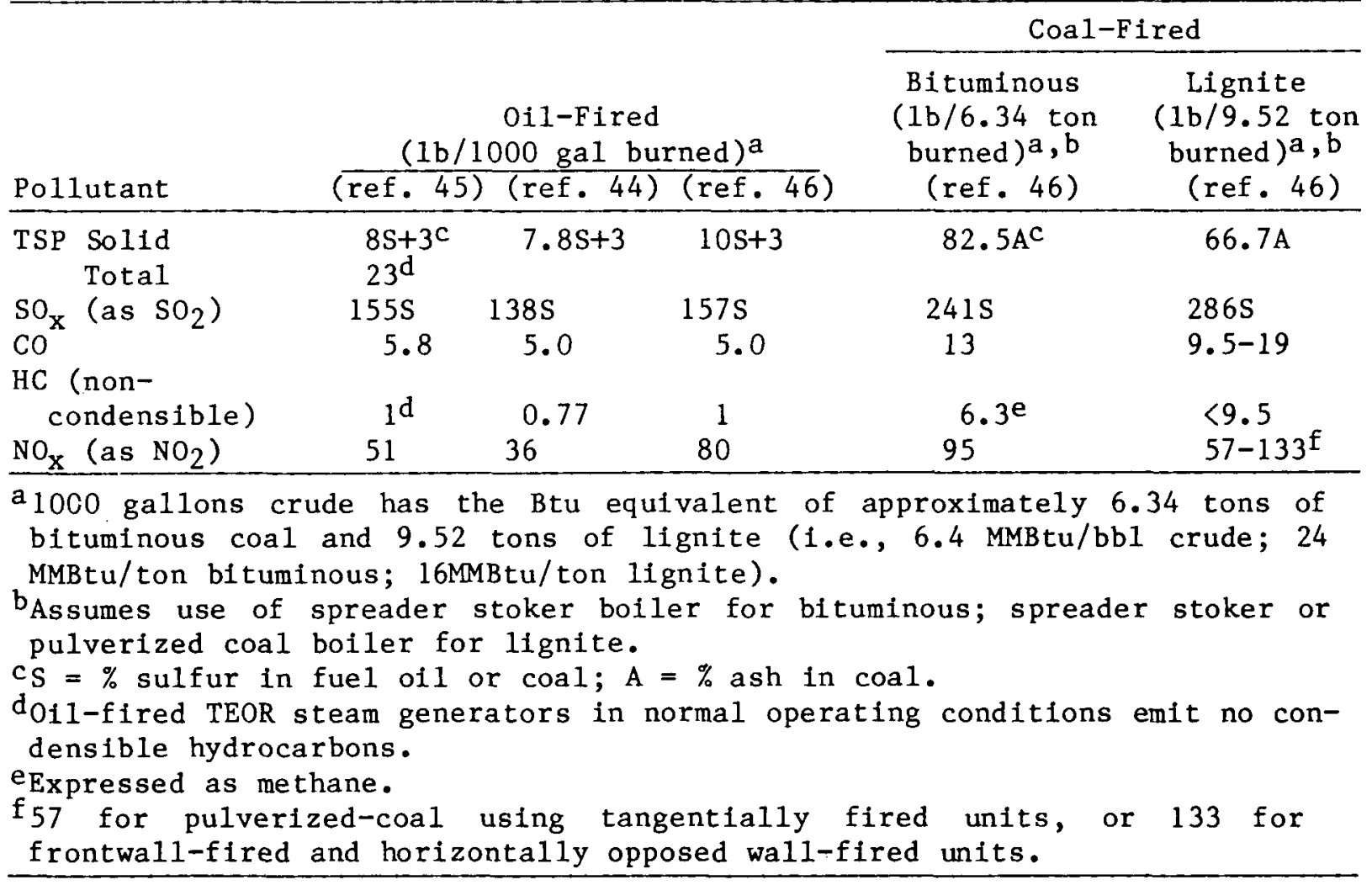




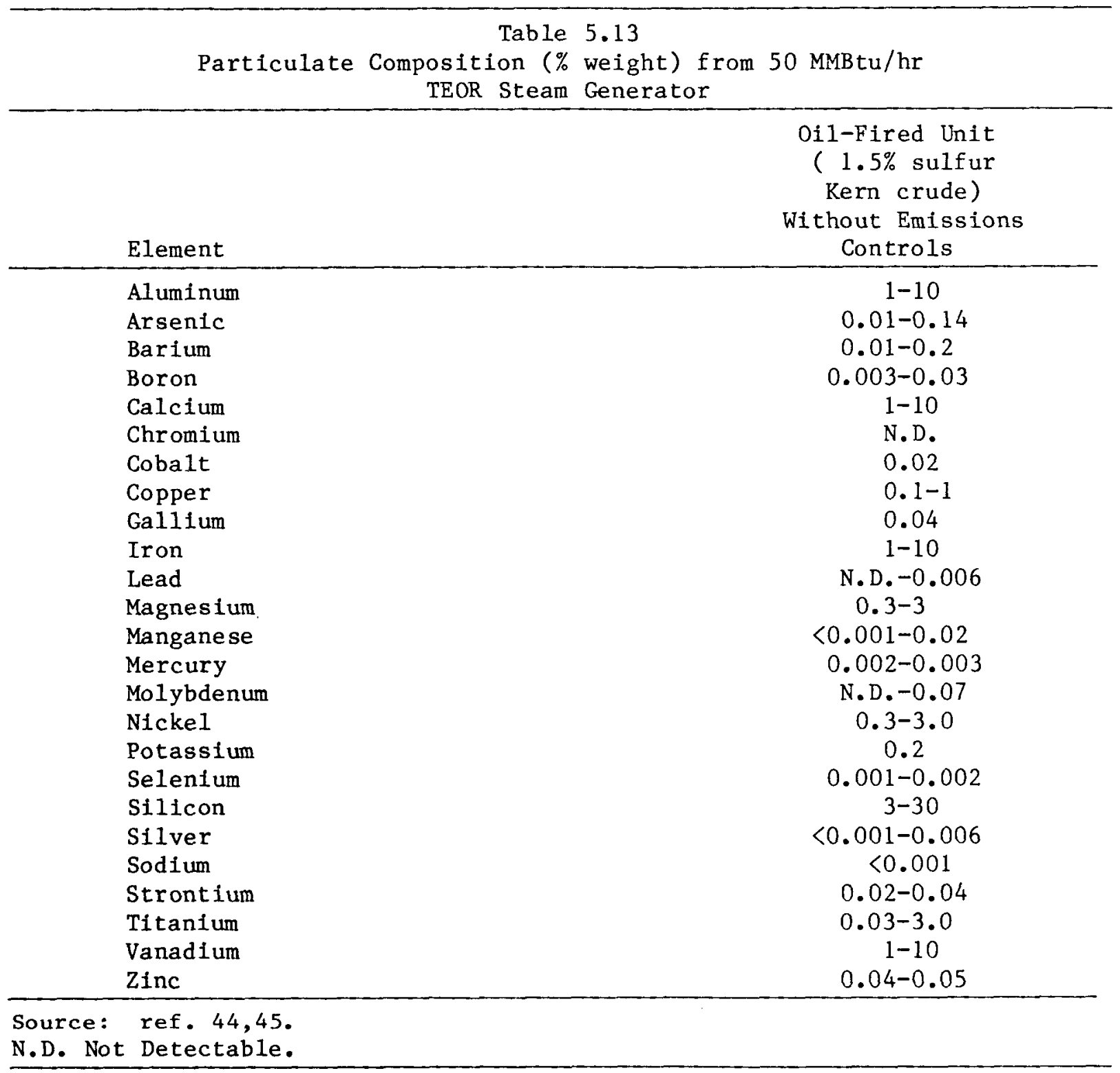

where they are condensed into liquids and separated. Marketable gases are added to natural gas delivery lines, and condensed oils are added to produced crude ofl. In 1979 about $39 \%$ of the total crude production (76.1 MMbb1) were produced in Kern County 48 as a result of cyclic steam injection and steamflooding. Using an average, value of $0.121 \mathrm{~b}$ of condensed HC per barrel of crude produced and an average of $340 \mathrm{lb}$ condensible $\mathrm{HC} / \mathrm{bbl}$ of crude, there would be an estimated recoverable $27,000 \mathrm{bbl}$ of oil equivalent which might ordinarily have been vented to the atmosphere.

\subsubsection{Emission Controls}

Nitrogen Oxides. $\mathrm{NO}_{\mathrm{x}}$ emissions from steam generators can be most easily controlled by careful regulation of both temperature and air/fuel ratio, by 
Table 5.14

Air Emissions from Compressors at Kern County, CA, Fireflood45,46

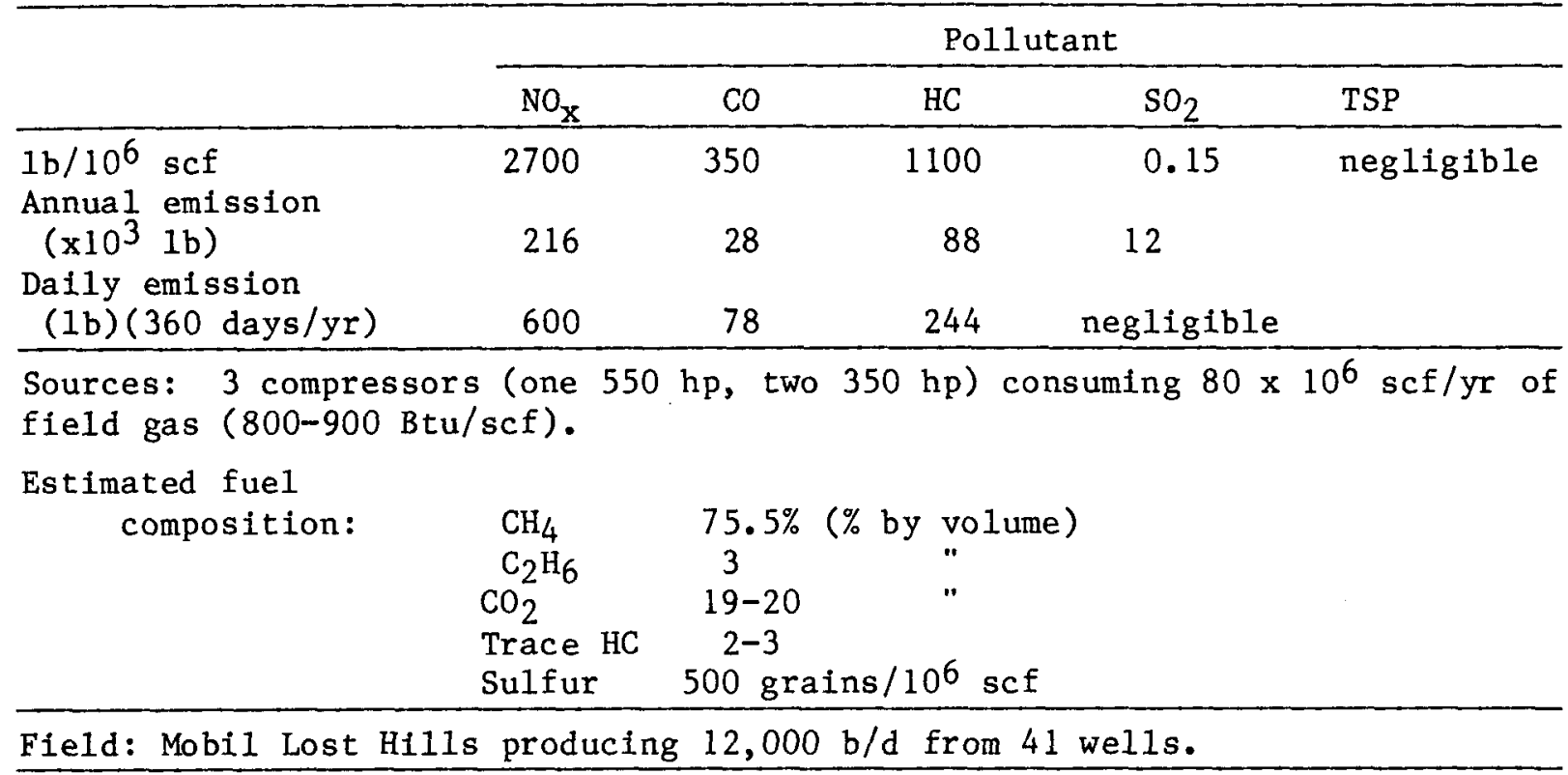

use of low $\mathrm{NO}_{\mathbf{x}}$ burners, by control of flame shape and impingement on tubes, as well as by ammonia injection, catalysis, and exhaust gas recirculation. $\mathrm{NO}_{\mathrm{x}}$ emissions from internal combustion engines driving fireflood compressors are controlled by standard techniques, namely engine modifications (e.g., improved carburetion) or exhaust treatment (e.g., catalytic convertors).

Emissions of nitrogen oxides from TEOR steam generators (1.e., NO and $\mathrm{NO}_{2}$ ) are controlled by modifying combustion processes or by flue gas treatment. The simplest combustion modification entails operating at the lowest possible excess air (i.e., oxygen) concentration. Results of a study controlling $\mathrm{O}_{2}$ in both 20- and 50-MMBtu/hr boilers used by Santa Fe Energy Corp. illustrates both decreasing $\mathrm{NO}_{x}$ and increasing $\mathrm{CO} / \mathrm{CO}_{2}$ concentrations as excess $\mathrm{O}_{2}$ is decreased (Table 5.16). It should be noted that the peak flame temperature increases as $\mathrm{O}_{2}$ in the flame zone decreases; and higher temperatures enhance $\mathrm{NO}_{x}$ production. Because TEOR steam generators are left unattended for long time periods, and in order to decrease maintenance servicing, excess $\mathrm{O}_{2}$ levels are usually set at 4 to $5 \%$. Reducing these $\mathrm{O}_{2}$ levels to $2 \%$ results in estimated reduction in $\mathrm{NO}_{\mathrm{x}}$ emissions by 10 to $15 \%$, with simultaneous fuel savings of $1 \% .49$ Equipment such as an oxygen concentration analyzer and closed-loop oxygen regulators are required to provide such $\mathrm{O}_{2}$ control, which can ultimately reduce $\mathrm{NO}_{x}$ emissions by 25 to $60 \%$. The Western Oil and Gas Association, and some oil companies, have testified 50 that $\mathrm{O}_{2}$ control is a proven technology capable of operating steam generators within a range of 1 to $2 \% \mathrm{O}_{2}$ excess when used in combination with low $\mathrm{NO}_{\mathbf{x}}$ burners (LNBS). Such a combination reportedly achieved 225 to $230 \mathrm{ppm} \mathrm{NO}$ on a 50 $\mathrm{MMBtu} / \mathrm{hr}$ generator firing 0.7 to $0.8 \%$ nitrogen crude with $1.5 \% \mathrm{O}_{2}$. (At lower $\mathrm{O}_{2}$ levels, $\mathrm{NO}_{\mathrm{x}}$ emissions of 210 to $215 \mathrm{ppm}$ were achieved.) 
Table 5.15

Kern County, CA, Oil Well Vent Emissions 45

( $1 \mathrm{~b} / \mathrm{bbl}$ crude produced)

\begin{tabular}{lcc} 
& \multicolumn{2}{c}{ Field (and Producer) } \\
\cline { 2 - 3 } Pollutant & $\begin{array}{c}\text { Midway Sunset } \\
\text { (Santa Fe) }\end{array}$ & $\begin{array}{c}\text { Lost Hills } \\
\text { (Mobil) }\end{array}$ \\
\hline Total particulates & 0.095 & 0.15 \\
$\quad$ (condensable HC) & $(0.090)$ & $(0.15)$ \\
HC (noncondensable) & 0.0004 & 0.23 \\
Total HC (condensable & 0.09 & 0.38 \\
noncondensable) & 0 & 0.03 \\
$\mathrm{SO}_{2}$ & 0 & 0.002 \\
$\mathrm{CO}^{\mathrm{NO}}$ & 0 & 0 \\
$\mathrm{H}_{2} \mathrm{~S}$ & 0.0003 & 0.03 \\
\hline $\begin{array}{l}\text { Caveat: "The data are based on very few tests and should be } \\
\text { treated as qualitative indicators of emissions." }\end{array}$ \\
\hline
\end{tabular}

Several manufacturers make LNBs for which substantial $\mathrm{NO}_{\mathrm{x}}$ reductions are claimed. LNBs are classified as controlled (i.e., good mixing) or staged combustion types. The former control injection patterns and atomize injection of the fuel into the combustion air, with several mixing and postcombustion zones. In addition to improving fuel mixing, these LNBs use cooler combustion gases to quench the flame, thereby reducing $\mathrm{NO}_{\mathrm{x}}$ emissions by 30 to $40 \%$ compared to conventional burners. Fuel efficiencies of 0.5 to $2 \%$ also result. Two corporations reportedly achieved $\mathrm{NO}_{\mathrm{x}}$ emissions of 150 to $165 \mathrm{ppm}$ using TRW LNBs on 80-MMBtu/hr burners (fuel nitrogen content was not reported but was expected to be in the range 0.2 to $0.3 \%) .49$

Staged-combustion-type LNBs react fuel with less than the stoichiometrically necessary amount of air. Secondary air is added in the furnace after the air/fuel mixture has been cooled in passage over water/steam tubes. Flue gases are recirculated to mix with combustion air in multiple flame zones. Claims for $\mathrm{NO}_{\mathrm{x}}$ concentrations from such devices range from 250 to 150 ppm or lower. 45 The California Air Resources Board (CARB) estimates that such LNBs would pay for themselves in less than three years and would allow TEOR operators to use their equipment more efficiently.

$\mathrm{NO}_{\mathrm{x}}$ emissions may also be reduced by treating flue gases. One process ("Thermal DeNO ${ }_{x}$ ) uses ammonia to react with nitrogen oxides in the flue gas to form nitrogen and water. This is done in the temperature range $1600^{\circ}$ to $1800^{\circ} \mathrm{F}$, where no catalyst is required. Hydrogen can be injected with the ammonia to improve the $\mathrm{NO}_{\mathbf{x}}$ reduction efficiencies by enhancing reaction rates at reduced temperatures, but this may not be necessary for TEOR steam generators. $45 \mathrm{NO}_{\mathrm{x}}$ effluent reduction is a function of flue gas temperatures and $\mathrm{NH}_{\mathrm{x}} / \mathrm{NO}_{\mathrm{x}}$ molar ratios. While $\mathrm{NO}_{\mathrm{x}}$ reductions as high as $95 \%$ have been achieved under controlled laboratory conditions, 51 reductions in the range of 40 to $70 \%$ occur under field conditions. Two oil field operators have 
Table 5.16

Steam Generator Emissions 44

Struthers Thermo-Flood units burning lease crude from the Midway Sunset 0il Field, Kern County, CA

\begin{tabular}{|c|c|c|c|c|c|}
\hline & $\begin{array}{cl}\mathrm{O}_{2} & \begin{array}{l}\text { Setting } \\
(\%)\end{array} \\
\end{array}$ & $\begin{array}{l}\mathrm{CO}_{2} \\
(\%)\end{array}$ & $\begin{array}{c}\mathrm{CO} \\
(\mathrm{ppm})\end{array}$ & $\begin{array}{r}\mathrm{NO}_{\mathrm{x}} \\
(\mathrm{ppm})\end{array}$ & Smoke \\
\hline \multicolumn{6}{|l|}{$20 \mathrm{MMBtu} / \mathrm{hr}$ unit } \\
\hline & 3.7 & 13.0 & 20 & N.D.* & none \\
\hline & 3.0 & 14.0 & 25 & N.D. & none \\
\hline & 2.0 & 14.5 & 25 & N.D. & none \\
\hline & 1.0 & 15.0 & 30 & N.D. & light \\
\hline & 0.1 & 0 & 120 & N.D. & very heavy \\
\hline \multicolumn{6}{|l|}{$50 \mathrm{MMBtu} / \mathrm{hr}$ unit } \\
\hline & 5.0 & 12.0 & 0 & 9.4 & none \\
\hline & 4.0 & 12.8 & 0 & & none \\
\hline & 2.0 & 13.4 & 0 & & none \\
\hline & 1.6 & 14.0 & 60 & & light \\
\hline
\end{tabular}

* No data reported.

received CARB authorization to construct seventy-five 50-MMBtu/hr steam generators having Thermal DeNO $_{x}$ units.

Ammonia injection with selective catalysts (e.g., platinum, copper su1fate, titanium oxides, vanadium oxides) has resulted in $\mathrm{NO}_{x}$ emission reductions of 80 to $95 \%$ in laboratory applications. Catalysts are degraded quickly by poisons, by particulate coatings, or by reactions with sulfur oxide. Lifetimes may be less than one year for high sulfur-content oil and coal fuels.

These technologies are summarized in Table 5.17. From reported test data and other information available in the literature, it appears that control technologies exist which can reduce $\mathrm{TEOR} \mathrm{NO}_{\mathrm{x}}$ emissions from ofl-fired steam control generators to less than $100 \mathrm{ppm}$.

Sulfur 0xides. Sulfur oxides from TEOR derive strictly from the fuel used to produce steam. This is in contrast to nitrogen oxides, which come from nitrogen in both fuel and air during combustion. To reduce sulfur emissions, one may either reduce sulfur in the fuel or remove it from flue gases. The latter is commonly termed flue gas desulfurization (FGD).

The sulfur content in oil and coal varies depending on the producing reservolr or coal seams, respectively (Table 5.18). Thus the easiest way to reduce sulfur emissions is to use lower sulfur oil or coal. This is clearly unrealistic, however, since there is no reason to use low sulfur lease crude from another oil field, or to use low sulfur coal from distant areas, especially when these are more beneficially (and economically) used to fuel large utility and industrial boilers in other applications. 
Table 5.17

$\mathrm{NO}_{\mathrm{x}}$ Control Technologies

Uncontrolled baseline: $\left.50-\mathrm{MMBtu} / \mathrm{hr} \quad \begin{array}{l}0.7 \% \\ 0.9 \%\end{array}\right\} \mathrm{N}$ in oil results in $\left\{\begin{array}{l}250-300 \mathrm{ppm} \mathrm{NO}_{\mathrm{x}} \\ 314\end{array}\right.$

\begin{tabular}{|c|c|c|}
\hline Emissions Control & $\begin{array}{l}\text { Expected } \mathrm{NO}_{\mathrm{x}} \\
\text { Reduction, } \%\end{array}$ & Comments \\
\hline Excess $\mathrm{O}_{2}$ control & $25-60$ & $\begin{array}{l}\text { Burner may smoke because of varia- } \\
\text { tion in lease crude composition and } \\
\text { purity. }\end{array}$ \\
\hline $\begin{array}{l}\text { Low excess air burner } \\
\text { with ammonia injection }\end{array}$ & $70-82$ & $\begin{array}{l}\text { Cost benefits for clusters of units/ } \\
\text { users sharing ammonia storage and } \\
\text { feed units. }\end{array}$ \\
\hline Ammonia with catalyst & $80-95$ & $\begin{array}{l}\text { Control of residence time is diffi- } \\
\text { cult; low catalyst lifetimes ( }<1 \text { yr } \\
\text { for high-sulfur oil or coal). Cost } \\
\text { reductions for clusters of units. } \\
\text { Users to share ammonia storage and } \\
\text { feed units costs. }\end{array}$ \\
\hline Low $\mathrm{NO}_{\mathrm{x}}$ burner & 60 & \\
\hline Staged combustion & $30-70$ & $\begin{array}{l}\text { Not yet applied to TEOR steam } \\
\text { generators. } 45\end{array}$ \\
\hline
\end{tabular}

Table 5.18

Characteristics of $0 i 1$ and Coal Types

\begin{tabular}{|c|c|c|c|c|c|}
\hline \multirow[t]{2}{*}{$0 i 1$} & \multicolumn{5}{|c|}{ Coal } \\
\hline & Type & $\begin{array}{c}\text { Bituminous } \\
\mathrm{TX}, \mathrm{OK} \\
\end{array}$ & $\begin{array}{l}\text { Anthra- } \\
\text { citic }\end{array}$ & $\begin{array}{l}\text { Subbituminous } \\
\text { AR, UT, WY }\end{array}$ & $\begin{array}{c}\text { Lignite } \\
\text { ND* } \\
\end{array}$ \\
\hline & $\begin{array}{l}\% \text { Moisture } \\
\% \text { Volatile }\end{array}$ & $3-10$ & $2-5$ & $6-26$ & 37 \\
\hline & $\begin{array}{l}\text { Matter } \\
\% \text { Fixed }\end{array}$ & $25-35$ & $2-11$ & $39-43$ & 27 \\
\hline & Carbon & $40-60$ & $67-84$ & $41-47$ & 32 \\
\hline & $\%$ Ash & $8-12$ & $10-20$ & $7-12$ & 4 \\
\hline $\begin{array}{c}0.1-5.0 \\
19-20\end{array}$ & $\%$ Sulfur & $\begin{array}{c}2-3 \\
11-14\end{array}$ & $\begin{array}{c}0.06-0.08 \\
12-13\end{array}$ & $0.5-0.7$ & 0.4 \\
\hline
\end{tabular}

Available FGD systems span a wide range of effectiveness and cost. Each system reacts minerals containing calcium, sodium, or other materials with sulfur in the exhaust stream to form insoluble precipitates which may then be removed to a landfill, injected underground, or sold as a marketable product. Except for the last, however, a solid waste problem is substituted for an air emission problem; in either case, applicable regulations must still be met. 
The simplest FGD systems utilize connate (i.e., produced) waters containing calcium salts or other minerals which react with sulfur oxides in flue gases to form $\mathrm{SO}_{4}$ and $\mathrm{SO}_{3}$ precipitates. This is done in several California oil fields, where the precipitates are pumped back into underground formations. The San Ardo field uses such a method and estimates $80 \%$ sulfur removal. 45

Other scrubber systems are more technologically involved, and are surveyed periodically by EPA. In 1979, for example, 74 out of 123 existing identified FGD units were installed on steam generators used in California TEOR. An additional 80 units were planned, under construction, or begun in 1979.52

Over $95 \%$ of industrial FGD units are of the once-through sodium type. Such systems commonly use sodium hydroxide or sodium carbonate as the scrubbing medium, are less complex, and require lower capital investment than other FGD processes. They are most commonly found on small oil- or coa1fired steam generators. Scrubber effluent contains a mixture of sodium salts. For larger generators, dual-alkali systems are preferred. Using a clear sodium alkali solution for $\mathrm{SO}_{2}$ removal, dual-alkali processes produce sulfite and sulfate sludge for disposa1. Liquid wastes from once-through scrubbers are generally disposed of in evaporation ponds, well injection, and wastewater treatment. The dual-alkali systems use landfills for dewatered slurry or sludge.

In their 1979 survey, EPA found once-through sodium units achieving greater than $95 \% \mathrm{SO}_{2}$ removal, with dual-alkali systems reporting even higher removal capabilities.53 Tables $5.19 \mathrm{~A}$ and $5.19 \mathrm{~B}$ present results of the 1979 survey for both existing or planned FGD units.

Particulates. Particulate emissions are primarily associated with steam generators, though they are also produced as condensible hydrocarbons from well vents. Table 5.12 shows that particulate emissions from burning crude oil are lower than emissions in burning coal. There are many commercially proven systems to control particulates from steam generators, e.g., baghouses, wet, dry, or slurry scrubbers, and electrostatic precipitators.

The simple water scrubber in the San Ardo field provided $95 \%$ TSP removal, thanks to the low ash content of the lease crude used in the steam generator. Better than $95 \%$ removal of particulate matter may be achieved using a baghouse together with the dry alkali or spray dry systems described in the previous section.

Using a new baghouse design applied to a 25 MW utility boller (fired by low-sulfur pulverized coal), Yeager 54 illustrated a $99+\%$ particulate removal efficiency. A similar efficiency was shown for a shaker-stoker baghouse on a 12-MW coal-fired utility boiler. Total emissions from these units were 0.0015 and $0.0031 \mathrm{~b} / \mathrm{MMBtu}$, respectively.

Hydrocarbons. Hydrocarbon emissions come primarily from well vents. Asmentioned previously, large operators typically connect well vents with a piping network to collect emissions. Condensible hydrocarbons are decanted 
Table 5.19A

EPA 1979 Industrial Boiler FGD Survey 53

Thermal EOR Scrubbers Operating Throughout 1979

\begin{tabular}{|c|c|c|c|c|c|c|c|}
\hline $\begin{array}{l}\text { Company Name } \\
\text { and Location } \\
\text { (Vendor) }\end{array}$ & $\begin{array}{l}\text { Start- } \\
\text { Up Date } \\
\end{array}$ & $\begin{array}{l}\text { No. of } \\
\text { Boilers }\end{array}$ & $\begin{array}{l}\text { No. of } \\
\text { FGD } \\
\text { Units } \\
\end{array}$ & $\begin{array}{l}\text { Capacity } \\
(\text { scfm })\end{array}$ & $\begin{array}{l}\text { Process } \\
\text { Type* }\end{array}$ & $\begin{array}{l}\text { \% Sulfur } \\
\text { in Crude } \\
\text { Oil Fue1 } \\
\end{array}$ & $\begin{array}{c}\text { Design } \mathrm{SO}_{2} \\
\text { Removal } \\
\text { Efficiency } \\
(\%) \\
\end{array}$ \\
\hline $\begin{array}{l}\text { Texaco, Inc. } 46 \\
\text { San Ardo, CA } \\
\text { (Ceilcote) }\end{array}$ & $11 / 73$ & 29 & 29 & $\begin{array}{c}347,000 \\
\text { total }\end{array}$ & $\begin{array}{l}\text { Sodium } \\
\text { hydroxide }\end{array}$ & 1.7 & 73 \\
\hline $\begin{array}{l}\text { Mobil oil Co. } 46 \\
\text { San Ardo, CA } \\
\text { (in-house design) }\end{array}$ & 74 & 28 & 28 & $\begin{array}{c}175,000 \\
\text { total }\end{array}$ & $\begin{array}{l}\text { Sodium } \\
\text { hydroxide }\end{array}$ & $2.0-2.25$ & 90 \\
\hline $\begin{array}{l}\text { Getty Oil Co. } \\
\text { Cat Canyon Field } \$ 8 \\
\text { Generator, } \\
\text { Santa Maria, CA } \\
\text { (in-house design) }\end{array}$ & $6 / 77$ & 1 & 1 & 5,000 & $\begin{array}{l}\text { Sodium } \\
\text { hydroxide }\end{array}$ & 4.0 & 94 \\
\hline $\begin{array}{l}\text { Kernridge oil Co. } 46 \\
\text { McKittrick, CA } \\
\text { (heater technology) }\end{array}$ & $6 / 78$ & 1 & 1 & 12,000 & $\begin{array}{l}\text { Sodium } \\
\text { hydroxide }\end{array}$ & 1.1 & DNR \\
\hline (Thermotics) & $7 / 78$ & 1 & 1 & 12,000 & $\begin{array}{l}\text { Sodium } \\
\text { hydroxide }\end{array}$ & 1.1 & DNR \\
\hline (C-E Natco) & $1 / 79$ & 1 & 1 & 12,000 & $\begin{array}{l}\text { Sodium } \\
\text { hydroxide }\end{array}$ & 1.1 & DNR \\
\hline \multirow{2}{*}{$\begin{array}{l}\text { Chevron USA, Inc. } \\
\text { Bakersfield, CA } \\
\text { (Koch Engineering) }\end{array}$} & $7 / 78$ & 18 & 3 & $\begin{array}{c}248,000 \\
\text { tota1 }\end{array}$ & $\begin{array}{l}\text { Sodium } \\
\text { carbonate }\end{array}$ & 1.1 & 90 \\
\hline & $7 / 79$ & 12 & 2 & $\begin{array}{c}146,000 \\
\text { total }\end{array}$ & $\begin{array}{l}\text { Sodium } \\
\text { carbonate }\end{array}$ & 1.1 & 90 \\
\hline $\begin{array}{l}\text { Getty Oil Co. } \\
\text { Kern River Field } \\
\text { Bakersfield, CA } \\
\text { (in-house design) }\end{array}$ & $12 / 78$ & 87 & 10 & $\begin{array}{c}891,000 \\
\text { total }\end{array}$ & Soda ash & 1.05 & 96 \\
\hline
\end{tabular}

from the hot water and steam. Gaseous hydrocarbons are emitted along with water vapor, though these too may be collected using carbon absorption. Noncondensible hydrocarbons may also be destroyed using incinerators. Tabak 45 has reported $99 \%$ recovery of condensible well vent hydrocarbons from steamflood operations (without using carbon absorption or incineration). The comparable recovery is $40 \%$ for fireflooding. Despite the high recovery efficiencies for steamflood, it should be noted that well vent HC emissions are still of concern to the state of California, which is now considering regulation to control fugitive emissions of organic compounds from oil (and gas) production operations. 


\begin{tabular}{|c|c|c|c|c|c|c|}
\hline Therma1 EOR Scrub & $\begin{array}{l}\text { EPA } 1979 \\
\text { bbers Plan }\end{array}$ & $\begin{array}{r}\text { Table } \\
\text { Industria1 } \\
\text { hed, Under } \\
\end{array}$ & $\begin{array}{l}5.19 \mathrm{~B} \\
\text { Boiler } \\
\text { Constr } \\
\end{array}$ & $\begin{array}{l}\text { FGD Survey } \\
\text { uction, or }\end{array}$ & $\begin{array}{l}53 \\
\text { Started Up } \\
\end{array}$ & in 1979 \\
\hline $\begin{array}{l}\text { Company name } \\
\text { and location } \\
\text { (Vendor) }\end{array}$ & $\begin{array}{l}\text { Start- } \\
\text { up date }\end{array}$ & $\begin{array}{l}\text { No. of } \\
\text { boilers }\end{array}$ & $\begin{array}{l}\text { No. of } \\
\text { FGD } \\
\text { units }\end{array}$ & $\begin{array}{l}\text { Process } \\
\text { type* }\end{array}$ & $\begin{array}{l}\% \text { sulfur } \\
\text { in crude } \\
\text { oil fuel }\end{array}$ & $\begin{array}{l}\text { Design } \mathrm{SO}_{2} \\
\text { removal } \\
\text { efficiency } \\
(\%)\end{array}$ \\
\hline $\begin{array}{l}\text { Texaco, Inc. } 46 \\
\text { San Ardo, CA } \\
\text { (Ducon Co.) }\end{array}$ & $3 / 79$ & 9 & 3 & $\begin{array}{l}\text { Sodium } \\
\text { carbonate }\end{array}$ & 1.7 & 95 \\
\hline $\begin{array}{l}\text { Mobil oil Co. } 46 \\
\text { Buttonwi11ow, CA } \\
\text { (Heater Technology) }\end{array}$ & $4 / 79$ & 7 & 7 & $\begin{array}{l}\text { Sodium } \\
\text { carbonate }\end{array}$ & 1.1 & 85 \\
\hline $\begin{array}{l}\text { Sun Production Co. } \\
\text { Newha11, CA } \\
\text { (C-E Natco) }\end{array}$ & $9 / 79$ & 1 & 1 & $\begin{array}{l}\text { Sodium } \\
\text { hydroxide }\end{array}$ & 1.2 & 85 \\
\hline $\begin{array}{l}\text { Mobil Oil Co. } \\
\text { McKittrick, CA } \\
\text { (Heater Technology) }\end{array}$ & $\begin{array}{l}\text { Delivered } \\
\quad 8 / 79\end{array}$ & DNR & 20 & $\begin{array}{l}\text { Sodium } \\
\text { hydroxide }\end{array}$ & DNR & DNR \\
\hline $\begin{array}{l}\text { Atlantic Richfield } \\
\text { Ferndale, WA } \\
\text { (FMC Environmental } \\
\text { Equipment) }\end{array}$ & $10 / 79$ & DNR & DNR & $\begin{array}{l}\text { Sodium } \\
\text { (once-thro }\end{array}$ & $\begin{array}{l}\text { DNR } \\
\text { ugh) }\end{array}$ & DNR \\
\hline $\begin{array}{l}\text { Getty Oil Co. } \\
\text { McKittrick, CA } \\
\text { (in-house design) }\end{array}$ & $12 / 79$ & 2 & 2 & $\begin{array}{l}\text { Sodium } \\
\text { hydroxide }\end{array}$ & $1.0-1.1$ & $90-95$ \\
\hline \multirow{3}{*}{$\begin{array}{l}\text { Santa Fe Energy } \\
\text { Taft, CA } \\
\text { (Heater Technology) }\end{array}$} & $12 / 79$ & 8 & 1 & $\begin{array}{l}\text { Dual } \\
\text { alkali }\end{array}$ & 1.1 & 96 \\
\hline & $3 / 80$ & 3 & 3 & \multicolumn{2}{|c|}{$\begin{array}{l}\text { Sodium } 1.1 \\
\text { (once-through) }\end{array}$} & 96 \\
\hline & $7 / 81$ & 1 & 1 & \multicolumn{2}{|c|}{$\begin{array}{l}\text { Sodium } 1.1 \\
\text { (once-through) }\end{array}$} & 96 \\
\hline $\begin{array}{l}\text { Union Oil Co. } \\
\text { McKittrick, CA } \\
\text { (Heater Technology) }\end{array}$ & $\begin{array}{r}1 / 80 \\
3 / 80 \\
6 / 80 \\
7 / 80 \\
11 / 80\end{array}$ & $\begin{array}{l}1 \\
2 \\
2 \\
2 \\
1\end{array}$ & 8 & $\begin{array}{l}\text { Sodium } \\
\text { hydroxide }\end{array}$ & $0.7-1.2$ & 95 \\
\hline $\begin{array}{l}\text { She11 Oil Co. } \\
\text { Coalinga, CA } \\
\text { (Ducon Co.) }\end{array}$ & $\begin{array}{l}3 / 80 \\
7 / 80 \\
6 / 81\end{array}$ & 12 & 3 & $\begin{array}{l}\text { Sodium } \\
\text { hydroxide }\end{array}$ & 0.6 & 90 \\
\hline $\begin{array}{l}\text { Chevron USA, Inc. } \\
\text { Maricopa, CA } \\
\text { (Heater Technology) }\end{array}$ & $\begin{array}{l}\text { Delivered } \\
3 / 80\end{array}$ & DNR & 1 & $\begin{array}{l}\text { Sodium } \\
\text { hydroxide }\end{array}$ & DNR & DNR \\
\hline
\end{tabular}


Table 5.19B continued

\begin{tabular}{|c|c|c|c|c|c|c|}
\hline $\begin{array}{l}\text { Company name } \\
\text { and location } \\
\text { (Vendor) }\end{array}$ & $\begin{array}{l}\text { Start- } \\
\text { up date }\end{array}$ & $\begin{array}{l}\text { No. of } \\
\text { boilers }\end{array}$ & $\begin{array}{l}\text { No. of } \\
\text { FGD } \\
\text { units }\end{array}$ & $\begin{array}{l}\text { Process } \\
\text { type* }\end{array}$ & $\begin{array}{l}\% \text { Sulfur } \\
\text { in crude } \\
\text { oil fuel }\end{array}$ & $\begin{array}{l}\text { Design } \mathrm{SO}_{2} \\
\text { removal } \\
\text { efficiency } \\
(\%)\end{array}$ \\
\hline $\begin{array}{l}\text { Mobil Oil Co. } \\
\text { Taft, CA } \\
\text { (Heater Technology) }\end{array}$ & $\begin{array}{l}\text { Delivered } \\
7 / 80\end{array}$ & DNR & 2 & $\begin{array}{l}\text { Sodium } \\
\text { hydroxide }\end{array}$ & DNR & DNR \\
\hline $\begin{array}{l}\text { Union Oil Co. } \\
\text { McKittrick, Ca } \\
\text { (Anderson 2000) }\end{array}$ & $\begin{array}{r}8 / 80 \\
7 / 81 \\
10 / 81\end{array}$ & $\begin{array}{l}1 \\
2 \\
1\end{array}$ & 4 & $\begin{array}{l}\text { Sodium } \\
\text { hydroxide }\end{array}$ & $0.7-1.2$ & 95 \\
\hline $\begin{array}{l}\text { Texaco, Inc. } \\
\text { Santa Maria, CA } \\
\text { (Thermotics, Inc.) }\end{array}$ & $8 / 80$ & 1 & 1 & $\begin{array}{l}\text { Sodium } \\
\text { hydroxide }\end{array}$ & 3.5 & 98 \\
\hline $\begin{array}{l}\text { Mobil Oil Co. } \\
\text { Bakersfield, CA } \\
\text { (Heater Technology) }\end{array}$ & $\begin{array}{l}\text { Delivered } \\
10 / 80\end{array}$ & DNR & 8 & $\begin{array}{l}\text { Sodium } \\
\text { hydroxide }\end{array}$ & DNR & DNR \\
\hline $\begin{array}{l}\text { Union Oil Co. } \\
\text { McKittrick, CA } \\
\text { (Koch Engineering) }\end{array}$ & $\begin{array}{r}11 / 80 \\
7 / 81 \\
82\end{array}$ & $\begin{array}{l}1 \\
1 \\
2\end{array}$ & 4 & $\begin{array}{l}\text { Sodium } \\
\text { hydroxide }\end{array}$ & $0.7-1.2$ & 95 \\
\hline $\begin{array}{l}\text { Shell oil Co. } \\
\text { Taft, CA } \\
\text { (Neptune Airpol, Inc. }\end{array}$ & $12 / 80$ & 3 & 1 & $\begin{array}{l}\text { Sodium } \\
\text { hydroxide }\end{array}$ & 1.5 & 95 \\
\hline $\begin{array}{l}\text { Chevron USA, Inc. } \\
\text { Bakersfield, CA }\end{array}$ & $0 / 81$ & DNR & 2 & DNR & DNR & DNR \\
\hline $\begin{array}{l}\text { Union Oil Co. } \\
\text { Guadalupe, CA } \\
\text { (Heater Technology) }\end{array}$ & $2 / 81$ & 1 & 1 & $\begin{array}{l}\text { Sodium } \\
\text { hydroxide }\end{array}$ & 2.2 & 95 \\
\hline $\begin{array}{l}\text { Shell Oil Co. } \\
\text { Bakersfield, CA } \\
\text { (Neptune Airpol, Inc. }\end{array}$ & ) & 8 & 1 & $\begin{array}{l}\text { Sodium } \\
\text { hydroxide }\end{array}$ & 1.1 & 95 \\
\hline $\begin{array}{l}\text { Grace Petroleum Corp. } \\
\text { Pismo Beach, CA } \\
\text { (Thermotics, Inc.) }\end{array}$ & - $5 / 81$ & 4 & 4 & $\begin{array}{l}\text { Sodium } \\
\text { hydroxide }\end{array}$ & 1.18 & 98 \\
\hline \multicolumn{7}{|c|}{$\begin{array}{l}\text { *For once-through sodium systems, the makeup sodium alkali is specified } \\
\text { (where known), i.e., sodium hydroxide, sodium carbonate, soda ash, etc. } \\
\text { DNR - Data not reported. }\end{array}$} \\
\hline
\end{tabular}


Carbon Monoxide. Burner maintenance and control appear to be the only feasible methods of controlling carbon monoxide ( $\mathrm{CO}$ ) emissions. The data reported by Tabak 45 and Ryckman 44 indicate that CO levels are too low to be of concern for oil-fired steam generators.

\subsubsection{Regulations and Issues}

A complete evaluation of the effects of air pollution control regulations on EOR production is difficult because of nuances related to both regulations and EOR technologies. The federal Clean Air Act (CAA) is now under review with uncertainties as to which regulations will be amended. New source performance standards (NSPS) are issued by the U.S. Department of Energy for each category of air emission sources. However, through the mechanism of its State Implementation Plan (SIP), a state may assume primary permitting authority, accompanied by surveillance, monitoring, and enforcement authority. State and federal regulations are usually similar, though they need not be: requirements of an SIP must be at least as strict as those at the federal level. In California they are more stringent.

Further complicating matters are EOR technologies themselves. (In this section the discussion is limited to steamflooding and in situ combustion.) Steam generators are individual units (20 to $50 \mathrm{MMBtu} / \mathrm{hr}$ ) which can be manifolded together into multiple stacks. They are designed for mobility and may be moved from one portion of a field to another. They can be operated continuously for fixed periods of time and then shut down. From time to time additional units may be added to (or removed from) an existing group of generators. These latter considerations make application of the "bubble" concept particularly difficult. Under this procedure an emission source is located at the center of a fictitious bubble within which calculations are made of emission and ambient concentrations, which are then compared to standards for use in permitting. With mobile steam generators of the type used in EOR, questions arise as to how to use a bubble: where to center it, where to define its perimeter (e.g., at the field's edge in the event the bubble extends onto another field; at the border of the operator's lease, even if the bubble is still contained within the field, etc.).

National Ambient Air Quality Standards (NAAQS) define maximum acceptable levels of air pollution for several common pollutants, and are established as an integral part of the CAA (see Table 5.20).

The secondary standards are set to protect non-health values, such as vegetation or materials. The Act places the onus on states to develop State Implementation Plans to achieve and maintain acceptable air quality. If the SIP meets certain standards specified in the Act, EPA approves it, and both the state agency and EPA can enforce its terms.

The essential elements of a SIP are (1) emission limits for all types of air pollution sources; (2) permit programs to manage new sources of air pollution; and (3) administrative authorities and resources to monitor air quality, inspect, and test sources for compliance, issue permits, and plan for future air pollution management. 
Table 5.20

National Ambient Air Quality Standards

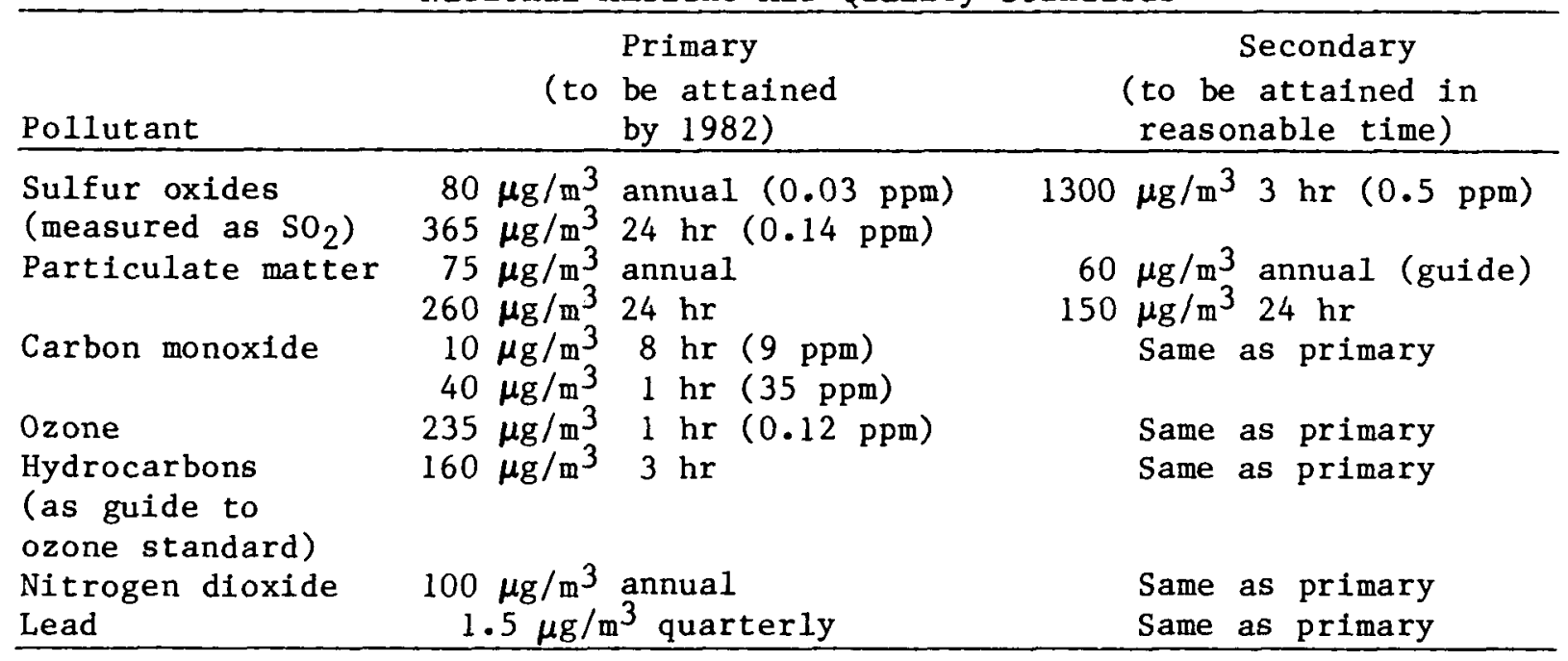

The emission limits are the basic mechanisms through which the state seeks to reduce and control air pollution. Typically, they apply to broad industrial categories (e.g., incinerators; boilers) statewide. A common approach to sulfur oxide pollution is to limit the sulfur content of fuels that may be burned. States with local or regional air quality problems may set spectal limits on emissions or fuel for a region, or even for named sources within a region. California represents an extreme example of the regional approach, with semi-autonomous air pollution control districts directly responsible for most of the program.

Two types of federal standards supplement the SIPs. EPA establishes National Emission Standards for Hazardous Air Pollutants (NESHAPS) and New Source Performance Standards (NSPS). None of the current NESHAPs rules have any bearing on EOR production. 7

NSPS not only relate to new sources of emissions per se, but may also apply when existing stationary sources are modified. In California, for example, a stationary source is defined as

Any building, structure, facility, or installation which emits or may emit any affected pollutant directly or as a fugitive emission.

"Installation" includes any operation, article, machine, equipment or other contrivance which emits or may emit any affected pollutant.

"Building, structure, or facility" includes all pollutant emitting activities, including activities located in California coastal waters adjacent to the district boundaries which: 
Table 5.21

New Source Performance Standards for Fossil-Fuel-Fired Steam Generators of More Than 250-MBtu/hour Heat Input* C.F.R. \$60.40-46

$\begin{array}{ll}\text { Particulate Matter: } & \begin{array}{l}0.10-1 \mathrm{~b} / \mathrm{MBtu} \text { heat input } \\ 20 \% \text { opacity; } 6 \text { minutes/hour, not more than } 27 \%\end{array} \\ \text { Sulfur Dioxide: } & \begin{array}{l}0.80-1 \mathrm{~b} / \mathrm{MBtu} \text { heat input for liquid fuel } \\ 1.2-1 \mathrm{~b} / \mathrm{MBtu} \text { heat input for solid fuel }\end{array} \\ \text { Nitrogen Dioxide: } & 0.20-1 \mathrm{~b} / \mathrm{MBtu} \text { heat input for gaseous fue } 1 \\ & 0.30-1 \mathrm{~b} / \mathrm{MBtu} \text { heat input for liquid fuel } \\ & 0.70-1 \mathrm{~b} / \mathrm{MBtu} \text { heat input for solid fuel (except lignite) }\end{array}$

a. belong to the same industrial grouping, and

b. are located on one or more contiguous or adjacent properties (except for activities located in coastal waters), and

c. are under the same or common ownership, operation, or control or which are owned or operated by entities which are under common control.

Pollutant emitting activities shall be considered as part of the same industrial grouping if:

a. they belong to the same two-digit standard industrial classification code, or

b. they are part of a common production process. (Common production process includes industrial processes, manufacturing processes, and any connected processes involving a common raw materia1.) 55

Furthermore, a11 modifications to existing stationary sources in California are defined in such a way that the modified sources are still regulated according to their emissions. The federal NSPS for fossil-fuelfired steam generators are shown in Table 5.21. However, an emission regulation adopted by the Kern County Air Pollution Control District in November 1980 requires that

...owners or operators of existing generators* to limit emissions of elemental sulfur to 0.11 pound per $10^{6}$ Btu of heat input by July 1, 1984. Emissions of elemental sulfur from new sources must be limited to $0.061 \mathrm{~b}$ per $10^{6} \mathrm{Btu}$ of heat input. This is therefore considerably lower than the NSPS for $\mathrm{SO}_{2}$ emissions from steam

* Steam generators with authorization for construction or permits for operation issued before September 12, 1979. 
boilers promulgated by the U.S. EPA, of $0.80 \mathrm{lb}(0.4 \mathrm{lb}$ sulfur $)$ per $10^{6} \mathrm{Btu}$ of heat input for a stationary steam boiler using a liquid fossil fuel and $1.2 \mathrm{lb}\left(0.6 \mathrm{lb}\right.$ sulfur) per $10^{6} \mathrm{Btu}$ of heat input derived from a solid fossil fuel. Steam generators using heavy oil (332 1b/bb1 and $6.3 \times 10^{6} \mathrm{Btu} / \mathrm{bb} 1$ ) containing $1 \%$ sulfur by weight would require abatement systems with control efficiencies of approximately 80 and $90 \%$, respectively, to meet the emission standards for existing and new sources. 56

Another complication concerns "prevention of serious deterioration" (PSD) review. In areas that attain the NAAQS for one or more of the pollutants emitted by a facility, a PSD review process applies to these particular pollutants. Such a review relates to new or modified sources and affects EOR in both preconstruction and permit phases. At the federal level (as well as state if the particular SIP so indicates), only major sources or modifications to major sources will need PSD permits. For EOR, the U.S. Environmental Protection Agency defines "major" sources as:

Source Category

- Fossil fuel boilers (or combinations) with more than $250 \mathrm{MMBtu} / \mathrm{hr}$ heat input

- Petroleum storage units of more than 300,000 barrels capacity

Al1 others
Emissions After Controls (Any Pollutant)

100 tons per year

If an existing source is already "major," any modification that increases the net emissions of any pollutant requires a PSD permit. Modifications to minor sources only require a permit if the aggregate emissions exceed the values shown above. For example, a modification to a boiler emitting 80 tons per year that will cause a net increase of 40 tons per year will require a permit.

Once a new source or modification is subject to PSD review, that review will include all emissions of any pollutant regulated by the Clean Air Act. As an example, a thermal EOR project with a boiler that will emit more than 100 tons per year of sulfur dioxide will also be subject to review for its emissions of particulate matter, hydrocarbons, hydrogen sulfide, nitorgen dioxide, and any other pollutants. Only emissions of insignificant quantities will be exempt. Table [5.22] shows which pollutants may be subject to review, and what rates of emission are considered significant.

Every new source locating in a PSD area must employ the best avai1able control technology (BACT) for each emission point. The application for a PSD permit must identify the air pollution controls that will be used and demonstrate that those controls represent 
Table 5.22

Guidelines for Significant Emission Rates ${ }^{7}$

\begin{tabular}{lc}
\hline \multicolumn{1}{c}{ Pollutant } & $\begin{array}{c}\text { Emission Rate } \\
\text { (tons }\end{array}$ \\
\hline Carbon monoxide & 100 \\
Nitrogen dioxide & 10 \\
Total suspended particulates & 10 \\
Sulfur dioxide & 10 \\
Ozone & 10 of volatile organic compounds \\
Lead & 1 \\
Mercury* & 0.2 \\
Beryllium* & 0.004 \\
Asbestos* & 1 \\
Fluorides* & 0.02 \\
Sulfuric acid mist* & 1 \\
Vinyl chloride* & 1 \\
Total reduced sulfur & \\
Hydrogen sulfide* & 1 \\
Methyl mercaptan* & 1 \\
Dimethyl sulfide* & 1 \\
Reduced sulfur compounds & \\
$\quad$ Hydrogen sulfide (see above) & \\
Carbon disulfide* & 10 \\
Carbonyl sulfide* & 10 \\
\hline * Noncriteria pollutants. &
\end{tabular}

BACT. BACT review considers the cost of control, so in rare cases no pollution control equipment may be necessary.

If the source will affect a Class I area the applicant will also have to analyze the effect of the emission on the soils, vegetation, visibility, and other such values in the Class I area. (A Class I area is an area where virtually no deterioration of air quality will be allowed to occur. The Clean Air Act designated certain federal lands as "mandatory" Class I areas. Other Class I areas may be established by Indian tribes or state governors. To date, only one such additional area exists: the Northern Cheyenne Indian Reservation in southeastern Montana.) ${ }^{7}$

An interesting twist relates to those places where a new (or modified) source exists and NAAQS are met. In these attainment areas two limits become important: NAAQS and PSD increments. The latter define the total allowable air quallty impact at any one point for any particular pollutant and for all new sources combined. A single new source will not always be allowed the "privilege" of using all the increment by itself.

If the existing afr quality is very near the NAAQS limits, then EPA or the state will analyze the effect to ensure that the 
new source does not cause a violation of the NAAQS. If a non-attainment area is nearby, the EOR operator must also show no contribution to the violations in that area. This can be done by showing that the emissions from the new source do not blow toward the nonattainment area under the wind conditions associated with the violations. Alternatively, the new source can "offset" its contribution to the violation by obtaining a reduction in emissions from another source. 7

Still another complication, perhaps most important to EOR applications in California, is "nonattainment area review." A location is designated as a "nonattainment area" (NA) for a specific pollutant whenever ambient levels for that pollutant (in the given location) exceed NAAQS.* States must devise strategies to correct NA problems, generally as part of (though not as a requirement for) a SIP.

The minimum coverage of federal NA new source review is the same as for PSD review, except that it applies, of course, only to sources locating in NA areas. (Note, however, that state permit requirements usually cover small as well as large sources.) Monitoring will not be required, but modeling and technology review will. The technology review in NA areas is based on a more stringent requirement known as the lowest achievable emission rate (LAER). LAER may require technology transfer of pollution control systems, and gives less weight to cost than does BACT.

The basic requirement for a source locating in a NA area is to show that its construction will not impede programs towards attainment of the standards. The SIP may allow some short-term increases in pollution, but the long-term trend must be downward. Typically, a new source in a NA area will have to "offset" its emissions by getting a nearby existing source to shut down or to reduce its emissions. For example, Volkswagen was allowed to build a plant in Pennsylvania by getting the state to change its highway paving materials to reduce hydrocarbon emissions and "offset" the effect of the new plant. 7

\section{7 .4 Scenario}

Oil-Fired TEOR. Estimated air emissions were calculated on a county-by-county basis using the EOR production scenario described in Section 2.0. Calculated emissions include those from well vents (Section 5.7.1) as we11 as from steam generators. Whenever possible, emission factors have been

*In California, for example, a nonattainment pollutant is considered to be any pollutant for which an ambient air quality standard was exceeded within the air basin more than three discontinuous times (or, for annual standards, more than one time) within the three years immediately preceding the date when the application for the permit to construct was filed, or which has been designated "nonattainment". pursuant to final rulemaking by the Environmental Protection Agency published in the Federal Register as well as any precursers of such pollutants. 
scaled using the average percentage content of sulfur, nitrogen, and ash for oil in particular fields. It should be noted that at some fields associated natural gas is burned instead of produced crude oils, e.g., for some fields in Ventura County, California. Tables 5.23 (uncontrolled emissions) and 5.24 (controlled emissions) report emissions using crude oil as the feedstock in oil field steam generators. In both tables the use of BOLD print indicates that the particular emission is in a nonattainment area and is therefore of special interest for impact of air pollution control regulations. Asterisks indicate the presence of a PSD Class I area within $50 \mathrm{~km}$, clearly another category of regulatory interest (such locations are commonly termed "Class I Impact Areas").

Values of controlled emissions were calculated using lowest achievable emission rates based upon discussions in previous sections, i.e., $95 \%$ reductions in sulfur oxides $\left(\mathrm{SO}_{\mathrm{X}}\right)$ and total suspended particulates (TSP), $60 \%$ reductions in oxides of nitrogen $\left(\mathrm{NO}_{\mathrm{x}}\right)$, and $95 \%$ reduction in hydrocarbons (HC). California air pollution regulations were chosen for purposes of worst case analyses. Several caveats accompany use of these scenario projected emissions :

(1) EOR activities are presented by field in areas where several operators may have one or more sets of steam generators. Both uncontrolled and controlled emissions are similarly presented by field.

(2) Details such as the number of major sources within a given field are precluded. For regulatory purposes, a "major stationary source" is taken as one "which emits daily 200 pounds or more of an air contaminant for which there is a NAAQS or any precursor of such contaminant." (Kern County New Source Review Rules, Rule 210.1.1.I, September 1979.) This level is equivalent to 36.5 tons per year.

(3) The scenario does not specify which particular fields in a nonattainment area would require offsets. Clearly the aggregate of Kern County fields, for example, indicates that some (or all) fields will require offsets.

(4) Emissions are yearly averages over a 40-year time span. It is clear that fields may (and probably will) be developed at different rates, thus changing yearly averaged emissions.

Table 5.24 indicates that most steamflood projects in the scenario fall under the "major stationary source" rubric, and, for California counties, are genera11y in nonattainment areas for $\mathrm{TSP}$ and $\mathrm{SO}_{\mathrm{x}}$. Even with strict control technologies, most California EOR operators will require offsets before projects can achieve their maximum average yearly production estimates. This statement holds true even for those fields in attainment areas (e.g., $\mathrm{NO}_{\mathrm{x}}$ in the Kern County, Californfa, S. Belridge field). Because of the heavy concentration of thermal EOR in Kern County, several EOR operators not classified as major sources find themselves in the unenviable position of still requiring offsets. A good example is the Jasmin field, where TSP and 
Table 5.23

Air Emissions From ECR Environmental Scenario (Steamflood Fields)

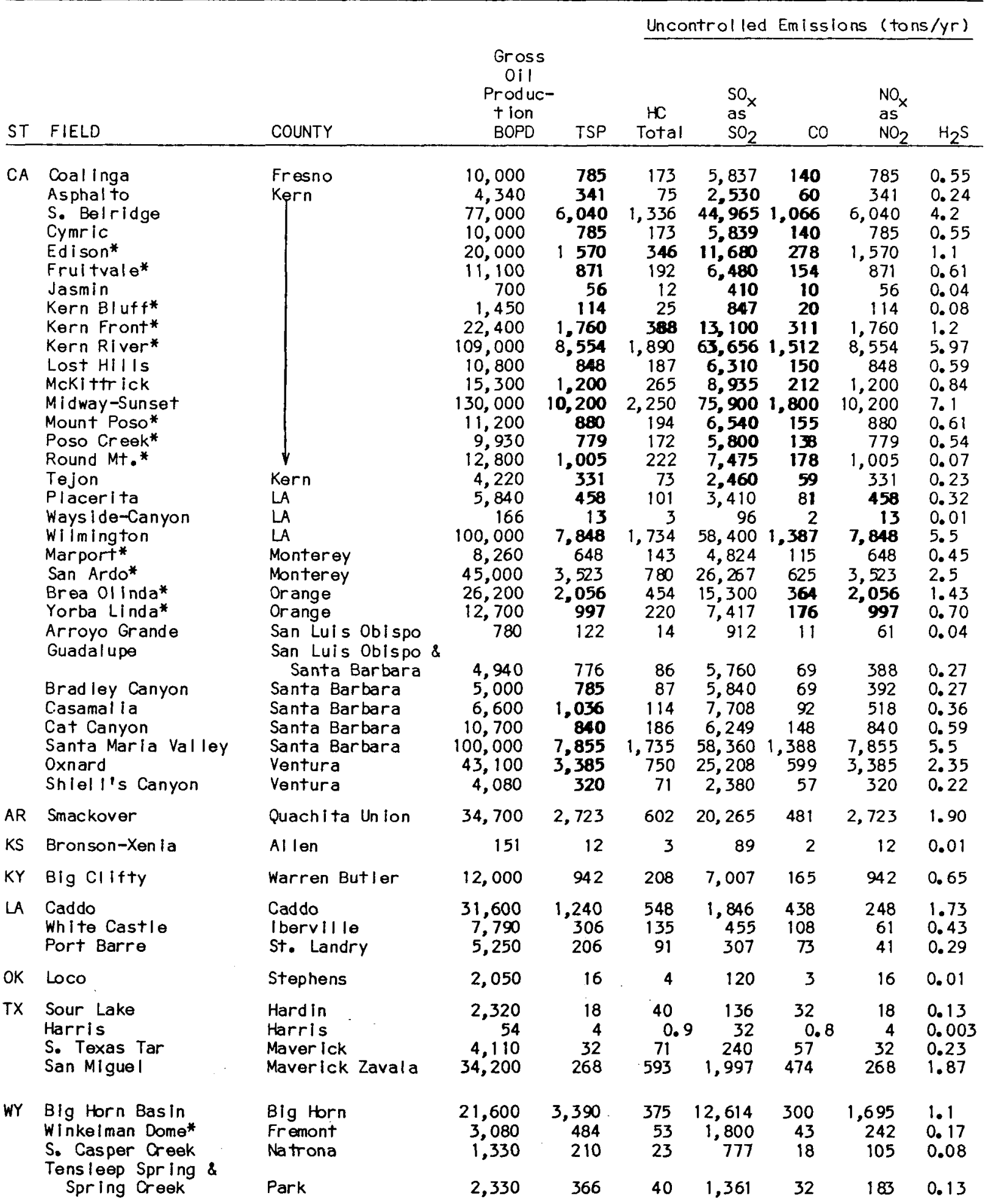


Table 5.23 continued

Uncontrolled Emissions (tons/yr)

\begin{tabular}{|c|c|c|c|c|c|c|c|c|c|}
\hline ST & FIELD & COUNTY & $\begin{array}{c}\text { Gross } \\
\text { oil } \\
\text { Produc- } \\
\text { tion } \\
\text { BOPD } \\
\end{array}$ & TSP & $\begin{array}{c}\mathrm{HC} \\
\text { Total }\end{array}$ & $\begin{array}{l}\mathrm{SO}_{x} \\
\mathrm{as}_{2} \\
\mathrm{SO}_{2} \\
\end{array}$ & $\infty$ & $\begin{array}{l}\mathrm{NO}_{x} \\
\text { as } \\
\mathrm{NO}_{2}\end{array}$ & $\mathrm{H}_{2} \mathrm{~S}$ \\
\hline $\mathrm{CA}$ & $\begin{array}{l}\text { Lynch Canyon* } \\
\text { Paris Val ley* } \\
\text { Newport-Banning }\end{array}$ & $\begin{array}{l}\text { Monterey } \\
\text { Monterey } \\
\text { Orange }\end{array}$ & $\begin{array}{l}2,890 \\
1,130 \\
9,110\end{array}$ & $\begin{array}{r}79 \\
31 \\
249\end{array}$ & $\begin{array}{r}210 \\
83 \\
665\end{array}$ & $\begin{array}{r}16 \\
6 \\
50\end{array}$ & $\begin{array}{r}5 \\
2 \\
15\end{array}$ & $\begin{array}{l}26 \\
10 \\
83\end{array}$ & $\begin{array}{r}16 \\
6.18 \\
49.88\end{array}$ \\
\hline $\mathrm{CO}$ & Plum Bush & Washington & 4,130 & 113 & 299 & 23 & 7 & 38 & 22.6 \\
\hline LA & Bel levue & Bossier & 2,310 & 63 & 169 & 1.3 & 4 & 2 & 12.65 \\
\hline MS & W. He idel berg & Jasper & 4,840 & 66 & 353 & 14 & 8 & 4 & 26.5 \\
\hline$M$ & Lower Hos pah & Mckinley & 1,810 & 49 & 132 & 10 & 3 & 17 & 9.9 \\
\hline SD & Buffalo & Hard Ing & 972 & 27 & 71 & 5 & 2 & 9 & 5.3 \\
\hline$T X$ & $\begin{array}{l}\text { Slocum } \\
\text { Saratoga } \\
\text { Rainbow Bend } \\
\text { Holt }\end{array}$ & $\begin{array}{l}\text { Anderson } \\
\text { Hard in } \\
\text { LaSal le } \\
\text { Montague }\end{array}$ & $\begin{array}{l}2,000 \\
3,700 \\
2,610 \\
5,000\end{array}$ & $\begin{array}{r}5 \\
10 \\
7 \\
14\end{array}$ & $\begin{array}{l}146 \\
270 \\
191 \\
365\end{array}$ & $\begin{array}{l}11 \\
20 \\
14 \\
27\end{array}$ & $\begin{array}{l}3 \\
6 \\
4 \\
8\end{array}$ & $\begin{array}{l}2 \\
3 \\
3 \\
5\end{array}$ & $\begin{array}{l}11 \\
20.26 \\
14.3 \\
27.1\end{array}$ \\
\hline
\end{tabular}

*PSD Class 1 area within $50 \mathrm{~km}$.

$\mathrm{SO}_{\mathrm{x}}$ emissions are smal1 ( 3 and 21 tons/yr, or 0.7 and $4.8 \mathrm{lb} / \mathrm{hr}$ respective1y). Table 5.25 (from ref. 57) allows a calculation of worst case estimates of point source air quality impacts. The effective stack height is defined as the height of the proposed stack plus the expected plume rise. Consider a 20-meter stack with a 20-meter plume rise. At 200 to 400 meters downwind, the maximum 24-hour concentration of TSP would be $3 \mu \mathrm{g} / \mathrm{m}^{3}$, and $19 \mu \mathrm{g} / \mathrm{m}^{3}$ for $\mathrm{SO}_{\mathrm{x}}$. Without contributions from other sources and assuming little or no background for either component, these concentrations are $1 \%$ and $5 \%$, respectively, of corresponding NAAQS. Unfortunately, the emissions of all other Kern County EOR operations will boost background concentrations considerably. Depending upon when the Jasmin field operators apply for air emission permits, it is likely they will require offsets before starting their projects: avallable offsets will probably be scarce. It is also noted that 14 California steamflood and in situ fields are in PSD Class I impact areas. Oil from these operations amounts to $2 \%$ of total California EOR production; because of their location, it is possible that clean air regulations will limit or preclude much of their development.

Steamflooding in other regions of the U.S. will also be affected by Clean Air Act and SIP regulations. All of these fields are presently in attainment areas. It is clear from Table 5.26 that only the Smackover field (Arkansas) may require offsets. Fireflood (i.e., in situ) operations at non-California fields will not be affected by CAA regulations.

Coal-Fired TEOR. Previous discussions have alluded to the use of coal instead of lease-crude to fire TEOR steam generators. This would add a minimum of $33 \%$ more incremental tertiary thermal oil to the marketplace. Table 5.27 presents estimates of uncontrolled air emissions for such a case. Using the previously defined scenario, a calculation was first made of the amount of coal required at each field. The type of coal which might be used in each state was estimated on the basis of DOE data on coal transhipment (see Table 5.28). Table 5.29 presents results of applying technologies to 
Table 5.24

Controlled Emissions From Steamflood Fields for Environmental Scenario

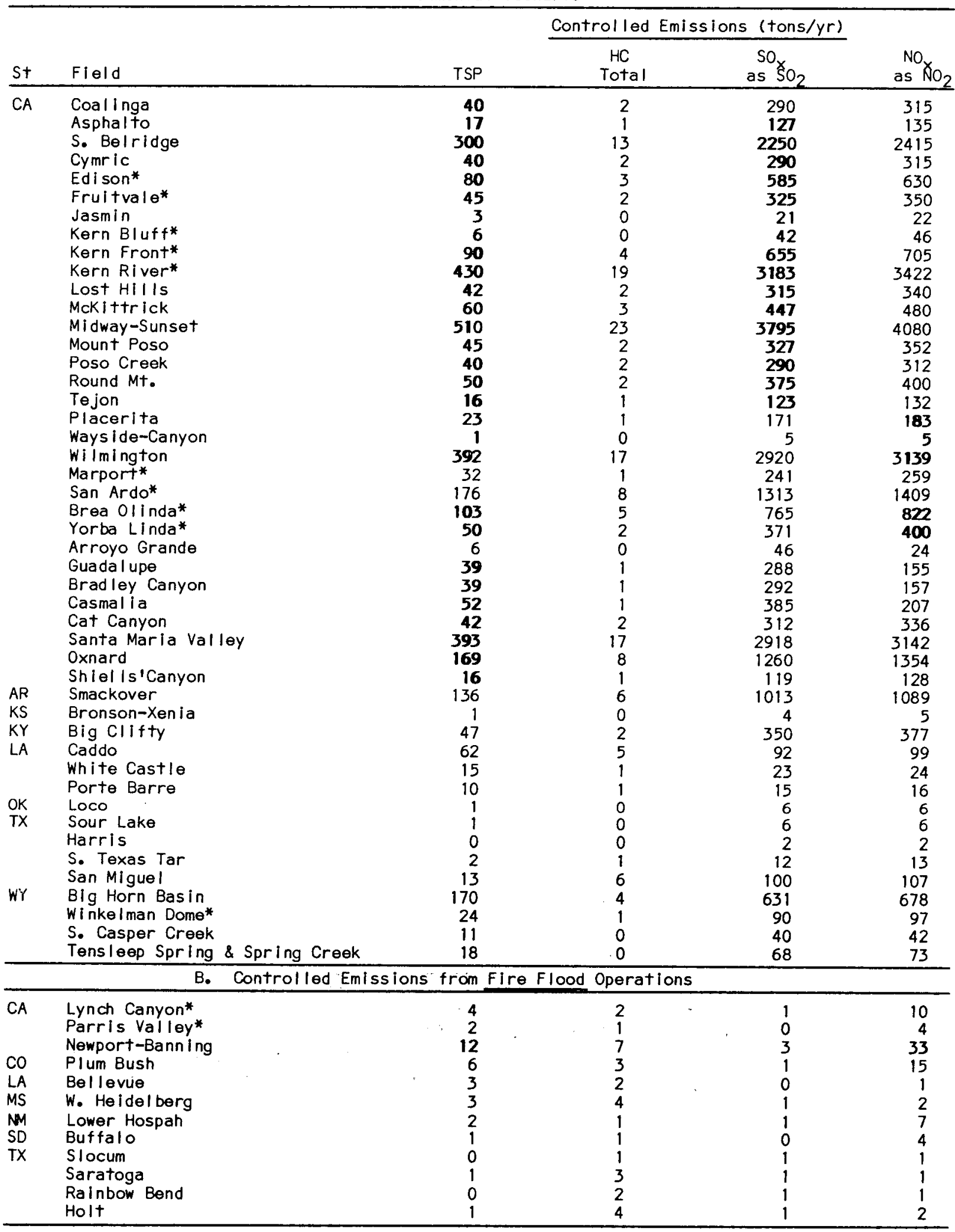

*PSD Class 1 area with $50 \mathrm{~km}$. 
Table 5.25

Worst Case Estimates of Point Source Air Quality Impacts 57

\begin{tabular}{|c|c|c|c|c|c|c|c|}
\hline \multirow{3}{*}{$\begin{array}{c}\text { Stack } \\
\text { Height/ } \\
(\mathrm{m})\end{array}$} & \multirow{3}{*}{$\begin{array}{c}\text { Downwind dis- } \\
\text { tances to maxi- } \\
\text { mum estimated } \\
\text { concentration } \\
(\mathrm{m})\end{array}$} & \multicolumn{6}{|c|}{ Estimated Maximum One-Hour Concentrations $\left(\mu \mathrm{g} / \mathrm{m}^{3}\right)$} \\
\hline & & \multicolumn{6}{|c|}{ Source Strength } \\
\hline & & $\begin{array}{c}5 \\
1 \mathrm{~b} / \mathrm{hr}\end{array}$ & $\begin{array}{c}10 \\
1 \mathrm{~b} / \mathrm{hr}\end{array}$ & $\begin{array}{c}20 \\
1 \mathrm{~b} / \mathrm{hr}\end{array}$ & $\begin{array}{c}40 \\
1 \mathrm{~b} / \mathrm{hr}\end{array}$ & $\begin{array}{c}80 \\
1 \mathrm{~b} / \mathrm{hr} \\
\end{array}$ & $\begin{array}{c}120 \\
1 \mathrm{~b} / \mathrm{hr}\end{array}$ \\
\hline 5 & $<100$ & 3150 & 6300 & 12800 & 25200 & 50400 & 75700 \\
\hline 10 & 100 & 945 & 1890 & 3840 & 7560 & 15120 & 22700 \\
\hline 15 & 150 & 380 & 760 & 1530 & 3020 & 6040 & 9080 \\
\hline 20 & 200 & 220 & 440 & 900 & 1760 & 3530 & 5300 \\
\hline 30 & 300 & 90 & 190 & 380 & 760 & 1510 & 2270 \\
\hline 40 & $200-400$ & 50 & 110 & 220 & 430 & 870 & 1300 \\
\hline 50 & $250-450$ & 40 & 70 & 150 & 290 & 580 & 880 \\
\hline 70 & 350 & 20 & 40 & 80 & 170 & 330 & 500 \\
\hline 100 & 450 & 10 & 20 & 40 & 90 & 190 & 290 \\
\hline
\end{tabular}

Note: The wind speed was assumed to be $1 \mathrm{~m} / \mathrm{s}$. The effective plume height was equal to the physical stack height.

Table 5.26

Estimated Maximum 24-Hour Concentrations ${ }^{2}\left(\mu \mathrm{g} / \mathrm{m}^{3}\right)$ at Distance 200-400 m From Controlled Emissions (see Table 5.21)

Non-California TEOR

Fields Classifiable as Major Emitters 1

Location

Smackover (County, State)

Big Clifty

Caddo

San Migue1

Big Horn Basin

Winkelman Dome ${ }^{3}$

S. Casper Creek

Tensleep Spring \&

\begin{tabular}{ccrrr} 
Spring Creek & Park, WY & 5 & 25 & 30 \\
\hline NAAQS $(24-\mathrm{hr}$ av $)$ & & 260 & 365 &
\end{tabular}

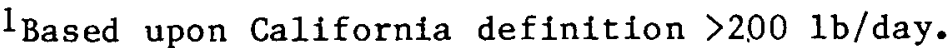

2 Assumes 40-m effective stack height; uses estimates of Table 5.24. These values are added to background (i.e., existing) concentrations (see ref. 58).

3 PSD Class I area within $50 \mathrm{~km}$. 
Table 5.27

Uncontrol led Air Emissions From EOR Environmental Scenario Using Coal to Generate Steam

\begin{tabular}{|c|c|c|c|c|c|c|c|c|c|}
\hline \multirow[b]{2}{*}{ Field } & \multirow[b]{2}{*}{ Cty } & \multirow{2}{*}{$\begin{array}{l}\text { Gross } \\
\text { Oil } \\
\text { Produc- } \\
\text { tion } \\
\text { BOPD } \\
\end{array}$} & \multirow[b]{2}{*}{$\begin{array}{c}\text { Btu Oil } \\
\text { Burned/ } \\
\text { Day }\end{array}$} & \multirow[b]{2}{*}{$\begin{array}{c}\text { Equiv. } \\
\text { Coal } \\
\text { tons/ } \\
\text { day } \\
\end{array}$} & \multicolumn{5}{|c|}{ Tons/Year } \\
\hline & & & & & TSP & НСTOT & $\begin{array}{l}\mathrm{SO}_{x} \\
\text { as } \\
\mathrm{SO}_{2} \\
\end{array}$ & $\infty$ & $\mathrm{NO}_{x}$ \\
\hline AR Smackover & Quachita & 34700 & $6.71 \times 10^{10}$ & 4792 & 52035 & 875 & 10495 & 1749 & 5247 \\
\hline $\begin{array}{l}\text { CA Coal inga } \\
\text { Asphal to } \\
\text { S. Belridge } \\
\text { Cymric } \\
\text { Edison* } \\
\text { Fruitvale* } \\
\text { Jasmin } \\
\text { Kern Bluff* } \\
\text { Kern Front* } \\
\text { Kern River* } \\
\text { Lost Hills } \\
\text { Mokittrick } \\
\text { Midway-Sunset } \\
\text { Mount Poso* } \\
\text { Poso Creek* } \\
\text { Round Mt.* } \\
\text { Tejon } \\
\text { Placerita } \\
\text { Wayside-Canyon } \\
\text { Wilmington } \\
\text { Marport* } \\
\text { San Ardo* } \\
\text { Brea Ol inda* } \\
\text { Yorba Linda* } \\
\text { Arroyo Grande } \\
\text { Guadalupe } \\
\text { Bradley Canyon } \\
\text { Casmal ia } \\
\text { Cat Canyon } \\
\text { Santa Maria Val ley } \\
\text { Oxnard } \\
\text { Shiel Is' Canyon }\end{array}$ & $\begin{array}{l}\downarrow \\
\text { Kern } \\
\text { L.A. } \\
\text { L.A. } \\
\text { L.A. } \\
\text { Monterey } \\
\text { Monterey } \\
\text { Orange } \\
\text { Orange } \\
\text { S.L.O. } \\
\text { S.L.0.\&S.B. } \\
\text { S.B. } \\
\text { S.B. } \\
\text { S.B. } \\
\text { S.B. } \\
\text { Vengura } \\
\text { Ventura }\end{array}$ & $\begin{array}{r}10000 \\
4340 \\
77000 \\
10000 \\
20000 \\
11100 \\
700 \\
1450 \\
22400 \\
109000 \\
10800 \\
15300 \\
130000 \\
11200 \\
9330 \\
12800 \\
4220 \\
5840 \\
166 \\
100000 \\
8260 \\
45000 \\
26200 \\
12700 \\
780 \\
4940 \\
5000 \\
6600 \\
10700 \\
100000 \\
43100 \\
4080\end{array}$ & $\begin{array}{l}1.93 \times 10^{10} \\
8.39 \times 10^{9} \\
1.49 \times 10^{11} \\
1.93 \times 10^{10} \\
3.87 \times 10^{10} \\
2.15 \times 10^{10} \\
1.35 \times 10^{9} \\
2.8 \times 10^{9} \\
4.33 \times 10^{10} \\
2 \times 11 \times 10^{11} \\
2.09 \times 10^{10} \\
2.96 \times 10^{10} \\
2.5 \times 10^{11} \\
2.17 \times 10^{10} \\
1.92 \times 10^{10} \\
2.47 \times 10^{10} \\
8.16 \times 10^{9} \\
1.13 \times 10^{10} \\
3.21 \times 10^{9} \\
1.93 \times 10^{11} \\
1.6 \times 10^{10} \\
8.69 \times 10^{10} \\
5.07 \times 10^{10} \\
2.46 \times 10^{10} \\
1.51 \times 10^{9} \\
9.55 \times 10^{9} \\
9.67 \times 10^{9} \\
1.28 \times 10^{10} \\
2.07 \times 10^{10} \\
1.93 \times 10^{11} \\
8.33 \times 10^{10} \\
7.89 \times 10^{9}\end{array}$ & $\begin{array}{c}1137 \\
494 \\
8760 \\
1137 \\
2275 \\
1262 \\
80 \\
165 \\
2547 \\
12400 \\
1228 \\
1740 \\
1.48 \times 10^{4} \\
1275 \\
1130 \\
1455 \\
480 \\
665 \\
19 \\
1.136 \times 10^{4} \\
940 \\
5117 \\
2980 \\
1444 \\
89 \\
562 \\
568 \\
750 \\
1217 \\
11372 \\
4900 \\
464\end{array}$ & $\begin{array}{r}8305 \\
3608 \\
673975 \\
8305 \\
16615 \\
9217 \\
583 \\
1205 \\
18602 \\
90565 \\
8970 \\
12708 \\
108094 \\
9312 \\
8253 \\
10627 \\
3506 \\
4857 \\
140 \\
83008 \\
6865 \\
37372 \\
21765 \\
10546 \\
650 \\
4105 \\
4148 \\
5478 \\
8889 \\
83060 \\
35793 \\
3389\end{array}$ & $\begin{array}{r}208 \\
90 \\
1599 \\
208 \\
415 \\
230 \\
15 \\
30 \\
465 \\
2263 \\
224 \\
318 \\
2701 \\
233 \\
206 \\
265 \\
88 \\
121 \\
3 . \\
2074 \\
172 \\
935 \\
544 \\
264 \\
16 \\
103 \\
104 \\
137 \\
207 \\
207 \\
890\end{array}$ & $\begin{array}{r}4387 \\
1906 \\
33796 \\
4387 \\
8777 \\
4869 \\
308 \\
637 \\
9826 \\
47840 \\
4738 \\
6713 \\
57100 \\
4919 \\
4360 \\
5613 \\
1852 \\
2566 \\
74 \\
43848 \\
3627 \\
19741 \\
11497 \\
5571 \\
343 \\
2168 \\
2191 \\
2894 \\
4695 \\
43874 \\
18905 \\
1790\end{array}$ & $\begin{array}{r}415 \\
180 \\
3199 \\
415 \\
830 \\
461 \\
29 \\
60 \\
930 \\
4526 \\
448 \\
635 \\
5402 \\
465 \\
412 \\
531 \\
175 \\
243 \\
7 \\
4148 \\
343 \\
1867 \\
1088 \\
527 \\
32 \\
205 \\
207 \\
274 \\
444 \\
4151 \\
1789 \\
169\end{array}$ & $\begin{array}{r}2075 \\
900 \\
16000 \\
2075 \\
4152 \\
2300 \\
146 \\
300 \\
4648 \\
22600 \\
2240 \\
3176 \\
27000 \\
2300 \\
2060 \\
2655 \\
876 \\
1200 \\
35 \\
20700 \\
1700 \\
9340 \\
5440 \\
2640 \\
160 \\
1026 \\
1036 \\
1370 \\
2220 \\
20750 \\
8940 \\
850\end{array}$ \\
\hline KS Bronson-Xenia & Allen & 151 & $2.92 \times 10^{8}$ & 14.2 & 711 & 2.7 & 391 & 5.3 & 39 \\
\hline KY Big Clifty & $\begin{array}{l}\text { Warren } \\
\text { Butler }\end{array}$ & 1200 & $2.32 \times 10^{10}$ & 967 & 13766 & 175 & 16765 & 351 & 2648 \\
\hline $\begin{array}{l}\text { LA Caddo } \\
\text { White Castle } \\
\text { Porte Barre } \\
\text { OK Loco } \\
\text { TX Sour Lake } \\
\text { Harris } \\
\text { S. Texas Tar } \\
\text { San Miguel }\end{array}$ & $\begin{array}{l}\text { Caddo } \\
\text { Ibervil le } \\
\text { St. Landry } \\
\text { Stephens } \\
\text { Harden } \\
\text { Harris } \\
\text { Maverick } \\
\text { Maverick \& } \\
\text { Zavala }\end{array}$ & $\begin{array}{c}31600 \\
7790 \\
5250 \\
2050 \\
2320 \\
54.2 \\
4110 \\
\\
34200\end{array}$ & $\begin{array}{l}6.11 \times 10^{10} \\
1.51 \times 10^{10} \\
1.02 \times 10^{10} \\
3.96 \times 10^{9} \\
4.49 \times 10^{9} \\
1.05 \times 10^{8} \\
7.95 \times 10^{9} \\
6.61 \times 10^{10}\end{array}$ & $\begin{array}{c}4364 \\
1076 \\
725 \\
165 \\
340 \\
7.9 \\
602\end{array}$ & $\begin{array}{r}47385 \\
11685 \\
7872 \\
4306 \\
5212 \\
121 \\
9230\end{array}$ & $\begin{array}{l}796 \\
196 \\
132 \\
30 \\
62 \\
1.4 \\
110\end{array}$ & $\begin{array}{r}9557 \\
2357 \\
1588 \\
3318 \\
1303 \\
30 \\
2307\end{array}$ & $\begin{array}{c}1593 \\
393 \\
265 \\
60 \\
124 \\
2.9 \\
220\end{array}$ & $\begin{array}{c}4780 \\
1180 \\
794 \\
450 \\
372 \\
8.7 \\
660\end{array}$ \\
\hline $\begin{array}{l}\text { Wy Big Horn Basin } \\
\text { Winkelman Dome* } \\
\text { S. Casper Creek } \\
\text { Tens leep-Spring }\end{array}$ & $\begin{array}{l}\text { Zavala } \\
\text { Big Horn } \\
\text { Fremont } \\
\text { Natrona }\end{array}$ & $\begin{array}{r}34200 \\
21600 \\
3080 \\
1330\end{array}$ & $\begin{array}{l}6.61 \times 10^{10} \\
4.18 \times 10^{10} \\
5.95 \times 10^{9} \\
2.57 \times 10^{9}\end{array}$ & $\begin{array}{r}5010 \\
2400 \\
342 \\
148\end{array}$ & $\begin{array}{r}76800 \\
18738 \\
2670 \\
1155\end{array}$ & $\begin{array}{r}914 \\
438 \\
62 \\
27\end{array}$ & $\begin{array}{r}19200 \\
6614 \\
942 \\
408\end{array}$ & $\begin{array}{r}1829 \\
876 \\
125 \\
54\end{array}$ & $\begin{array}{r}5490 \\
4380 \\
620 \\
270\end{array}$ \\
\hline \& Spring Creek & Park & 2330 & $4.5 \times 10^{9}$ & 259 & 2022 & 47 & 714 & 95 & 470 \\
\hline
\end{tabular}


Table 5.28

Types of Coal Which Might Be Used in Place of Oil for Scenario TEOR

\begin{tabular}{|c|c|c|c|c|c|c|c|}
\hline $\begin{array}{c}\text { Destina- } \\
\text { tion } \\
\text { State }\end{array}$ & $\begin{array}{l}\text { Potential } \\
\text { Source } \\
\text { of Coal } \\
\text { (State) }\end{array}$ & Type* & $\mathrm{x}$ & $\begin{array}{l}\text { Heating } \\
\text { Value } \\
10^{3} \text { Btu/1b }\end{array}$ & $\begin{array}{l}\text { Sulfur } \\
(\% \text { wt })\end{array}$ & $\begin{array}{c}\text { Ash } \\
(\% \text { wt })\end{array}$ & $\begin{array}{l}\text { Cost } \\
\text { (\$/ton) }\end{array}$ \\
\hline $\mathrm{CA}$ & MT & S & & 8.5 & 0.7 & 8.7 & 17 \\
\hline $\mathrm{AR}$ & $\mathrm{AR}$ & L & & 7 & 0.4 & 8.5 & \\
\hline $\mathrm{KS}$ & $\mathrm{KS}$ & B & & 10 & 4.0 & 21 & \\
\hline KY & KY & B & & 12 & 2.5 & 6 & \\
\hline LA & AR & L & & 7 & 0.4 & 8.5 & \\
\hline OK & $\mathrm{OK}$ & B & & 12 & 2.9 & 11 & 33 \\
\hline $\mathrm{TX}$ & $\mathrm{TX}$ & $\mathrm{L}$ & & 6.6 & 0.7 & 12 & 8 \\
\hline WY & WY & $\mathrm{S}$ & & 8.7 & 0.5 & 9.3 & 8 \\
\hline
\end{tabular}

* Key: $\quad B=$ Bituminous

$\mathrm{S}=$ Subbituminous

$\mathrm{L}=$ Lignite

Average sulfur and ash content has been computed for the coals listed above.

\begin{tabular}{lcc} 
Bituminous & Average $\%$ Sulfur & Average \% Ash \\
\cline { 2 - 3 } & 3.1 & 12.7 \\
Subbituminous & 0.6 & 9 \\
Lignite & 0.55 & 10 \\
\hline
\end{tabular}

contro1 TSP and $\mathrm{SO}_{\mathrm{x}}$ ( $95 \%$ reduction), $\mathrm{NO}_{\mathrm{x}}$ ( $60 \%$ reduction), and hydrocarbons ( $99 \%$ reduction). Comparison with Table 5.24 shows controlled emissions of TSP to be significantly greater if coal is used rather than oil (in some cases by two orders of magnitude). $\mathrm{SO}_{\mathbf{x}}$ and $\mathrm{NO}_{\mathbf{x}}$ emissions from coal would be less in California, Arkansas, and Wyoming, and greater in Kansas, Kentucky, Louisiana, Oklahoma, and Texas, the former group of states probably using subbituminous and lignite. From an environmental perspective, the use of oil as a feedstock for TEOR steam generators is clearly preferable to the use of coal.

\subsubsection{Conclusions}

Future TEOR production will be constrained in California where clean air regulations are stricter than in any other state or at the federal level. offsets will be required to produce as much tertiary ofl in California as can be expected during the next generation. TEOR production at other fields does not appear to be affected significantly by air control regulations. While the use of coal as feedstock to steam generators has attracted the attention of both oil industry and federal agencies, controlled emissions will generally cause more problems than if lease crude is used as fuel.

TEOR presents nuances which make application of afr pollution control regulations somewhat difficult. Steam generators are usually manifolded together into a common stack. Individual (and ganged) units are used at different parts of the same (or different) fields by the same operator at 


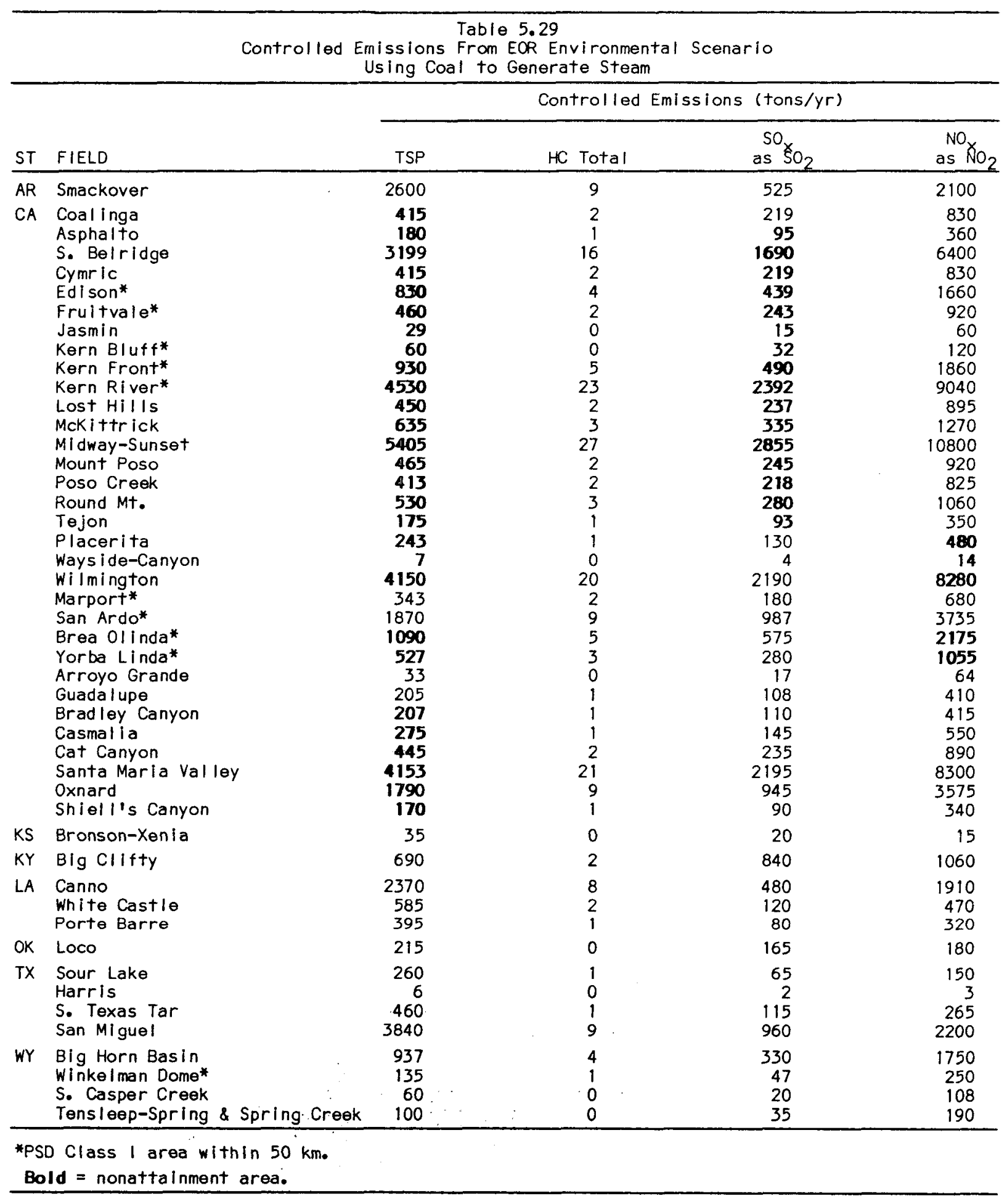


different times. Complications will arise in applyint the bubble concept to such cases: centering the bubble, how the bubble moves with the source, where the outer limits of the bubble will extend...these and other considerations must be established before conclusive analyses can be made of the effects of the CAA and SIP's on TEOR production.

Congressional actions which may result in amendments to the CAA are under study and will doubtless add to the present confusion, where air quality regulations may differ from one district to another within the same state.

\subsection{SOLID WASTE IMPACTS}

Solid wastes from EOR come from drilling, air pollution control technologies, and water treatment. This section reviews these categories, characterizes the solid wastes from each, estimates volumes, and evaluates disposal options in terms of existing environmental regulations. (The reader should also refer to Section 5.6 .4 for an additional discussion of EOR chemicals.)

\subsubsection{Sources of Wastes}

Tertiary recovery usually begins with the recompletion of marginally producing oil wells which are then used for injection of driving fluids. New injection wells are also usually required. However, drilling wastes and muds resulting from these activities will be identical to those from current primary and secondary operations. Thus the solid waste impact from EOR drilling will depend on the footage of new or recompleted wells, the manner in which solids are handled and disposed of, and the extent to which applicable environmental regulations are monitored and enforced.

Solid wastes from air pollution control devices and from water treatment (e.g., for steam generators and chemical flooding) represent new (i.e., EORspecific) categories of oil production wastes. The characteristics and amounts of solid wastes from water treatment may change in the future as techniques are developed to utilize more produced waters in chemical flooding. These poorer-quality waters will be used with chloride-resistant polymers expected to be available in the future, thereby reducing demands for freshwaters. It is expected that the chemical characteristics of these wastes will be simflar to those encountered in other industries; only the quantities of solid wastes will be different.

011 field steam generators have traditionally been fired using crude oil. Only recently have operators serfously considered the widespread use of coal. Resulting solid wastes will then be identical to those already encountered in other coal-fired industrial and utility burners.

Drilling Wastes. These wastes derive from fluids (i.e., muds) used in drilling, per se, as well as from materials brought to the surface by the fluids themselves (e.g., sand and crushed rocks, referred to as cuttings). In addition to transporting cuttings to the surface, drilling muds are used to control formation pressures, to clean the hole ahead of the drill bit, to stabilize the hole, and to both lubricate and cool the drill bit. Cuttings 
are separated from mud and are either disposed of in pits or used for other purposes (e.g., as on-site roadbed materials).

Drilling muds are reused as often as practicable. Significant research has gone into their physical and chemical compounding. Nevertheless their formulation approaches an art form, involving additions of diverse materials to perform the many functions previously mentioned. A drilling fluid is a liquid base (either water or oil, commonly the former) which carries suspending and weighting agents. Other materials are added to control pH, emulsion stability, alkalinity, flow properties, etc. Water-based mud commonly contains bentonite to help transport cuttings, as well as lignite, lignosulfonates, and polymers to control filtration, that is, the tendency of a drilling fluid to interact with and plug a producing formation. Barite, i.e., barium sulfate, is commonly used as a weighting material. Table 5.30 shows compositions of various commercial-grade barites. The compositions of typical water, polymer, and oil muds are shown in Table 5.31.

Water and polymer muds are usually formulated and reconditioned at the rig using materials shipped in bags or drums. Oil muds, on the other hand, are usually formulated off site, transported to the rig for use, and shipped back to the formulation plant for reconditioning (and/or storage).

After their useful lives are over (mud compounds are of ten expensive and are therefore reconditioned and reused), drilling muds are commonly placed in pits together with discarded cuttings. Unlined pits were common in the past. After drying over a period of time the pits were either covered with overburden or their contents spread onto land surfaces and disked into the soi1. (Often wet muds were pumped onto fields and plowed under when dried.) These practices have led to widespread instances of contamination of shallow freshwater aquifers and are legally no longer acceptable. (The reader is referred to Section 5.6 for a more detailed accounting of aquifer contamination). Current state regulations now bar unlined pits and require instead the use of impermeable liners, such as clay or plastics.

The composition of cuttings, drilling fluids, and components is site specific and depends upon formation characteristics and the specific drilling practices employed. Quantities of fluids used for drilling wells at the Naval Reserves E1k Hill Field is estimated at 50 to 100 barrels per thousand feet of well depth. 60 When used fluids are combined with cuttings, rig deck waste waters, etc., total volumes of materials requiring storage may amount to 5000 to 50,000 bbi at any given location.

Many other materials have been added to drilling fluids in addition to those mentioned previously. Some of these substances are shown in Table 5.32. The extent to which solid wastes, attributable to drilling fluids, might constrain EOR production depends upon three questions: whether any materials in the waste are hazardous or toxic, whether laws exist to regulate their handilng and disposal, and whether approved sites have sufficient capacity to accept these materials.

The handling and treating of drilling muds involves a sequence of operations which separate unwanted solids, gases, and liquids using specialized equipment. Discharged materials are stored in either holding tanks or 
Table 5.30

Compositional Analysis of Drilling Mud Grade Barite (Barlum Sulfate), Calclte (Calclum Carbonate) and Siderite (Iron Carbonate) 58

\begin{tabular}{|c|c|c|c|}
\hline Propertles & Barite & Cal cite & Si derite \\
\hline $\begin{array}{l}\text { Specific gravity } \\
\text { Main constituent (see column heading) } \\
\text { pH } \\
\text { Fish toxicity* } \\
\text { Application in humans }\end{array}$ & $\begin{array}{l}4.1-4.3 \\
68-91 \% \\
7.0-7.5 \\
\text { none } \\
\text { ant idiar rheal } \\
\text { and demul cent } \\
\text { powder }\end{array}$ & $\begin{array}{l}2.7 \\
94 \% \\
8.3 \\
\text { none } \\
\text { antidiarrheal } \\
\text { antacid, } \\
\text { dentrifrices, } \\
\text { cosmetics }\end{array}$ & $\begin{array}{l}3.4 \\
90 \% \\
6.0 \\
\text { none } \\
\text { used to treat } \\
\text { iron defi- } \\
\text { ciency anemla }\end{array}$ \\
\hline $\begin{array}{l}\text { Water Solubles** }(\mathrm{mg} / \mathrm{l}) \\
\text { Calclum } \\
\text { Magneslum } \\
\text { Iron } \\
\text { Sodium } \\
\text { Potassium } \\
\text { Barlum } \\
\text { Copper } \\
\text { Zlnc } \\
\text { Lead } \\
\text { Manganese } \\
\text { Blcarbonates } \\
\text { Carbonates } \\
\text { Hydroxides } \\
\text { Sul fates } \\
\text { Chlorides }\end{array}$ & $\begin{array}{c}1-48 \\
1-22 \\
N A+ \\
20-190 \\
0=18 \\
0 \\
0.1=0.2 \\
0.05=0.1 \\
0 \\
0.05-0.2 \\
40-200 \\
5=50 \\
0 \\
70-400 \\
30-190\end{array}$ & $\begin{array}{r}160 \\
0 \\
N A \\
15 \\
0 \\
N A \\
N A \\
N A \\
N A \\
N A \\
730 \\
0 \\
0 \\
0 \\
50\end{array}$ & $\begin{array}{l}8 \\
0 \\
0 \\
2 \\
5 \\
N A \\
N A \\
N A \\
N A \\
N A \\
7 \\
0 \\
0 \\
44 \\
10\end{array}$ \\
\hline
\end{tabular}

* In concentrations up to $100,000 \mathrm{mg} / \mathrm{l}$ introduced into fresh or sea water.

* *obtained after filtering through a $0.2-m i c r o n$ millipore filter.

tNA: not available.

Table 5.31

Typical Drilling Mud Compositions $(|\mathrm{b} / \mathrm{bb}|)^{59}$

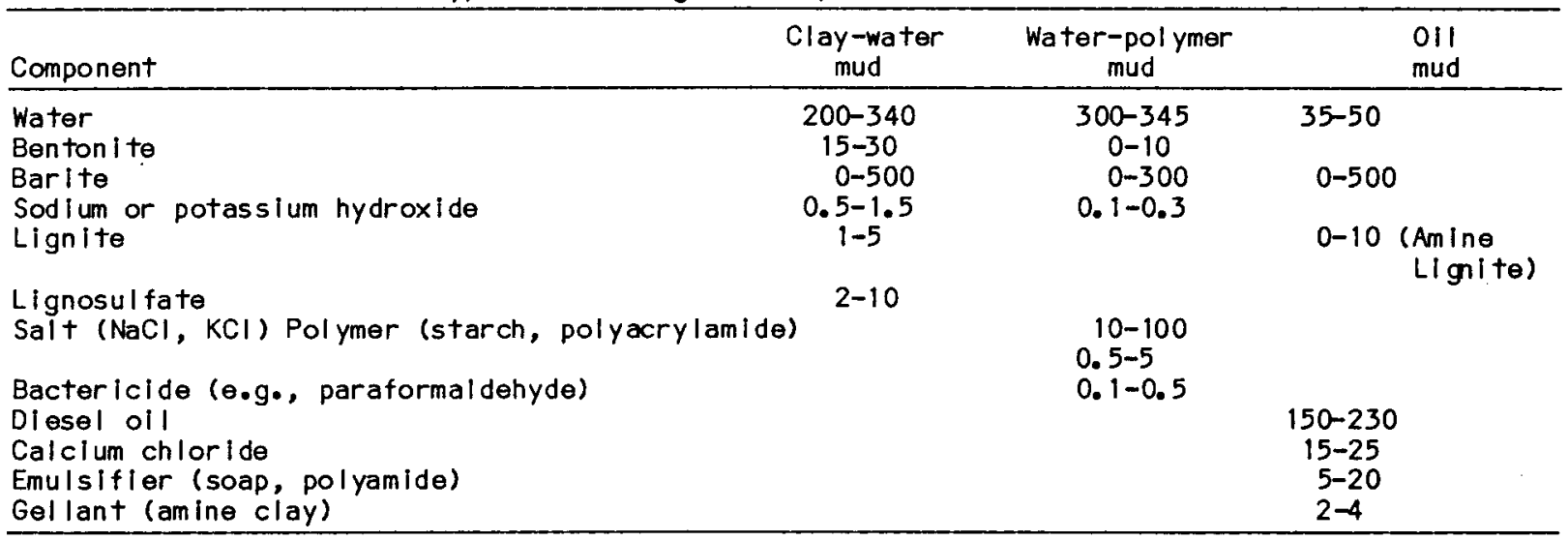


Table 5.32

Miscel laneous Materials Sometimes Used

in Drilling Fluids

\begin{tabular}{|c|c|c|}
\hline Material & Use & Reference(s) \\
\hline $\begin{array}{l}\text { Siderite (iron carbonate), } \\
\text { barite (barium sulfate), } \\
\text { lead sulfide, calcium } \\
\text { bromide }\end{array}$ & Weighting material & $\begin{array}{l}58 \\
61\end{array}$ \\
\hline $\begin{array}{l}\text { Graphite, soaps, } \\
\text { organic polymers, } \\
\text { water-dispersable asphalts, } \\
\text { large-weight alcohols }\end{array}$ & Lubricants & $\begin{array}{l}61 \\
66\end{array}$ \\
\hline $\begin{array}{l}\text { Acids: hydrochloric, } \\
\text { nitric, sulfuric, } \\
\text { hydrofiuoric, formic, acetic, } \\
\text { ethoxylated nonylphenol }\end{array}$ & To increase reservoir permeability & 61 \\
\hline $\begin{array}{l}\text { Emulsifiers: lignosulfates, } \\
\text { alkyl ethylene oxides, } \\
\text { hydrocarbon sulfonates }\end{array}$ & To form oil-in-water or water-in-oil emulsions & 62 \\
\hline $\begin{array}{l}\text { Alcohols, silicones, } \\
\text { sulfonated oils }\end{array}$ & Defoaming agents & 61 \\
\hline $\begin{array}{l}\text { Aluminum sulfate, } \\
\text { calcium sulfate, } \\
\text { ferric sulfate, } \\
\text { bentonites }\end{array}$ & Flocculating or coagulating agents & 61 \\
\hline $\begin{array}{l}\text { Tannins, lignosulfates, } \\
\text { quebracho, lignins, } \\
\text { iron chromel ignosulfonate }\end{array}$ & Dispersion of mud solids & $\begin{array}{l}62 \\
66\end{array}$ \\
\hline $\begin{array}{l}\text { Imidazoline, copper carbonate, } \\
\text { calcium carbonate, iron oxide, } \\
\text { sodium arsenite, coal-tar } \\
\text { derivatives, alkyl phenolethylene } \\
\text { oxide, diethylamine, } \\
\text { acetylenic alcohol-alkyl pyridine }\end{array}$ & Corrosion inhibitors & 61 \\
\hline $\begin{array}{l}\text { Aldehydes (formal dehyde, } \\
\text { paraformal dehyde, } \\
\text { gluteral dehyde) }\end{array}$ & Bactericides & 62 \\
\hline \multicolumn{3}{|l|}{$\begin{array}{l}\text { Chlorinated phenols (penta- } \\
\text { chlorophenol, alkyl di- } \\
\text { chlorophenol, sodium salts of } \\
\text { phenols) }\end{array}$} \\
\hline \multicolumn{3}{|l|}{$\begin{array}{l}\text { Quaternary amines (alkyl } \\
\text { dimethyl ammonium chloride, } \\
\text { coco dimethyl benzyl, } \\
\text { anmon lum chloride) }\end{array}$} \\
\hline$\frac{\text { Diamine salts }}{\text { salts of coco or tallow) }}$ & . & \\
\hline $\begin{array}{l}\text { Bentonite clay, barium carbonate, } \\
\text { gums, starches, I ignosultates, } \\
\text { sulfonated asphalt } \\
\text { Shredded paper, asbestos }\end{array}$ & Filtrate reduction & $\begin{array}{l}63 \\
61\end{array}$ \\
\hline $\begin{array}{l}\text { Cellulose, rubber, sugar cane, } \\
\text { straw, pig hairs, cedar fiber, } \\
\text { groundnut shells, mica, } \\
\text { carbonates, shredded leather, } \\
\text { oll-soluble resins, sodium } \\
\text { polyacrylate, asphalt }\end{array}$ & $\begin{array}{l}\text { Sweep large particles out of hole } \\
\text { Seal against leakage to formation }\end{array}$ & $\begin{array}{l}59 \\
62 \\
66\end{array}$ \\
\hline
\end{tabular}


reserve pits. Unwanted solid constituents include drilled solids, silts, sand, anhydrites, etc., as well as additives which cannot be efficiently removed or reused. Useful solids such as colloidal solids, clays, and weighting materials are returned to the hole. Sequences of screens of smaller sizes remove some solid materials which are usually sent to a waste pit. Sands and silts are removed using hydrocyclones, and these solids are also sent to the waste pit. For a water-based mud, colloidal solids which increase viscosity are discarded to the waste pit, whereas heavier solids (e.g., barite) are reused. Expensive polymers are returned to the mud system. The American Petroleum Institute (API) holds that water-based dri11ing fluids are themselves not usually harmful to humans.64 Allred 65 further reports that "once drilling fluids are mixed, only basic good housekeeping practices and precautions are necessary in handling the drilling fluid."

The predominant ingredients of drilling muds are naturally occurring substances such as barite, bentonite, calcite, siderite, and lignite. Lignite is an intermediate product in the change of humic material to coal.59 These substances are routinely mixed, processed, and delivered to oil flelds in sacks. Other naturally occurring or man-made additives, such as emulsifiers or biocides, are shipped to rigs in sacks or containers. Whether naturally occurring or not, however, some constituents may be considered hazardous or toxic.

Barite, calcite, and siderite are inert, generally insoluble in water, and have been shown to be nontoxic to aquatic life in concentrations up to $100,000 \mathrm{mg} / 1.58$ The effects of $31 \mathrm{drilling}$ muds on green bean and sweet corn were studied by Miller and Honarvar at Utah State University. 66 At normal concentrations, statistically significant (.05 level) reductions in yield occurred with diesel oil, long chain alcohol, guar gum, lignite, potassium chloride, pregelatinized starch, a modified asphalt, and an iron chromolignosulfate. No statistically significant reductions of yield occurred for normal concentrations of asphalt, barite, bentonite, calcium lignosulfate, sodium polyacrylate, a modified tannin, a nonfermenting starch, ethoxylated nonylphenol, a xanthan gum, paraformaldehyde, gilsonite, pipe dope, hydrolyzed polyacrylamide, sodium hydrogen pyrophosphate, sodium carboxymethyl cellulose, sodium hydroxide, a sulfonated tall oil, and a sulfated triglyceride. Yield increases occurred at normal use rates with asbestos and sodium dichromate. The authors concluded that "[r]eclamation procedures... would seem to be relatively simple, with the exception perhaps of the problem with diesel oil, and they involve leaching, additions of gypsum, and time." 66 Weir and Moore ${ }^{63}$ calculated an $L_{50}$ value to rainbow trout for mud concentration of less than $20 \%$ by volume, with the predominant toxic factor being high levels of potassium chloride. Despite the specific use of bactericides to kill living organisms, Robichaux 62 concluded that "by using proper precautions, the environmental hazards [of. bactericides] can be minimized. If bactericides used in drilling and completion do not enter the environment, most will be removed by natural causes." Robichaux 62 indicated that almost complete degradation occurs within 5 days for aldehydes, amines, and quaternary amines. However, this does not hold true for chlorinated phenols. Nevertheless, suitable practices are required for the disposal of drilling fluids containing these substances. Quaternary amines and other amines (cationic bactericides) readily adsorb onto clay. Anionic bactericides, e.g., aldehydes may be adsorbed onto some solls. Aldehydes and amines may 
react with other chemicals in muds to produce nonlethal, but polluting, end products.

Drilling fluids used in future tertiary recovery operations will be more stable under extreme pressures and temperatures, and will remain in pits for long periods of time. Several methods have been developed to properly handle and dispose of these muds. Impermeable linings, dikes, and runoff and leachate recovery systems are commonly used by other industries. Chemical techniques are avallable to solidify drilling muds and cuttings into a nontoxic material which may be added to soil mixtures without detriment to terrestial ecosystems. Table 5.33 presents results of one such solidification technique ${ }^{68}$ using muds from offshore (Gulf of Mexico) and large bargemounted marsh rigs. The same authors present further information (Table 5.34) to demonstrate the ability of their process to bind high concentrations of heavy metal ions within a solid matrix. This particular portable system is reported to be capable of processing 1000 bb1 a day and reducing mud volumes by as much as $75 \%$, at a cost (in 1975) of $\$ 3$ per barrel.

It appears that many of the most commonly found substances in drilling muds are innocuous by themselves or can be properly handled and disposed of using existing technologies. Drilling muds and brines from oil production are not now regulated by the Resource Conservation and Recovery Act (RCRA). However, reference to Table 5.32 indicates the presence of lesser quantities of substances labeled hazardous. Their physical and chemical attributes are not well defined, especially in subsurface environments. Little is known of their degradation or end products. Because of this, drilling muds and brines from crude ofl production and exploration are currently under investigation by the EPA. Pending Congressional amendments to RCRA allow the EPA to initiate appropriate rules if it concludes that these muds and brines should be regulated as hazardous wastes, 69 though final Congressional approval is required. It should be noted that Congressional conferences working on this amendment recognized the need for producers of ofl field brines and fluids to maintain records of produced volumes and disposal sites.

FGD Systems. As discussed previously, combustion of oil in a steam generator produces oxides of sulfur, nitrogen, and carbon. To meet stringent air quality regulations, flue gas desulfurization (FGD) equipment is used with steam generators that burn heavy o11. Cleaning of the flue gases reduces atr pollution, but it also creates a secondary concern: the environmentally safe and cost-effective management of the liquid and solid wastes resulting from the operation of FGD equipment. In a recent document, Layton and Daniels 56 review FGD waste management technologies associated with EOR. They depict the three options for managing wastes from FGD systems (Figure 5.22).

The simplest method of waste management is to dispose of wastes at a surface disposal faclifty. Most of the $\mathrm{SO}_{2}$ control devices presently installed produce liquid wastes, and consequently, a second disposal alternative is subsurface injection. The third option is to recover waste by-products so that they can be marketed for other uses. Key considerations in the selection of the waste management alternatives are the comparative costs of the alternatives, the marketability of by-products, and the ability of a 
Table 5.33

Leachate Analysis of Experimental Mud Solidification Technique 68

General mud characteristics: Weight $11.81 \mathrm{~b} / \mathrm{gal}$

$\%$ Oil 28

\% Water 41

$\%$ Solids 31

\begin{tabular}{lcccccc}
\hline & $\begin{array}{c}\text { Original } \\
\text { Concentration } \\
\text { Constituent }\end{array}$ & \multicolumn{2}{c}{ Leachate Concentration (mg/1) After (Days) } \\
\hline $\mathrm{pH}$ (STD Units) & 10.1 & 1 & 2 & 8 & 15 & 28 \\
\hline $\mathrm{Ca}^{++}$ & & 12.1 & 12.3 & 12.0 & 11.8 & 10.6 \\
$\mathrm{Mg}^{++}$ & 2,720 & $<1.0$ & $<1.0$ & $<1.0$ & $<1.0$ & $<1.0$ \\
$\mathrm{Na}^{+}$ & 4 & 420 & 400 & 260 & 220 & 120 \\
$\mathrm{Cl}^{-}$ & 5,800 & 2,100 & 2,000 & 20 & 10 & 10 \\
$\mathrm{SO}_{4}=$ & 13,100 & 2,750 & 2,600 & 10 & 10 & 8 \\
$\mathrm{~K}^{+}$ & 870 & 50 & 40 & 9 & 3 & 2 \\
$\mathrm{Zn}^{+}$ & 230 & 90 & 40 & 5 & 3 & 2 \\
$\mathrm{Cr}^{+++}$ & 2 & $<0.1$ & $<0.1$ & $<0.1$ & $<0.1$ & $<0.1$ \\
$\mathrm{Ni}^{++}$ & 1 & $<0.1$ & $<0.1$ & $<0.1$ & $<0.1$ & $<0.1$ \\
$\mathrm{Mn}^{++}$ & 1 & 0 & 0 & 0 & 0 & 0 \\
$\mathrm{Fe}^{++}$ & 1 & 0 & 0 & 0 & 0 & 0 \\
\hline
\end{tabular}

Table 5.34

Experimental Leachate Solidification Process 68

Using High Concentration of Heavy Metal Ions

(Mud weight $11.6 \mathrm{lb} / \mathrm{gal} ; 28$-day-equiv. inches of rain)

\begin{tabular}{lccccc}
\hline Constituent & $\begin{array}{c}\text { In Original } \\
\text { Mud }\end{array}$ & $\begin{array}{c}\text { Criginal Mud } \\
\text { Filtrate }\end{array}$ & $\begin{array}{c}\text { 1-Day } \\
\text { Leachate }\end{array}$ & $\begin{array}{c}\text { 7-Day } \\
\text { Leachate }\end{array}$ & $\begin{array}{c}\text { 28-Day } \\
\text { Leachate }\end{array}$ \\
\hline $\mathrm{Cr}^{++}$ & 1388 & 550 & $<0.1$ & $<0.1$ & $<0.1$ \\
$\mathrm{Zn}^{++}$ & 2800 & 60 & $<0.1$ & $<0.1$ & $<0.1$ \\
$\mathrm{Mn}^{++}$ & 2522 & 210 & $<0.1$ & $<0.1$ & $<0.1$ \\
$\mathrm{Co}^{++}$ & 285 & 3 & $<0.1$ & $<0.1$ & $<0.1$ \\
$\mathrm{Fe}^{++}$ & 13,300 & 100 & $<0.1$ & $<0.1$ & $<0.1$ \\
$\mathrm{pH}$ & 10 & 8.3 & --1 & --- & -- \\
\hline
\end{tabular}


Alternative sources and fuels for steam generation

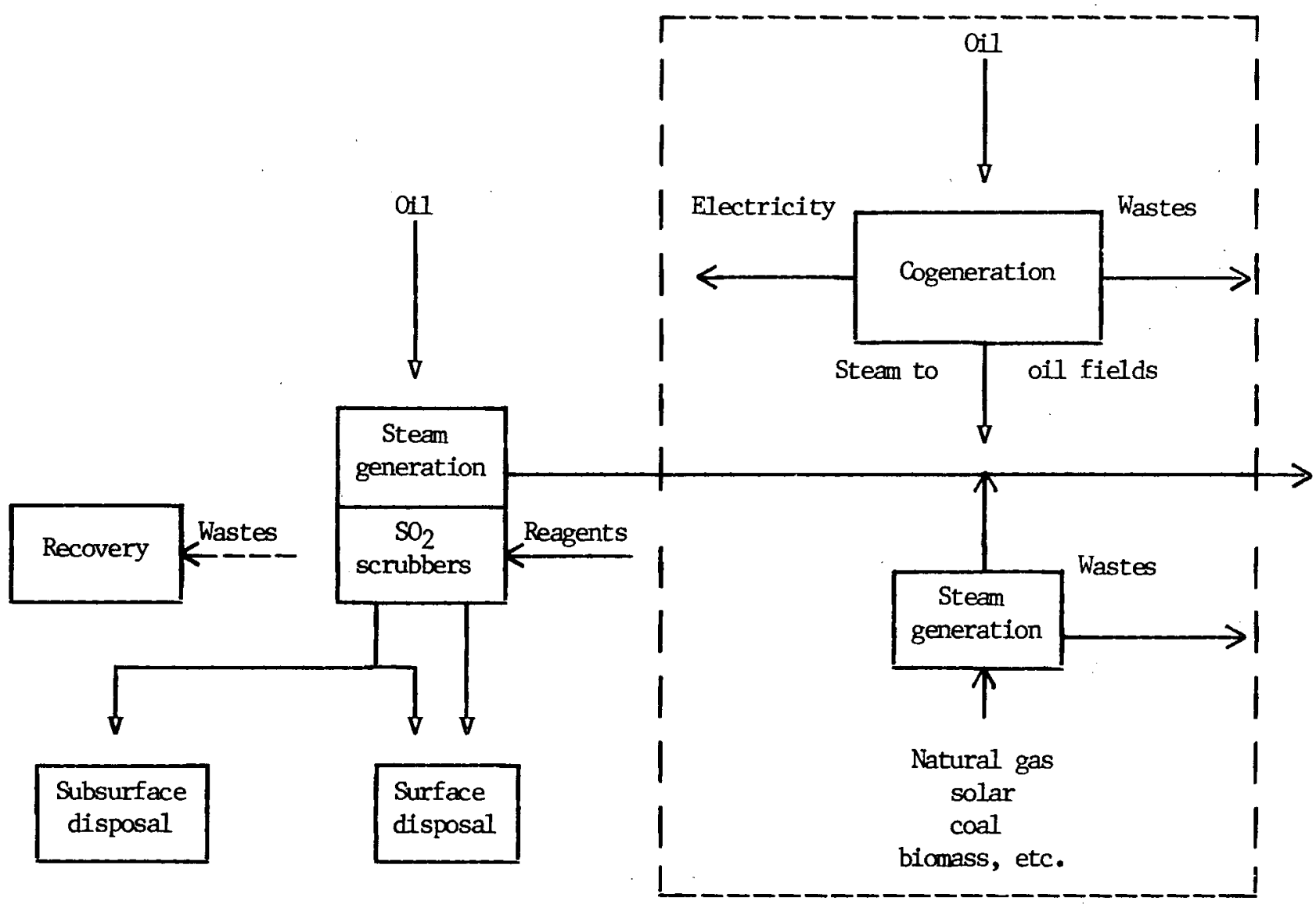

Figure 5.22 Options for managing wastes from FGD systems.56

disposal method to handle the quantities of wastes that will be produced over periods of up to 25 years or more. Furthermore, regulations promulgated under the Resource Conservation and Recovery Act and the Safe Drinking Water Act, as well as applicable State laws, will directly influence the availability of the surface and subsurface disposal options. Stricter disposal regulations together with cost-reducing incentives will also make the manageability of FGD wastes a more important factor in the operation and selection of $\mathrm{SO}_{2}$ control devices.

There are several FGD methods applicable to oil-fired steam generators used in TEOR. Table 5.35 presents a comparison of eleven such technologies which fa11 into the regenerable/nonregenerable categories. These processes involve a range of water requirements and produce different amounts of solids of different composition.

The open literature on the chemical characterization of FGD wastes is sparse, particularly vis-a-vis potentially toxic elements. Layton and Daniels 56 have analyzed sludges taken from FGD systems operating in Kern 
Table 5.35

Comparison of FGD Systems on TEOR OII-Fired Steam Generators 70

NONEGENERABLE PROCESSES

\begin{tabular}{|c|c|c|c|c|c|c|c|c|c|c|c|}
\hline & $\begin{array}{c}\text { Sod lum } \\
\text { Carbo- } \\
\text { nate }\end{array}$ & Ammonia & $\begin{array}{l}\text { Lime- } \\
\text { stone }\end{array}$ & $\begin{array}{l}\text { Lime- } \\
\text { stone } \\
\text { IChly- } \\
\text { oda }\end{array}$ & LIme & $\begin{array}{l}\text { Double } \\
\text { Alkali }\end{array}$ & $\begin{array}{l}\text { Dry } \\
\text { Scrub- } \\
\text { bing }\end{array}$ & $\begin{array}{l}\text { Citrate } \\
\text { (St. Joe } \\
\text { Zinc Co.) }\end{array}$ & $\begin{array}{l}\text { Wel Iman } \\
\text {-Lord } \\
\text { (Sod lum } \\
\text { SuIfite) }\end{array}$ & $\begin{array}{l}\text { Mag- } \\
\text { nes lum } \\
\text { Oxide }\end{array}$ & $\begin{array}{c}\text { Carbon } \\
\text { Adsorption }\end{array}$ \\
\hline \multicolumn{12}{|l|}{ Economics $\left(\times 10^{3} \$\right)^{a}$} \\
\hline $\begin{array}{l}\text { Total capltal Investment } \\
\text { Net annual cost } \\
\text { (incl. credits for by } \\
\text { Unit annual cost }\end{array}$ & $\begin{array}{r}967 \\
592 \\
\text { ducts, or }\end{array}$ & $\begin{array}{c}1000 \\
530 \\
\text { ergy, etc.) }\end{array}$ & $\begin{array}{r}1469 \\
581\end{array}$ & $\begin{array}{r}1379 \\
571\end{array}$ & $\begin{array}{r}1523 \\
594\end{array}$ & $\begin{array}{r}1529 \\
614\end{array}$ & $\begin{array}{r}2378 \\
827\end{array}$ & $\begin{array}{r}1963 \\
746\end{array}$ & $\begin{array}{r}2038 \\
624\end{array}$ & $\begin{array}{r}2251 \\
744\end{array}$ & $\begin{array}{l}3089 \\
1174\end{array}$ \\
\hline $\begin{array}{l}\$ / \text { bb oll burned } \\
\$ / 10^{6} \text { Btu inp ut }\end{array}$ & $20^{1.2}$ & $18^{1.12}$ & $19^{1.22}$ & $19^{1.20}$ & $20^{1.25}$ & $20^{1.29}$ & $28^{1.74}$ & $25^{1.57}$ & $21^{1.31}$ & $25^{1.57}$ & 39 \\
\hline By-product/waste mgt & DLP & DLP & DLP & $\begin{array}{l}\text { Gypsum } \\
\text { produc- } \\
\text { tion } \\
(1100 \\
(\mathrm{b} / \mathrm{hr})\end{array}$ & DLP & DLP & $\begin{array}{l}\text { Hau laway } \\
\text { of waste }\end{array}$ & $\begin{array}{l}y \text { Liquid } \\
\mathrm{SO}_{2} \\
(396 \\
\mathrm{l} / \mathrm{br})\end{array}$ & $\begin{array}{l}\text { Llquid } \\
\mathrm{SO}_{2} \\
(360 \\
\text { (b/hr) }\end{array}$ & $\begin{array}{l}\mathrm{H}_{2} \mathrm{SO}_{4} \\
\text { produc- } \\
\text { tion } \\
(528 \\
\text { lb/hr) }\end{array}$ & $\begin{array}{l}\text { Sulfur } \\
\text { produc- } \\
\text { tion } \\
(125 \\
\text { (b/hr) }\end{array}$ \\
\hline $\begin{array}{l}\text { Av pond } \mathrm{size}^{\mathrm{a}}(\mathrm{AFt}) \\
\text { Flow }(\mathrm{gpm}) \\
\quad(1000 \mathrm{lb} / \mathrm{hr}) \\
\text { Water }(1000 \mathrm{~b} / \mathrm{hr}) \\
\text { Est. solids }(1000 \mathrm{lb} / \mathrm{hr})\end{array}$ & $\begin{array}{r}33.3 \\
8.8 \\
5.06 \\
4.3 \\
0.7\end{array}$ & $\begin{array}{r}27.3 \\
6.8 \\
3.74 \\
3.06 \\
0.68\end{array}$ & $\begin{array}{l}57.0 \\
1.7 \\
1.49 \\
0.60 \\
0.89\end{array}$ & $\begin{array}{l}1.33 \\
0.23 \\
1.10\end{array}$ & $\begin{array}{l}52.0 \\
2.36 \\
1.35 \\
0.54 \\
0.81\end{array}$ & $\begin{array}{l}50.0 \\
-0 \\
1.37 \\
.53 \\
.84\end{array}$ & $\begin{array}{l}\text { (c) } \\
1.29 \\
.07 \\
1.22\end{array}$ & $\begin{array}{l}6.6 \\
0.341 \\
0.28 \\
0.061\end{array}$ & $\begin{array}{l}3.9 \\
.44 \\
.31 \\
.23 \\
.08\end{array}$ & & \\
\hline Carbonate & -- & --- & 62 & --- & & 27.1 & 219 & & & & \\
\hline Hyposulfite $\quad \mathrm{lb} / \mathrm{hr}$ & 200 & 316 & -- & -- & -- & -- & - & & -- & & \\
\hline $\begin{array}{l}\text { Sulfite } \\
\text { Sulfate }\end{array}$ & $\begin{array}{l}421 \\
132\end{array}$ & $\begin{array}{l}238 \\
121\end{array}$ & $\begin{array}{l}371 \\
421\end{array}$ & --- & $\begin{array}{l}678 \\
135\end{array}$ & $\begin{array}{l}678 \\
134\end{array}$ & $\begin{array}{l}624 \\
380\end{array}$ & 55 & $\begin{array}{l}50.7 \\
15.1\end{array}$ & & \\
\hline $\begin{array}{l}\text { Service water regmt } \\
\text { Flow }(1000 \mathrm{lb} / \mathrm{hr})\end{array}$ & 33.2 & 36.0 & 28.85 & 30 & 28.4 & 29.5 & 27.3 & 14.5 & 10.6 & 29.5 & 26.0 \\
\hline $\begin{array}{l}\text { Alr emissions } \\
\mathrm{N}_{2} \text { vol } \$ \\
\mathrm{CO}_{2} \text { vol } \%\end{array}$ & & & & & & & $\begin{array}{l}73.12 \\
12.17 \\
\end{array}$ & & & & \\
\hline
\end{tabular}

a. Design basis: $300 \times 10^{6}$ Btu/hr total heat output from 6 steam generators manifolded in one FGD system, using $1.14 \%$ sulfur in crude oll, $90 \% \mathrm{SO}_{2}$ removal, $90 \%$ load factor, pond II fe 20 years.

b. DLP = disposal in I ined pit; dash shows item not applicable; blank is an unknown value.

c. Assume supplier of trona hauls solld waşte back to mines (trona is a mineral containing $\mathrm{Na}_{2} \mathrm{CO}_{3}$ and $\mathrm{NaHCO}_{3}$.

d. Design air emissions: Flow is $96 \times 10^{3} \mathrm{acfm}\left(361 \times 10^{3} \mathrm{ib} / \mathrm{hr}\right) ; \mathrm{H}_{2} \mathrm{O}$ in flue gas into scrubber is $23.12 \times 10^{3}$ ib/hr, and $\mathrm{H}_{2} \mathrm{O}$ out of scrubber is $51.13 \times 10^{3} \mathrm{lb} / \mathrm{hr}$; Al I $\mathrm{FGO}$ systems were designed to meet proposed CARB sulfur regulation I imiting sulfur emissions to $0.058 \mathrm{Ib} / 10^{6}$ Btu input. This is a $90 \% \mathrm{SO}_{2}$ removal ef ficlency based on assumption that all sulfur compounds in flue gas are present as $\mathrm{SO}_{2}$. Wet $\mathrm{SO}_{2}$ flow rate is $440 \mathrm{lb} / \mathrm{hr}$ implying removal of $396 \mathrm{lb} \mathrm{SO}_{2} / \mathrm{hr}$. $\mathrm{No}$ removal efficlencies specifled for ash, trace metals or $\mathrm{NO}$. 
County, California (Tables 5.36 to 5.37). The concentrations of suspended solids in the FGD fluids from nonregenerable sodium-based systems ranged upward from $30 \mathrm{mg} / \mathrm{l}$, with a geometric mean of $120 \mathrm{mg} / \mathrm{l}$. Nickel ranged from 0.76 to $6.86 \%$ by weight in the suspended solids, while sodium ranged from 0.54 to $8.29 \%$ by weight.

Atmospheric Fluidized-Bed Combustion Systems. (This subsection is condensed from ref. 56. The authors thank Messrs. Layton and Daniels for their kind permission to do so.)

An alternative to oil-fired steam generators would be the use of coal-fired atmospheric fluidized-bed combustion (AFBC) boilers. These systems are more attractive than conventional coal-combustion steam generators because $\mathrm{SO}_{2}$ can be effectively controlled during combustion, precluding the need for expensive FGD systems. In addition, nitrogen oxide

Table 5.36

Concentration Ranges for B, Co, Na, Ni, Se, V, and Total Dissolved Solids in Four Different Samples of Liquid Wastes From FGD Systems Operating in Kern County 56

\begin{tabular}{llcc}
\hline & & \multicolumn{2}{c}{ Concentrations in $\mathrm{mg} / \ell$} \\
\cline { 3 - 4 } Elemant & $\begin{array}{c}\text { Analytical } \\
\text { Method }\end{array}$ & minimum & maximum \\
\hline B & ICP/OES & 5.71 & 169.1 \\
$\mathrm{Co}$ & INAA & 0.01 & 0.56 \\
$\mathrm{Na}$ & INAA & 33.69 & 28,310 \\
$\mathrm{Ni}$ & INAA & 0.29 & 19.51 \\
$\mathrm{Se}$ & INAA & 0.04 & 0.72 \\
V & ICP/OES & 5.3 & 16.3 \\
TDS* & Gravimetric & 11,366 & 109,676 \\
\hline
\end{tabular}

*Total dissolved solids.

Table 5.37

Chemical Composition of Sludge From a Double-Alkali System 56

\begin{tabular}{cccc}
\hline Element & $\begin{array}{c}\text { Concentration } \\
(\mu \mathrm{g} / \mathrm{g})\end{array}$ & $\begin{array}{c}\text { Standard } \\
\text { deviation }\end{array}$ \\
\hline $\mathrm{As}$ & 2.28 & \pm & 0.39 \\
$\mathrm{Br}$ & 2.70 & \pm & 0.22 \\
$\mathrm{Ca}$ & 238,200 & \pm & 3,365 \\
$\mathrm{Co}$ & 7.41 & \pm & 0.23 \\
$\mathrm{Cr}$ & 8.05 & \pm & \pm \\
$\mathrm{Fe}$ & 1,027 & \pm & 61 \\
$\mathrm{Na}$ & 55,500 & \pm & 732 \\
$\mathrm{Ni}$ & 397 & \pm & 24 \\
$\mathrm{Se}$ & 4.46 & \pm & 0.51 \\
$\mathrm{Zn}$ & 5.03 & \pm & 1.46 \\
\hline
\end{tabular}


emissions are lower because of $\mathrm{AFBC}$ combustion chemistry, and because operating temperatures of $A F B C$ systems are reduced by increased heat transfer between combustion products and boiler tubes. Furthermore, AFBC waste is different from that produced by FGD processes because it is dry and contains calcium sulfate and not calcium sulfite, which is mechanically unstable, and is thus more manageable and acceptable for land disposal, as well as less costly to process.

In an $A F B C$ air, preheated by flue gas, enters the plenum (an air chamber designed to temper air surges or pressure pulses) and is then distributed uniformly over the bed area, suspending the solid particles of the bed as it passes through. The bed itself consists of ash, inert material, reacted and unreacted sorbent, and unburned carbon. The coal and sorbent (usually limestone) are introduced into the boiler by feeder devices (e.g., screw feeders, spreader-stokers, or pneumatic air conveyors). The coal devolatilizes, but most of the volatile matter burns above the feed point, and the remaining solid char burns uniformly throughout the bed. The limestone $\left(\mathrm{CaCO}_{3}\right)$ undergoes calcination to lime $(\mathrm{CaO})$, and some of the lime then reacts with the sulfur dioxide to form calcium sulfate $\left(\mathrm{CaSO}_{4}\right)$.

The $\mathrm{Ca} / \mathrm{S}$ ratio determines the amount of sulfur retained as $\mathrm{CaSO}_{4}$ and the amount of unreacted lime that passes into the waste material. Depending on the properties of the coal, the $\mathrm{Ca} / \mathrm{S}$ ratio, and reactor design, temperatures between $1400^{\circ}$ and $1500^{\circ} \mathrm{F}\left(760^{\circ}\right.$ to $\left.816^{\circ} \mathrm{C}\right)$ are expected. 71

As mentioned earlier, the air and combustion gases passing through the bed cause the solid particles to be suspended by the upward turbulent flow. Particles are agitated and carried into the empty space above the bed. The heaviest particles fall back into the bed, but the lighter ones are entrained in the exhaust gases and carried through the over-bed heating area and out to a particulate collection system (e.g., cyclone followed by secondary particle recovery in a bag filter). The particles are then separated into two streams: one stream is reinjected into the bed for additional combustion, the other stream is combined with rejected bed material (e.g., large ash particles too heavy to be entrained in combustion gases, spent sorbent, unreacted lime, and unburned carbon) and collected for disposa1.

Heat transfer depends on the arrangement of the tube bundles or water walls used for circulating the water that is converted to steam. Furthermore, to ensure complete combustion and maximum heat recovery, secondary over-bed air injection is employed to volatilize unburned solid material carried into the space above the bed space.

On the basis of data from small-scale tests, AFBC systems are anticipated to control $\mathrm{SO}_{2}$ and $\mathrm{NO}_{\mathrm{x}}$ emissions to levels consistent with both EPA New Source Performance Standards (NSPS) for new large coal-fired bollers and the more stringent California standards. For instance, if AFBC units with a $90 \%$ $\mathrm{SO}_{2}$ removal efficiency were to be used to recover heavy oil in Kern County reservoirs and burn low-sulfur Western coal with a high heating value of $11,140 \mathrm{Btu} / 1 \mathrm{~b}$ and a sulfur content of $0.43 \%$ by weight, 72 the maximum $\mathrm{SO}_{2}$ emission rate would be $0.081 \mathrm{~b}$ per $10^{6} \mathrm{Btu}$ or $0.041 \mathrm{~b}$ of sulfur per $10^{6} \mathrm{Btu}$. Both figures are less than current Federal and California State NSPS. 
Table 5.38

Discharge of Major Constituents in the Waste From a Reference Atmospheric Fluidized-Bed Combustion Processa

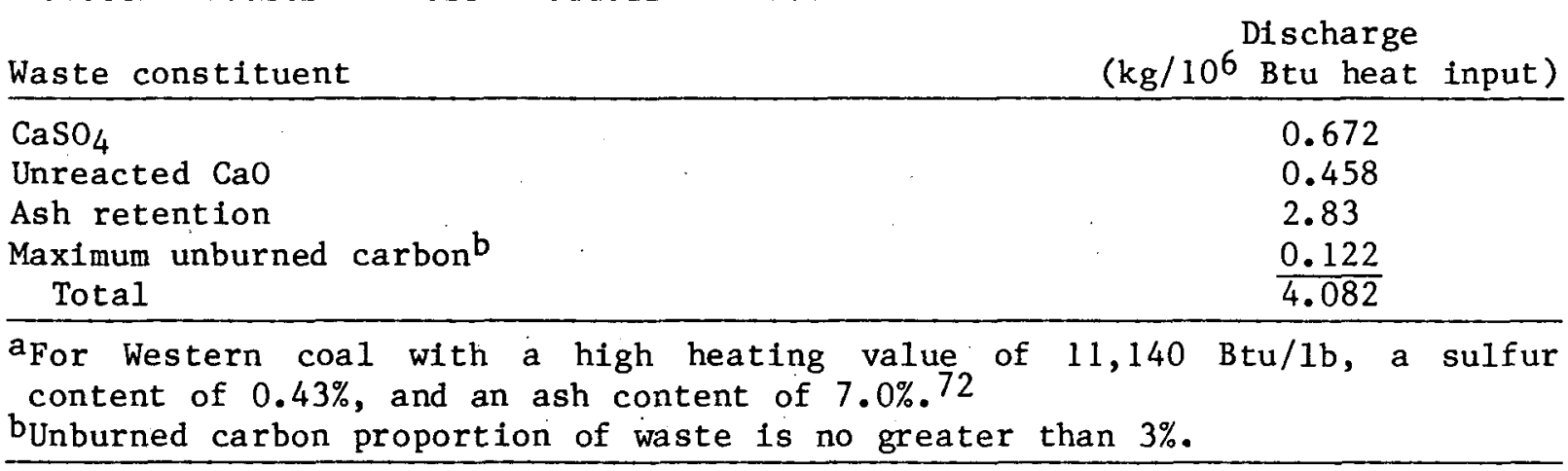

Unfortunately, AFBC technology is just emerging in the U.S. and only a few small systems are operating. Therefore, the nature and quantities of waste that would be produced by commercial AFBC boilers used exclusively for thermal extraction of heavy oil from reservoirs in Kern County, California, can only be approximated. The estimated discharge of major constitutents in the waste from a reference $A F B C$ system corresponding to $380 \times 10^{6} \mathrm{Btu} / \mathrm{h}$ of heat input are presented in Table 5.38. These figures were derived on the basis of operating parameters and the composition of the solid waste predicted for hypothetical commercial AFBC processes designed for a 1000-MWe electric power plant operating with $90 \%$ removal of $\mathrm{SO}_{2} .71,73$ Major inorganic elements predicted to be present in the ash are aluminum, iron, silicon, potassium, calcium, and carbon (noncarbonate). The ash will also contain volatile and potentially toxic elements such as arsenic, beryllium, cadmium, mercury, lead, selenium, antimony, and tellurium. 71 The concentrations of elements detected in an analysis of material from an AFBC bed will depend on the properties of the coal and operating behavior of individual systems. A paramount concern related to leaching of substances from the waste is contamination of ground and surface water by calcium and sulfate ions present in the waste.

\subsubsection{Regulations and Issues}

As in the case of air and water quality, there are federal and state laws which regulate waste disposal. The most important federal law governing the disposal of wastes is the Resource Conservation and Recovery Act of 1976 (RCRA). Under Section 3004: of Subtitle C of this law, a hazardous waste (i.e., a waste specifically classifled as hazardous in regulations or a waste that exhibits, through testing, one of the following characteristics: ignitability, corrosivity, reactivity, .or toxicity) must be disposed of in a hazardous waste disposal facility. For example, it is possible that scrubber waste, could be classified as toxic. However, in an interim rule the EPA has specifically classified as nonhazardous those wastes associated with combustion of coal or other fossil fuels (e.g., fly ash, bottom ash, waste from the 
cleaning of flue gases).74 This classification is subject to change in the years ahead after the EPA completes research dealing with the disposal of wastes derived mainly from the operation of coal-fired power plants. In the meantime, the nonhazardous designation means that producers of FGD wastes would have some flexibility in disposing of their wastes. According to Section 4003 of Subtitle D in RCRA, nonhazardous wastes can be disposed of in sanitary landfills "or otherwise disposed of in an environmentally sound manner."

The degree to which solid waste impacts may constrain EOR production depends upon how government regulators classify these wastes. Some states (e.g., California) classify scrubber sludges from crude-oil-fired boilers as hazardous, requiring specially secured disposal sites. Such sites are often few in number and usually require transportation over great distances at high costs. This issue is as yet unresolved in many states, and will be decided in the future as administrative and other courts rule on litigation brought by industry, trade associations, regulatory agencies, or protesting citizenry.

It should also be noted, however, that several states elther have already recognized the potential toxicity of some drilling muds, or are considering doing so. In California, for example, EOR-related wastes which are discharged to land have been grouped as either 75 :

Group 1 Wastes consisting of or containing toxic substances and substances which could significantly impair the quality of usable waters.

Group 2 Wastes consisting of or containing chemically or biologically decomposable material which includes neither toxic substances nor those capable of significantly impairing the quality of usable waters.

Hazardous waste is defined on the basis of ability to cause (or significantly contribute to an increase in) mortality or an increase in serious, irreversible, or incapacitating reversible illness, or a waste which may pose a Hazardous waste is defined on the basis of ability to cause (or significantly contribute to an increase in) mortality or an increase in serious, irreversible, or incapacitating reversible illness, or a waste which may pose a substantial present or potential hazard to human health or environment when improperly treated, stored, transported, or disposed of, or otherwise managed. (California Administrative Code, Title 23, Chapter 3, Subchapter 15 -- Waste Disposal to Land, Article 1, Sec. 2500.) However, because of variations in their characteristics, drilling muds span both categories.75 Brines from oil well production and rotary drilling muds are discussed in California waste disposal law (California Administrative Code, Title 23, Chapter 3, Subchapter 15, Article 1, Section 2520(b)). Commentary on this particular section [1.e., 2520(b)] includes the following ${ }^{75}$ :

"In most instances, fluids containing dissolved salt concentrations in excess of quality required for irrigation must be prevented from percolating to fresh groundwater and thus are considered a Group 1 waste. The wastes derived from geothermal electric generating plants, fossil fuel electric generating plants, refineries and 
units required to clean up air discharges can contain substantial quantities of sulfur, radon, boron, and heavy metals. An evaluation of fixation, cementation, and solubility of these wastes must be made on an individual basis to determine the threat to water quality. In most instances, if not fixed in a nonsoluble form, these materials contain sufficient toxic hazardous materials to be included as Group 1 waste. The usual toxic materials found in drllling mud are chromium compounds used for thinning agents.

(Emphasis added.)

Those substances which are commonly referred to in California codes as hazardous include arsenic, mercury, nickel, cyanide, lead, cadmium, chromium, silver, copper, zinc, and total identifiable chlorinated hydrocarbons. A recent report (ref. 56) indicates that California will likely soon adopt a more flexible approach to solid waste disposal:

Under current state regulations, a waste is classified as hazardous if it contains detectable amounts of one or more of the toxic substances listed in the regulations. This rigid classification system is likely to be replaced with a more reasonable one that has been proposed by the California Department of Health Services. With the proposed regulations, a waste producer will classify a waste by following a set of procedures found in the California Assessment Manual for Hazardous Wastes. 76 Wastes will be assessed in terms of these attributes: toxicity, flammability, reactivity, corrosion/irritation, and sensitization. Each of those properties is evaluated through various tests and measurements prescribed in the manual. A waste mixture containing toxic substances could be classified as nonhazardous if, after following the assessment procedures, the waste producer finds that the waste does not exhibit hazardous properties. At that point the producer would petition the Department of Health Services for a nonhazardous designation. Both the existing and proposed regulations provide for variances in cases when a waste, though exhibiting hazardous properties, does not pose a threat to human health, domestic livestock, or wildlife. 56

The State of Oklahoma has published extensive rules and regulations for

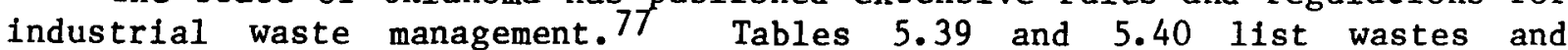
chemicals which may cause a waste product to be designated as Controlled Industrial Waste, and thereby subject to more stringent disposal requirements.

\subsubsection{Scenario}

The solid wastes scenario of Table 5.41 was generated from information for nonregenerative sodium carbonate scrubbers given in ref. 56. Assuming that such a FGD system produces about " $6 \mathrm{~kg}$ total waste (scrubber sludge) per $10^{6} \mathrm{Btu}$ input for fuel whose sulfur content is in the range of $1 / 2$ to $2-1 / 2 \%$ leads to a result of some $33.3 \mathrm{~kg}(73 \mathrm{lb})$ of scrubber sludge per barrel of crude burned. However, $15 \%$ or only $5 \mathrm{~kg}$ ( $11 \mathrm{lb}$ ) per barrel actually consists of sodium compounds while the remainder is water. 
Table 5.39

Oil Production Wastes Which May Be Controlled by Oklahoma Law 77

Acid or caustic sludges (C)
Bag house wastes
Boiler cleaning waste (T,C)
Corrosion inhibitors (T,C)
Drilling fluids
Drilling mud
Lime and sulfur sludge (C)
Lime sludge (C)
Lime wastewater (C)

Oil (of petroleum origin) $(T, F)$

Oil and water ( $T$ )

Oil ash $(\mathrm{T}, \mathrm{C})$

Soda ash (C)

Solvents (F)

Spent acids or caustics (C)

Sulfonation oil (F)

Tank bottom sediment

Tank cleaning sludges

Waste chemicals

$\begin{array}{ll}\text { Key: } & C \text { - Corrosive or irritant } \\ & F-\text { Flammable } \\ & T-\text { Toxic } \\ \text { Blank - Unclassified as yet }\end{array}$

Table 5.40

Chemicals Which May Cause Tertiary Oil Production Wastes to be Controllable Under Oklahoma Law 77

\begin{tabular}{|c|c|}
\hline 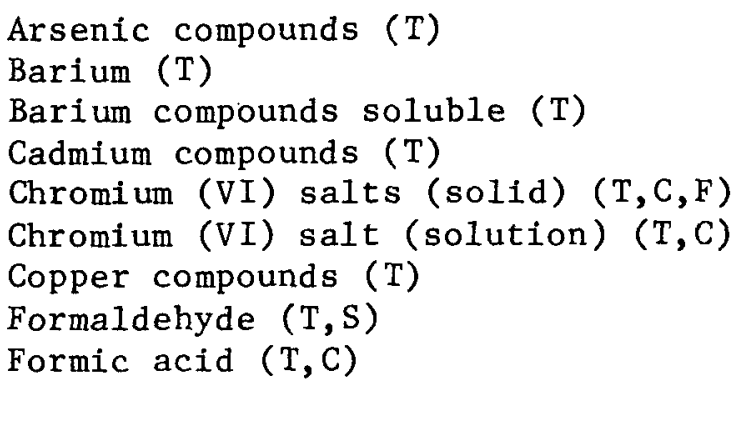 & $\begin{array}{l}\text { Glutaraldehyde (S) } \\
\text { Hydrochloric acid (T,C) } \\
\text { Hydrofluoric acid }(\mathrm{T}, \mathrm{C}) \\
\text { Lead compounds } \\
\text { Mercury compounds }(\mathrm{T}) \\
\text { Nitric acid (T,C) } \\
\text { Pentachlorophenol (T) } \\
\text { Phenol (T,C) } \\
\text { Pyridine (T,F) } \\
\text { Sodium arsenate (T) }\end{array}$ \\
\hline $\begin{array}{ll}\text { Key }: & \text { C - Corrosive or irritant } \\
& \text { F - Flammable } \\
& \text { S - Strong sensitizer } \\
& \text { T - Toxic } \\
& \text { Blank - Unclassified as yet }\end{array}$ & \\
\hline
\end{tabular}

In the scenario it is assumed that oils high in sulfur content $(\sim 4 \%)$ would produce twice as much scrubber wastes, while very low sulfur crudes $(\sim 0.1$ or $0.2 \%)$ would produce an order of magnitude less. It should be noted that regenerative systems like the double alkali system described in ref. 57 would produce only about $8.9 \mathrm{~kg}(19.6 \mathrm{lb})$ of scrubber sludge per barrel of crude burned, although the amounts of alkaline sulfates and carbonates remain about the same, namely $5.4 \mathrm{~kg}$ (12 Ibs) per barrel burned. Typically $61 \%$ of the sludge is made up of hydrated sulfates and carbonates, while the remainder is water. 


\begin{tabular}{|c|c|c|c|c|c|c|c|}
\hline \multirow[b]{3}{*}{ ST } & \multirow[b]{3}{*}{ County or Parish } & \multicolumn{4}{|c|}{$\begin{array}{c}\text { Table } 5.41 \\
\text { Solid Wastes From EOR Environmental Scenario } \\
\text { (Steamflood) } \\
\text { Solid Wastes ( } \mathrm{xlO}^{3} \text { tons } / \mathrm{yr} \text { ) }\end{array}$} & & \\
\hline & & \multirow{2}{*}{$\begin{array}{l}\text { Gross Oil } \\
\text { Production } \\
\text { BOPD }\end{array}$} & \multirow{2}{*}{$\begin{array}{l}\text { Sulfur } \\
\text { Content } \\
\text { of Oil } \\
(\%)\end{array}$} & \multirow[b]{2}{*}{$\begin{array}{l}\text { Scrubber } \\
\text { Solids }\end{array}$} & \multirow[b]{2}{*}{$\begin{array}{l}\text { Scrubber } \\
\text { Sludge }\end{array}$} & \multicolumn{2}{|c|}{ State Totals } \\
\hline & & & & & & $\begin{array}{l}\text { Scrubber } \\
\text { Solids }\end{array}$ & $\begin{array}{l}\text { Scrubber } \\
\text { Sludge }\end{array}$ \\
\hline $\mathrm{AR}$ & Quachita \& Union & 34,700 & 1.4 and 2.4 & 23.0 & 155 & 23.0 & 155 \\
\hline $\mathrm{CA}$ & $\begin{array}{l}\text { Fresno } \\
\text { Kern } \\
\text { Los Angeles* } \\
\text { Monterey } \\
\text { Orange } \\
\text { San Luis Obispo** } \\
\text { Santa Barbara } \\
\text { Ventura }\end{array}$ & $\begin{array}{r}10,000 \\
450,240 \\
106,006 \\
53,260 \\
38,900 \\
5,720 \\
122,300 \\
47,180 \\
\end{array}$ & $\begin{array}{l}0.4 \\
0.6 \\
1.2 \\
2.0 \\
1.2 \\
4.1 \\
4.1 \\
2.0\end{array}$ & $\begin{array}{r}6.2 \\
298 \\
70.2 \\
35.3 \\
25.8 \\
7.58 \\
162 \\
31.3 \\
\end{array}$ & $\begin{array}{c}44.5 \\
2,010 \\
472 \\
237 \\
173 \\
51.0 \\
108.9 \\
210\end{array}$ & 637 & 4,281 \\
\hline $\mathrm{KS}$ & Allen & 151 & $?$ & 0.10 & 0.672 & 0.10 & 0.67 \\
\hline $\mathrm{KY}$ & Warren \& Butler & 12,000 & $?$ & 7.95 & 53.4 & 7.95 & 53.4 \\
\hline IA & $\begin{array}{l}\text { Caddo } \\
\text { Iberville } \\
\text { Saint Landry }\end{array}$ & $\begin{array}{r}31,600 \\
7,790 \\
5,250 \\
\end{array}$ & $\begin{array}{l}0.4 \\
0.1 \\
0.1\end{array}$ & $\begin{array}{l}20.9 \\
0.52 \\
0.35\end{array}$ & $\begin{array}{r}141 \\
3 \\
2.34\end{array}$ & 21.77 & 147 \\
\hline$\alpha \mathbf{K}$ & Stephens & 2,050 & 0.2 & 0.14 & 0.91 & 0.14 & 0.91 \\
\hline $\mathrm{TX}$ & $\begin{array}{l}\text { Hardin } \\
\text { Maverick \& Zavala }\end{array}$ & $\begin{array}{r}2,320 \\
34,200 \\
\end{array}$ & $\begin{array}{c}0.1 \\
?\end{array}$ & $\begin{array}{l}0.15 \\
25.4 \\
\end{array}$ & $171^{1.03}$ & 25.5 & 172 \\
\hline WY & $\begin{array}{l}\text { Big Horn } \\
\text { Fremont } \\
\text { Natrona } \\
\text { Park }\end{array}$ & $\begin{array}{r}21,600 \\
3,080 \\
1,330 \\
2,330 \\
\end{array}$ & $\begin{array}{c}? \\
2 \cdot 1 \\
? \\
?\end{array}$ & $\begin{array}{r}14.31 \\
2.04 \\
0.83 \\
1.45\end{array}$ & $\begin{array}{r}96.3 \\
13.7 \\
5.57 \\
9.75\end{array}$ & 18.6 & 126 \\
\hline & $\begin{array}{l}\text { Placerita, W } \\
\text { Arroyo Grand } \\
\end{array}$ & $\begin{array}{l}\text { Canyon } \\
\text { dalupe. }\end{array}$ & mington. & & & & \\
\hline
\end{tabular}

If non-regenerative FGD systems were used, Kern, Santa Barbara, and Los Angeles counties might produce, respectively, 2010, 1089, and 472 tons/year of scrubber sludges by the year 2000, given the average figures for ofl production on the far left of Table 5.40. In other California counties the problem appears to be at least an order of magnitude smaller than it is in Kern, while in other states with TEOR, the amounts of sludges to be handled drop by another factor of two or more.

\subsubsection{Implications of Solid Wastes Scenario}

Researchers 56 have recently discussed the consequences of the enormous amounts of scrubber sludge that might be generated in Kern County based on the cumulative gross production of 6 billion barrels of oil $(550,000 \mathrm{~b} / \mathrm{d}$ for 30 yrs or $450,000 \mathrm{~b} / \mathrm{d}$ for 37 years). They concluded that production of thermal oil could generate between $9.3 \times 10^{6} \mathrm{~m}^{3}$ and $13 \times 10^{6} \mathrm{~m}^{3}$ of scrubber sludge (the range is based on evaporative losses) and that between $310 \mathrm{Ha}$ (766 acres) and $434 \mathrm{Ha}$ (1072 acres) would be required for waste disposal to a height of $3 \mathrm{~m}$. 
If the liquid wastes were converted to solids through the use of gravity thickeners, centrifuges, and vacuum filters the land requirements might range anywhere from $330 \mathrm{Ha}$ ( 815 acres), a low figure for double-alkall systems, to $633 \mathrm{Ha}$ ( 1563 acres), the high figure for limestone systems.

The use of coal fired steam generators for TEOR does not change the magnitude of the problem. Atmospheric fluidized bed combustors (AFBCs) generating steam for the extraction of 6 billion barrels of heavy oil would require between $514 \mathrm{Ha}(1270$ acres) and $718 \mathrm{Ha}$ (1773 acres) for disposal of wastes from once-through calcium-based, sorbent control systems.

Surface disposal alternatives are restricted by both Federal and State laws. Although it is possible that extraction procedure tests prescribed by EPA could result in a toxic classification for FGD or AFBC wastes, an interim rule by EPA puts scrubber wastes into the "nonhazardous" category, allowing them to be disposed of in sanitary landfills or "otherwise... in an environmentally sound manner," according to the Resources Conservation Recovery Act (RCRA), Sub. D, Sec. 4003.

In California, FGD and AFBC wastes are classified on a case-by-case basis, and some of these wastes could fall into a toxic category. 76 If so, they would then require disposal in Class I or Class II-1 sites (see ref. 76 and Section 5.8.2). Subsurface injection and waste recovery are possible alternatives, however. Ref. 57 contends that 8 injection wells with 150 gal/min capacities could handle the liquid wastes from nonregenerative FGD systems required for 6 billion barrels of gross thermal oil production. Alternatively, salt-cake recovery of sulfur salts would produce only a small amount of solid wastes requiring less than $4 \mathrm{Ha}$ of land for disposal.

\section{REFERENCES}

1. C. Braxton, et al, Potential Environmental Consequences of Tertiary Oil Recovery, Energy Resources Company, Inc., Report to EPA, July 1976. (Available from NTIS, PB-260-646.)

2. R. Beck, R. Shore, T.A. Scriven, and M. Lindquist, Potential Environmental Problems of Enhanced $0 i 1$ and Gas Recovery Techniques, Energy Resources Company, Inc., Report to EPA, EPA Report IERL-CI-706, Apri1 1980.

3. Environmental Development Plan: Enhanced O11 Recovery, DOE/EDP-0048, November 1979.

4. Environmental Readiness Document: Enhanced 011 Recovery, Commercialization Phase III Planning, DOE/ERD-0013, September 1978.

5. Environmental Compliance for Enhanced 011 Recovery, Project Planning Document, DOE, Div, of Fossil Fuel Extraction, 1979. 
6. E. Kaplan, M.H. Garrel1, E.F. Riedel, and J. Sathaye, Proceedings of Department of Energy/Office of the Environment Workshop on Enhanced 0iI Recovery: Problems, Scenarios, Risks, BNL 51406, 1980. Summary in Oil Gas J., pp. 156-64, October 5, 1981.

7. Environmental Regulations Handbook for Enhanced Oil Recovery, Bartlesville Energy Technology Center, DOE/BC/00050-15, August 1980.

8. 44 Fed. Reg. 23738 , proposed 40 C.F.R. Part 146.

9. 44 Fed. Reg. 34244, proposed 40 C.F.R. Part 122-124.

10. 44 Fed. Reg. 22069, 40 C.F.R. Part 435.

11. 44 Fed. Reg. 50766, 40 C.F.R. Part 117.

12. Enhanced Oil Recovery Model. Technical Memorandum TM/ES/79, Energy Information Administration, DOE, 1979.

13. U.S. Water Resources Council, The Nation's Water Resources 1975-2000, Vo1. 2, Part II, p. 11, December 1978.

14. A.G. Collins, Enhanced 011 Recovery Injection Waters, DOE, Bartlesville Energy Technology Center, in preparation.

15. H. M. Mittelhauser Corporation. The water requirements of selected enhanced oil recovery processes, unpublished draft report, August 1979.

16. 65th Annual Report of the State $0 i 1$ and Gas Supervisor, Publ. No. PR06, California Div. of 011 and Gas, Sacramento, 1979.

17. Nadell Chan, California Dept. of Water Resources, personal communication, February 1981.

18. A.G. Collins, Enhanced ofl recovery injection waters, in 011 Field Subsurface Injection of Water, ASTH STP 641, 1977.

19. Hal Bobb, California Div. of Oil and Gas, Bakersfield District Office, personal communication, April 6, 1981.

20. California Dept. of Water Resources, The California Water Plan Outlook in 1974, Bull. No. 160-74, November 1974.

21. California Dept. of Water Resources, Ground Water Barriers in California, Bull. No. 118-80, January 1980.

22. U.S. Water Resources Council, Analytical Data, Annual Water Supply and Use Analysis, Vol: 3. Appendix II, Table II-6, 1978.

23. U.S. Water Resources Council, Second National Assessment, Vo1. 3, p. 18, December 1978. 
24. R. Rees and A.W. Buchner, Occurrence and Quality of Ground Water in the Edwards Trinity (Plateau) Aquifer, Texas Department of Water Resources, September 1980.

25. Texas Water Development Board, Six State High Plains - Ogallala Aquifer Area Study, Working Paper, Task A-2.6, Part III, July 10, 1980.

26. Michael Rector, Consulting Geologist, Bakersfield, CA, personal communication, April 1981 .

27. Bil1 Hoffman, Texas Water Development Board, personal communication, Apri1 1981.

28. EPA, The Report to Congress, Waste Disposal Practices and their Effects on Ground Water, Office of Water Supply, Office of Solid Waste Management Program, January 1977.

29. EPA, Planning Workshops to Develop Recommendations for a Groundwater Protection Strategy, Appendices, June 1980.

30. The Migration of Petroleum Products in Soil and Groundwater, Am. Pet. Inst. Pub1. 4149, December 1972.

31. Water Research Assoc., Ground Water Pollution - A Working Conference, Vol. I, p. 297, Medmenham - Marlow, England, September 1972.

32. Peter Hepple (Ed), The Joint Problems of the Oil and Water Industries, Proceedings of Symposium 18-20 January 1967, The Institute of Petroleum, London, 1967.

33. EPA, Methodology to Evaluate the Potential for Groundwater Contamination from Geothermal Fluid Releases, Industrial Environmental Research Laboratory, EPA-600/7-80-117, 1980.

34. G. Rittenhouse, R.B. Fulton, R.J. Grabosushi, and J.L. Bernard, Minor elements in oilfield waters, Chem. Geol., 4, 189-209.

35. A.G. Collins, Saline Groundwaters Produced with 011 and Gas, EPA-660/2-74-010, 1974 .

36. A.G. Collins, Geochemistry of Oilfield Waters, Elsevier Scientific Publishing Company, New York, 1975.

37. Office of Technology Assessment, U.S. Congress, Enhanced 0i1 Recovery Potential in the United States, January 1978, U.S. Government Printing office, 052-003-00503-4.

38. E. Silvestro and A. Desmarias, Toxicity of Chemical Compounds Used for Enhanced 0il Recovery, Energy Resources Co., Inc., report to Bartlesville Energy Technology Center, DOE/BC/10014-5, 1980. 
53. EPA, 1979 Industrial Boiler FGD Survey, EPA-600/7-79-0676, 1979.

54. K. Yeager, Technical implication of particulate regulations, in Proc. of EPRI Topica1 Conference: Focus on Particulates, EPRI P-80-2-LD, June 1980. Limited Distribution.

55. State of California, Air Resources Board, Kern County New Source Review Rules, Rule 210.1, Standard for Authority to Construct, September 12, 1979.

56. D.W. Layton, and J.I. Daniels, Waste management technologies for byproducts of sulfur dioxide abatement associated with heavy oil recovery, Draft, Lawrence Livermore National Laboratory, submitted to DOE.

57. California Air Pollution Control Offices Association and California Air Resources Board Committee Rule for the Siting of New and Modified Stationary Sources in California, Draft, October 30, 1981.

58. C.K. Grantham and J.P. Sloan, Toxicity study of drilling fluid chemicals on aquatic life, in Conducting Conferences on Environmental Aspects of Chemicals Used in Various Industrial Operations, Environmental, Aspects of Chemical Use in Well-Drilling Operations, EPA-560/1-75-004, 1975.

59. J.P. Simpson, Drilling fluid principles and operations, Ibid.

60. S.Y. Chiu et al., Problems Associated with Solid Wastes from Energy Systems, ANL/EES-TM-118, 1980 .

61. A.G. Collins, Chemical applications in ofl- and gas-well drilling and completion operations, in Conducting Conferences on Environmental Aspects of Chemicals Used in Various Industrial Operations, Environmental Aspects of Chemical Use in Well-Drilling Operations, EPA-560/1-75-004, 1975.

62. T.J. Robichaux, Bactericides used in drilling and completion operations, Ibid.

63. R.P. Peters, Techniques of Shallow Well Drilling, Ibid.

64. API Bulletin on Drilling. Fluids Processing Equipment, American Petroleum Institute, Dallas, 197.4 .

65. R.B. Allred, The handling and treating of water-based drilling muds, in Conducting Conferences on Environmental Aspects of Chemicals Used in Various Industrial Cperations, Environment Aspects of Chemical Use in Wel1-Drilling Operations, EPA-560/1-7.5-004, 1975.

66. R.W. Miller and S. Honarvar, Effect of drtlling fluid components mixtures on plants and solis, Ibid.. 
39. EPA, Water supply - wastewater treatment coordination study, Contract \#68-01-5033, August 1979.

40. G. Mulligan, Texas Railroad Commission, personal communication, April 1981 .

41. Robert Reid, California Div, of 011 and Gas, Sacramento, personal communication, February 1981.

42. Charles L. Kleeman, Water Supply Branch, EPA Philadelphia, personal communication, May 7, 1981.

43. John T. Egan, Water Supply Branch, EPA Region III, Philadelphia, letter to Bruce Crawford, HUD, Pittsburgh, April 11, 1980.

44. Edgerley Ryckman, Tomlinson Associates, St. Louis, Air Pollutant Emissions Testing Report, Oil Field Steam Generators, report written for the Santa Fe Energy Corp., RETA-3216, Ju1y 1977.

45. H.J. Tabak, Determination of Air Pollutant Emission Factors for Thermal Tertiary Oil Recovery Operations in California, Vol. I, KVB Inc., prepared for State of California, Air Resources Board, May 1980.

46. EPA, Compilation of Air Pollutant Emission Factors, Pub1. AP-42, 3rd Ed. with Suppl., Research Triangle Park, NC, 1977.

47. J.S. Davis, W.W. Young, and C.J. Lyons, Use of solid fuel possible for field steam generation, 0i1 Gas J., pp. 129-33, June 8, 1981.

48. 65th Annual Report of the State $0 i 1$ and Gas Supervisor, Pub1. No. PR06 California Div. of Oil and Gas, 1980 .

49. California Air Resources Board, Status of $\mathrm{NO}_{\mathrm{x}}$ Control for Steam Generators and Availability of $\mathrm{NO}_{x}$ Trade-offs in Kern County, Staff report, November 28, 1979.

50. California Air Resources Board, Public Hearing to Consider Amendments to the Rules and Regulations of the Kern County Air Pollution Control District-Amendments to Rule 210.1, Standard for Authority to Construct, and Addition of Rule 425, Relating to Retrofit Control for Emissions of Oxides of Nitrogen from Oil Field Steam Generators, February 4, 1980 (a1so attachment IX-C, Staff Conclusions).

51. J.M. Robinson, $\mathrm{NO}_{\mathbf{x}}$ control by thermal DeNO $\mathrm{x}_{\mathrm{x}}$ process and tertiary oil recovery steam generator, Air Po11. Control Assoc., Paper No. 79-33.4, presented at Cincinnati, June 24-28, 1979.

52. J.R. Hoover, Special Report, EPA Industrial Boiler FGD Survey - 1979, by Radian Corporation for EPA, EPA-600/7-81-081 (4/81). 
67. R.H. Weir and B. Moore, Acute Toxicity of Well-Drilling Muds to Rainbow Trent, Salmo Gairdneri (Richardson), Ibid.

68. L.R. Louden and R.E. McGlothlin, Waste water base drilling fluid disposal, Ibid.

69. EPA, Questions and Answers on Hazardous Waste Regulations, Office of Water and Waste Management, SW-853, 1980.

70. A.N. Patkar, S.P. Kothari, and J.D. Tuttle, An Evaluation of Flue Gas Desulfirzation Process for Application to California 0il Field, Final Report, PEDCO Env. Inc. for DOE/Fossil Energy, San Francisco office, $\overline{\mathrm{DOE} / \mathrm{ET}} / 1$ 2088-1, April 1980.

71. The Aerospace Corporation, Fluidized-bed combustion, in Energy Technologies and the Environment, Environmental Handbook, DOE/EP-0026, pp. 61-80, 1981.

72. Steam Its Generation and Use, pp. 5-9, Babcock and Wilcox, New York, 1978.

73. DOE, Fluidized-bed combustion, in Environmental Data Energy Technology Characterizations, Coal, DOE/EV-0074, pp. 6-1 to 6-10, 1980 .

74. Code of Federa1 Regulations, 4OCRF261.4, GPO, Washington, DC, 1980.

75. A.L. Franks, Waste Discharge Requirements for Nonsewerable Waste Disposal to Land, California State Water Resources Control Board, July 1980.

76. California Department of Health Services, California Assessment Manual for Hazardous Wastes, Sacramento, 1981.

77. Oklahoma State Department of Health, Rules and Regulations for Industrial Waste Management, ODH Bu11. 非525, Revised 5/19/79. 
0 -
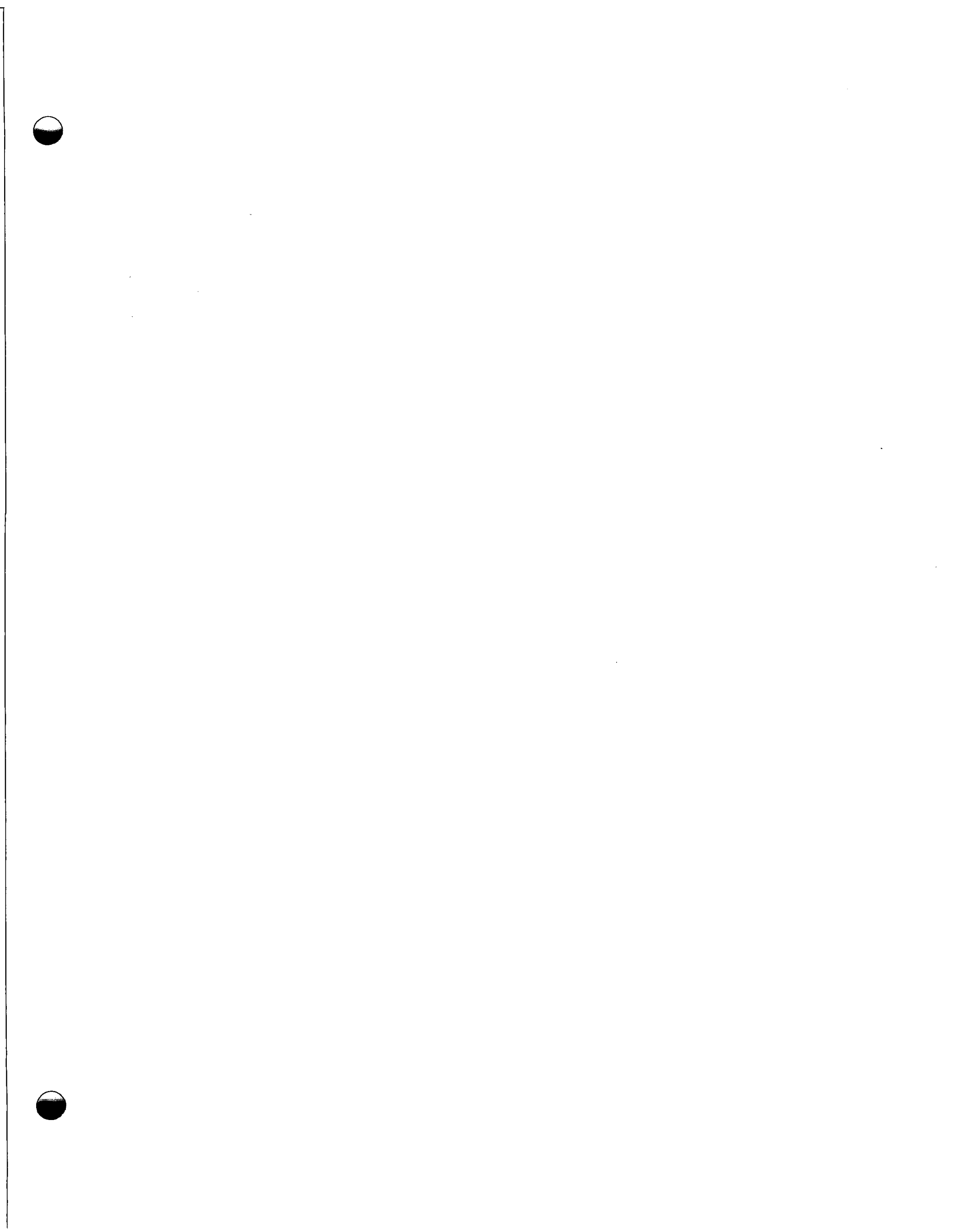


\subsection{LAND USE IN TERTIARY RECOVERY}

This chapter discusses land use and land requirements for enhanced oil recovery. Abandonment and site restoration are described briefly.

Exploitation of any petroleum resource affects the existing land use during the lifetime of the project, which can be as long as 50 years, from discovery through tertiary operations. Different stages within the project have different land use requirements. In fieldwide operations, tertiary recovery uses more land than secondary, and secondary recovery uses more land than primary. Within tertiary recovery, thermal and chemical methods use the largest amounts of land while miscible gas methods use the least.

For individual wells the amount of land use area is fixed by the well spacing. For example, each well site must have road and pipeline access. Primary operations typically require pumping units for the producing wells and electrical power lines. Waterflooding operations require water treating and injection facilities. Chemical flooding operations require chemical mixing and handling facilities and even larger water treatment facilities. Thermal flooding operations require efther steam generating facilities or air compressors. Miscible gas flooding operations require gas compressors and large-scale gas transmlssion lines (from the gas source to the field).

\subsection{LAND REQUIREMENTS}

The total land needs are dependent on a number of factors. The three most important are well spacing, well depth, and the type of recovery operation. Topography, well spacing, and depth are independent of the recovery operation, 1.e., of the field producing ofl or gas. Each well that is drilled requires a certain land area that is level and cleared, a road to reach the well site, and product transmission pipelines to a central processing station. A shallow well requires less than an acre for a drill site, while a deeper well may need 2 to 5 acres. Once the wells have been drilled, the land need is much smaller (as small as a few hundred square feet or as large as an acre per well). Table 6.1 contains a comparison of some general land usage requirements for different recovery techniques.

\subsubsection{Abandonment}

Site restoration is an important last step in the life of any petroleum field. Certain procedures such as plugging and marking of a well are covered by the state or federal permitting processes. Other procedures can be stated within the surface owner's lease and thus are negotiable.

In general, a work-over $\mathrm{rlg}$. will be-brought in to remove the well casing. Then a cement slurry will be pumped down the hole, and it will be plugged, as mandated by state and/or federal regulations, normally from the bottom to the top with cement for a shallow well. Both of these procedures w111 require the intermittent use of diesel motors. However, both procedures 
Table 6.1

Land Needs vs Recovery Techniques

(Al) based on a square field of 640 acres)

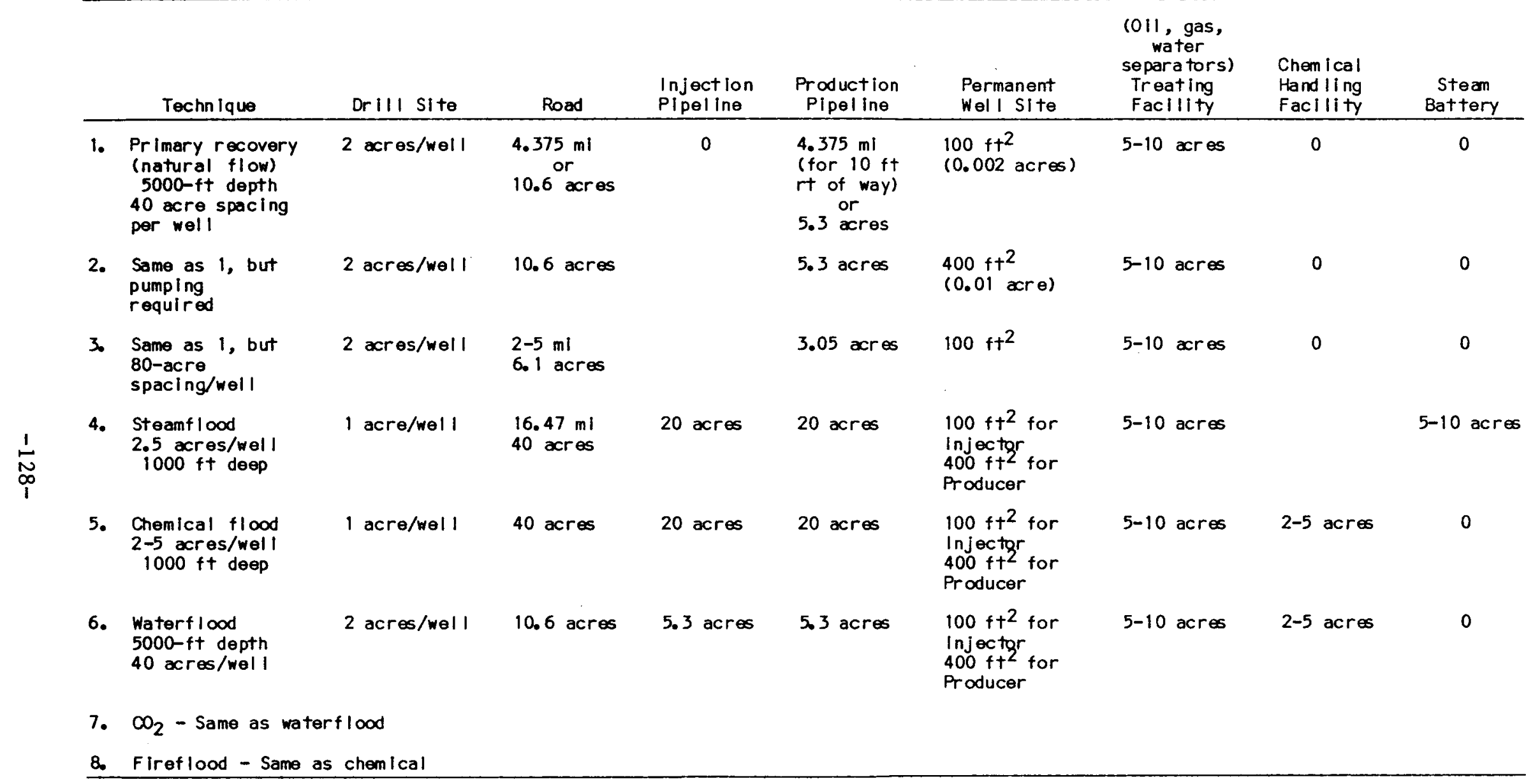


are of very short duration and thus, the overall environmental impacts are minimal.

All of the surface facilities will be dismantled and removed. This will require personnel, lifting equipment, and large trucks. These tasks will last a short time and have minimal impacts.

The final procedure is either to recontour and reseed all disturbed land (roads, pipelines, and drill pads) back to their original conditions or to leave the land as specified by the lease agreement. If the landowner desires, the site, including roads and drill pad, may be left for his use after it is cleaned. Recontouring and reseeding activities will require equipment with diesel motors similar to those used in the construction activities and should likewise result in no measurable air quality impact. Seeding should reduce erosion, have a positive environmental effect, and encourage the local fauna and flora population to return to normal. 
?<smiles>Ic1ccccc1</smiles>

$$
0
$$

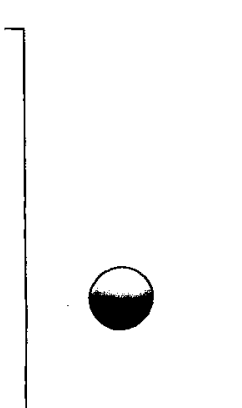

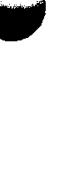
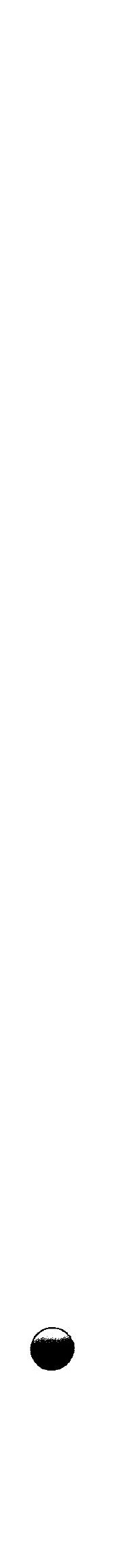

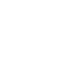$$
\text { (⿸丆口 }
$$
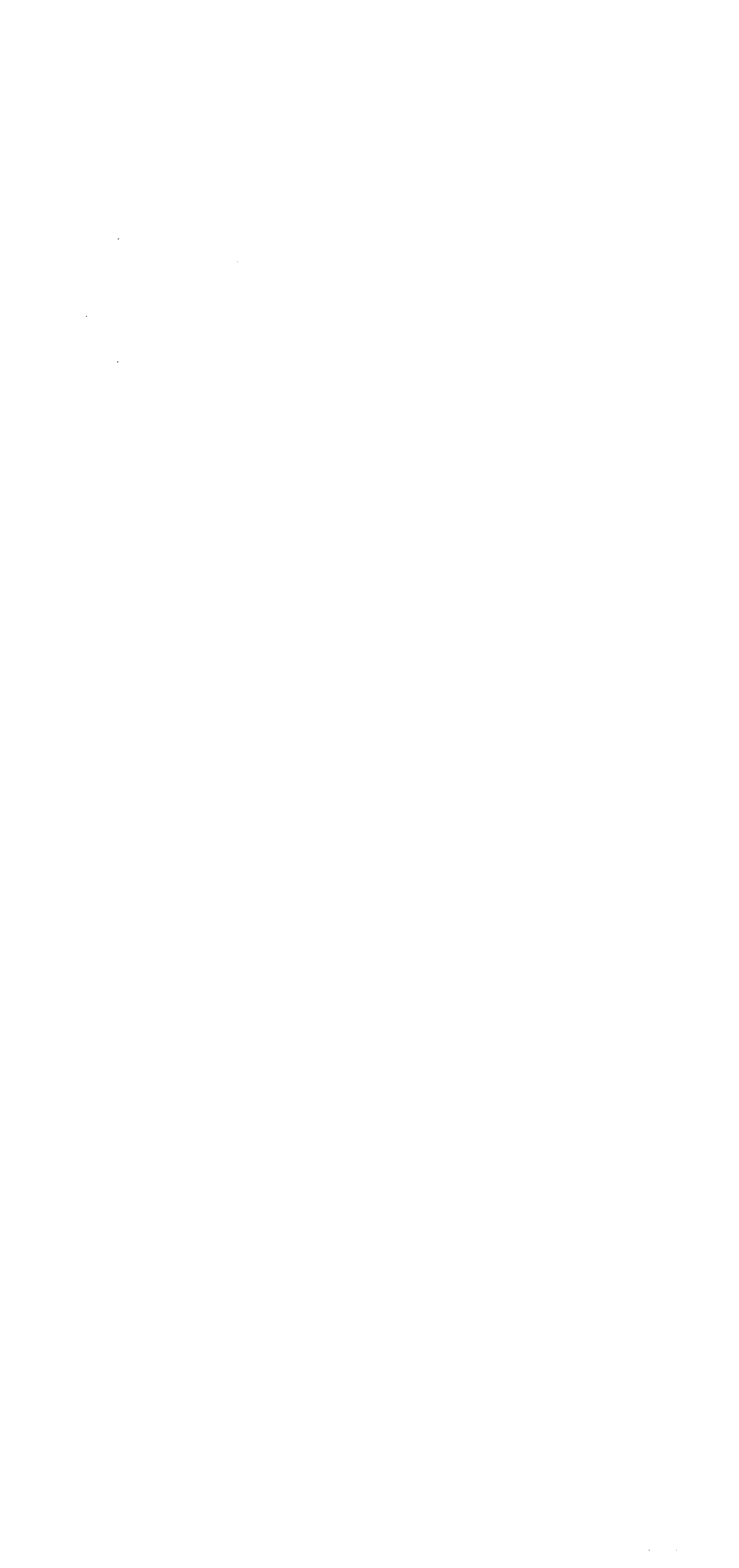


\section{CONCLUSIONS}

In this report, we conclude that enhanced oil recovery (EOR) is an excellent source of oil, and that, from an environmental standpoint, tertiary oil as an energy source is preferable in many respects to shale oil, coal, and synfuels. Alternative sources of oil such as syncrude, exploration, and primary production could cause more environmental damage than increased enhanced oil recovery.

Certain environmental issues may constrain future EOR in specific regions, however. These issues include air quality, solid waste disposal, water avallability, and aquifer contamination, and we summarize below the material found in the body of our report on those subjects.

Because steam flood and steam soak are the dominant EOR technologies in California and because they will remain so for at least the next two or three decades, alr quality and solid waste disposal are paramount concerns in that region. Air pollution control technologies, $\mathrm{SO}_{\mathrm{x}}$ and $\mathrm{NO}_{\mathrm{x}}$ controls in particular, will play a crucial role in any additional thermal EOR projects in California; this is especially true in Kern County for which the New Source Review regulations issued by the California Air Resources Board in September 1979 state, "Any emissions from new sources must be offset by $100 \%$."

With scrubbers and $\mathrm{NO}_{x}$ controls in place on steam generators in thermal fields, solid waste disposal becomes a primary problem. Currently, the murky distinction between hazardous and nonhazardous waste clouds the whole issue of scrubber waste disposal for EOR in Southern California, and the lack of large, conveniently accessible waste disposal areas compounds the problem.

Water availability must be considered carefully wherever the water required and the water consumed are of the same magnitude, e.g., in micellarpolymer, polymer, or alkaline floods. Furthermore, competing regional uses for water, drought situations, and scarcity of surface or ground water which are low in total dissolved solids (TDS) will impede some EOR projects. In one of the scenarios in this report, we arbitrarily assumed that $25 \%$ of the water demand for EOR would be met by freshwater and found 18 counties in the nation where demand would exceed $1.78 \mathrm{Mgd}$. Groundwater overdrafts could be a problem in 11 of those counties where withdrawals already represent $85 \%$ of EOR water demanded in our projections.

Groundwater contamination due to oil production is recorded in all oflproducing states. Unfortunately, most of the information is anecdotal, and neither verification nor quantification is possible in most cases. All states except Montana have now applied for primacy in administration of Underground Injection Control (UIC) programs for Class II wells, and all states have some regulations for underground injection of brines and injection of fluids for ofl and gas production. Unhappily, enthusiasm for enforcement varies and so does the strictness of regulation in the various states. A lack of wlllingness to conslder risks of aquifer contamination has been found in states where production- or development-orfented departments are in charge of UIC programs. This is unfortunate for obvious reasons. 
Although the overall risk of contamination from increased national EOR appears small, some incidents of local contamination are inevitable, and the failure in some states to face the problems of spills and leakages (from brine disposal wells, for example) could have dire consequences for those who depend on nearby aquifers. There is no free market in risk for those whose aquifers are contaminated, and even the costly rehabilitation of such aquifers may be impossible in less than several decades.

Lesser environmental issues, such as occupational health and safety and land disturbance, should not hinder EOR operations in most cases. Although some EOR chemicals are hazardous and require special handling and disposal, the oil industry is addressing these problems through technology transfer, and employee unions are pursuing worker safety as well. Enhanced recovery sites, reworked following development for primary and secondary production, usually experience only small ecological disturbances due to the clearing of additional roads, installation of new pipes, hauling of equipment, and recompletion of wells. These disturbances are relatively small compared to those found in petroleum exploration and in development of fields for primary production. Land disturbances will be greater than expected for gasinjection EOR, where extensive pipelines and auxiliary facilities will be required between gas sources and injection wells.

The data in this report suggest that more time should be spent in the assembly of a complete and consistent data base for all U.S. fields for which EOR is planned or in which tertiary production is taking place. Only by projecting or estimating fieldwise tertiary production versus time will it be possible to accurately project or estimate water and chemical requirements, volumes of brine for disposal, air emissions, and scrubber wastes. By combining data from industry, government (e.g., Energy Information Agency; the Bartlesville Energy Technology Center), and other sources (e.g., Petroleum Data System), an accurate project-by-project scenario could be developed. Where obvious environmental problems are indicated for given projects, modifications could be made, e.g., increased recycling of project water or timing the development of fields according to overall regional water development plans.

Offshore and Alaskan EOR are already on the horizon. It is imperative that studies of these areas and their particular environmental problems be initiated soon.

As with every other energy technology, EOR has its environmental risks. However, most of the problems associated with the technologies, projects, and fields in the scenario used herein appear to be solvable by proper planning, by responsible regulations and enforcement, and by best professional engineering applications by project operators themselves. 
The problem of groundwater contamination is not new, inherent only to EOR technologies, but has existed since oil production began. Aquifer contamination resulting from petroleum production can occur in one of three ways :

- leaching from ground surface; for example from a disposal site or surface spill

- direct release into the aquifer from a well casing failure during injection, production, or disposal

- migration from injection zone to aquifer through fissures and cracks

The likelihood of groundwater contamination resulting from increased EOR production is expected to increase for several reasons. First, most tertiary production methodologies recover oil by injecting various fluids, gases, and/or chemicals into the oil-bearing strata. Although federal and state regulations have been developed to ensure the proper use of new injection wells, enforcement of these regulations will be very difficult. Strict compliance is necessary to prevent serious threats to groundwater quality. Second, there is concern because of the large numbers of injection wells for which the possibility of casing deterioration increases with age. Third, many older fields have abandoned and improperly plugged wells, representing passageways through which fluids from the EOR reservoir could migrate into aquifers. Records of the locations and conditions of these improperly abandoned wells have not always been kept. In addition, the chemicals used in some EOR methods include certain toxic substances. Most EOR chemicals will remain in the reservoir. The mechanisms and rates of decay as well as degradation products of these chemicals are not fully known. The use of these chemicals not previously tested in oil production technologies introduces a new set of potential pollutants.

Disposal of brines, chemicals, and drilling muds also presents potential risks to groundwater quality. Petroleum production wastes disposed of in unlined pits have contaminated aquifers in the past, and several states now require disposal sites for petroleum wastes to be lined and bermed, and to contain leachate collection systems. Produced brine is commonly disposed of by underground injection, either to the oil-bearing strata or to other subsurface formations. Typically, these disposal wells are old production wells converted after oil recovery was no longer feasible from the reservoir.l The ratio of brine-to-oil produced from EOR increases with time, further compounding this brine disposal problem.

Several mathematical models have been developed in an effort to predict the movement of pollutants in an aquifer. Bear ${ }^{2}$ derives the equation describing the transport of contaminants in an advection-dispersion model which also considers adsorption and decay of the pollutant. The application of this methodology assumes the aquifer is vertically mixed and has uniform steady flow in the longitudinal direction. The differential equation describing this model is 


$$
R_{d} \frac{\partial c}{\partial t}=D_{x} \frac{\partial^{2} c}{\partial x^{2}}+D_{y} \frac{\partial^{2} c}{\partial y^{2}}+D_{z} \frac{\partial^{2} c}{\partial z^{2}}-v \frac{\partial c}{\partial x}-\lambda R_{d} c
$$

where

$$
\begin{aligned}
c & =\text { concentration of the pollutant in the aquifer, } \\
t & =\text { time, } \\
\mathrm{R}_{\mathrm{d}} & =\text { the retardation factor, } 1+\mathrm{k} / \epsilon \\
\mathrm{k} & =\text { adsorption coefficient of the pollutant, } \\
\epsilon & =\text { fractional void volume, } \\
\lambda & =\text { first-order decay constant of the pollutant, } \\
\mathrm{D}_{\mathrm{x}}, \mathrm{D}_{\mathrm{y}}, \mathrm{D}_{\mathrm{z}} & =\text { dispersion coefficents in the } \mathrm{x}, \mathrm{y}, \mathrm{z} \text { directions, } \\
\mathrm{V} & =\text { velocity in the direction of flow. }
\end{aligned}
$$

The solution to Eq. (1) depends on the time duration of pollutant release into the aquifer. A short-term release (i.e., slug) is one that occurs over a relatively short time period, e.g., a surface spill, leakage from a broken pipe or valve, short-term leaching from a disposal site, or a leaking well which is shut down soon after its discovery.

The solution of $\mathrm{Eq}$. (1) for a slug release is obtained by factoring out the retardation factor and by integrating in two dimensions 3,4

$$
c(x, y, t)=\frac{1}{R_{d}} \frac{m^{\prime}}{4 \pi p t\left(D_{x} D_{y}\right)^{1 / 2}} \exp \left[-\frac{(x-V t)^{2}}{4 D_{x} t}-\frac{y^{2}}{4 D_{y} t}-\lambda t\right],
$$

where

$$
\begin{aligned}
\mathrm{m}^{\prime}= & \text { total mass of pollutant injected into the aquifer per unit } \\
& \text { thickness of the aquifer, } \\
\mathrm{p}= & \text { porosity of the aquifer. }
\end{aligned}
$$

The concentration of a substance from a continuous release injected at a constant rate into an aquifer is given by ${ }^{3}$

$$
c(x, y, t,)=\frac{f_{m}^{\prime} e^{x / B}}{4 \pi p\left(D_{x} D_{y}\right)^{1 / 2}} w\left(u, \frac{r}{B}\right),
$$

where

$$
\begin{aligned}
f_{m}^{\prime}= & \text { mass flux injection rate of the pollutant, injected per unit } \\
& \text { aquifer thickness; }=\mathrm{qc}_{\mathrm{O}}, \\
\mathrm{q}= & \text { volumetric injection rate per unit thickness of aquifer, } \\
\mathrm{C}_{\mathrm{O}}= & \text { initial concentration of pollutant, } \\
\mathrm{B}= & 2 \mathrm{D}_{\mathrm{x}} / \mathrm{V} \\
\gamma & =1+2 \mathrm{~B} \lambda / \mathrm{V} \\
\mathrm{r} & =\text { radial distance from the source; }
\end{aligned}
$$




$$
\begin{aligned}
& =\left[\left(\mathrm{x}^{2}+\frac{\mathrm{D}_{\mathrm{x}}}{\mathrm{D}_{\mathrm{y}}} \mathrm{y}^{2}\right) \gamma\right]^{1 / 2}, \\
\mathrm{u} & =\frac{\mathrm{r}^{2}}{4 \gamma \mathrm{D}_{\mathrm{x}} \mathrm{t}}, \\
\mathrm{W}\left(\mathrm{u}, \frac{\mathrm{r}}{\mathrm{B}}\right) & =\text { we11 function; } \\
& =\int_{\mu}^{\infty} \frac{1}{\theta} \exp -\left(\theta+\frac{\mathrm{b}^{2}}{4 \theta}\right) \mathrm{d} \theta \quad ; \text { and } \mathrm{b}=\mathrm{r} / \mathrm{B} .
\end{aligned}
$$

Hantush5,6 first applied the well function when analyzing the problem of pumping a fully penetrating well at a constant rate from an infinitely leaky aquifer. Values of the well function, calculated by numerical integration and infinite series representations, are given ${ }^{5}$ for ratios of $r / B<9$. For large ratios of $\mathrm{r} / \mathrm{B}$, the well function can be approximated by the Laplace Method as

$$
\mathrm{W}\left(\mathrm{u}, \frac{\mathrm{r}}{\mathrm{B}}\right) \cong\left(\frac{\pi \mathrm{B}}{2 \mathrm{r}}\right)^{1 / 2} \exp \left(\frac{-r}{B}\right) \operatorname{erfc}-\left(\frac{(r / B)-2 u}{2 u^{1 / 2}}\right),
$$

where erfc is the complementary error function. This approximation has been shown to be accurate to within $1 \%$ for values of $r / B>10$.

Eventually, the pollutant concentration from a continuous release will reach a steady state in which the rate of injection equals the rate of dispersion into the aquifer. The value of $u$ in the well function approaches zero as time increases, causing the well function approximation to reach a limit; it can then be replaced by a modified Bessel function $\mathrm{K}_{\mathrm{o}}$ :

$$
W(0, r / B)=2 K_{0}(r / B) \text {, }
$$

where

$$
\mathrm{K}_{\mathrm{o}}(\mathrm{r} / \mathrm{B}) \cong\left(\frac{\pi \mathrm{B}}{2 \mathrm{r}}\right)^{1 / 2}\left(\mathrm{e}^{-\mathrm{r} / \mathrm{B}}\right)
$$

The steady state concentration can be computed after making these substitutions in Eq. (3).

Two example calculations are presented for hypothetical releases of brine using the method above. Oil field brines have total dissolved solids (TDS) ranging from less than $10,000 \mathrm{mg} / \mathrm{l}$. to over $300,000 \mathrm{mg} / \mathrm{l}$. Generally, sodium chloride constitutes $80 \%$ or more of these TDS. U.S. drinking water standards recommend a limit for chlorides of $250 \mathrm{mg} / \mathrm{l}$ in public water supplies. ${ }^{7}$ Studies from Australia and South Africa helped to develop recommended water quality tolerances of salinity for livestock. These proposed levels are given in Table 1. Concentrations of dissolved solids in water can also 
Table 1

\begin{tabular}{cc} 
Proposed Water Quality Tolerances of Dissolved Solids for Livestock 8 \\
\hline Animal & $\begin{array}{c}\text { Threshold Salinity } \\
\text { Concentration* (TDS mg/l) }\end{array}$ \\
\hline Poultry & 2,860 \\
Swine & 4,290 \\
Horses & 6,435 \\
Dairy cattle & 7,150 \\
Beef cattle & 10,000 \\
Sheep (adult, dry) & 12,000 \\
\hline *Total salts, mainly NaCl. & \\
\hline
\end{tabular}

Table 2

Suggested Total Dissolved Solids Levels $(\mathrm{mg} / \mathrm{l})$ for Irrigation Waters 8

Water for which no detrimental effects will usually be noticed

$<500$

Water which can have detrimental effects on sensitive crops

$500-1000$

Water that can adversely affect many crops and which

requires careful management practices

$1000-2000$

Water that can be used for tolerant plants on permeable

soils with careful management practices

$2000-5000$

affect its use for irrigation. Table 2 describes suggested salinity levels for irrigation purposes. In addition, the U.S. Environmental Protection Agency has recently proposed a classification scheme for groundwater.9 Aquifers with less than $10,000 \mathrm{mg} / \ell$ concentrations of dissolved.solids are classifled as freshwater and are not to be degraded. This limit has been selected to protect groundwater resources for the future. The methodology presented in this appendix could also be used to evaluate aquifer degradation from oil or chemical spills. However, the paucity of data on absorption and biodegradation for these substances makes this application difficult.

The DOE-sponsored North Burbank micellar-polymer flood demonstration project was chosen to illustrate applications of Eqs. (2) and (3). This ofl field is located in Osage County in northeastern Oklahoma. The soil in the area is of the Vanoss Group, consisting of layers of limestone, shale, and fine-grained sandstone. 10 Minor aquifers, including shale, sandstone, and thin alluvium deposits, are also present in Osage County. Records of freshwater wells drilled within a few miles of the oil field provide additional data on the geologic characteristics and quality of these aquifers.11,12 
Table 3

Range of Values of Porosity 13

$\mathrm{p}(\%)$

\begin{tabular}{ll}
\hline Unconsolidated deposits & \\
Gravel & $25-40$ \\
Sand & $25-50$ \\
Silt & $35-50$ \\
Clay & $40-70$ \\
Rocks & \\
Fractured basalt & $5-50$ \\
Karst limestone & $5-50$ \\
Sandstone & $5-30$ \\
Limestone, dolomite & $0-20$ \\
Shale & $0-10$ \\
Fractured crystalline rock & $0-10$ \\
Dense crystalline rock & $0-5$ \\
\hline
\end{tabular}

EXAMPLE 1: SHORT-TERM RELEASE

Brine with a chlorides concentration of $50,000 \mathrm{mg} / \ell$ is placed into a small disposal pit overlying a shallow aquifer. The pit has a surface area of 1024 square meters and a depth of 4 meters. The distance from the bottom of the pit to the top of the aquifer is 10 meters. The soil, consisting mainly of Red Eagle Limestone, is assumed to have a porosity of $35 \%$ which is consistent with values given in Table 3 .

The downward velocity, $V$, of fluid through the soll is assumed to be 0.1 meters per day $(\mathrm{m} / \mathrm{d})$. The fractional vold volume, $\epsilon$, is computed from the soil porosity to be

$$
\epsilon=\frac{p}{1-p}=0.54
$$

The Darcy velocity in the downward direction can be approximated by

$$
\mathrm{V}_{\mathrm{D}} \cong \mathrm{v}_{\epsilon}=0.054 \mathrm{~m} / \mathrm{d}
$$

The volumetric flow rate of liquid through the soll below the disposal pit can be calculated from the Darcy velocity and the area of the pit.

$$
Q=V_{D} A_{p}=55.3 \mathrm{~m}^{3} / \mathrm{d}
$$

The aquifer below the pit has a saturated thickness of 5 meters. The velocity in the aquifer is assumed to be $0.3 \mathrm{~m} / \mathrm{d}$. Dispersion coefficients, partially responsible. for mixing and spreading of pollutants in the aquifer, are sometimes determined from field studies. However, these coefficients are very difficult to obtain and values are not available at the Oklahoma site. Dispersion coefficients were assumed from the literature ${ }^{14}$ to be $D_{x}=0.93$ $\mathrm{m}^{2} / \mathrm{d}$ and $\mathrm{D}_{\mathrm{y}}=0.46 \mathrm{~m}^{2} / \mathrm{d}$. 
Table 4

Brine Concentration for Three Time Periods From Slug Release With an Initial Concentration of $50,000 \mathrm{mg} / \mathrm{l}$

\begin{tabular}{ccc}
\hline Time (days) & x Distance (meters) & Concentration (mg/l) \\
\hline 365 & 109.5 & 39,000 \\
1155 & 346.5 & 12,300 \\
1945 & 583.5 & 7,300 \\
\hline
\end{tabular}

Chloride in brine is a conservative pollutant: it does not decay $(\lambda=$ $0)$ nor does it absorb $(k=0)$. The aquifer below the pit could be contaminated if the pit liner were breached (i.e., either the clay becomes saturated or the membrane deteriorates). It would then take a relatively short time for the brine to move out of the disposal pit; consequently the contamination is treated as a slug release. The resulting brine concentration can be computed at a given location and time by Eq. (2). This equation could also be used when a well casing fails, and a slug of material is released before the well is shut in and the casing is repaired. (It should be noted that in the discussion to follow, the term brine is used synonymously with TDS and chlorides.)

The concentration of brine in the freshwater aquifer has been calculated for three different time periods and the results are shown in Figure 1 . The maximum concentration and its location directly downstream from the disposal site is presented for each time period in Table 4.

Concentrations of brine resulting from the release described in this example indicate that the freshwater level of $10,000 \mathrm{mg} / \mathrm{l}$ set by EPA can be violated by even a small release. The limit set by EPA has been exceeded at various locations for more than three years in this hypothetical example. Comparison of the concentrations in Table 4 with criteria values in Tables 1 and 2 illustrates that a release similar to this would render portions of the aquifer useless for more than five years.

\section{EXAMPLE 2: CONTINUOUS RELEASE}

Underground injection is a common disposal method for brine. As a typical example, consider $900 \mathrm{bbl} /$ day of brine with a chloride concentration of $50,000 \mathrm{mg} / \ell$ injected into a disposal wel1. The disposal well passes through an aquifer which has a saturated thickness of 5 meters, a porosity of $35 \%$, and a seepage velocity of $0.3 \mathrm{~m} / \mathrm{d}$.

Assume the well develops a small, undetected leak and that $10 \%$ of the injected flow enters the aquifer. The resulting concentration of brine in the aquifer can be calculated, using Eqs. (3) and (4). For the well function approximation to be accurate within $1 \%$, the value of the radial distance from the source $r$ must be greater than 62 meters for this aquifer system. 


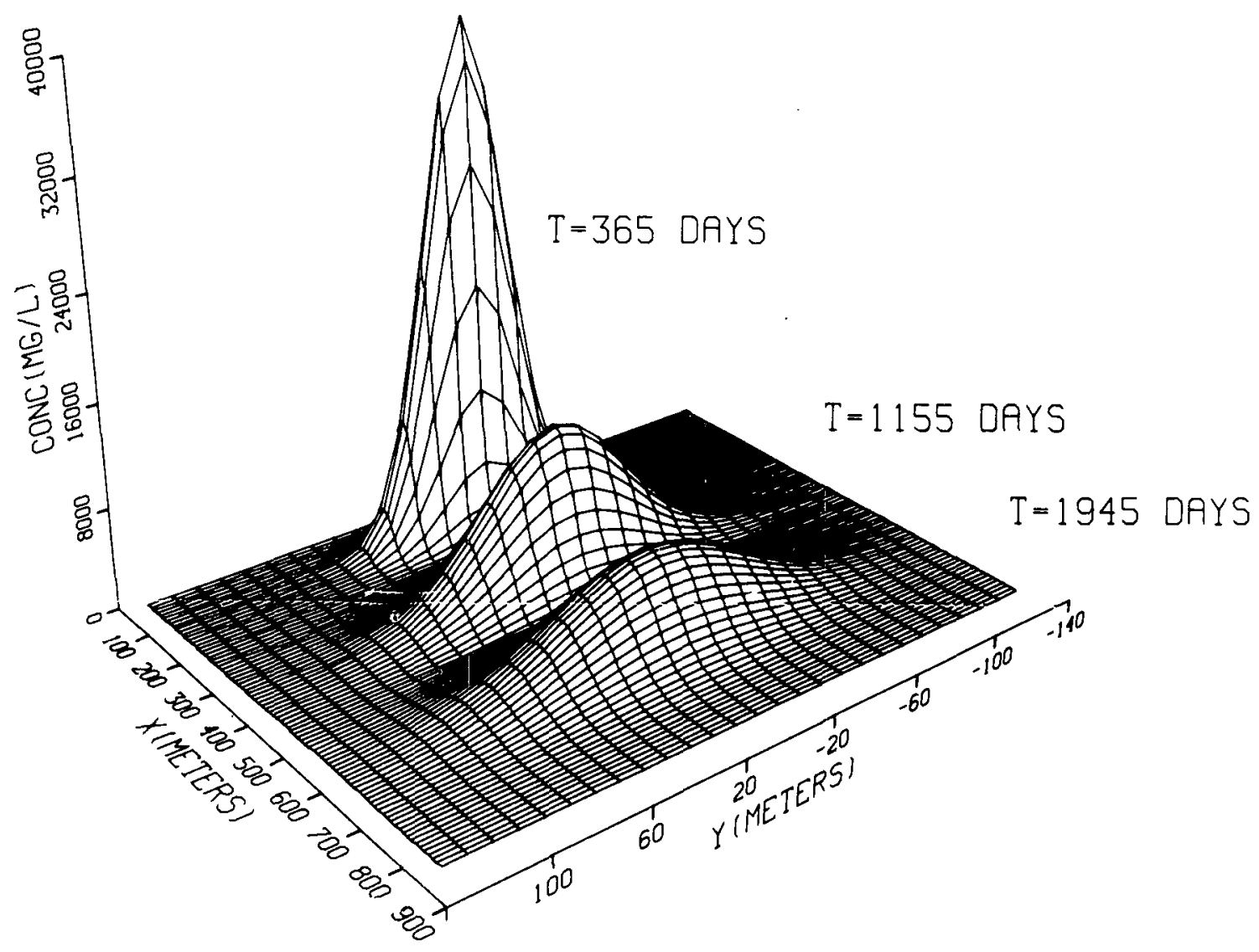

Figure 1. Brine concentration from a slug release with an initial chlorides concentration of $50,000 \mathrm{mg} / \ell$.

To evaluate the impact of the duration of the pollutant release, calculations are presented for three time periods. If the leak were to go undetected for one year, the concentration of brine 65 meters directly downstream from the well would be $37,700 \mathrm{mg} / \mathrm{l}$. There is a sharp decrease in concentration from 65 meters to 150 meters away from the injection point, as seen in Figure 2. After one year the brine concentration front (concentrations $>250 \mathrm{mg} / \ell$ ) would have traveled 180 to 190 meters from the disposal well and would have spread out transversely 20 to 25 meters on either side of the well.

A continuous release of 1095 days' ( $3 \mathrm{yr}$ ) duration produces a maximum brine concentration of $39,400 \mathrm{mg} / \mathrm{l}$ sixty-five meters directly downstream from the point of injection. The brine concentration front advances almost 400 meters from the disposal well. The concentration distribution in the aquifer at this time period is illustrated in Figure 3.

After 1945 days $(5.3 \mathrm{yr}$ ), the brine front has traveled over 800 meters longitudinally and has dispersed transversely 80 meters on elther side of the disposal well (Figure 4). The resulting brine concentration 65 meters directly downstream of the injection point is again $39,400 \mathrm{mg} / \mathrm{l}$, indicating that steady state conditions have been reached at that distance. 


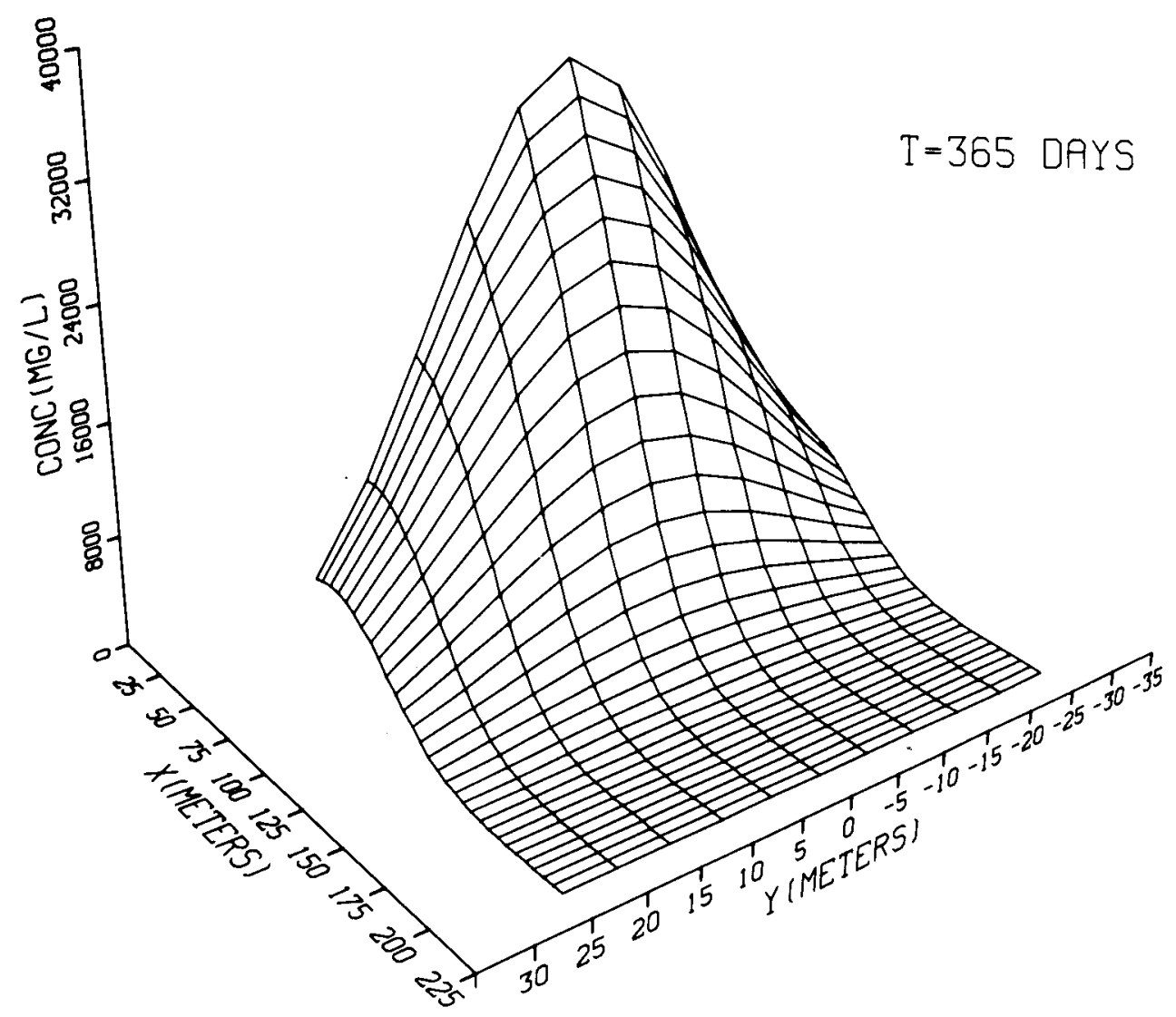

Figure 2. Brine concentration 365 days after a continuous release of chlorides directly into the aquifer.

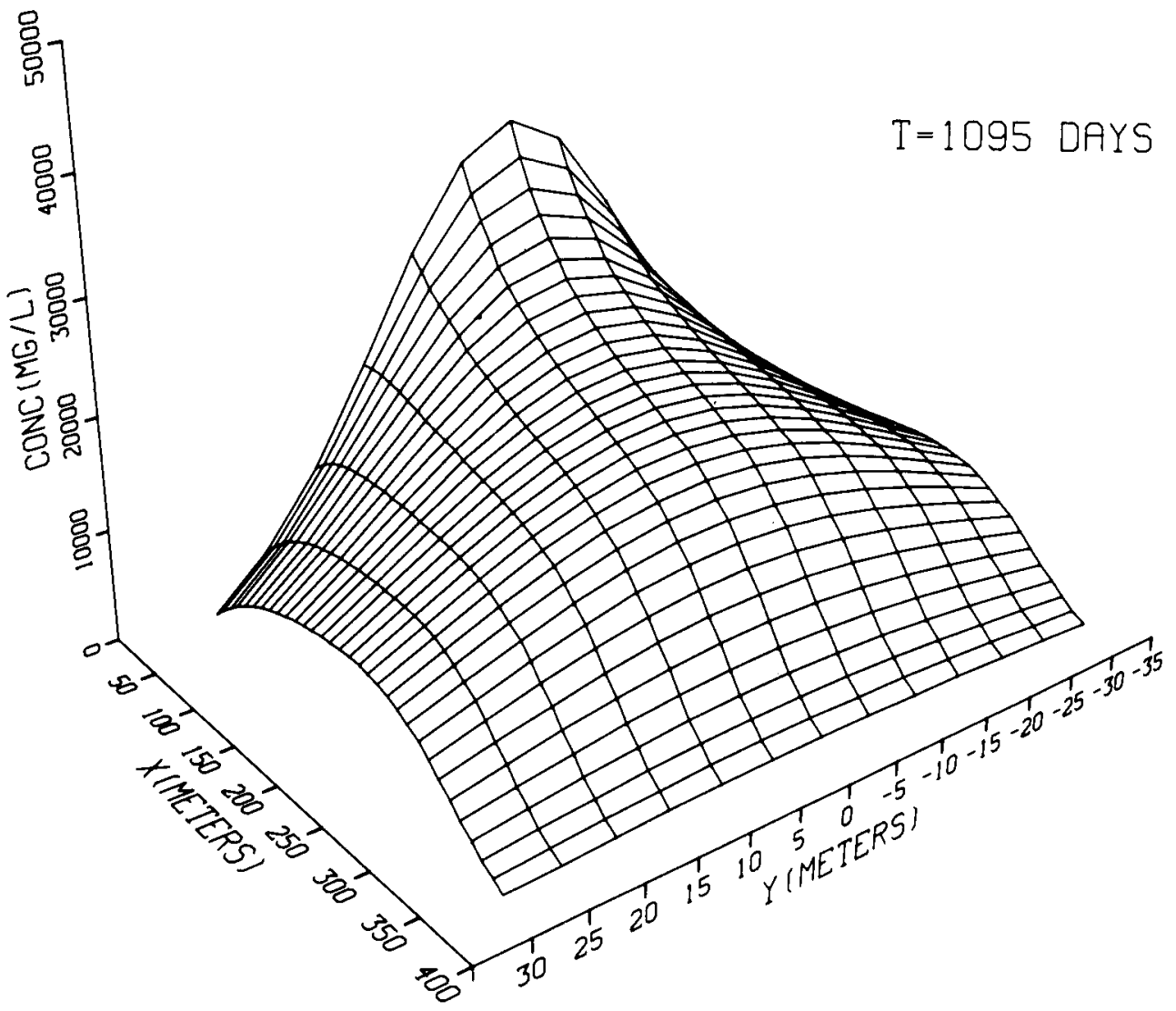

Figure 3. Brine concentration 1095 days after a continuous release directly into the aquifer. 


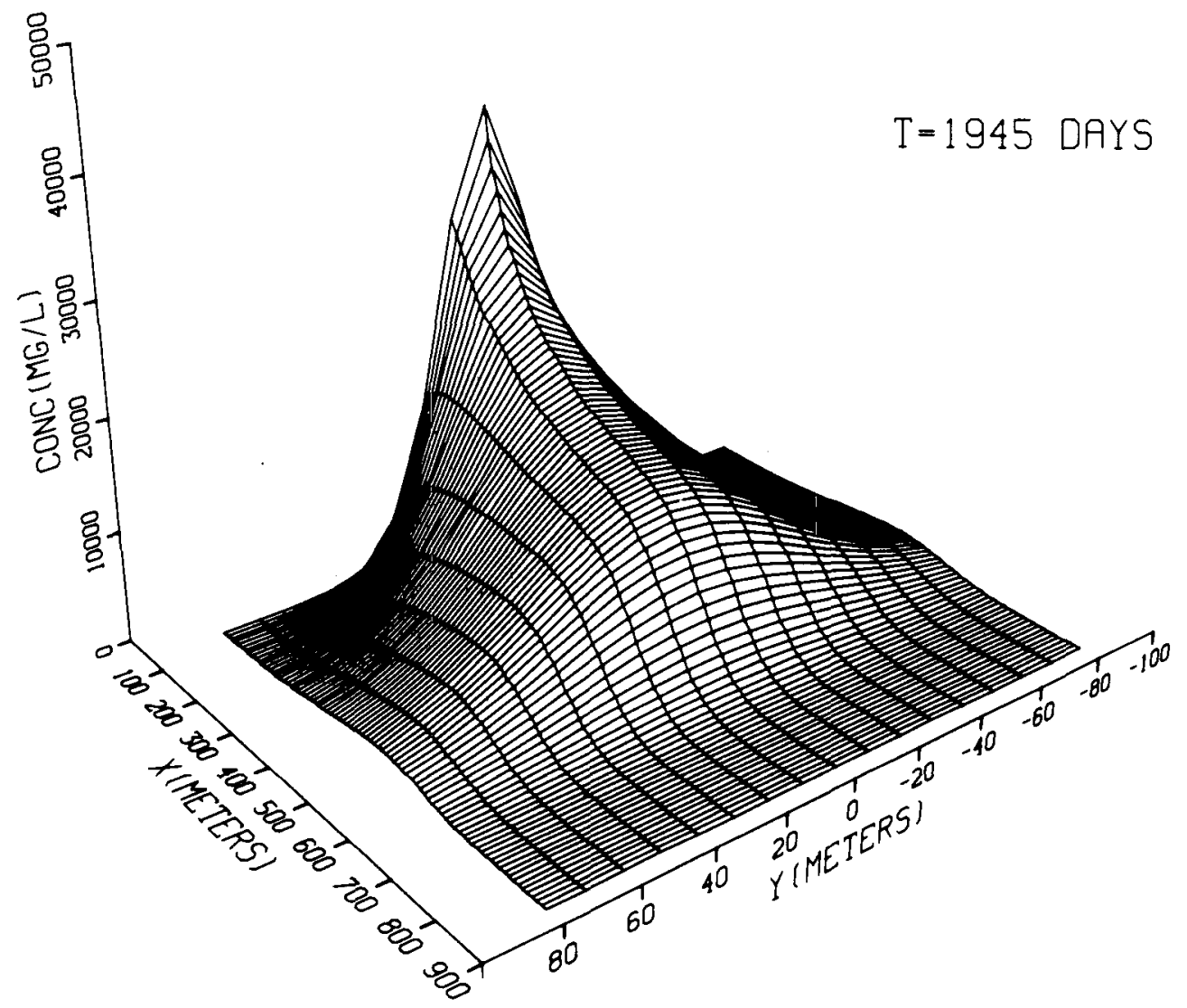

Figure 4. Brine concentration 1945 days after a continuous release directly into the aquifer.

\section{Discussion}

The two examples presented in this appendix examine isolated incidences of pollutant releases. Considering the number of wells in a typical oil field, the potential for surface spills, and the amount of wastes requiring disposal, the occurrence of more than one such pollutant release in a field is not an unrealistic estimate.

Time is an additional factor which is crucial to the issue of groundwater contamination. Groundwater generally has a very low velocity; consequently, it could take many years before contamination from a pollutant release is detected and halted. It would then take many years before transport, dilution, dispersion, absorption, and decay reduce the pollutant concentration to acceptable levels. In addition, aquifer rehabilitation requires very costly and sophisticated technologies, and time spans which exceed by many years the time it took to discover that contamination had occurred.

With regard to EOR production in the future, a shift might occur to a large percentage of smaller, independent producers who have neither the financial nor the technical resources to ensure compliance with underground injection control regulations. This represents a substantial risk to the quality of groundwater from increased EOR. 
1. Potential Environmental Consequences of Tertiary 0il Recovery, Energy Resources Co., Cambridge, MA., for EPA, Ju1y 1976.

2. J. Bear, Dynamics of Fluids in Porous Media, American Elsevier, Inc., New York, 1972.

3. J.L. Wilson and P.J. Miller, Two-dimensional plume in uniform groundwater flow, ASCE, J. Hydraul. Div. 104, HY4, 503-14 (1978).

4. R.B. Codell, Discussion of two-dimensional plume in uniform groundwater flow, ASCE, J. Hydraul. Div. 104, HY12, 1682-3 (1978).

5. M.S. Hantush, Analysis of data from pumping tests in leaky aquifer, Trans. Am. Geophys. Union 37, No. 6, 702-714 (1956).

6. M.S. Hantush, Hydraulics of Wells, Adv. Hydrosci., 1, 282-432 (1964).

7. Quality Criteria for Water, EPA-440/9-76-023, EPA, Washington, DC, 1976.

8. Water Quality Criteria, National Technical Advisory Committee Report, Federal Water Pollution Control Administration, GPO, 1968.

9. Planning Workshops to Develop Recommendations for a Groundwater Protection Strategy, Appendices, EPA, Washington, DC, June 1980.

10. Oklahoma Geologic Survey, Reconnaissance of the Water Resources of the Enid Quadrangle North-Central Oklahoma, Hydrologic Atlas 7, The University of Oklahoma, Norman, Oklahoma, 1980.

11. Groundwater Records for Northeastern Oklahoma, Part 1 - Records of We11s, Test-holes and Springs, Open File Report, USGS, March 1976.

12. Groundwater Records for Eastern Oklahoma, Part 2-Water-Quality Records for Wells, Test-Holes, and Springs, Open-File Report 78-357, USGS, May 1978.

13. R.A. Freeze and J.A. Cherry, Groundwater, Prentice-Ha11, Inc., Englewood Cliffs, NJ, 1979.

14. K. Summers, S. Gherini, and C. Chen, Methodology to Evaluate the Potential for Groundwater Pollution from Geothermal Fluid Releases, TetraTech, Inc., for EPA, EPA-600/7-8-117, August 1980 . 